HYDRODYNAMICS OF SUCTION FEEDING IN FISH

CENTRALE LANOBOUWCATALOGUS

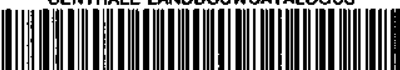

000000866232 
Promotor: dr. J. W. M. Osse, hoogleraar in de algemene dierkunde.

Co-promotor: ir. J. H. G. Verhagen, docent m.b.t. de analyse van aquatische systemen. 


\title{
HYDRODYNAMICS OF SUCTION FEEDING IN FISH
}

\author{
Proefschrift \\ ter verkrijging van de graad van \\ doctor in de landbouwwetenschappen, \\ op gezag van de rector magnificus, \\ dr. C. C. Oosterlee, \\ hoogleraar in de veeteeltwetenschap, \\ in het openbaar te verdedigen \\ op woensdag 29 juni 1983 \\ des namiddags te half drie in de aula \\ van de Landbouwhogeschool te Wageningen.
}

H. VEENMAN \& ZONEN B.V. - WAGENINGEN - 1983

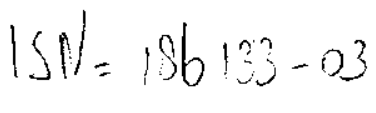




\title{
NHE: :D1, T4e.
}

\section{STELLINGEN.}

1.

In unsteady flow it is impossible to deduce the velocity of the water from the pressure. Therefore, Lauder's proposal for a model of suction feeding in fish is not valid.

\author{
Contra: Lauder (1980a, b)
}

2.

The experimental approach to determine the function of a structure by removing or severing important parts of this system as done by Liem (1970) and Lauder (1979) is comparable to the old story of studying the locomotion of the rat by successively cutting its legs. For example: Fig. 2F, p. 547 in Lauder (1979) is comparable with the case of the rat having just only one leg remained.

This crude information does not contribute to any insight in functional morphology of fish.

Contra: Liem (1970), Lauder (1979)

3.

The conclusion, based on EMG-results of recent fish, that the m. adductor operculi in the extinct palaeoniscoids should have a biphasic activity during feeding (Lauder, 1980c) is as unscientific as e.g. the conclusion that palaeoniscoids should possess a rotatable maxillary because many recent fish have such a structure.

Contra: Lauder (1980c)

4.

The model of suction feeding of fish in motion based on a sink and a parallel stream, given by Weihs (1980), is not only unrealistic because the structure of the feeding mechanism of these animals has been overlooked (e.g. the size and protrusion of the mouth aperture was not defined, the influence of the opercular valves has not been mentioned), but it includes so many hydrodynamical errors (e.g. infinite water velocity in the mouth aperture, the use of steady flow considerations, the omitting of a possibility of pushing the water, the extreme contraction of the dividing streamline when swimming is dominant) that it is invalid.

Contra: Weihs (1980)

5.

Het onderscheiden van twee assenstelsels, één aardvast en één, bewegend met de mondopening van de vis, gekombineerd met het bepalen van een punt van 
waterstilstand in de bek van de vis in een aardvast assenstelsel, is essentieel voor beschouwingen betreffende de hydrodynamica van het voedselopname-mechanisme van vissen.

zie: dit proefschrift

6.

Men kan zich niet aan de indruk onttrekken, dat in Van Hasselt (1979) een assenstelsel een stelsel is, waarin zich zeer veel assen moeten bevinden.

zie: Van Hasselt (1979)

7.

De doedelzak is een in de Oude Wereld wijd verbreid en karakteristiek volksmuziek-instrument (Baines, 1973).

Veel toonsystemen en volksmelodieen zijn zelfs terug te leiden tot de oorspronkelijk op de doedelzak gespeelde muziek (Bartók, 1967; Podnos, 1974). Het is te betreuren, dat dit instrument op veel plaatsen in onbruik is geraakt. Het feit, dat in West Europa de doedelzak in de gevestigde muziekwereld (klassiek, pop) nauwelijks serieus wordt genomen, moet als een degeneratie van de muzikale beschaving in dit gebied worden opgevat.

zie: Baines (1973), Bartók (1967), Podnos (1974)

8.

In de Macedonische en de Bulgaarse muziek komen vaak asymmetrische maatsoorten voor.

Het begrip "maatsoort" wordt bij 11/16 of hogere maatsoorten geheel bepaald door het al dan niet syncopische karakter van de muziek en verliest dan in bepaalde gevallen zijn dwingende funktie (bv. in de dansen "БАБА ГУРГА ": $11 / 16,13 / 16$ of 7/8; "ПЕТРУНО": 11/16 of 12/16 en "ЕЛЕНО MOME": $12 / 16,13 / 16$ of $7 / 8$ ).

Dit komt, doordat het verschil van $9,8.3$ of $7.7 \%$ tussen twee opeenvolgende tellen van resp. 11/16, 12/16 en 13/16 maten leidt tot een verschil in de orde van enkele procenten tussen deze maatsoorten. Dit verschil kan door de mens niet worden waargenomen.

zie: ТОДОРОВ М. (1973)

9.

De inhoud van een proefschrift geeft evenzeer een indruk van de kapaciteiten van de promovendus als van de (harte-)wensen van de promotor.

10.

De urgentie van (avond-) vergaderingen kan men gemakkelijk toetsen door voor te stellen de betreffende bijeenkomst 's morgens vroeg om half zes te houden. 


\section{1.}

Het feit, dat aan iemand, die zich heeft bekwaamd in de wiskunde en natuurwetenschappen de titel "doctor in de landbouwwetenschappen" wordt toegekend, bewijst, dat ook op akademisch niveau de ruilverkaveling heeft toegeslagen!

\section{2.}

Met het uitvoeren van zijn huidige wetenschapsbeleid bewijst de minister, dat hij lijdt aan weet-gierigheid.

\section{3.}

Vroeger was de promotie de beëindiging van de studie en het begin van een wetenschappelijke carrière. Tegenwoordig is met het behalen van de doctorstitel deze carrière in vele gevallen ten einde!

14.

Op vele laboratoria is de grijze massa omgeven door witte stof.

\section{LITERATUUR}

Baines, A. 1973. Bagpipes. Oxford Univ. Press, England.

Bartók, B. 1967. Rumanian folk music.Vol I, Martinus Nijhoff, The Hague, The Netherlands.

Hasselt M. J. F. M. van, 1979. A kinematic jaw model for the rapid wide opening and the closing of the mouth in some Labrinae (Pisces, Perciformes). Neth. J. Zool. 29 (3): pp. 352-401.

Lauder G. V. 1979. Feeding mechanics in primitive teleosts and in the halecomorph fish Amia calva. J. Zool. Lond. 187, pp. 543-578.

Lauder G. V. 1980a. Hydrodynamics of prey capture by teleost fishes. Proceedings of the second Conference on Bio-Fluid Mech., Vol 2, pp. 161-181. Plenum Press, New York.

Lauder G. V. 1980b. The suction feeding mechanism in sunfishes (Lepomis): an experimental analysis. J. Exp. Biol. 88, pp. 49-72.

Lauder G. V. 1980c. Evolution of the feeding mechanism in primitive actinopterygian fishes: A functional anatomical analysis of Polypterus, Lepisosteus and Amia. J. of Morph. 163: pp. 283-317.

Liem K. F. 1970. Comparative functional anatomy of the Nandidae (Pisces, Teleostei) Fieldiana. Zooi. 56: 1-166.

Podnos Th. H. 1974. Bagpipes and tunings. Detroit Monographs in Musicology. Inf. Coord. Inc. Detroit, USA.

ТОДОРОВ М.1973. БЪЛГАРСКА НАРОДНА МУЗИКА.

НАУКА И ИЗКУСТВО, СОФИЯ.

Weihs D. 1980. Hydrodynamics of suction feeding of fish in motion. J. fish Biol. 16, pp. 425-433.

Behorende bij het proefschrift van MeEs MulLeR:

"Hydrodynamics of suction feeding in fish."

Wageningen, 29 juni 1983 
Ik zou wel eens willen weten:

waarom zijn de zeeën zo diep?

Misschien tot geluk van de vissen, die het water zo slecht kunnen missen,

of tot meerdere glorie van God, die de wereld schiep...

Daarom zïn de zeeën zo diep!

Ik zou wel eens willen weten:

waarom zijn de mensen zo moe?

Misschien door hun jachten en jagen,

of misschien door hun tienduizend vragen!

En ze zijn al zo lang onderweg naar de vrede toe...

Daarom zijn de mensen zo moe!

Jules de Corte. 


\section{INHOUD}

1. Inleiding; tevens samenvatting in het Nederlands.

(A summary in English can be found in Chapter 2 at the end of the paper).

2. Muller M. and J. W. M. Osse.

Hydrodynamics of suction feeding in fish.

Trans. Zool. Soc. Lond., 1983 (in press).

3. Muller M., J. W. M. Osse and J. H. G. Verhagen.

A quantitative hydrodynamical model of suction feeding in fish.

J. Theor. Biol., 1982, Vol. 95, pp. 49-79.

Dankwoord

Curriculum vitae 


\section{HOOFDSTUK 1}

\section{Inleiding}

\section{Benadering van struktuur-funktie relaties.}

De funktionele morfologie onderzoekt de relaties tussen de vorm van een biologisch systeem en de funktie ervan. Bij deze studie is er vanuit gegaan, dat er een vorm-funktie relatie op grond van fysische principes aanwezig is.

Er staan drie methoden aan de funktioneel morfoloog ter beschikking om deze vorm-funktie relatie te ontrafelen: de induktieve, de experimentele en de deduktieve methode (Dullemeijer, 1974).

De induktieve methode berust op de vergelijking van vormen. In de "klassieke" morfologie werkte men bijna uitsluitend volgens deze methode. Later (na de tweede wereldoorlog) werd dit in toenemende mate aangevuld met het doen van observaties en het uitvoeren van experimenten aan levende dieren.

Het in dit proefschrift beschreven werk is voornamelijk gebaseerd op de deduktieve methode: het maken van een fysisch model. In dit model zijn de essenties van het biologische systeem geabstraheerd tot een zo gering mogelijk aantal parameters.

Het model moet inzicht geven in de wijze, waarop het systeem funktioneert door o.m. de parameters en hun relatieve invloed weer te geven. Als dit inzicht eenmaal verkregen is en het model m.b.v. experimentele gegevens is getoetst, dan kunnen door variatie van de parameters ook niet in de natuur bestaande of alleen fossiel bekende vormen gesimuleerd worden. Op deze wijze is het mogelijk om vorm en funktie causaal met elkaar in verband te brengen; "causaal" wil hier zeggen, dat op grond van een fysische oorzaak, via het mechanisme van natuurlijke selektie, een bepaalde vorm het gevolg is van die fysische oorzaak. Dit wordt nog nader toegelicht in paragraaf 3.

Door deze kwantitatieve benadering hoopt men de enorme variatie, die er aan levende en uitgestorven vormen bestaat te kunnen verklaren als aanpassingen aan verschillende funkties. Dan wordt ook het begrip "adaptatie" méér dan een biologisch dogma, omdat het dan mogelijk is om te bepalen in welk opzicht en in welke mate een organisme geadapteerd is.

In het Cambrium (500 miljoen jaar geleden) vindt men reeds fossielen van een groot aantal typen ongewervelde dieren, vaak in een vorm, die niet zoveel verschilt van de recente vormen. Een opmerkelijk voorbeeld hiervan is de fauna van de "Burgess shale" (Morris, 1979) uit het Midden Cambrium (530 miljoen jaar oud). Hierin bevinden zich, naast andere evertebraten, fossielen van dieren (Pikaia), die een grote overeenkomst vertonen met de recente Cephalochordata (lancetvisjes: ongewervelde verwanten van de vertebraten). 
De vertebraten zelf zijn nog niet aanwezig in het Cambrium. Zij verschijnen pas in het Ordovicium (de Ostracodermi; zie Moy-Thomas and Miles, 1971) en hun evolutie kan tamelijk goed gerekonstrueerd worden m.b.v. de gevonden fossielen. Daarbij is het opvallend, dat het branchiale apparaat (de kieuwbogen) een voortdurende modificatie heeft ondergaan, van een filter-apparaat in lagere vertebraten tot diverse funkties, zoals bijten, kauwen, en zelfs geluidsproduktie en -perceptie bij landdieren. Ook andere funkties, zoals ademhaling en osmoregulatie worden door dit apparaat vervuld.

\section{Voedselopname bij vissen.}

De vissen vormen met hun ca. 20.000 recente soorten (Nelson, 1976) de grootste groep van de vertebraten. Bij deze dieren vinden we opvallende vorm-variaties in de kop.

Ongeveer de helft van het recente aantal soorten vissen verkrijgt zijn prooi door zuigende voedselopname. Deze voedselopname, een vitale funktie, vindt meestal zeer snel plaats (in minder dan 100 msek.). In deze tijd expandeert en komprimeert de vis de kop. Dit gaat vaak gepaard met zwembewegingen en een vooruitschuiven van de kaken (protrusie). Op een bepaald moment tijdens dit zuigproces gaan de kleppen, gevormd door kieuwdeksels en branchiostegaal-membranen open. In de meeste gevallen stroomt het aangezogen water weg naar caudaal

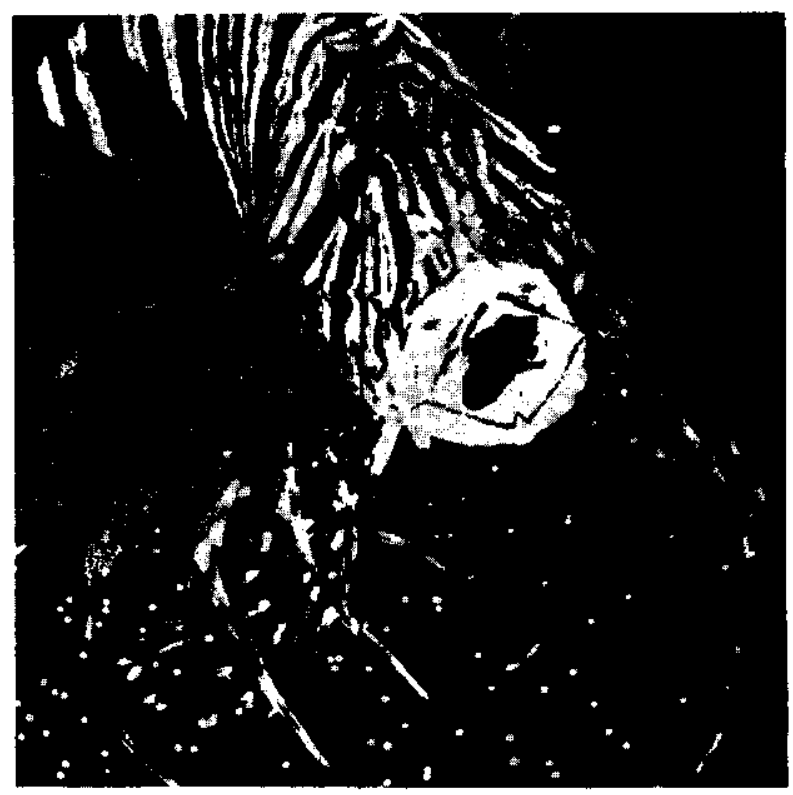

Fig. 1. Rostraal aanzicht van een koraalduivel (Pterois). Dit is een beeld van een snelle film, opgenomen met 400 beelden/sek. Door de protrusie van de kaken is een zuigbuis gevormd. De expansie van de kop begint op gang te komen, ca. 10 msek. na de start van het zuigproces. 
door de gevormde operculaire spleten. Osse (1969) leidde uit elektromyografische (EMG-) resultaten af, dat bij zo'n snelle zuigbeweging grote mechanische belastingen worden uitgeoefend op de kop en de aktieve spieren.

Ook fysische argumenten kunnen hiervoor worden aangedragen. De dichtheid van water is van dezelfde orde van grootte als de dichtheid van de vis. Dit betekent, dat ook de krachten, die nodig zijn om een zelfde volume water te versnellen als het volume van de vis, vergelijkbaar van grootte zijn.

Bijvoorbeeld: stel een vis zuigt $0.1 \mathrm{~kg}$. water op in $10 \mathrm{msek}$. met een snelheid van $10 \mathrm{~m} / \mathrm{sek}$. De versnelling is dan $1000 \mathrm{~m} / \mathrm{sek}^{2}$. (100 keer de versnelling van de zwaartekracht!) en de kracht, benodigd om deze versnelling te bereiken, 100 N.

De voedselopname stelt dus hoge mechanische eisen aan de strukturen, die de bewegingen uitvoeren.

Niet de voedselopname alleen stelt echter eisen aan de kop. Voedselopname vindt in vergelijking met bv. respiratie en zwemmen met een lage frekwentie plaats. Het is te verwachten, dat deze laatstgenoemde, meer kontinu uitgeoefende funkties, mede in sterke mate de in- en uitwendige vorm van de kop bepalen. Ook andere funkties, bv. camouflage zijn in dit opzicht van belang. De aktuele kopvorm zal daarom een kompromis zijn tussen deze diverse funkties.

De bovengenoemde gegevens hebben geleid tot de vraagstelling van het in dit proefschrift beschreven onderzoek:

Welke eisen en beperkingen voor de konstruktie van het voedselopname-apparaat vloeien voort uit de fysische eigenschappen van het water? In welke mate voldoet de aangetroffen konstruktie aan deze funktie-eisen?

Deze eisen en beperkingen kunnen worden gevonden door een hydrodynamisch model te maken van het voedselopname-systeem. De konstruktie van zo'n model is mogelijk indien aan drie belangrijke voorwaarden is voldaan:

1) De wrijving kan worden verwaarloosd.

De korte duur van het zuigproces wettigt deze simplificatie.

2) De zuigende strukturen moeten bij benadering rotatiesymmetrisch zijn gedurende het relevante deel van het zuigproces.

Onderzoek d.m.v. dissektie van ca. 50 soorten vissen en cinematografisch onderzoek aan 8 soorten vissen heeft aangetoond, dat dit inderdaad het geval is.

3) De prooi kan worden opgevat als een element van het opgezogen water.

Aan deze voorwaarde is voldaan, wanneer de prooi ongeveer dezelfde dichtheid heeft als het water. Dit is voor de meeste prooien het geval. Zwembewegingen van de prooi worden daarbij (nog) niet in beschouwing genomen (zie stelling 9).

\section{Literatuur.}

Een historisch overzicht van de literatuur betreffende het onderzoek naar het voedselopname-systeem van vissen vindt|men in Osse (1969) en Osse and Muller (1980). 
Recente bijdragen zijn: Van Hasselt (1980; funktioneel morfologisch onderzoek van het protrusie-systeem bij Labridae), Pietsch (1978; voedselopname-systeem van Styleporus, (foutieve) toepassing van de wet van Poiseuille op dit systeem), Elshoud-Oldenhave (1979; voedselopname-systeem van Stizostedion), Casinos (1974; drukmetingen bij diverse Gadidae), Nyberg (1971; predator-prooi relatie bij Micropterus), Lauder (1979, 1980 b, c, 1981; voedselopname bij Lepomis, Hoplias, Lebiasina, Chalceus, Salmo, Amia, Lepisosteus en Polypterus, (foutieve) modelvorming van het zuigproces), Lauder and Liem (1981; voedselopname bij Luciocephalus), Lauder and Lanyon (1980; spanningsmetingen in het kieuwdeksel bij Lepomis m.b.v. rekstrookjes), Lauder and Norton (1980; EMG-metingen tijdens voedselopname van Lepisosteus), Lauder and Liem (1980, voedselopname bij Salvelinus), Rand and Lauder (1981; predator-prooi relatie bij Esox), Webb and Skadsen (1980; idem), Liem and Greenwood (1981, bijdrage van EMG-gegevens bij systematisch onderzoek), McLellan (1977; voedselopname bij Macrouridae) en O'Connell (1972; voedselopname bij Engraulis).

Hoewel door de meeste van deze auteurs een enorme hoeveelheid informatie is verzameld, werd de kennis omtrent het funktioneren van het voedselopnamemechanisme eerder vertroebeld dan verduidelijkt. Dit komt, omdat de geboden informatie nauwelijks kon bijdragen tot een algemene (gegeneraliseerde) beschouwing over dit mechanisme en het zuigproces.

Deze auteurs bieden vaak een diepgaande morfologische analyse, terwijl daarentegen de funktie-analyse beperkt blijft tot het geven van EMG-patronen of bewegings-kurves.

Het grootste bezwaar tegen deze werkwijze is, dat juist de gemeenschappelijke kenmerken van de struktuur uit het zicht verdwijnen, terwijl in een gegeneraliseerd model hierop juist de nadruk wordt gelegd.

Anatomische details kunnen misschien in tweede instantie in beschouwing worden genomen of zelfs direkt al verklaard worden door het model!

De bovengenoemde minutieuze anatomische beschrijving staat in schril kontrast met de beschrijving van de bewegingen, die optreden tijdens het zuigproces. Hier wordt vaak een slecht gefundeerde keuze gedaan, omdat de biologische rol van de beschouwde strukturen onbekend is. Zo wordt bv. de beweging van het water (of van de prooi) slechts in enkele gevallen beschouwd.

Een aantal auteurs vermelden de standaard-lengte van hun proefdieren niet. Hierdoor was het vaak niet mogelijk om de literatuurgegevens met het door ons gekonstrueerde model te verwerken.

Bovendien wordt het vastleggen van bewegingen, snelheden of EMG-patronen als funktie-analyse beschouwd (Liem and Greenwood, 1981). Hier is m.i. slechts sprake van een uitgebreider vorm-beschrijving, nl vorm- en aktiviteits-variaties in tijd en plaats.

Een goed voorbeeld is het verschijnsel protrusie. In het algemeen wordt door protrusie de energie in het gehele zuigsysteem geminimaliseerd. Dit is een belangrijke funktie van protrusie.

De buisvorm van een protrusie-mechanisme wordt hier causaal in verband gebracht met een funktie van dit apparaat (op basis van natuurlijke selektie). Het 
slechts vastleggen van de bewegingen van de protruderende kaken, of de aktiviteit van de betrokken spieren is geenszins een funktie-analyse!

Een nauwkeurige beschrijving van de struktuur kan op zich een interessant doel zijn. Het maken van een biofysisch model vraagt een voor velen verregaande simplificatie van deze struktuur. Een té verregaande vereenvoudiging leidt uiteraard tot foute resultaten. Van beide werkwijzen, één teveel met het accent op de morfologie (Lauder) en één teveel met het accent op de fysika (Weihs) zal ik $U$ in deze inleiding een treffend voorbeeld kunnen geven.

\section{Recente benaderingen van de vraagstelling.}

Het artikel van Schaeffer and Rosen (1961) over de verschillende adaptieve niveaus van het voedselopname-mechanisme van Actinopterygii kan beschouwd worden als de basis van het in dit proefschrift beschreven werk. In dit artikel worden deze niveaus onderscheiden en geïnterpreteerd als optimalisaties aan de bijt-funktie. Hoewel o.i. teveel aandacht aan alleen deze funktie is gegeven, betekende het een enorme stap vooruit, dat de verschillen in struktuur tussen de kaken en de m. adductor mandibulae bij Palaeoniscoidea, "Holostei", Elopomorpha, Pro-, Par-, en -Acanthopterygii causaal (zie par. 1) werden verklaard, zij het in kwalitatieve termen.

Alexander (1967) konstrueerde op grond van fotografische opnames een simpel hydrodynamisch model van prooi-opname door zuigen, gekombineerd met protrusie van de kaken. Hij voorspelde daarmee de afstand, waarvan een prooi kon worden opgezogen (ca. $25 \%$ van de koplengte). Hij nam de stroming, veroorzaakt door het opengaan van de operculaire kleppen niet in beschouwing.

Osse $(1969,1973,1976)$ gaf het belang aan van de zuigende voedselopname naast de bijtende. Hij gaf argumenten, dat de struktuur van het kieuwdeksel en die van het branchiostegaalstralen-systeem minstens van even groot belang is voor de voedselopname als de kaken. Zijn werk heeft o.a. geresulteerd in de initiatie van het hier beschreven onderzoek.

In het artikel van Nyberg (1971) over de predator-prooi relatie bij Micropterus wordt de bijdrage van translatie van de mondopening naast het zuigen onderkend. Een onderscheid tussen de bijdragen van zuigen, zwemmen en protrusie wordt gemaakt. De mogelijkheid van het voortstuwen van het water en eventueel de prooi door het zwemmen wordt genoemd. Protrusie wordt geïnterpreteerd als een optimalisatie van het voedselopname-systeem. Hoewel al deze aspekten kwalitatief worden behandeld, moet dit artikel als een belangrijke bijdrage aan het onderzoek van het voedselopname-mechanisme worden beschouwd.

Lauder (1980a, b) trachtte via de experimentele methode (bewegingsanalyse, drukmeting) een model te maken van de zuigende voedselopname. Dit model is echter gebaseerd op dedukties over de watersnelheid (grootte en richting) vanuit de gemeten drukkurves. Omdat in instationaire stroming, zoals die tijdens het zuigen aanwezig is, zowel de versnelling als de snelheid van het water bijdraagt tot de druk, zijn de genoemde dedukties inkorrekt. Bovendien is er sprake 
van een foutieve menging van de deduktieve en de experimentele methode. Op grond van drukkurves wordt een model gemaakt, dat de stroming beschrijft. Deze stroming heeft echter een druk tot gevolg, zodat het model een cirkelredenering inhoudt. Op deze wijze wordt een (foutieve) ad hoc verklaring voor de gemeten verschijnselen gegeven. Van een gegeneraliseerde beschrijving van het zuigproces kan dan ook geen sprake zijn!

Weihs (1980) kombineerde een parallelstroom met een put (een punt, waarin vloeistof verdwijnt), teneinde het zwemmen en het zuigen in één model te kombineren. In dit model wordt echter te weinig aandacht aan de morfologie van het voedselopname-systeem en aan het zuigproces zelf geschonken.

In een put is de watersnelheid oneindig hoog. Weihs legt deze put in het belangrijkste punt van het te beschouwen stromingsveld $\mathbf{n l}$. de mondopening. Deze kan dan ook moeilijk gedefinieerd worden in zijn model. Alexander (1967) had deze moeilijkheid onderkend en opgelost! Daarnaast veronderstelt Weihs, dat de stroming stationair is. Tijdens een zuigproces, waarin het water in ca. 10-100 msek. van 0 tot $10 \mathrm{~m} / \mathrm{sek}$. wordt versneld, is dit niet het geval. Ook wordt het effekt van het openen van de operculaire kleppen over het hoofd gezien. In werkelijkheid wordt door openen een vergroting van het totale opgenomen volume water bereikt. Bij de forel (Salmo) is een vijfvoudige vergroting gemeten door Van Leeuwen (in prep.).

Het belangrijkste echter, wat Weihs over het hoofd heeft gezien, heeft direkt betrekking op het onderwerp van zijn artikel zèlf nl. de kombinatie van translatie en zuigen. Wanneer in zijn model het zwemmen domineert, dan kontraheert de delende stroomlijn tot de lengte-as en kan de prooi niet worden gevangen. Bij vele vissen (o.a. Salmo, Stizostedion, Esox, maar ook bv. Entelurus) draagt translatie van de mondopening juist belangrijk bij tot het opnemen van de prooi. Verder is het effekt, dat een vis zichzelf vooruitzuigt, niet in beschouwing genomen, evenmin als de protrusie. Zoals geschreven, had Nyberg (1971) al deze effekten reeds genoemd.

Uit het bovenstaande is het duidelijk, dat het model van Weihs geen bijdrage levert tot de kennis van het voedselopname-mechanisme bij vissen!

\section{De opzet van het model.}

Het in dit proefschrift beschreven onderzoek kan worden verdeeld in een konstruktie-procedure door simplificatie, uitgaande van een prooi-zuigende vis tot een hydrodynamisch model hiervan. Daarna volgt een mathematische beschrijving van het model (tot in details uitgewerkt in hoofstuk 3), toetsing van het model d.m.v. experimenten en toepassing van het model op diverse systemen van prooi-opname m.b.v. modelsimulaties.

Zoals beschreven, zuigt een vis zijn prooi op in zeer korte tijd en is de stroming instationair. De wrijvingsloosheid van de stroming en de rotatie-symmetrie van de bek zijn op zich hydrodynamische optimalisaties. Aangezien de kieuwen tijdens het zuigproces per boog samengevouwen zijn, is de invloed hiervan ver- 
waarloosd. Door het openen van de operculaire kleppen kunnen de hydrodynamische kondities op dat moment rigoreus gewijzigd worden, wat een grote flexibiliteit van het voedselopname-systeem impliceert. Het model bevat al deze aspekten. Tevens wordt een scherp onderscheid gemaakt tussen beschouwingen in een aardvast en in een vis-vast assenstelsel.

Het instationaire karakter van de stroming verdient hier enige aandacht. $\mathrm{Bij}$ dit type stroming spelen zowel de versnelling als de snelheid van het water een belangrijke rol.

Dit impliceert, dat water niet altijd van hoge naar lage druk stroomt, maar dat het kan bewegen tegen een drukgradiënt in.

In een versnellend systeem treden traagheidskrachten op. Deze krachten kunnen tijdens het zuigen van de vis als een positieve versnellingsdruk in de operculaire holte worden gemeten. De onmogelijkheid van het afleiden van de watersnelheid uit de druk, wanneer de stroming instationair is, is reeds genoemd.

Een vis zuigt tijdens het vangen van een prooi niet alleen water aan, hij zuigt zichzelf ook vooruit. Deze translatie wordt aangevuld door zwemmen en door vinbewegingen (bv. opduwen vanaf de bodem bij Uranoscopus). Ook protrusie van de kaken draagt bij tot de translatie van de mondopening.

Het is daarom noodzakelijk een onderscheid te maken tussen een aardvast assenstelsel en een assenstelsel, meebewegend met de mondopening. Predator-prooi relaties moeten bij voorkeur worden beschouwd in het bewegende assenstelsel, krachtenbeschouwingen (drukken) moeten in het aardvaste assenstelsel plaats vinden. Hoewel het bijzonder belangrijk is om de beweging van het water en de vis konsekwent in één assenstelsel te houden, is dit niet altijd even gemakkelijk. Vooral bij het bekijken van films ontstaat snel de neiging om het water naast de vis t.o.v. het aardvaste stelsel en de stroming vóór de vis t.o.v. het bewegende stelsel te beschouwen.

De stroming vóór de mondopening is in het model ingebouwd door de mondopening te beschouwen als een circulair wervelfilament (ringwervel). De stroming van deze wervel wordt dus alleen vóór de mondopening beschouwd. De sterkte van de wervel wordt bepaald uit de stroming, opgewekt door expansie en kompressie van de kop, zwemmen en protrusie.

De voorwaartse translatie van de mondopening in het aardvaste assenstelsel heeft in het bewegende stelsel een superpositie van de wervel en een parallelstroom tot gevolg.

Wanneer echter het zuigen het zwemmen niet "bijhoudt", treedt stuwing op. In dat geval keert de wervel om. De kontinue balans tussen translatie en zuigen tijdens het voedselopname-proces is in het model mede in beschouwing genomen.

Beschouw een cylindervormig, radiaal expanderend profiel, dat aan één zijde gesloten is. Dit profiel zal zichzelf in een aardvast assenstelsel "vooruitzuigen" (in de richting van de open zijde). De watersnelheid aan de gesloten zijde is dus naar voren gericht, terwijl deze snelheid aan de open zijde naar achteren is gericht. Halverwege het profiel is de watersnelheid nul. Dit punt van waterstilstand voert zelf wél een beweging uit (in het aardvaste stelsel). 


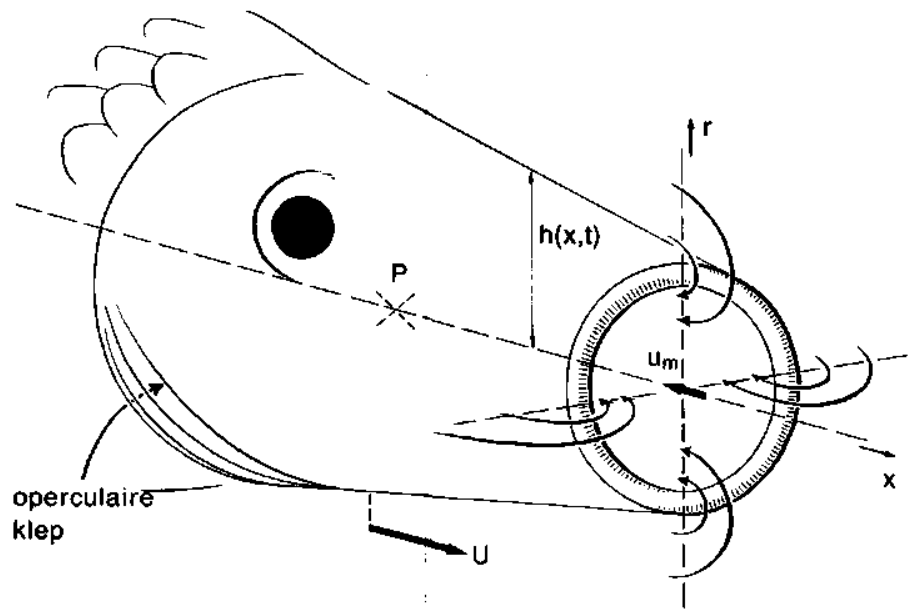

Fig. 2. Een kegelvormig model van de zuigende vissekop, $h(x, t)$, weergegeven in een aardvast assenstelsel en op één bepaald moment. De mondopening wordt gevormd door een ringwervel. De snelheid in deze opening is $u_{m}$. De snelheid van het profiel zelf is $U$. Het punt van waterstilstand is aangegeven door $P$. De operculaire klep gaat op $t=\tau$ open.

In de vis zal ook een dergelijk punt van stilstand optreden. De plaats van dit punt is van essentieel belang voor het zuigproces. De door Van Leeuwen (in prep.) uitgevoerde studie als vervolg op het hier gepresenteerde werk geeft dit belang kwantitatief aan.

\section{Experimentele toetsing.}

Met het model is het mogelijk om de watersnelheid en de druk als funktie van tijd en plaats in en bij het profiel te berekenen, indien de beweging van het model wordt voorgeschreven.

Het toetsen van het model kan gebeuren, door de bewegingen van de vis in het model in te voeren, de watersnelheid en de druk uit te rekenen en vervolgens deze grootheden experimenteel te checken. In het nu volgende zal deze procedure verder worden toegelicht.

De bewegingsfunkties kan men bepalen door het analyseren van filmbeelden (400 bld/sek.), die van een zuigende vis zijn gemaakt (van lateraal of frontaal en m.b.v. een spiegel onder 45 graden van ventraal). De op deze wijze gemeten bewegingskurves kunnen worden aangepast met een funktie, die de bewegingen zo goed mogelijk beschrijft. Het is echter gebleken, dat de beweging niet zó nauwkeurig kan worden gemeten, dat op grond van deze gegevens de druk kan worden voorspeld.

Drukmeting blijft dus noodzakelijk om het zuigproces nauwkeurig vast te leggen in de parameters van het model. 
Het meten van de druk in een instationair stromingsveld stuit op enorme problemen. Hoewel er tegenwoordig catheter-tip-pressure-transducers worden gemaakt met zeer kleine afmetingen (ca. $1 \mathrm{~mm}$. tip-diameter) en met een voldoende bandbreedte $(5-10 \mathrm{kHz})$, is de invloed van de verstoring van de stroming dichtbij de transducer op de gemeten druk groot. Een uitgebreid onderzoek naar drukmeting gedurende het zuigproces van vissen is samengevat in hoofdstuk 2 en wordt apart gepubliceerd (Van Leeuwen and Muller, in prep.).

De druk blijkt te zijn opgebouwd uit zes verschillende komponenten: 1) een druk t.g.v. de versnelling, die het water door het zuigen krijgt, 2) een druk t.g.v. de snelheid van het water, 3) een versnellingsdruk t.g.v. translatie van het profiel, 4) een mengterm, 5) en 6) de snelheids- resp. versnellingsdruk t.g.v. het uitwendige stromingsveld.

Afhankelijk van de beweging (radiaal en axiaal) van de vis bepalen deze termen de grootte van de druk als funktie van tijd en plaats, in en vóór de bek van de vis. Het is daarbij verrassend, dat de drukverdeling in de bek van de vis een zeer grillig verloop heeft als funktie van de tijd en van de soort beweging. Soms wordt in de buccale holte een lagere druk bereikt dan operculair, enkele millisekonden later kan het omgekeerde het geval zijn. In beide gevallen kan er tóch water in caudale richting stromen. Deze verschijnselen, die een gevolg zijn van de instationariteit van de stroming, hebben Lauder $(1980 \mathrm{a}, \mathrm{b})$ op een dwaalspoor gebracht bij de konstruktie van zijn model.

Visualisatie van de stroming vóór de mond en achter de kieuwspleten werd uitgevoerd d.m.v. ongeëxpandeerde polystyreenbolletjes met een diameter van 0.5-1.0 mm. Het snelheidsverschil tussen de bolletjes en het water is in de orde van $0.1 \%$. Pieksnelheden kunnen echter niet worden gemeten met deze techniek. Daarom zijn ook watersnelheids-metingen m.b.v. een hot-film-anemometer uitgevoerd. Hierdoor is het mogelijk om op één plaats watersnelheden te meten met een nauwkeurigheid van $1 \%$ en een bandbreedte van $10 \mathrm{kHz}$.

De snelheid van de stroming kan nauwkeurig (fout $<2 \%$ ) worden berekend wanneer de operculaire klep gesloten is.

Bij geopende klep zijn berekeningen mogelijk, maar de randvoorwaarde voor deze berekeningen (een snelheid of druk) is moeilijk te bepalen. Predicties m.b.v. het model bij open klep zijn daarom beperkt te geven.

Film-analyse werd bij acht soorten vissen uitgevoerd: de moddersnoek (Amia), de forel (Salmo), de snoekbaars (Stizostedion), de kabeljauw (Gadus), de zeenaald (Entelurus), de bot (Platichthys), de sterrenkijker (Uranoscopus) en de koraalduivel (Pterois). In totaal werden ca. 100 happen geanalyseerd.

Hot-film-anemometrie werd toegepast bij de forel (Salmo), stromings-analyse met polystyreen-bolletjes werd uitgevoerd bij de koraalduivel (Pterois).

Drukmetingen werden uitgevoerd bij Salmo, Esox, Amia en Gadus (Van Leeuwen and Muller, in prep.). 


\section{Konklusies.}

Wat kan men op grond van deze fysische gegevens nu konkluderen over de vorm-funktie relatie? Op de eerste plaats is het mogelijk om diverse voedselopname-typen te onderscheiden op grond van het tijdstip van openen van de operculaire klep en de impuls (energie), die aan het water en de vis wordt gegeven.

Als primitiefste type kan het filteren van voedsel worden beschouwd, zoals dit bij de ongewervelde chordaten, maar ook bv. bij de ansjovis (Engraulis) voorkomt (O'Connell, 1972).

Filteren van voedsel door met open bek en uitgespreide kieuwzeef door het water te zwemmen is mogelijk het uitgangspunt geweest voor een predatoire, zuigende voedselopname (Miles, 1971). Het opzuigen van de prooi werd mogelijk door de ontwikkeling van de operculaire klep, die een initiële caudale afsluiting kon bewerkstelligen. Wanneer deze klep niet sterk ontwikkeld is, is een kombinatie van zwemmen en zuigen noodzakelijk (zoals bij veel Pro-acanthopterygii, bv. Salmo). Hoewel bij Salmo de prooi stilstaat (impuls $=0$ ), wordt aan het lichaam en het water, caudaal daarvan een grote impuls gegeven. Bovendien is dit type voedselopname beperkt tot het open water en is zuigen uit hoeken of van een substraat niet mogelijk. Deze mogelijkheid ontstaat bij een verdere ontwikkeling van de klep, zoals bij Paracanthopterygii (bv. Gadus). Bij het zuigen uit hoeken moet dan echter een relatief groot volume water worden verplaatst.

Bij Palaeoniscoidea vindt men een niet-roteerbaar maxillare. Bij de Halecostomi wordt dit element roteerbaar en bewerkstelligt een afsluiting van de mondhoeken tijdens het zuigen. Hierdoor wordt de zuigkapaciteit vergroot.

Het meest geavanceerde voedselopname-apparaat wordt gevonden bij de Acanthopterygii, die een protrusie-mechanisme bezitten.

Aan de hierboven genoemde typen van zuigen wordt dan een nieuw type toegevoegd, waarbij naast een zeer snelle zuigbeweging (vaak van relatief geringe amplitude) het vormen van een zuigbuis door vooruitschuiving van de kaken plaatsvindt (bv. Pterois). Op deze wijze wordt de impuls van het totale systeem zeer laag gehouden en is deze beweging daarom energetisch zeer voordelig. Naast deze algemene lijn van de ontwikkeling van het zuigapparaat zijn verregaande specialisaties mogelijk. Een voorbeeld daarvan is de zeenaald (Entelu$r u s$ ), die tijdens het zuigen de snuit dorso-roteert.

Al deze typen zuigen leggen ook specifieke eisen op aan de stroomlijn van de vis. Ook tijdens voedselopname is het belangrijk, dat de vis gestroomlijnd is. Dit komt de snelheid van de beweging ten goede, zodat de kans op ontsnapping van de prooi wordt geminimaliseerd.

Zo vraagt zuigen plus zwemmen een zeer gestroomlijnd lichaam, zuigen plus protrusie daarentegen niet.

Ook m.b.t. de konstruktie van de kop kunnen m.b.v. het model konklusies worden getrokken. De kieuwen hebben de vorm van een hydrofoil en zijn gesitueerd langs de stroomlijnen.

Hierdoor wordt een zo ongestoord mogelijke stroming en een geringe weerstand tijdens het zuigen gewaarborgd. 
Ook de schoudergordel en de wand van de bek (lippen, suspensoria, kieuwdeksels) zijn gestroomlijnd. De lippen bevatten bovendien de wervel-singulariteit.

Wanneer men modelsimulaties uitvoert met toenemende lengte van het profiel en alle andere parameters konstant houdt, dan neemt de grootte van de inwendige druk enorm toe. Hieruit kan men afleiden, dat de grootst mogelijke lengte van de kop van een prooi-zuigende vis ongeveer $40 \mathrm{~cm}$. moet zijn. Boven een dergelijke lengte moeten andere voedselopname-typen, bv. filteren, worden toegepast.

In een reeks van vissen met toenemende beklengte kan men steeds groter wordende drukken en dus konstruktie-verstevigingen verwachten. Bij de meeste vissen wordt het effekt van de grotere beklengte op de druk echter gekompenseerd door een langzamer beweging. Kremers and Van Leeuwen (in prep.) hebben dit aangetoond voor de snoek (Esox).

Bij de Syngnathiformes (zeenaalden), evenwel, is het verschil in beklengte tussen diverse soorten zo extreem, dat konstruktieverschillen worden waargenomen.

Een lange bek gaat bij deze dieren inderdaad samen met een steviger konstruktie (bv. bolle kieuwdeksels, richels als versterking van beenelementen).

Het is wellicht mogelijk om de resultaten van dit onderzoek te kombineren met oecologisch onderzoek bv. naar secundaire produktie in meren (Barel, 1980).

Ook kan m.b.v. de onderhavige benadering inzicht worden verkregen in de voedselopname van jonge vissen. Zelfs herbivore vissen (bv. cypriniden) beginnen hun leven als prooi-zuigende predator! Wanneer hierover meer gegevens kunnen worden verkregen is het wellicht mogelijk om de hoge sterfte bij deze dieren te bestrijden (bv. in teeltsystemen).

Tenslotte wil ik nog de toepassing van deze studie noemen, wanneer er sprake is van predatie en/of konkurrentie tussen soorten, zoals onlangs is aangetoond voor bv. haring en kabeljauw (Daan, 1976, 1980).

\section{LITERATUUR}

Alexander, R. McN. 1967. The functions and mechanisms of the protrusible jaws of some acanthopterygian fish J. Zool. Lond. 151, pp. 43-64.

Barel, C. D. N. 1980. Vergelijkend biologisch onderzoek aan cichliden. (In Dutch). Vakbl. Biol. 12,60. pp. 228-239.

Casinos, A. 1974. Registres de la chute de pression de la cavité buccale chez quelques Gadiformes de nos côtes. XXIV-e Congr. Ass.-Plen. de Monaco, pp. 1-4.

Daan, N. 1976. Some preliminary investigations into predation on fish eggs and larvae in the southern north sea. Int. Counc. Expl. Sea. C.M. 1976/L: 15, pp. 2-11.

Daan, N. 1980. A review of replacement of depleted stocks by other species and the mechanisms underlying such replacement. Rapp. P.-v. Réun. Cons. int. Explor. Mer, 177: pp. 405-421.

Dullemeyer, P. 1974. Concepts and approaches in animal morphology. V. Gorkum, Assen, the Netherlands. 
Elshoud-Oldenhave, M. J. W. 1979. Prey Capture in the Pike-Perch, Stizostedion lucioperca (Teleostei, Percidae): A Structural and Functional Analysis. Zoomorphology 93, pp. 1-32.

Hasselt, M. J. F. M. van 1980. Relationship between movement and structure in the jaw apparatus of some Labrinae (Pisces, Perciformes). Thesis, RU-Leiden, The Netherlands.

Kremers, J. J. M. and Leeuwen, J. L. van in prep. The influence of growth on the prey capture mechanism of the pike (Esox lucius).

Lauder, G. V. 1979. Feeding mechanics in primitive teleosts and in the halecomorph fish Amia calva. J. Zool. Lond. 187, pp. 543-578.

Lauder, G. V. 1980a. Hydrodynamics of prey capture by teleost fishes. Proceedings of the second Conference on Bio-Fluid Mech., Vol 2, pp.161-181. Plenum Press, New York.

Lauder, G. V. 1980b. The suction feeding mechanism in sunfishes (Lepomis): an experimental analysis. J. Exp. Biol. 88, pp. 49-72.

Lauder, G. V. 1980c. Evolution of the feeding mechanism in primitive actinopterygian fishes: A functional anatomical analysis of Polypterus, Lepisosteus and Amia. J. of Morph. 163: pp. 283-317.

Lauder, G. V. 1981. Intraspecific Functional Repertoires in the Feeding Mechanism of the Characoid Fishes Lebiasina, Hoplias and Chalceus. Copeia (1) pp. 154-168.

Lauder, G. V. and Liem, K. F. 1980. The feeding mechanism and cephalic myology of Salvelinus fontinalis: form, function and evolutionary significance. In Charrs. Ed. by E. K. Balon. Dr. W. Junk bv publishers. The Hague. The Netherlands. pp. 365-390.

Lauder, G.V. and Lanyon, L. E. 1980. Functional anatomy of feeding in the bluegill sunfish, Lepomis macrochirus: in vivo measurement of bone strain. J. Exp. Biol. 84, pp. 33-55.

Lauder, G. V. and Liem, K. F. 1981. Prey capture by Luciocephalus pulcher: implications for models of jaw protrusion in teleost fishes. Env. Biol. Fish. Vol. 6, No. 3/4, pp. 257-268.

Lauder, G. V. and Norton, S. F. 1980. Asymmetrical muscle activity during feeding in the gar, Lepisosteus oculatus. J. Exp. Biol. 84, pp. 17-32.

Liem, K. F. and Greenwood, P. H. 1981. A Functional Approach to the Phylogeny of the Pharyngognath Teleosts. Am. Zool., 21: 83-101.

Leeuwen, J. L. van in prep. A quantitative study of flow in prey capture by rainbow trout, with general consideration of the actinopterygian feeding mechanism.

Leeuwen, J. L. van and Muller, M. in prep. The recording and interpretation of pressures in prey sucking fish.

McLellan, T. 1977. Feeding strategies of the macrourids. Deep-Sea Research, Vol. 24, pp. 1019-1036.

Moy-Thomas, R. A. and Miles, R. S. 1971. Palaeozoic fishes. London. Chapman and Hall; Philadelphia: Saunders. $259 \mathrm{pp}$.

Morris, S. C. 1979. The Burgess Shale (Middle Cambrian Fauna). Ann. Rev. of Ecol. and Syst. Vol. 10, pp. 327-351.

Nelson, J. S. 1976. Fishes of the world. John Wiley \& Sons, New York, London. 416 pp.

Nyberg, D. W. 1971. Prey Capture in the Largemouth Bass. The Am. Midl. Naturalist, 86 (1), pp. 128-144.

O'Connell, C. P. 1972. The interrelation of biting and filtering in the feeding activity of the northern anchovy (Engraulis mordax). J. Fish. Res. Bd. Can. 29, pp. 285-293.

Osse, J. W. M. 1969. Functional Morphology of the head of the Perch (Perca fluviatilis L.): An electromyographic study. Neth. J. of Zool. 19 (3) pp. 289-392.

Osse, J. W. M. 1973. Form and function of the branchiostegal apparatus in Amia calva. Neth. J. of Zool. 23 (3): pp. 359,360.

Osse, J. W. M. 1976. Mécanismes de la respiration et de la prise des proies chez Amia calva Linnaeus. (abstract). Rev. Trav. Inst. Pêches Marit. 40 (3 et 4): pp.701,702.

Osse, J. W. M. and Muller, M. 1980. A model of suction feeding in teleostean fishes with some implications for ventilation. In Environmental physiology of fishes. M. A. Ali, edit. NATO-ASI. Series A. Life Sciences.

Pietsch, Th. W. 1978. The feeding mechanism of Stylephorus chordatus (Teleostei: Lampridiformes). Functional and ecological implications. Copeia (2), pp. 255-262.

Rand, D. M. and Lauder, G. V. 1981. Prey capture in the chain pickerel, Esox niger: correlations between feeding and locomotor behavior. Canad. J. Zool. 59, Nr. 6, pp. 1072-1078. 
Schaeffer, B. and Rosen, D. E. 1961. Major adaptive levels in the evolution of the actinopterygian feeding mechanism. Am. Zoologist 1, pp. 187-204.

Webb, P.W. and Skadsen, J. M. 1980. Strike tactics of Esox. Can. J. Zool. 58: pp. 1462-1469.

Weihs, D. 1980. Hydrodynamics of suction feeding of fish in motion. J. Fish Biol. 16, pp. 425-433. 
HOOFDSTUK 2

Hydrodynamics of suction feeding in fish 


\title{
Hydrodynamics of suction feeding in fish
}

\author{
M. Muller and J. W. M. Osse. \\ Department of Experimental Animal Morphology and Cell Biology, \\ Agricultural University, ZODIAC, Marijkeweg 40, \\ 6709 PG Wageningen, The Netherlands.
}

\begin{abstract}
KEYWORDS
feeding patterns of fish, fish evolution, fish head morphology, flow visualization, gill cover, hydrodynamics, model of feeding, parameter variation and feeding, pressure in fish, streamline in fish, suction feeding, swimming of fish, watervelocity.
\end{abstract}

\section{SYNOPSIS}

The field of flow during suction feeding of eight species of teleosts belonging to different divisions in that group was studied using high-speed movies, flow visualization techniques, velocity- and pressure-transducers. A hydrodynamic model was constructed featuring the interrelation between shape and movement of mouth and gill cover, the moment of prey swallowing, the influence of predator translation on the flow, the influence of the time of opening of the opercular- and branchiostegal valves and the unsteady nature of the generated flow.

Two coordinate systems, one from the observer and earth-bound and one moving with the predator, are necessary to connect observations with the flow as experienced by the predator.

The distinction of a point of zero flow in the mouth cavity greatly facilitated the construction of streamline patterns.

The model is discussed with respect to its simplifying approximations and its application by checking predictions with experimental results. A series of feeding types is described differing in shape of the flow, time of valve opening, relative contribution of forward motion and presence or absence of jaw protrusion. The streamlining of the mouth cavity, pectoral girdle and gills is explained in relation to water flow during feeding. Quantitative results of model studies concerning flow velocities and pressure-distribution allow qualitative predictions concerning the effects of isometric and allometric growth.

Changes in fish head construction during evolution, previously explained in terms of the biting function, are also interpreted as improvements of the hydrodynamical efficiency of suction feeding. An evaluation of existing literature on suction feeding is presented. 


\section{CONTENTS.}

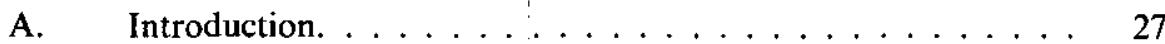

B. Materials and methods. . . . . . . . . . . . . . 29

B1. The fishes. ................... 29

B2. Film and motion analysis. .............. 29

B3. Flow visualization and velocity measurements. . . . . . . . 30

B4. Pressure measurements. . . . . . . . . . . . . . . 30

C. Construction of the model. . . . . . . . . . . 32

C1. Limitations of model studies. . . . . . . . . . . . 32

C2. Unsteady flow. . . . . . . . . . . . . . . . 33

C3. Simplifying approximations for the suction process. . . . . . 34

C3.1 Friction can be neglected. . . . . . . . . . . . . 34

C3.2 Rotational symmetry; profile form chosen. . . . . . . . . . 42

C3.3 The prey is an element of the sucked water. . . . . . . . . 46

C3.4 The branchiostegal and opercular valves are represented by a "valve" at one side of the profile. . . . . . . . . . . . . 47

C3.5 Flow description; from a two-dimensional to an uni-dimensional approach.

C3.6 Approximations for the external flow in front of the mouth aperture and caudal of the opercular slits. . . . . . . . . 50

C3.7 The adequacy of the model after simplification. . . . . . . 52

C4. Outlines of the model. . . . . . . . . . . . . . 52

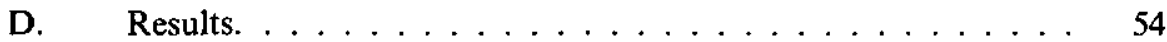

D1. Profile form and movement. ............... 54

D1.1 Definition and determination of profile excursions. . . . . . . 54

D1.2 Corrections for the shape of the profile. . . . . . . . . 60

Di.3 The opercular and branchiostegal valve. . . . . . . . . . 61

D1.3.1 Opening of the valve; consequences for fish head morphology and flow direction. . . . . . . . . . . . . . . . . 61

D1.3.2 Observed feeding types, their profile form and movement. . . . 61

D1.3.3 The construction of the gill cover as an adaptation to the type

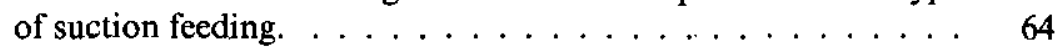

D2, Velocities; magnitude and direction. . . . . . . . . . . 64

D2.1 Cylinder with closed valve. .............. 64

D2.2 Cone with closed valve. . . . . . . . . .... 66

D2.3 Opening of the valve. ..................... 68

D2.3.1 Manipulation of the flow by opening of the valve and with open

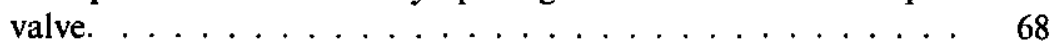

D2.3.2 Conditions for outflow from the opercular slits. . . . . . . . 70

D2.4 Velocity measurements. . . . . . . . . . . . . . . 74

D2.5 Some morphological features as determinants of the flow. . . . 74

D2:5.1 Sealing of the opercular slits. . . . . . . . . . . . . . 74

D2.5.2 Closure of the edges of the mouth aperture; protrusion. . . . . 76

D3. Velocities; the shape of the flow. ........... 77 


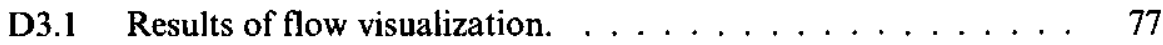

D3.2 The flow inside the profile. . . . . . . . . . . . . 79

D3.3 The flow in front of the mouth aperture. . . . . . . . 83

D3.3.1 The flow caused exclusively by suction. . . . . . . . . 83

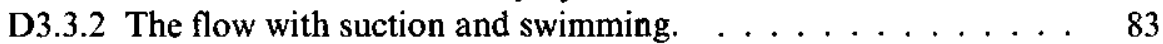

D3.3.3 The streamline of the fish. . . . . . . . . . . . . 87

D3.3.4 The flow related to the type of suction, the shape of the fish and the construction of the mouth. . . . . . . . . . . . . 89

D3.4 The flow behind the profile. . . . . . . . . . . . . 93

D4. The pressures. . . . . . . . . . . . . . 93

D4.1 The components of the pressure. . . . . . . . . 93

D4.2 The pressure as a function of the time. . . . . . . . 95

D4.3 The pressure distribution inside the mouth. . . . . . . . 97

D4.4 Pressure and fish head construction. . . . . . . . . . . . . . 99

D4.4.1 The mechanical load on the fish's head. . . . . . . . . 99

D4.4.2 The opening of the opercular and branchiostegal valve. . . . . 102

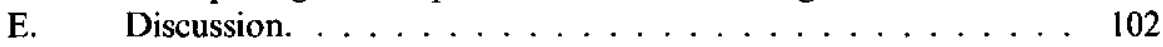

F. Acknowledgements. . . . . . . . . . . . 106

Summary. . . . . . . . . . . . . . . . . . . . . . . . 107

References. . . . . . . . . . . . . . . . . . 109

Appendix I: formula's. . . . . . . . . . . . 111

Appendix II: list of used symbols. . . . . . . . . . . 112

\section{A. Introduction.}

Following the evolutionary changes in function of jaws and visceral arches we observe adaptive modifications from a filtering device in lower chordates to a variety of functions e.g. respiration, prey suction, biting and masticating and also sound perception and -production in terrestrial types (Lessertisseur and Robineau, 1969). Major functions in fishes are feeding and respiration. As pointed out by Schaeffer and Rosen (1961) evolutionary alterations of the dermal armour, the jaws and associated muscles are mainly related to the predaceous feeding function.

However they emphasize biting, omitting the importance of the branchiostegaland opercular structures in prey suction (Osse, 1973, 1976).

Prey suction precedes biting and often no biting at all is observed in feeding fishes. It will be argued in this paper that the gill cover performs a major role in suction feeding. Its evolutionary development must be coupled with the development of protrusion. Together these changes are features to understand the further radiation of the suction feeding system.

The high mechanical loads occurring during feeding, resulting from very rapid (generally less than $100 \mathrm{msec}$ ) and forceful movements with extreme amplitudes, are the principal factors determining the construction of successive types of the feeding apparatus (Osse, 1969). 
The majority of the 20,000 recent species of Teleostei obtains its prey by suction feeding often coupled with biting and swimming. An estimate derived from Nelson (1976: p. 3) is about 12,000 species.

Feeding by suction is the most appropriate way to obtain aquatic preys due to the physical properties of water, fish and prey.

Generally mouth enlargement of an animal results both in air and in water in a suction flow. The density of air is very low compared to the animal's density and the forces due to the air flow are therefore negligible.

The density of water and fish have the same order of magnitude. A considerable force is therefore needed to accelerate the water into the opening mouth because the total volume of the ingested and moved water is equivalent to the volume of the fish.

In air a predator may approach and catch a prey without moving it by the generated air flow. In water a free swimming prey is pushed away by the flow generated when its predator approaches. This effect is avoided by swimming towards the food with permanently open mouth and opercular slits (as e.g. occurs in filtering fishes like Engraulis (O'Connell, 1972), Sarda (Fricke, 1973)), by capturing the prey by a sideward movement of the pincer like jaws (as applied by e.g. Lepisosteus (Lauder, 1980c)) and by eliminating the stagnation point at the snout tip by suction (Osse and Muller, 1980). The latter method is most frequently used in combination with swimming or protrusion (Nyberg, 1971).

Because prey suction in fish is such a widely distributed and important mechanism, we decided to study quantitatively the relation between the form of the suction mechanism and the hydrodynamical demands and limitations to which it is subjected. From these starting points a hydrodynamical model is constructed allowing variation of single parameters and their effect on other parts of the fish's head construction. In this way a series of well founded hypotheses is generated which can be tested in experiments.

Measurements of the pressures and water velocities and -accelerations occurring during prey suction provides detailed and physically defined bases to understand fish head construction.

In this paper the biological questions involving the construction of such a hydrodynamical model of suction feeding are discussed. The mathematical description of the model can be found in Muller et al. (1982). 
TABLE I. Fish species and parameters of their suction acts (from Plate 1). SL is standard length, $H$ is maximum radius of mouth aperture, $L$ is head length, Displ. is maximal displacement of mouth aperture till the moment $t_{h_{I m a x}}$, Swimm. indicates if considerable swimming occurred $(+)$, Prot. = maximum protrusion-length. Refer also to Plate 1, Fig. 11, 12.

of each individual indicated many feeding acts were analysed, in total exceeding 100.

\begin{tabular}{|c|c|c|c|c|c|c|c|c|}
\hline species & Code & $\begin{array}{l}\text { SL } \\
(\mathrm{mm})\end{array}$ & $\begin{array}{l}\mathbf{L} \\
(\mathrm{mm})\end{array}$ & $\mathrm{H}^{2} / \mathrm{L}^{2}$ & $\begin{array}{l}\text { Displ. } \\
\text { (mm) }\end{array}$ & $\begin{array}{l}\text { Prot. } \\
\text { (mm) }\end{array}$ & Swimm. & $\begin{array}{l}\text { Prey } \\
\text { capt. }\end{array}$ \\
\hline Amia calva & 200004 & 365 & 92 & 0.0378 & 17.4 & 0 & - & yes \\
\hline Salmo gairdneri & 050003 & 210 & 51 & 0.1493 & 28.8 & 0 & + & yes \\
\hline Gadus morhua & 080001 & 375 & 100 & 0.0250 & 13.6 & 0 & - & yes \\
\hline Entelurus aequoreus & 240004 & 191 & 25 & 0.0068 & 4.8 & 0 & - & (yes) \\
\hline Uranoscopus scaber & 090008 & 184 & 62 & 0.0625 & 27.1 & 2.9 & - & yes \\
\hline Pterois russelli & $033018 B$ & 138 & 40 & 0.0697 & 28.6 & 10.0 & - & $\begin{array}{l}\text { in } 1 \text { st } \\
\text { act }\end{array}$ \\
\hline Stizostedion lucioperca & 041004 & 310 & 90 & 0.0474 & 22.4 & 4.6 & + & no \\
\hline Platichthys flesus & 070027 & 315 & 71 & 0.0840 & 18.3 & 4.7 & - & yes \\
\hline
\end{tabular}

\section{B. Materials and methods.}

\section{B]. THE FISHES.}

Table I gives a survey of the animals used. They were kept in tanks of $100 \times 50 \times 50 \mathrm{~cm}$.

Large trout and cod however are in such tanks limited in their movements resulting in a higher number of unsuccesful prey captures. Care was taken to maintain proper tank temperature, $\mathrm{pH}$, water-density and nitrite content of the water. After a period of acclimatization the animals were trained from one to several weeks to feed in the light needed for filming. To obtain maximal effort of the fish at feeding they were kept rather hungry. During training the prey was moved rapidly out of the predator's path to activate the fish.

When manipulation of the fish was needed it was anaesthetized with MS $222(70-150 \mathrm{mg} /$ liter water, depending on the animal's dimensions) in order to reduce stress. Operations e.g. mounting of transducers were carried out in a shallow operating dish with circulating water. The fish was kept moist with paper tissues, the depth of anaesthesia was regulated with small amounts of double concentrated MS 222 solution. Water aerated with carbogen gas $(95 \%$ oxygen, $5 \%$ carbon dioxide) was used for irrigating the gills. In this way operations could be pursued for periods up to 5 hours.

\section{B2. FILM AND MOTION ANALYSIS.}

High speed ciné-films $(400 \mathrm{fr} / \mathrm{sec})$ of prey sucking fish were made with a Teledyne DBM 54 camera with Angenieux zoom objective $10 \times 12 \mathrm{~A}$. The fish was filmed from lateral or rostral, its ventral side was projected to the camera by a mirror at 45 degrees.

To obtain sharp images from both the lateral and the ventral side a depth of field of at least 8 $\mathrm{cm}$ was required. The combination of an exposure time of $1 / 4000 \mathrm{sec}$, a diaphragm number of 5.6-8.0 and a 250 ASA negative film (Eastman Double-X) provided the required optical solution. A battery of 24 continuous halogen light sources (each $1 \mathrm{~kW}$ ) with dichroic (red) filters provided the necessary illumination strength with a minimum of warmth generation at the fish's body.

The high illumination strength implied an unnatural situation for most fishes. Stroboscope and image intensifier within our budget are restricted to film speeds below $100 \mathrm{fr} / \mathrm{sec}$ and this is too slow to registrate suction movements with a typical duration in the order of $50 \mathrm{msec}$.

We therefore initially selected as a genus for filming Pterois (lionfish) whose habitat is also highly illuminated. Besides it is very voracious. Indeed Pterois appeared to adjust itself rapidly to the trai- 
ning but with proper chosen experimental conditions also the feeding movements of other fish species (e.g. Stizostedion and Uranoscopus) could be filmed at $400 \mathrm{fr} / \mathrm{sec}$.

Motion analysis was performed by measuring single frames on a Vanguard motion analyser (type S13). This resulted in an absolute error in the measurements of $\max .0 .5 \mathrm{~mm}$ (with an image size of about $25 \mathrm{~cm}$ ).

\section{B3. FLow Visualization and VELOCITY MEASUREMENTS.}

The flow during a suction movement was visualized by silver-plated polystyrene spheres of ca. $0.5 \mathrm{~mm}$ diameter and with a density differing less than 0.5 percent from sea water density ( 1028 $\mathrm{kg} / \mathrm{m}^{3}$ at $25^{\circ} \mathrm{C}$ ). The spheres were sucked by the fish together with the prey and could easily pass the gill arches providing also a visualization of the flow behind the opercular slits.

When the flow is a parallel stream with respect to the dimensions of a sphere, a polystyrene sphere of equal density as the water behaves like a "water-sphere" (see also C3.3). This implies that forces acting on the polystyrene sphere are equal to forces exerted on the watersphere. So, e.g. velocities and accelerations will be the same in both cases. When the densities of polystyrene- and waterspheres differ, the masses differ proportionally to the ratio of the densities and thus the forces, accelerations and velocities.

The dimensions of the spheres are very small compared to the contraction of the flow and the densities of the spheres hardly differ from the density of the water. Therefore the spheres will have the same velocities as the water.

Because the velocities are measured from the film by comparing spheres at successive frames a final error of less than $10 \%$ was achieved.

To measure the water velocity at a distinct position in- or outside the fish's mouth as a function of the time, hot-film anemometry (TSI Inc., St. Paul, Minnesota) was applied.

A metal film resistor mounted on a probe (used type $1465 \mathrm{NaCl}$, tip diameter $1 \mathrm{~mm}$ ) was inserted in the flow. The resistor has a high temperature coefficient and was heated to a predefined constant temperature $\left(66.7^{\circ} \mathrm{C}\right)$. An electronic servo mechanism compensates the cooling of the probe by the streaming fluid and the eiectrical current needed for compensation was measured. In this way flow velocity measurements were made with an error of $1 \%$ and a bandwidth of $0-10 \mathrm{kHz}$.

Disadvantages of hot film anemometry are the unidirectional sensitivity of the probe and the time consuming calibration procedure.

The probe has a non-linear (4-th power) velocity-voltage characteristic i.e. the probe is very sensitive for velocities up to $1 \mathrm{~m} / \mathrm{sec}$. Above this value however the probe is less sensitive. The probe characteristic is rather independent of tank temperature and other factors and preserves a constant shape. Its initial value is very variable resulting in a possible voltage shift over the whole range of sensitivity. We therefore applied a calibration flow of $3 \mathrm{~m} / \mathrm{sec}$ before and after each experiment to define a reference voltage at the less sensitive part of the probe characteristic. When this voltage appeared to be constant during the experiment the velocity measurement was considered to be reliable.

Linearization of the electrical signals from the anemometer is usually carried out by a 4-th power polynomial regression of the probe characteristic. With the obtained coefficients an electronic polynomial linearizer (TSI type 1052) is preset.

However the 4-th power polynomial tended to oscillate at either the sensitive or the less sensitive part of the probe characteristic. Although this problem may be solved by applying weighting factors this procedure is rather inaccurate and time consuming. We have developed a linearization procedure by digitizing the measured signal with an $A D$-converter connected with a MINC-11 computer (Digital Inc.). The velocities were obtained by reading the calibration curves and linear interpolation. Spline functions can improve this interpolation-procedure (Koster, 1976).

\section{B4. Pressure measurements.}

As the recording and interpretation of pressures measured during prey suction in fish will be reported separately (Van Leeuwen and Muller, in prep.) here only some outlines of the measurement procedure are presented.

Pressures follow Newton's second law. The pressure measured in a stationary frame (i.e. the aqua- 
rium) has therefore another value than the pressure measured in an accelerating frame (the fish), (ref. Milne-Thomson, 1968: p. 89). Alexander $(1969,1970)$ measured pressures in a stationary frame. Because in his set up the transducer remains in the region of the mouth aperture no pressures due to acceleration of the fish were recorded.

Besides the influence of suction varied with the fish approaching the transducer. Furthermore an unnaturally low value of the pressure might be generated because the mouth aperture was sealed off by the transducer when the prey was snapped from the cannula.

Pressures measured with a fluid filled cannula, mounted inside the fish's mouth and connected to an external pressure transducer (Osse, 1976; Lauder, 1980b) are distorted due to acceleration of the fluid column inside the cannula. This results in pressure errors having the same order of magnitude as the actual value of the pressures ( $\mathrm{ca} .100 \mathrm{~cm} \mathrm{H}_{2} \mathrm{O}$ ). Other disadvantages are the low bandwidth $(<50 \mathrm{~Hz})$ of the transducers (Statham P23Db and P23Gb) and the phase shift occurring due to a damping coefficient of 0.65 .

The best way to measure the pressure is using a catheter-tip pressure transducer. Hereby it is essential that the sensitive area of the transducer is oriented parallel to the flow in order to avoid errors resulting from deformation of the flow by the transducer itself. Furthermore the transducer must have a high resonance frequency to provide a flat amplitude characteristic and no phase shift in the frequency range of the signals to be measured.

We tested several types of transducers (Entran, Gaeltec, Millar, self-made photo-electric) aided by reports from the Netherlands Institute of Ship Research (Wageningen) and the Delft Hydraulic Laboratory. The Millar PC 350 catheter tip pressure transducer appeared to be the most favourable type for our purpose. This transducer has a resonance frequency of about $30 \mathrm{kHz}$ thus providing a bandwidth of $10 \mathrm{kHz}$. Furthermore its temperature stability prevents signal distortion by cooling effects of the flow. This resulted in a maximal error of $5 \%$.

The dynamical calibration of pressure transducers was carried out applying a sudden pressure drop (positive or negative) to the transducer. This technique was described by Gabe (1972) and adopted by Lauder (1980b). In the latter paper the applied pressure drop generated by the ex- or implosion of a rubber membrane and with a relatively large volume of air and a small volume of water inside the calibration apparatus could be too slow to get a proper calibration and depends highly on the relative contents of water and air inside the apparatus.

Because the frequency response of the calibration apparatus was not given it is unclear whether the calibrations are distorted by resonance of this apparatus.

A reliable determination of the resonance frequency and damping coefficient of the transducer can be obtained by applying an impact to the transducer (submerged) as described in Van Leeuwen and Muller (in prep.).

The error most difficult to quantify is the effect of distortion of the flow in the direct neighbourhood of the pressure transducer. The influence of a boundary layer formed at the wall of the transducer (and so at its sensitive area) appears to us to be small. The effect of velocity and acceleration distortions near the transducer may be considerable.

The velocity distribution about a stationary transducer in a varying flow varies from a value of zero at the stagnation point to $10-20 \mathrm{~m} / \mathrm{sec}$ at the transducer's sidewalls. This great difference gives rise to pressure distortions of the same order of magnitude as the pressures to be measured.

An analogue consideration holds for the acceleration-pressures and for a moving pressure transducer.

Despite the critical remarks above the measured pressures appeared to agree well with pressures obtained from model calculations (cf. D4 and E). 


\section{Construction of the model.}

\section{C1. Limitations OF MODEL STUDIES.}

In fish an overwhelming variety of prey suction mechanisms exists. In order to obtain a deductive model (Dullemeyer, 1974) in which different suction processes can be simulated, including those not existing in nature, we tried to derive the essentials of form and motion of the suction feeding mechanism by comparing high-speed films of fishes feeding in different ways and by dissecting a variety of fish species. We focussed thereby our attention to elements common for most of the fishes and not to different anatomical details.

Such characters are: a streamlined body form, levation of the neurocranium, depression of hyoid and lower jaws, abduction of the suspensoria and operculars, protrusion of the jaws, retraction of the pectoral girdle and opening of the initially closed opercular slits.

Swimming and biting movements are also taken into account.

Through reduction and abstraction all these characters are compiled in a set of form and motion parameters.

Model construction in functional morphology consists of the creation of the quantitative relation between the characters of the fish's suction system as mentioned above and quantities representing the function as e.g. water velocity, -acceleration, -impulse and the pressure during suction, the energy expenditure, the shape of the flow, the sucked volume of water, the motion of the prey, the moment of prey capture and the velocity of the predator.

As the physics and the morphology of the sucking system are extremely complex the quantitative results of the model can only be used for qualitative predictions in actual fish. If certain demands of function (e.g. flow velocity, prey size) are given, calculations from there result in series of morphological possibilities. Each possibility in itself is a tight network of constraints originating from the whole set of coupled parameters.

The hazards of the model approach, not only by omitting important parameters or changes of the system of coordinates used (see C4, D3.3), but also through manipulations with a high number of parameters are well known. We tried to avoid this by inserting a long list of simplifying approximations and their consequences.

The choice of only one actual fish species as a starting point for model construction implies a great risk to explain only that particular type of suction feeding and to overlook the essentials of suction feeding in general.

Lauder $(1980 \mathrm{a}, \mathrm{b})$ presents a model-like explanation of the relation between movements and pressures actually measured during feeding in Lepomis.

This approach i.e. taking the measured data as a base for the construction of a model which has to generate these phenomena again has the disadvantage that only an explanation is given for the particular results obtained. As these results (i.e. pressures) depend on many variables, as explained below, the conclusions drawn do not explain general aspects of prey suction. 


\section{C2. UNSTEADY FLOW.}

(Milne-Thomson 1968; for formulas: see Appendix I).

The suction process generally has a duration less than $110 \mathrm{msec}$ (Plate 1, Fig. 10). This means that at zero time the velocity of the water inside the mouth is close to zero and that e.g. $50 \mathrm{msec}$ later the prey is engulfed with a velocity up to $10 \mathrm{~m} / \mathrm{sec}$. Besides, the velocity of the predator may change rapidly due to suction and swimming. The acceleration reached in this example is about 40 times the acceleration of gravity and more extreme values are quite possible. Due to these enormous accelerations the flow is highly unsteady.

In unsteady processes both velocity and acceleration must be taken into account. When a ball rolling up a hill is observed it is immediately clear that at an earlier instant the ball has been pushed upwards and the observation is not explained by assuming that the direction of the gravitational force has been changed.

A hydrodynamical analogue of this example is a mass of water moving against a pressure gradient i.e. although the pressure inside the fish's mouth may possess during a certain time a positive value with respect to the environmental pressure it is possible that a flow enters the mouth.

A flow is completely characterized when velocity and pressure as a function of the time and position are known.

The velocities in a closed system of moving fluid are obtained by solving the equation of continuity. This equation is the mathematical formulation in terms of velocity that a certain mass of fluid is conserved in the system. The direction of the velocity at different positions in space is represented by a streamline pattern. In steady flow the streamline pattern has a constant shape implying that the path of a particle coincides with a certain streamline. When the flow is unsteady the shape of the streamline pattern varies as a function of the time and so a particle path generally does not represent a streamline. This fact has evidently considerable consequences for visualization of the flow (Van Leeuwen, in prep.).

So e.g. Schlieren's method, injecting ink and related techniques (Merzkirch, 1974; Thompson, 1972) cannot be used for the visualization of unsteady flow because the line-patterns obtained represent a highly complex combination of path lines and do not at all represent the actual flow. Using polystyrene spheres this problem is at least reduced because the flow is shown at successive places.

The pressures in the system are calculated by substitution of the velocity as a function of position and time in the equation of motion. This Navier-Stokes equation (essentially Newton's second law formulated for a fluid) describes the relation between pressure and motion thereby including frictional forces.

When friction does not play an important role the N-S equation is reduced to the frictionless, unsteady equation of motion. Here the pressure is determined by two components: a pressure due to the velocity and a pressure due to the acceleration of the water. This implies that it is impossible to deduce the magni- 
tude and direction of the water velocity from the pressure as erroneously has been done by Lauder (1980 a, b), because the contributions of the velocity- and acceleration pressures are unknown (Muller et al., 1982).

This equation can be further reduced to Bernoulli's equation in the case of steady motion, providing a direct relation between water velocity and pressure. Osse (1969) first considered water motion in sucking fish by using this equation and calculated a peak pressure of roughly $-20 \mathrm{~cm} . \mathrm{H}_{2} \mathrm{O}$ for the perch. However this approach is unsatisfactory because peak pressures actually measured during suction reach values up to $-650 \mathrm{~cm}$. $\mathrm{H}_{2} \mathrm{O}$ (Alexander, 1969, 1970; Casinos, 1973, 1974; Lauder 1980a, b; Osse, 1976; Osse and Muller, 1980; Van Leeuwen and Muller, in prep.).

During prey suction a fish usually moves in a forward direction. This motion is partly a result of the reaction forces generated by the suction and partly caused by movements of fins, body and tail. So the streamline pattern near the fish's mouth varies as a function of time and it is also generated at a changing site.

The analysis of the flow velocities is therefore considerably simplified when the flow is described with respect to the moving frame of the fish e.g. with respect to the (protruding) mouth aperture or with respect to the opercular slits. Besides, this flow is the biologically significant phenomenon for it determines the fish's success in prey capture. The flow in the earth-bound system of coordinates allows the determination of the forces exerted by the fish and so helps to derive conditions for the opening of the opercular valves (Van Leeuwen, in prep.) and to couple suction and swimming.

The occurrence of e.g. a positive pressure peak in the opercular cavities when the fish starts sucking is a direct consequence of the acceleration of the fish along its axis and follows directly from the unsteady flow. For details see D4.1.

\section{C3. SIMPLIFYING APPROXIMATIONS FOR THE SUCTION PROCESS}

Prey suction is the ingestion of water and prey by expansion and compression of the mouth eventually coupled with opening of the opercular valves.

As a result of suction the fish moves forward in an earth-bound frame. This forward motion is supported by swimming movements by fins, body and tail. The total process will be referred to as: "the suction process". Plate 1 and Table I give a survey of suction movements for eight fish species together with an accurate specification of the events occurring.

The construction of a model of prey suction is a process of simplification of the actual situation allowing the application of physical laws. This section deals with the justification of the involved simplifying steps (C3.1-C3.6).

\section{C3.1. Friction can be neglected}

Neglection of the friction is allowed because the suction process is very fast (Muller et al., 1982).

The thickness of the boundary layer (i.e. the region where the friction plays an important role) is restricted to $1 \mathrm{~mm}$ for a suction process with a duration 

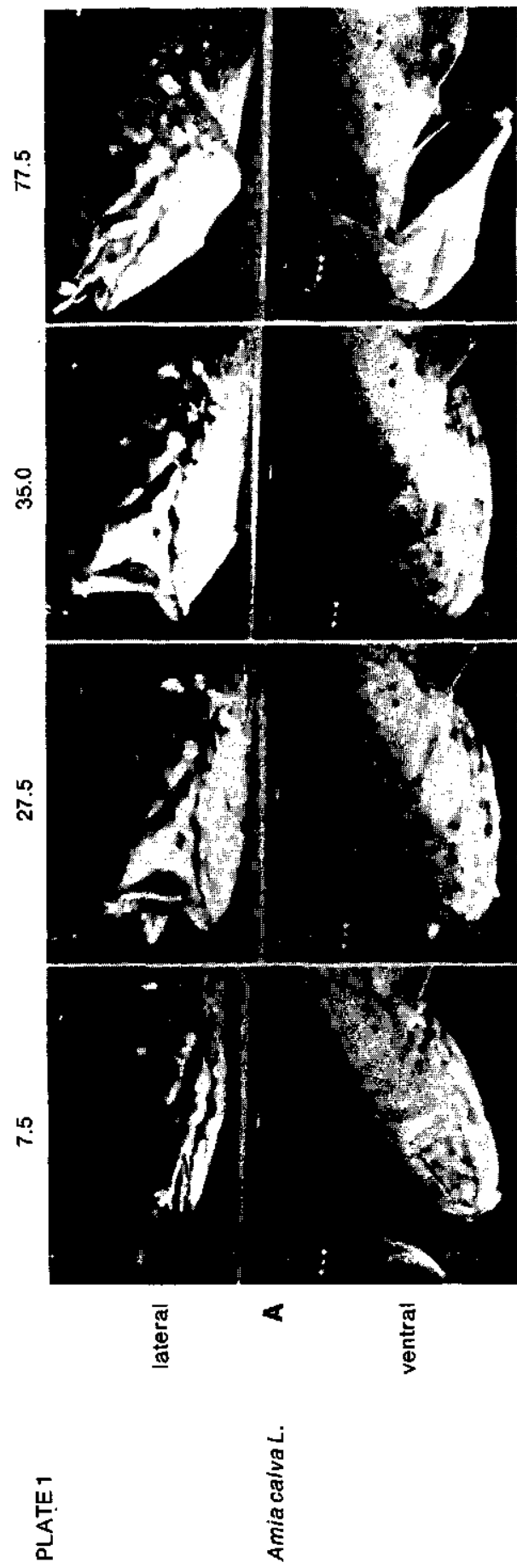
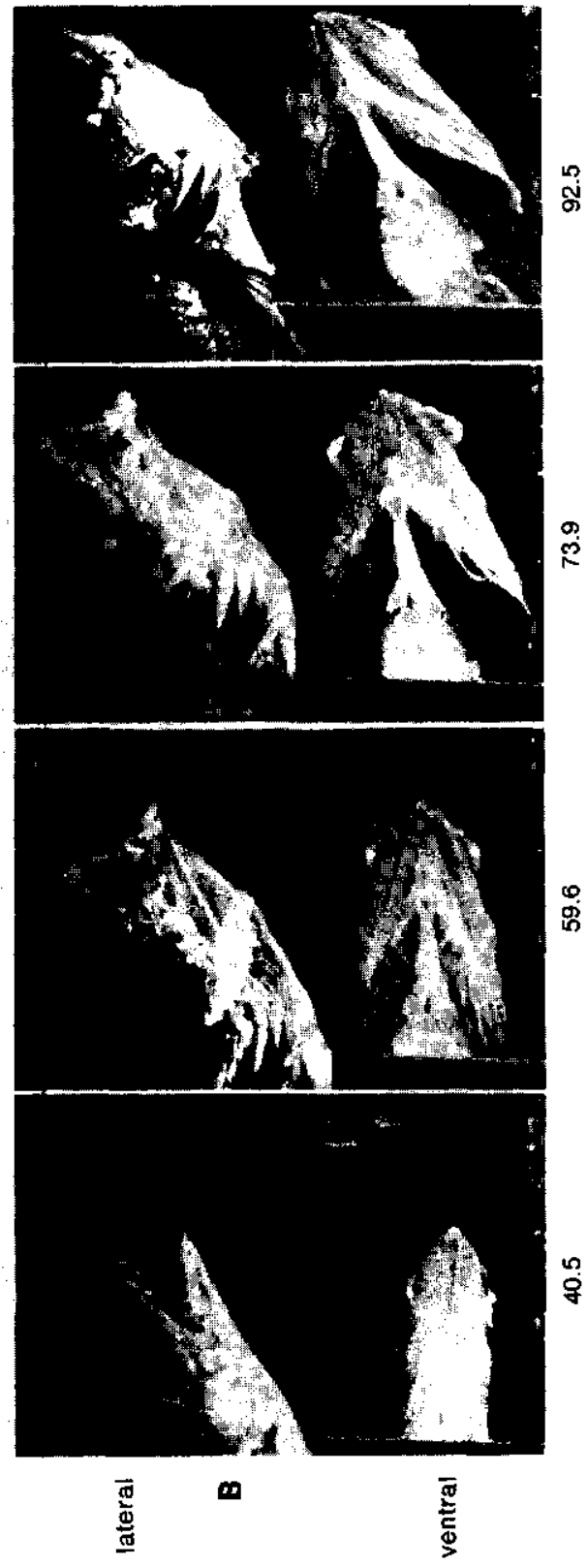

亳 


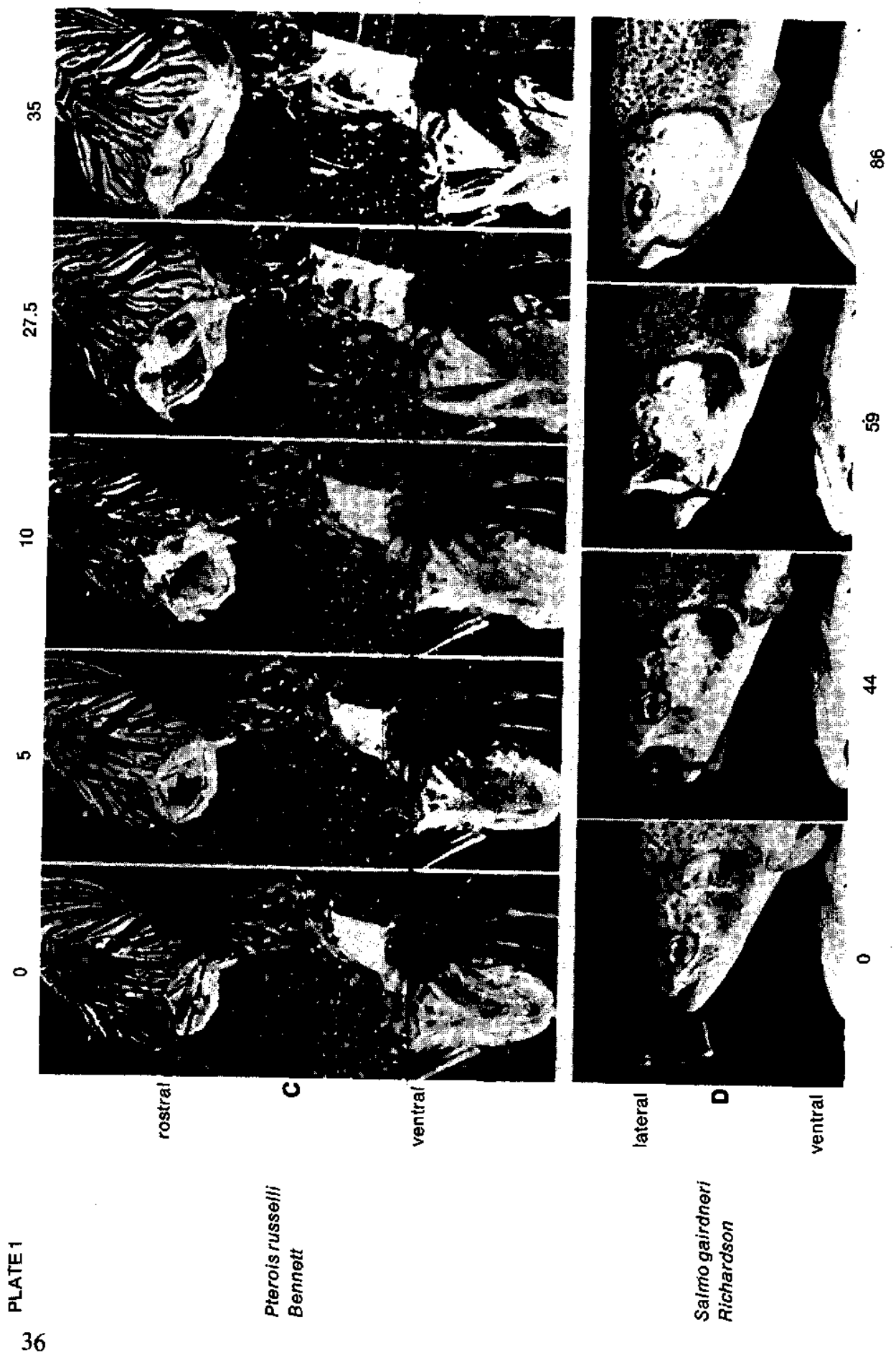




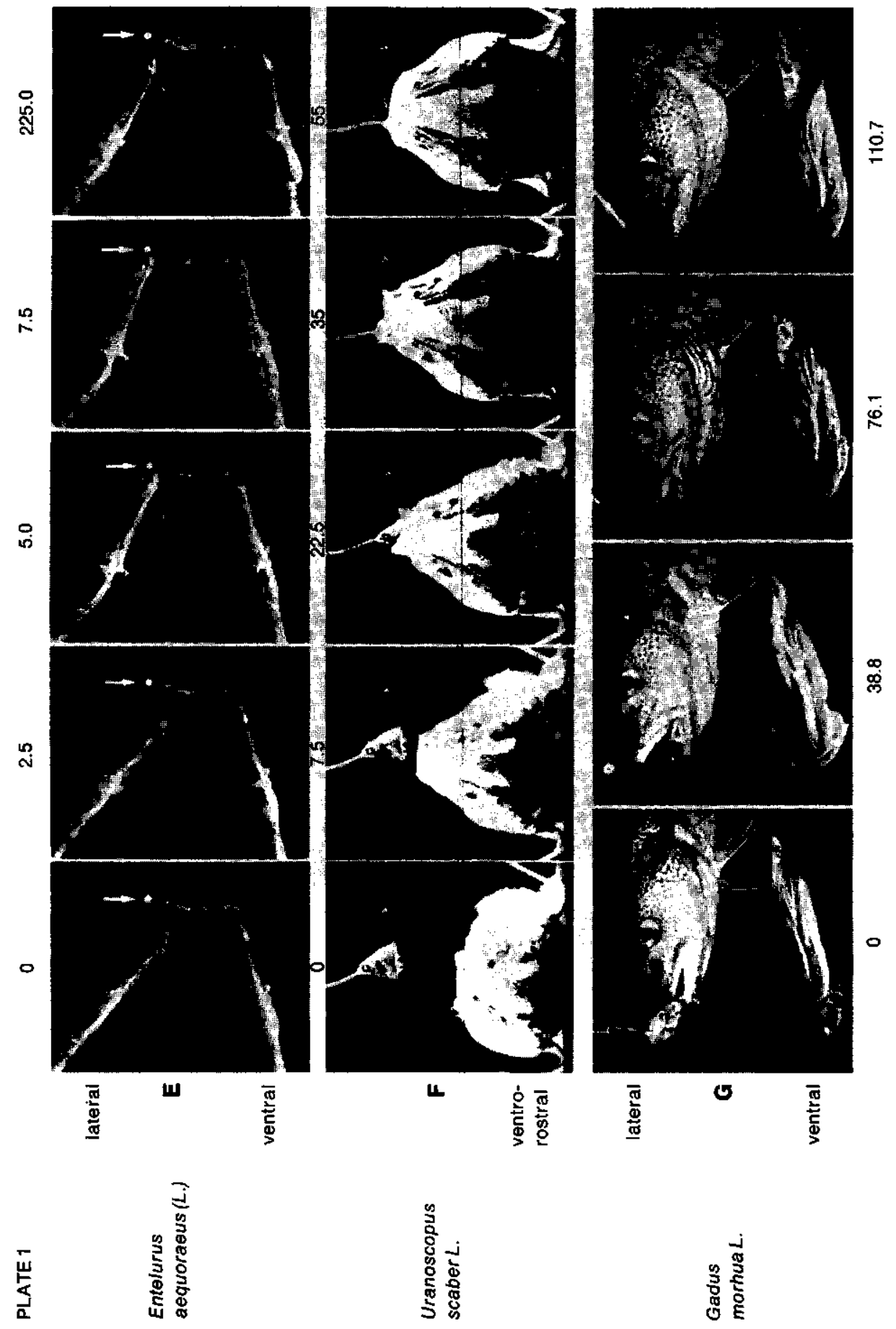




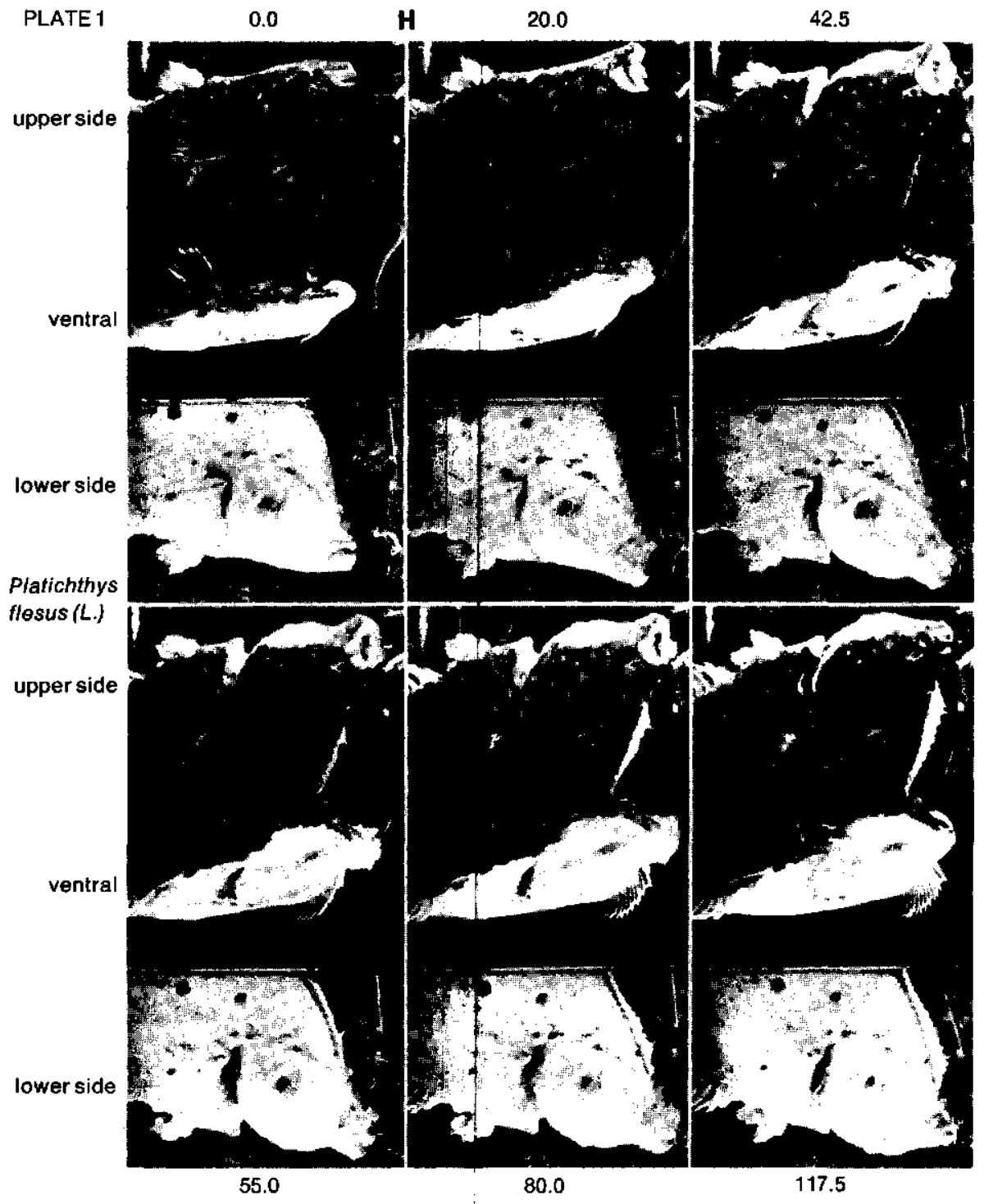

Plate 1. Examples of the suction act by eight fish species feeding in a highly different way. The numbers indicate the time in msec. Motion curves of Amia, Stizostedion, Pterois and Gadus are given in Fig. 5, 9,11 and 12 (not necessarily the same act).

Generalized elements of the suction process are:

1) approach of the prey, 2) aiming at the prey by protrusion, 3) rapid expansion of the head by suspensorium- and operculum abduction and hyoid depression, 4) a dart to the prey by a strike of the tail and/or propelling movements with the fins.

In the following descriptions subsequent pictures are denoted by the numbers $1,2,3$, etc. 
A: Amia calva $L .:$ headlength $92 \mathrm{~mm}$.

1) Initial position. The time $t=7.5 \mathrm{msec}$ is chosen instead of $t=0$ because in that period hardly an expansion occurs and the animal only slowly approaches the prey. 2) By expansion of the buccal cavity the prey is sucked. In this case the animal does not much translate and the flow towards the mouth aperture is undirected. Note the closure of the mouth angles by the maxillaries. 3) Further suction and transport of the prey inside the mouth by a strong hyoid depression and by expansion of the opercular cavities. The opercular valves are still closed. 4) Closure of the mouth and further expansion of the opercular region with open valves. Note the streamlined shape of the gills and the pectoral girdle (section D3.2). Although buccal and opercular expansion are very separate in this case, this is an example of "low- $\tau$-suction" (section D1.3.2). However also elements of the "volume-suction"-type (D1.3.2) are present due to the hyoid depression and the small translation (lack of swimming). This movement is for Amia a fairly strong and fast one $\left(u_{m}\right.$ is ca. $\left.1.5 \mathrm{~m} / \mathrm{s}\right)$.

Suction movements of this animal were very variable (see Fig. 11, 13, 22).

B: Stizostedion lucioperca L.: headlength $90 \mathrm{~mm}$.

1) Initial position. Between $t=0$ and $t=40.5 \mathrm{msec}$ the fish fastly swims towards the prey ( $\mathrm{l} \mathrm{m} / \mathrm{s}$ ) and opens its mouth. 2) Suction by further mouth opening, hyoid depression and abduction of suspensoria and opercula. The angles of the mouth aperture are closed off by the maxillaries. A slight protrusion is present. The valves are still closed. Considerable swimming is employed to capture the prey which is moved away by the experimenter. 3) Rapidly (ca. $13 \mathrm{msec}$ ) after the beginning of opercular abduction the valves are opened. Note the streamlined gills and pectoral girdle (section D3.2). When the valves open, the mouth aperture starts to close. The prey is missed. 4) Mouth aperture fully closed. Operculars again adducting but opercular slits still very wide. This is an example of a violent and strong suction act showing "low- $\tau$-suction with swimming" (section D1.3.2).

\section{C: Pterois russelli Bennett: headlength $40 \mathrm{~mm}$.}

Repeated snap after the real suction movement to transport the prey inside the mouth. Although this is in fact a handling movement it resembles very closely a real prey-suction movement.

A snap from lateral has been published elsewhere (Muller et al., 1982). The rotational symmetry of the buccal cavity during suction is evident from these pictures. At the end of the suction act the mouth aperture has been closed with still protruding jaws. Note the enormous difference in suspensorium- and operculum abduction between pictures (1) and (5) and the short duration of the suction act. Although the valve in this example opens relatively late (for Pterois), i.e. ca. $19 \mathrm{msec}$ after the start of opercular abduction, this suction movement can be characterized by "low- $\tau$-suction with protrusion" (section D1.3.2).

D: Salmo gairdneri Richardson: headlength $51 \mathrm{~mm}$.

1) Initial position: mouth aperture just formed. Opercular expansion still zero. The fish approximates the prey by rapid swimming movements. 2) During continuous swimming the mouth is opened and opercular expansion occurs. So, a cylinder-like profile form is achieved in this phase. The water in front of the mouth aperture containing the prey remains stationary because swimming is compensated by suction (section D3.3.4). 3) The valves open. This event, together with a continuous opercular abduction accomplishes the avoidance of stagnation (see also Van Leeuwen, in prep.). The prey is however not fully engulfed due to its elongate shape. 4) Mouth closure going together with still an abduction of the operculars. This is a typical example of "low- $\tau$-suction with swimming" (see D1.3.2).

E: Entelurus aequoreus (L.): headlength $25 \mathrm{~mm}$.

1) Start position. The fish has approximated the prey (indicated by the arrow) very closely 
and has carefully positioned its snout relative to the prey. Both predator and prey are stationary. The fish does not aim to the small crustacean but to the lowest lead-sphere. Note the posture of the eyes. 2) The snout starts to rotate towards the prey. Note that both hyoid and prey remain at the same position. Abduction of opercula and suspensoria hardly occurs. 3) The "prey" is captured in 5 msec. Opercula and suspensoria slightly abducted. The hyoid is fully released but moves, relative to the head of the fish, still caudally. 4) Attempt to transport of the prey by further expansion of the mouth showing the stereotypy of the motion, even when no real prey has been captured. 5) Reverse rotation of the snout. The hyoid is brought again to its rest position. Transporting movements for the prey are pursued as is apparent from the huge opercular abduction a long time after the actual feeding movements.

Refer for this type of suction to D3.3.4.

F: Uranoscopus scaber $L .:$ headlength $62 \mathrm{~mm}$.

View from rostral. 1) Rest position. 2) A dart to the prey by pushing off the body to dorso-frontal with the pectoral and pelvic fins. The mouth opens and protrusion of the premaxillae occurs. 3) Prey captured. Note that suction dominates over "forward"-translation because the prey has been actively sucked by hyoid depression. The opercula and suspensoria are only slightly abducted. 4) Transport of the prey inside the mouth by a further expansion of the opercular cavities. 5) Mouth closed again, jaws still protruded. A considerable opercular abduction is still present. The moment $t=\tau$ could not be determined because the valves are covered by a flap formed by the operculars. This suction movement is characterized as "suction with protrusion and translation of the body". The flow relative to the mouth aperture is therefore highly directed (see D3.3.4).

G: Gadus morhua L.: headlength $100 \mathrm{~mm}$.

1) Start position. The fish has approximated the prey by slight swimming movements $(0.2 \mathrm{~m} / \mathrm{s})$. The prey is touched by the snout tip. 2) Suction of the prey by mouth opening and a strong hyoid depression. The prey is actively moved into the mouth by the flow. Note the lack of protrusion and the small expansion of the opercular cavities at this moment. 3) Transport of the prey inside the mouth by a huge opercular expansion and further hyoid depression. The mouth aperture is being closed. The opercular valves are, even at this delayed moment, still closed. So, suction takes in fact place with closed valves. 4) Mouth aperture fully closed, opercular valves open. By adduction of the opercula the water enclosed inside the mouth is forced to caudal. This rather slow and weak suction act is carried out by a large cod in a small aquarium and so it is an example of "high- $\tau$ suction" ("volume-suction", section D1.3.2). It is accompanied with small swimming movements.

H: Platichthys flesus (L.): headlength $71 \mathrm{~mm}$.

1) Start position. The picture is divided in an upper side, ventral view and lower side. The animal lies on a glass plate, upper and lower sides are projected to the camera by means of mirrors. The animal levates its head from the glass plate by contraction of the body muscles of the upper side. In the natural habitat this means that the head is raised out of the sand to a definite distance above the bottom. So the animal will suck its prey in the free water. 2) Further levation of the head and aiming at the prey by protrusion. The neurocranium is also levated (in the plane of the flattened body). The animal moves slightly forward. No considerable expansion of the head does occur. 3) Suction of the prey by expansion of the opercular region, by further levation of the neurocranium and depression of the hyoid. The opercular valves are closed (only to judge from movie studies). The fish translates slightly. Protrusion still contributes to the forward motion of the mouth aperture. This aperture is rotational symmetric (ref. Plate $2 F$ ). The prey is actively sucked (note the local deformations of the worm). The flow toward the mouth aperture is rather directed (vortex + parallel stream). 4) Further suction but no translation anymore. So an undirected flow toward the mouth aperture oc- 
curs. The prey is still visible. In another snap a prey was sucked from a position below and halfway the head. The valves are still closed. Note the gliding off of the membranous branchiostegal flaps along the pectoral girdle. 5) The valves are opened (ca. $65 \mathrm{msec}$ after the start of opercular abduction), first the upper valve, $5 \mathrm{msec}$ later the lower valve. Water flows to caudal (observed from spheres in other acts). No considerable translation of the mouth aperture has occurred. This aperture is still fully opened. 6) Mouth aperture closed. Note its retracted position. The water inside the mouth is forced to caudal by compression. The lower valve has been closed again and water flows through the upper opercular slit. This suction movement can be characterized by "high- $t$-suction". However in the beginning of the act the flow to the mouth aperture is rather directed due to protrusion and translation of the body.

of about $100 \mathrm{msec}$. Such relatively slow suction movements are generally carried out by the larger predators like adult cod, bowfin and trout (Plate $1 \mathrm{G}, \mathrm{A}, \mathrm{D}$ ). Smaller fish suck their prey in a much shorter time (e.g. Plate 1E) which corresponds with a thinner boundary layer (Fig. 1).

Some fishes (e.g. Salmo, Esox, Serranus) capture their prey sometimes after a chase. The prey may generate vortices in order to escape. In fast flowing water (as e.g. occurring in brooks) considerable turbulence exists. To apply the model it must be checked in these cases if the flow is frictionless. This is done by comparison of the boundary layer thickness with the dimensions of the animal's head. The negligibility of the friction is in itself a fact which implies a hydrodynamical advantage for the predator because the occurrence of friction drag is avoided.

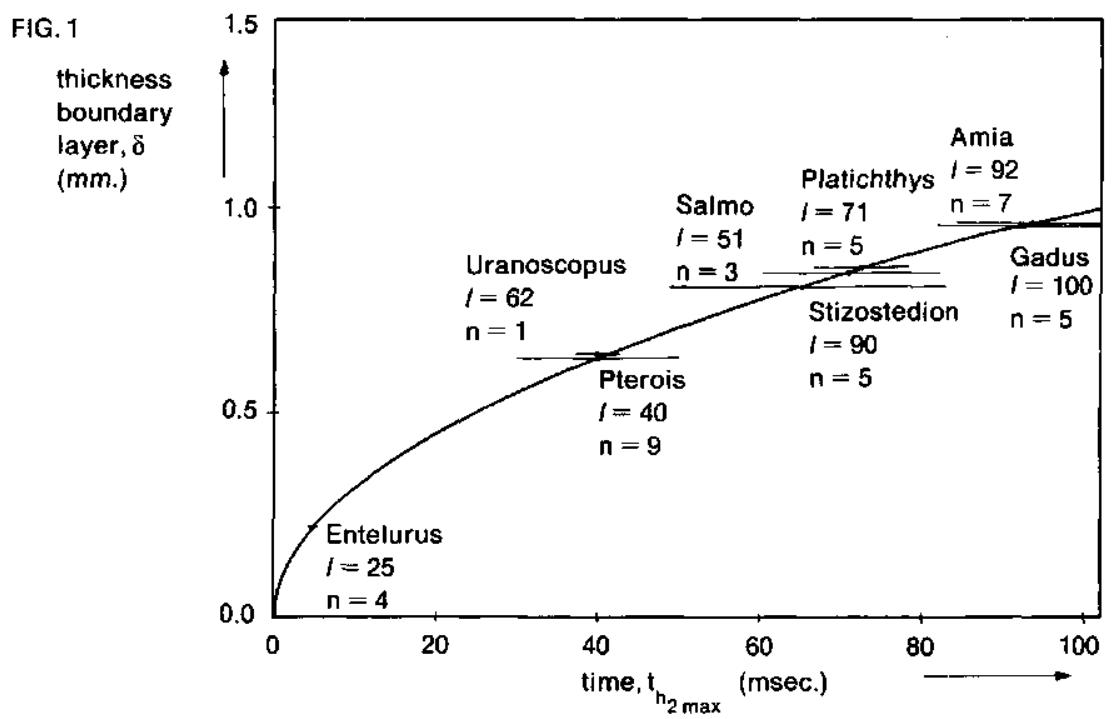

FIG. 1. Thickness of the boundary layer $(\delta=\sqrt{v t})$ as a function of the duration of the suction process. Examples for some fish species are given.

The horizontal lines denote the variation of $t_{h_{2 \max }}$ measured, the dots the average values. Note that even in large, relative slow sucking fishes the boundary layer is very small compared to mouth dimensions.

$n=$ number of feeding movements, $l=$ length of mouth $(\mathrm{mm}), t_{h_{2 m a x}}=$ time of maximum opercular abduction, $\delta=$ thickness of boundary layer, $v=$ kinematic viscosity, $t=$ time. 
FIG. 2
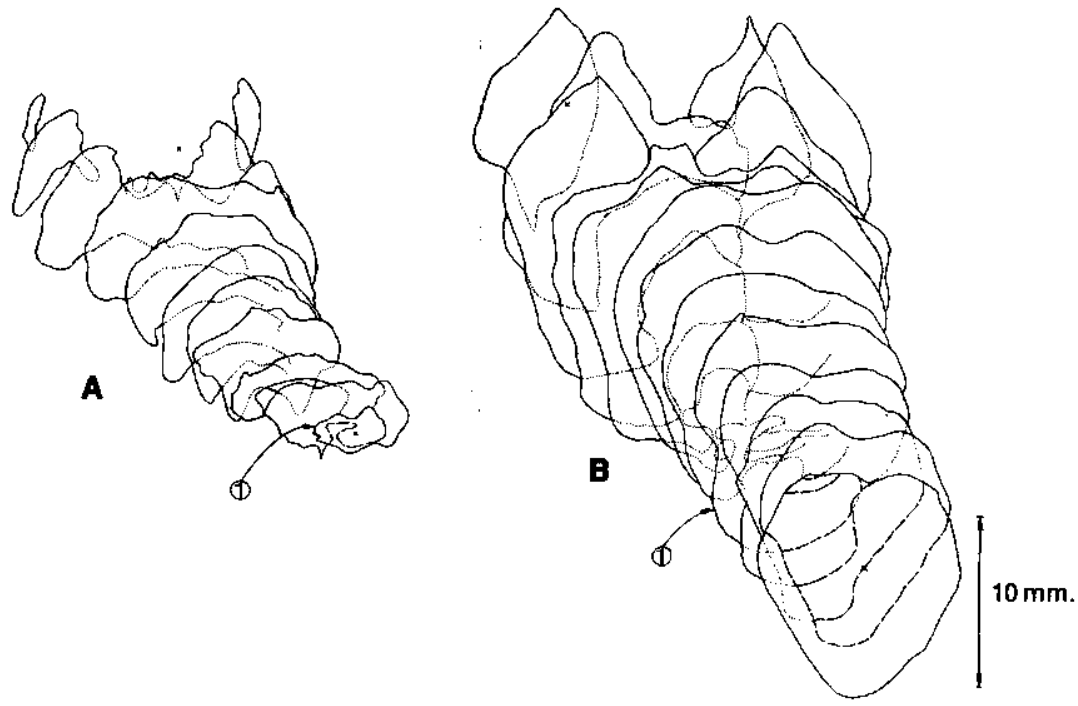

Fig. 2. Shape of the mouth cavity of Pterois russelli $(\mathrm{SL}=10 \mathrm{~cm})$.

A: compressed start situation $(t=0$, mouth length $=23.5 \mathrm{~mm})$, B: expanded situation $(t=37.5 \mathrm{msec}$, mouth length $=28.2 \mathrm{~mm})$. The $\mathrm{X}-\mathrm{X}$ designate the long axis. These reconstructions are obtained from serial sections of casts of compressed and expanded positions taken from the movie frames. The gills were removed. The expanded situation clearly shows the strong tendency towards rotational symmetry. The importance of protrusion can be judged by comparing the positions marked 1 in $A$ and $B$. The dotted lines indicate the hyoid (A) and the isthmus of the pectoral girdle (B) in the floor of the mouth.

\section{C3.2. Rotational symmetry; profile form chosen.}

This condition provides a two-dimensional approach of the problem (in cylinder coordinates) instead of an almost unsolvable three-dimensional one.

At first glance fish do not possess a rotationally symmetric mouth (buccal and opercular) cavity. When the fish's mouth is in the rest position, the buccal cavity is elongated and dorsoventrally flattened and more or less divided in lateral compartiments by the hyoid. The opercular cavities are occupied by the gills (Fig. 2A, see also Plate 2G). In the expanded situation however the buccal cavity has an almost perfect cylindrical or weak conical shape. The opercular cavities together form a conical tube (Fig. 2B, Plate 2G). In the latter region the symmetry is considerable disturbed by the gills, the pectoral girdle and the skull.

The sketched picture holds for many fish species and is even true for flatfishes (Plate 1H, Plate 2F). Motion analysis of filmed suction movements proves that the buccal cavity becomes rotational symmetric early in the suction act (Fig. 3,12 ).

A model approach based on rotational symmetry appears to be accurate for the flow in the buccal cavity. The error in the velocity is estimated to have the 
PLATE2
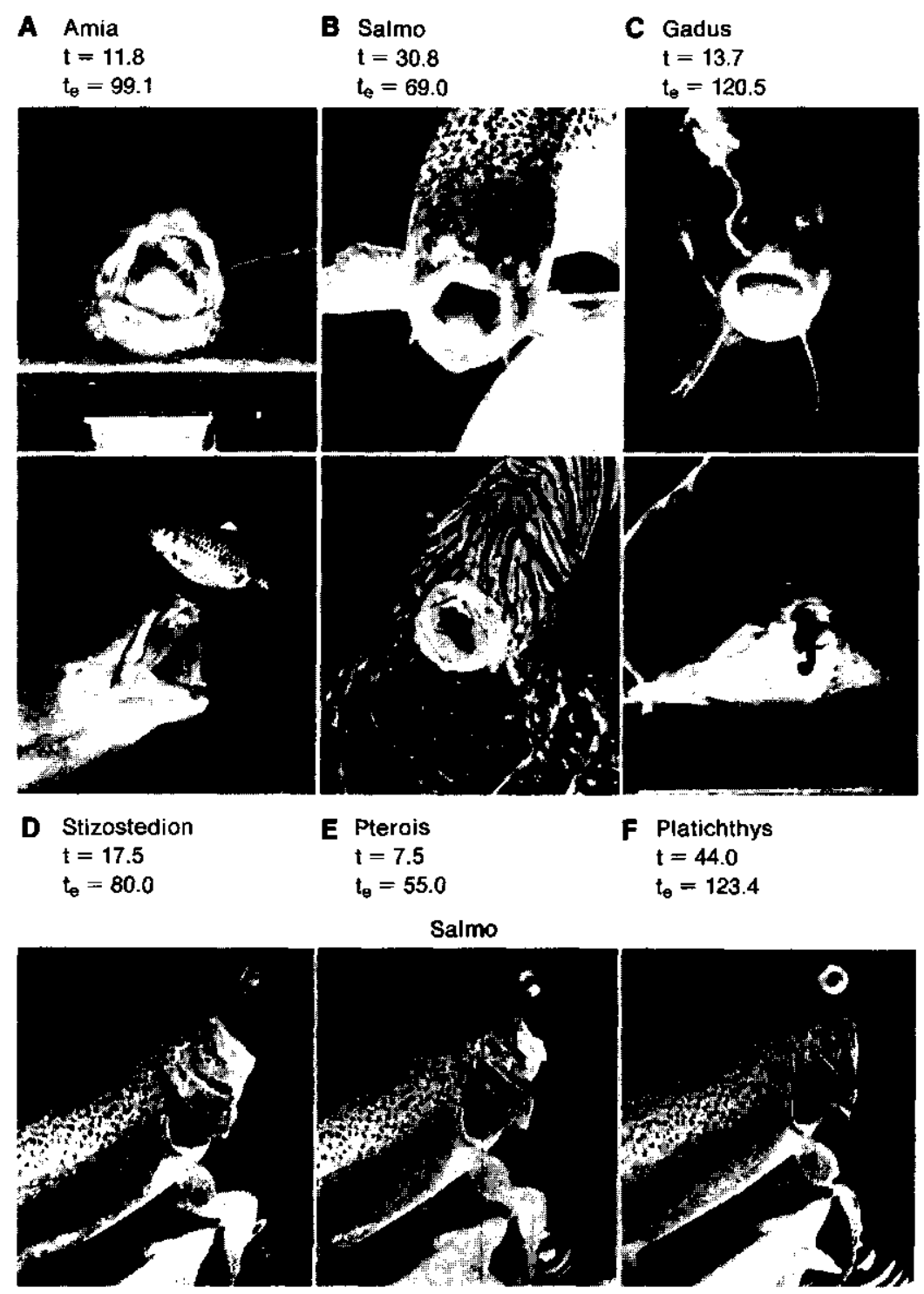

G1

82.0

G2

93.0

G3

109.0

Plate 2. Shape of mouth aperture and opercular slits at some instants of the suction act. The animals are the same as in Plate 1 .

The pictures A--F show the rotational symmetry of the buccal cavity at time $t$. The time $t_{e}$ indicates the end of the suction act.

The pictures G1--3 show the rotational symmetry of the opercular cavities (ventral images) and the streamlined shape of gills and pectoral girdle during a suction act of a rainbow trout. Note the motion of the gills caused by the flow in $\mathrm{Gl}$ when the abduction of the operculars is very fast. Time indicated in msec. 

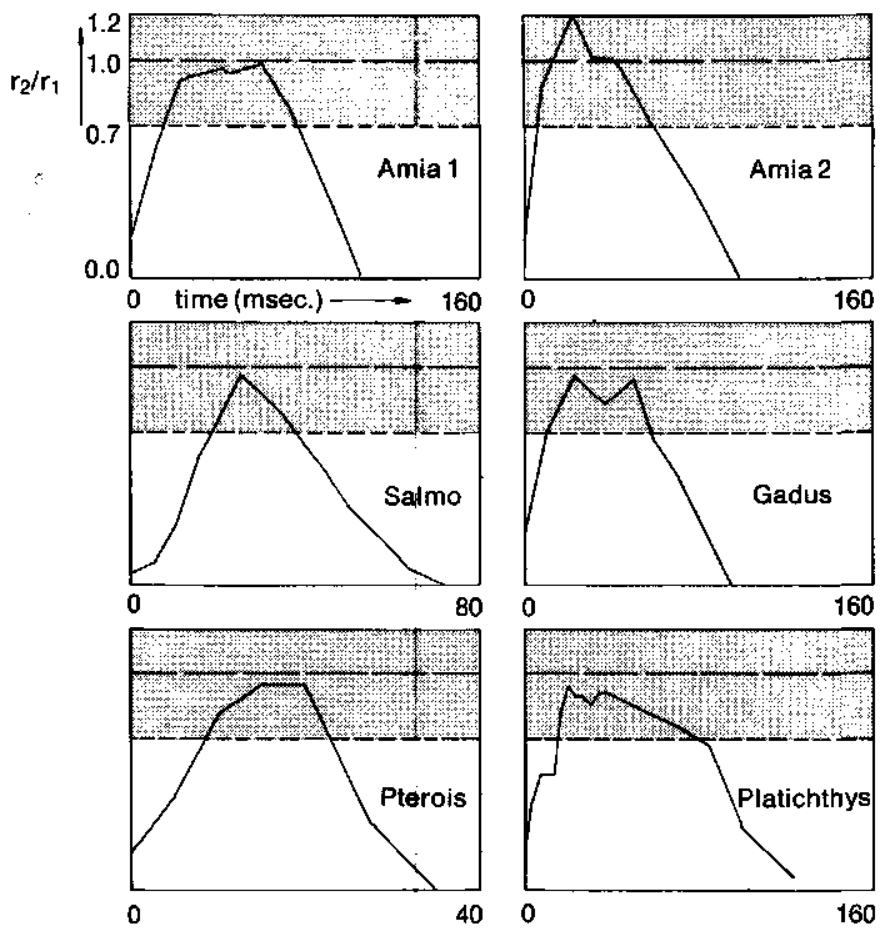

F1G. 3. Graphs showing the rotational symmetry of the mouth aperture actually achieved during the suction process. Time (abscissa) is in msec, rotational symmetry is expressed in the ratio of the magnitudes of the height $\left(r_{2}\right)$ and the width $\left(r_{1}\right)$ of the mouth aperture. The shaded area denotes the rotational symmetric region. The measurements were taken from movie pictures from rostral. The prey is always captured when the mouth aperture approaches rotational symmetry (cf. Fig. 17). Note that even the flatfish Platichthys becomes rotational symmetric early in the suction act. The animals are the same as in Plate 1.

same order of magnitude as the error in the symmetry (i.e. less than $10 \%$ ) when the fish's mouth is expanded. Applying a similar criterion for the opercular region one gets an error of about $60 \%$ in the expanded situation.

Obviously a much greater error is made when the opercular region is folded together. However in that case the branchiostegal valves are closed and the velocities occurring are low. Thus the errors due to asymmetry occurring in the opercular region do not seriously affect the values of the velocities in the buccal region. The errors in the buccal water velocities, introduced by a wrong estimation of the opercular volume, can be serious and are treated in D1.2.

Important errors in the pressure originate from differentiation of velocities with respect to time. These accelerations must be integrated over all the positions in the mouth cavity. In doing this the relative errors remain at least constant implying that errors in the rotational symmetry are of minor influence on the pressure. 
According to the principle that a circle has a maximal area-circumference ratio a rotationally symmetrical mouth allows for maximal flux and undisturbed flow (Osse, 1969 p. 377). Lauder (1979) carried out some simple experiments in order to demonstrate the hyddrodynamical advantage of a rotationally symmetrical mouth aperture.

The condition of rotational symmetry of the sucking structures is thus in accordance with a hydrodynamic optimization principle with respect to these structures viz. that given a certain mouth size a maximal volume flow occurs.

Obviously the simplest rotationally symmetrical profile is a cylinder. This profile provides a surveyable and satisfactory analytical solution for the water velocity and the pressure but a rather rough description of head form and movements (see D1.1, D1.2).

A conical profile (Fig. 4) representing a fish head whereby the movements of buccal and opercular region can be chosen independently (resulting in different combinations of the movements with respect to duration, amplitude and phase) provides greater flexibility for simulation.

It also forms a more realistic picture of the suction process with still a minimum of model parameters (see $\mathrm{C} 4$ ). As an analytical expression for the calculation of the velocities and pressures becomes too complex computer simulations were a necessity (Muller et al., 1982).

FIG. 4

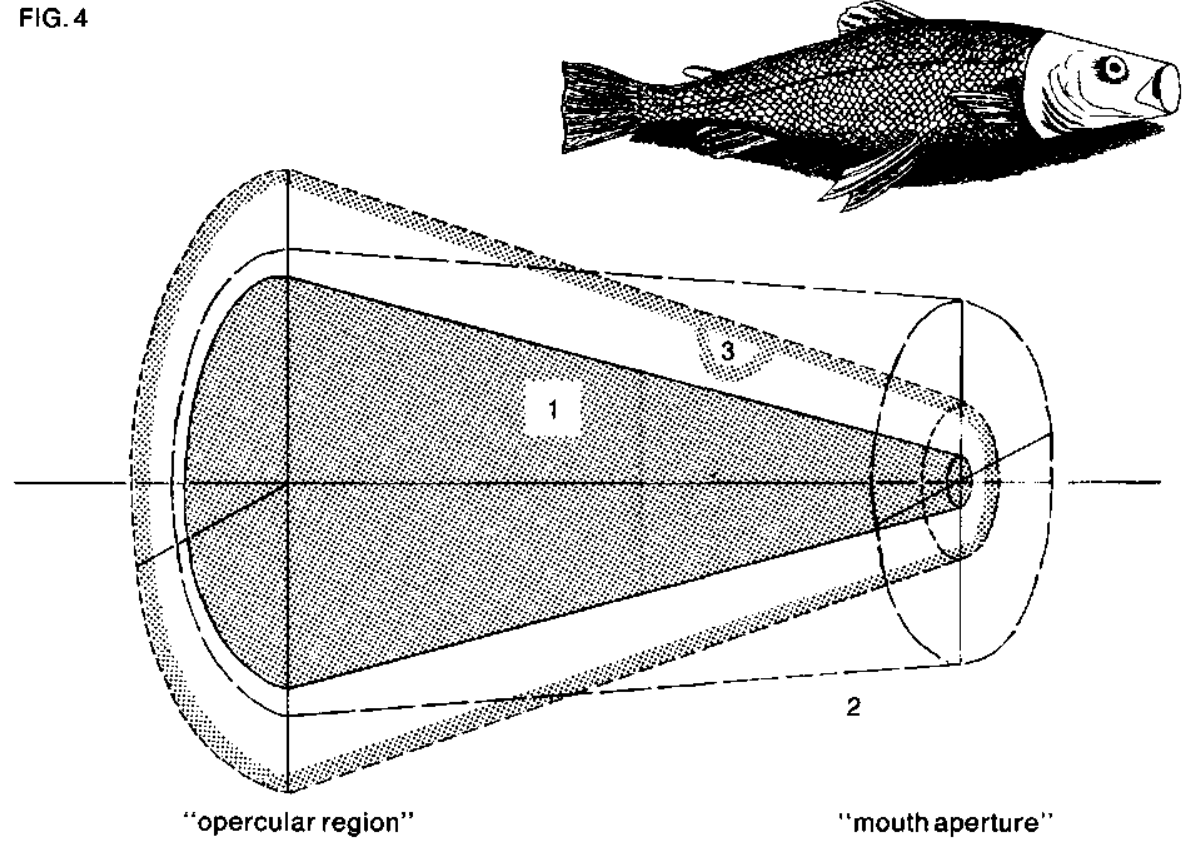

FIG. 4. Diagram of an expanding and compressing conical profile. 1) Initial, and also final, stage. 2) The buccal region has been expanded widely; the opercular region starts to expand. 3) The buccal region is compressed whereas the opercular region is still expanding. 
The movements of the profile are defined with a relatively simple function giving profile amplitudes in accordance with excursions of the fish's head measured from the movie frames (D1.1, Fig. 11).

\section{C3.3. The prey is an element of the sucked water}

When in a parallel stream a surface is postulated enclosing a certain volume of fluid the shape of the fluid body remains constant. Therefore in such a flow a body of the same density as the fluid does not disturb the motion of the water. Most aquatic animals and thus fish preys possess a density approximately equal to the surrounding water. In a parallel stream the dimensions of the prey may therefore have any value.

During prey suction the streamlines may converge. This is called a contracting flow. In such a contracting flow the dimensions of the prey are important and only when the deviation of a uniform flow is small with respect to the size of the prey the influence of the prey in a contracting flow can be neglected. For example: if streamlines in the neighbourhood of the prey deviate less than $5 \%$

FIG. 5
A Without prey
B With prey
capture

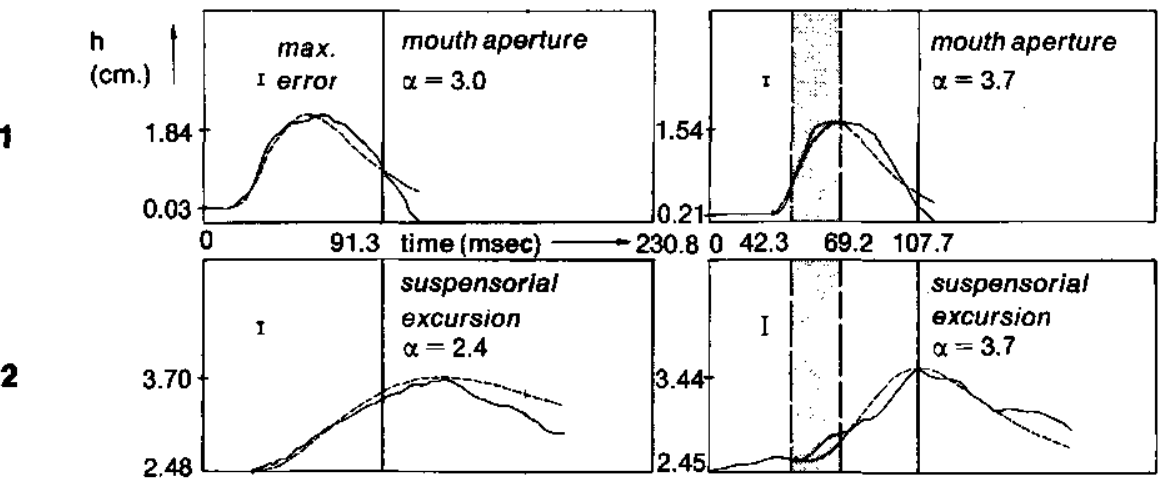

3
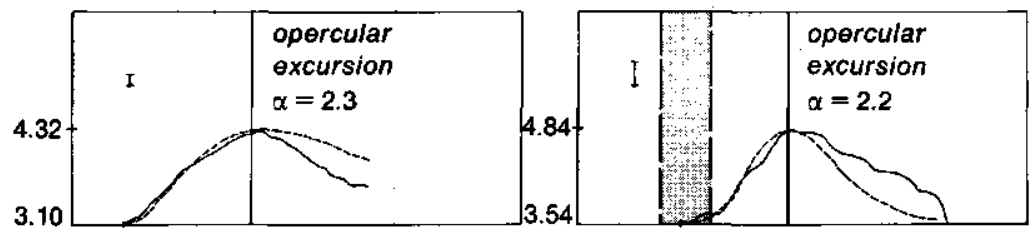

FIG. 5. Movement graphs (-) and fitted movement curves (- - ) of snaps of Gadus showing the similarity between a fruitless (A) and a successful movement (B). It is clear that the suction movement is not affected by prey capture. Mouth length $10 \mathrm{~cm}$, dimensions of profile radius and excursions of head parts (ordinate) in $\mathrm{cm}$, time in msec. The shape-coefficient $\alpha$ is explained in section D1.1.

The vertical line designates the instant of opening of the opercular valves $(t=\tau)$. The shaded area indicates the motion of the prey into the mouth (first broken line: time whereby the prey passes the mouth aperture, second broken line: prey fully engulfed). The maximum errors are indicated (see Fig. 11). 
from a parallel stream (i.e. $\tan (\phi)=0.05 ; \phi$ is the angle between two streamlines having a distance equal to the dimensions of the prey, measured at the position of the prey) a prey of $1 \mathrm{~mm}$ diameter may approach a sink (a point absorbing fluid) to a distance of $20 \mathrm{~mm}$ without disturbing the flow. As the mouth aperture of a feeding fish is not a sink but an opening having about the size of a prey, contraction of the flow is unimportant relative to prey size. So the condition that the prey may be regarded as an element of the sucked water is satisfied. This is also in accordance with the observation that a suction movement in which the prey is not captured can be almost identical to a succesful feeding movement (Fig. 5).

In corners, near the bottom and when the fish picks up the prey from a substrate (see Alexander, 1969) a disturbance of the flow may occur. It is apparent that the velocities and especially the pressures in these cases may deviate considerably from the values reached in a free flow. The influence of a substrate on the flow is determined by similar criteria as those applied to preys.

A substrate close to the fish's mouth does not always disturb the flow. When e.g. a fish in that position protrudes its jaws the impulse added to the water is low (see D1.3.2). So the flow relative to the fish's mouth will be similar to the flow occurring at prey seizure in open water.

Especially in young fishes the mouth aperture seems to limit the size of the prey (Blaxter, 1963). Important protuberances of the prey as e.g. in the stickleback may prevent its capture. In such cases the disturbance of the flow is considerable and the prey can not be considered to move with the surrounding water. Vortices in the sucked flow (see C3.1) can be considered from a hydrodynamical viewpoint as preys and they must therefore also satisfy the above condition.

C3.4. The branchiostegal and opercular valves are represented by a "valve" at one end of the profile

At a certain time in the suction act the branchiostegal and opercular valves open (Plate 1, Fig. 11). This event has been incorporated in the model by a change of the boundary condition (a water velocity or a pressure) at one end of the profile, the "opercular region".

For some fish (e.g. Pterois) the valve really opens in a very short time (ca. 2.5 msec, ref. Fig. 13) forming a caudal slit. In other fish (e.g. Gadus, ref. Plate $1 G$ ) the opercular and branchiostegal valves run from caudal to rostral along the pectoral girdle. In these fishes the opercular slit is first formed caudally and then extends forward to the symphysis cleithri during a time interval of about 5-40 msec (Fig. 13). In the flatfish Platichthys the "upper" valve opens at an earlier moment (ca. $5 \mathrm{msec}$ ) than the "lower" one and the whole act is asymmetrical $($ Plate $1 \mathrm{H})$. In these fishes the model approximation of the opercular and branchiostegal valves describes only roughly the real act. An exact fitting of the valve movement in these cases would however greatly increase the amount of model parameters and it appears that also these cases can be well approximated with the present model. The choice of boundary conditions with open and closed valves is discussed in D2.3. 
FIG. 6

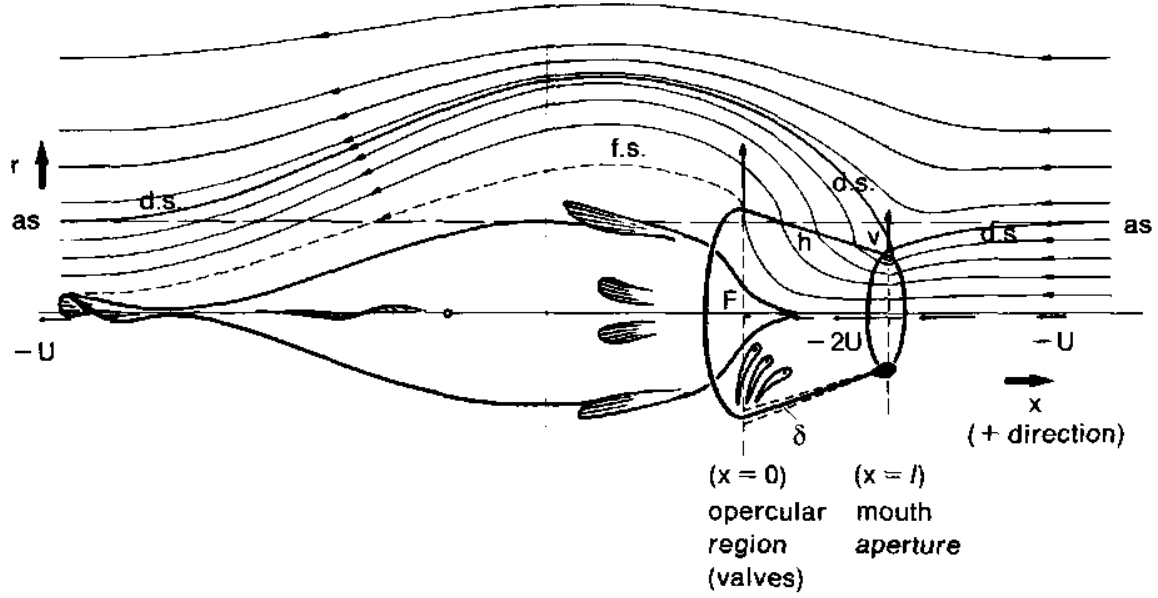

FIG. 6. Qualitative picture of the actual flow, at one instant generated by a forward moving and expanding conical profile. The friction is neglected.

The flow is shown with respect to the translating profile. The profile sucks itself forward in an earth-bound frame (i.e. in a positive direction) with a velocity $U$.

The opercular valves have been opened after initial suction with closed valves. The profile wall $(h)$ moves radially. Along the profile wall a boundary layer $(\delta)$ wherein the friction plays a role is built up. The thickness of the boundary layer is greatest in the caudal parts of the profile. In the flow picture the influence of this layer is not taken into account. The radial expansion of the profile causes a caudally directed flow through the mouth aperture. Because the profile expands streamlines are crossing the profile wall.

Outside the profile the angles between streamlines and profile wall are different from inside. Note the difference between profile motion and water motion at the wall.

In the mouth aperture the water velocity reaches its greatest value. The velocity distribution along the axis is designated by the arrows. Because the velocity decreases backwards from the mouth aperture, the angle of the streamlines inside the profile (e.g. at $h / 2)$ with the axis increases.

The gills are hydrofoil shaped and situated along the streamlines. Also the pectoral girdle is streamlined (ref. Plate 3).

The outward flow from the opercular valves creates free streamlines (f.s.). Outwards these free streamlines a higher velocity exists than inside these streamlines (i.e. more close to the axis). When the expansion-acceleration of the profile is positive, the pressure outside the free streamlines is lower than the pressure at the inner side. Thus, in the latter case the free streamlines are continuously diverging as a function of the time.

The fish's body can be inserted in the region $F$ where flow velocities are negligible.

The radius of the dividing streamline (i.e. the streamline separating the flow along the fish and the flow into the mouth aperture) has a greater value about the fish than at infinity (i.e. at the asymptote (as) caudally and rostrally of the profile), due to the expansion of the profile. In the picture this difference is exaggerated. Actually this difference in height can be neglected (see D3.3.3: footnote).

The vortex loop (v) of the flow is lying at the fish's lips. The lips are thickened and rounded off to enclose this vortex loop, thus ensuring a stable flow.

Note: the flow is highly unsteady and this picture is highly variable as a function of the time. Ref. Plate 3, 4, Fig. 21, 22. 


\section{C3.5. Flow description; from a two-dimensional to an uni-dimensional approach}

The sucking profile generates a circulating flow about it. A qualitative impression of this flow is given in Fig. 6.

It is extremely difficult to determine the vortex distribution on the profile as a function of the time and little insight is gained in the hydrodynamical demands determining fish head construction. Therefore we have split the problem into three sub-problems: the flow inside the mouth cavity, the flow in front of the mouth aperture and the caudal flow from the opercular slits. For the interior problem the applicability of the model is subjected to the condition that the ratio of the squares of mouth height and mouth length is small.

This condition i.e. that $h^{2}<<l^{2}$ is discussed in Muller et al. (1982, formula (6)). As argued above, condition C3.2 (rot. symm.) allows a two-dimensional approach of the problem. When $h^{2}<<l^{2}$ the velocity in the $x$-direction is constant over the radius and the flow inside the mouth is approximated by a parallel stream. In that case the two-dimensional problem is reduced to an uni-dimensional in the direction of the long axis of the fish. Table I gives a survey of $h^{2} / l^{2}$. These data show that the application of uni-dimensional equations is justified and the errors in calculated velocities and pressures are less than $10 \%$ for most of the fishes.

Another condition is that the influence of the gills on the flow is neglected. During respiration the tips of neighbouring hemibranchs generally touch each other and so form the gill curtain. This curtain functions during respiration as a variable resistance between opercular and buccal cavity (Ballintijn, 1968). Lauder $(1980 \mathrm{a}, \mathrm{b})$ suggests that a variable resistance of the gills plays a key role in the suction process. That this cannot be true is discussed in Muller et al. (1982). Model calculations and flow measurements indicate that during suction there exist only a caudally directed flow over the gills (see D2.4, D3.2). During suction the hemibranchs are folded together (Plate 1, Plate 2G and Muller et al., 1982: Fig. 9B) and the cross-section of these structures is then hydrofoil-shaped thus providing a minimal resistance to the caudally directed flow (Plate 3). A reverse flow resulting from a high pressure difference between buccal and opercular cavity as Lauder $(1980 \mathrm{a}, \mathrm{b})$ suggests, would cause the hemibranchs to move in an uncontrolled way resulting in damage of these delicate structures.

Lauder (1980 a, b) assumes that a reverse flow occurs through the gill curtain initially during suction. This however is in contradiction with his assumption of a high gill resistance at these instants (Lauder, 1980 b, p. 67: conclusion (1)). At the same time this author argues that the gills prevent a flow from caudal to rostral and that the gill cover has to function "mostly as a passive element preventing the posterior influx of water." (Lauder 1980 b, p. 69).

We prefer to consider the gill cover as the only structure necessary to prevent inflow from caudal into the opercular cavities. Besides it importantly contributes to suction (see D2). However we do not exclude any influence of the gills on the flow.

We suggest that the gills do not possess an active or passive function as a part 
of the suction mechanism but that they merely form a resistance to the flow as any body inserted in the flow would do. This resistance is minimized in fish species where an unhampered flow is very important (e.g. Macrorhamphosus, see Osse and Muller, 1980). Although a quantitative estimation of the error through neglect of the influence of the gills cannot be given, the velocity- and pressure waveforms as experimentally found in a sucking fish mouth are also generated by the model without assuming any influence of the gills (D4.2, D4.3 and Van Leeuwen and Muller, in prep.).

C3.6. Approximations for the external flow in front of the mouth aperture and caudal of the opercular slits

As already explained it is difficult and of little help to determine the vortex distribution about the moving profile. However an accurate description of the flow in front of the fish's mouth aperture is necessary for two reasons viz. to

FIG. 7

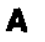

Suction: light fish

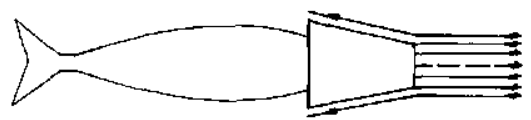

B Suction; heavy fish

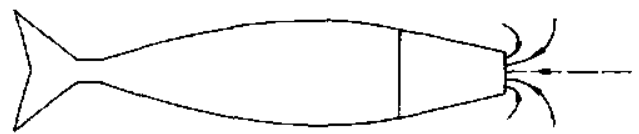

C

Swimming; valves closed

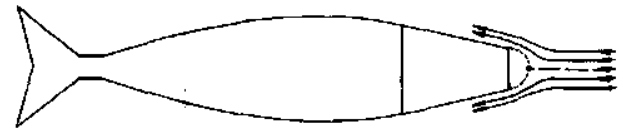

D

Swimming;

valves open

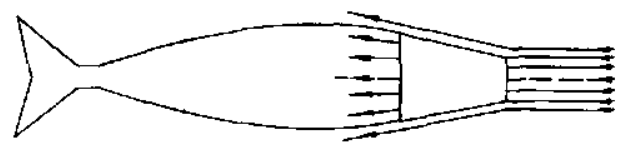

FIG. 7. Schematical drawings of the flow relative to the fish by different combinations of suction and swimming. Between these extremes continuous ranges of options exist. Note the different hydrodynamical conditions with valves closed (A--C) or open (D). A: Light fish sucking itself considerable forward. The flow relative to the fish is the opposite of the fish's motion in an earth-bound frame and therefore a parallel stream. So, the flow is highly directed.

B: Heavy fish sucking itself hardly forward. Because the fish's body does not move much, water is sucked from all directions (vortex flow).

C: Swimming fish with closed valves. The fish does not suck and therefore pushes water away from its mouth aperture. The prey can not be captured.

D: Swimming fish with open valves. The water can flow freely through the opened mouth tube. So the flow is a parallel stream and feeding occurs by filtering.

Refer also Fig. 21 . 
determine a boundary pressure for the flow inside the mouth and to understand the shape of the flow observed in movies during the fish's suction act.

The first purpose is satisfactorily solved by representing the mouth aperture as either a parallel stream, a sink, a dipole or a circular vortex filament (Muller et al., 1982: Fig. 3). The choice of a particular streamline pattern appeared to be of minor influence on the pressure calculated in the mouth aperture.

The flow in front of the fish's mouth is adequately described by a circular vortex filament lying at the fish's lips and thus moving with the fish.*

A simpler description of the flow by a parallel stream, a sink or a dipole has two serious disadvantages viz. the radius of the mouth aperture is difficult to define and singularities in the flow are present at the most important points. Therefore the suction strength of the external flow is difficult to derive from the internal flow in the latter representations of the flow.

As the fish swims and sucks itself forward the circular vortex filament at the mouth aperture moves in an earth-bound frame.

With other words: relative to the frame with an origin lying at the fish's mouth aperture, the vortex is combined with a parallel stream. Depending on the ratio between the strength of the vortex and the parallel stream water is sucked from all directions (when the fish stands still or is only slowly moving) or from a restricted tube-like area when the fish aims at the prey during a sudden dart (Fig. 7).

The ratio between the forward velocity of the fish due to suction and the water velocity in the mouth aperture in an earth-bound frame depends on respectively the mass of the fish, the mass of the moved water (because the impulses of both fish and water are equal) and also on preceding suction events.

The swimming velocity of the fish has to be added to the forward velocity due to suction only. Different combinations of swimming and suction produce the conical flow mentioned above or stagnation effects. So the ratio between the translation velocity of the vortex filament and the water velocity in its centre (in an earth bound frame) is a function of the time (see D3). Taking this ratio as a constant one obtains fundamental insights in the terms making up the pressures e.g. positive pressures in the opercular cavities due to acceleration of the fish when the suction starts (ref. D4).

A sucking fish takes advantage of swimming only if the swimming motion is of the same order of magnitude as the translation due to suction. A relative small swimming motion does not importantly contribute to the capture of the prey; relative fast swimming movements decrease the region in which the prey can be captured (see Muller et al., 1982). An important possibility is to capture the prey by very fast swimming with open mouth and opercular valves (Nyberg, 1971). This does not occur because in such cases the advantage of the previous suction is not fully exploited to capture the prey (Fig. 7, section D3.3.4). It ap-

* The vortex filament moves over the profile in a caudal direction when the caudal end of the profile expands and the rostral end compresses (or the reverse case). As this occurs e.g. in the mouth closing phase and not during prey suction, in this paper no account is taken for this effect (for description, see Van Leeuwen (in prep.)). 
pears thus to be possible to derive from the suction movements demands and limitations for the additional swimming motion. This approach, whereby no extra parameters of swimming need to be introduced, is treated in detail in D3.3.

The flow behind the opercular slits is bound by a free streamline sheet because water is flowing outward from an aperture (Muller et al., 1982; D3.4).

\section{C3.7. The adequacy of the model after simplification}

Now it is appropiate to estimate the reality value of the model in its entirety. The errors in the model calculations are less than $2 \%$.

The errors introduced by the simplifications: frictionless flow, rotational symmetry, prey as an element of the sucked water, rest situation at $t=0$ (in the moving frame), no influence of substrates or other obstruction of the flow, small height-length ratio, cylinder or cone, circular vortex, the effect of swimming and forward suction and finally the variation of the external flow during suction can be judged for each of them in different cases as demonstrated above.

The determination of the profile excursions, the influence of the gills, the definition of the caudal valve and the boundary condition at the opercular slits and (visco)-elastic properties of the fish's head may lead to errors difficult to quantify. The good agreement between model predictions and experimental results (e.g. Plate 1, 3, 4, 5, Fig. 13, 17, 19, 22, 25) prove that notwithstanding the simplifications the model provides a reliable and necessary tool to compare types of suction feeding in the whole series of fishes.

Analogous approximations used in aero- and hydrodynamics to predict complex flow around aeroplane wings and ship profiles have also proven to be very useful (see e.g. Verhagen, 1967).

\section{C4. OUTLINES OF THE MODEL.}

This section gives a description of the model parameters being used and refers to a more formal mathematical description given in Muller et al. (1982).

The model of the fish sucking a prey consists of a cylindrical or conical profile $h(x, t)$ of length $l$, moving with a frame of cylinder coordinates $\{x, r\}$.

The radial motion of the profile is defined by a function of the time (see Appendix I) representing an expansion followed by a compression of the profile. At $x=0$ (the "opercular region") and $x=l$ (the "mouth aperture") the motion functions, respectively $h(0, t)=h_{2}$ and $h(l, t)=h_{1}$, are chosen independently of each other. As a result of the radial motion of the profile a flow is generated. The velocities occurring in this flow i.e. inside the profile follow from the equation of continuity (i.e. the filling of the profile).

Thus these velocities can be described relative to the frame of this profile (i.e. $\{x, r\}$ ). As a result of the suction (also swimming may occur) the profile itself translates along its axis (i.e. in an earth-bound frame). So the motion of the water in an earth-bound frame can be determined by adding the forward movement of the profile measured in an earth-bound frame and the velocities calculated relative to the profile as a result of the radial motion. The frame with its 
origin in the fish's mouth aperture is called the fish's frame and thus forms a moving system of coordinates.

The radial movements of the profile generate a flow characterized by a velocity $u(x, t)$ and a pressure $\Delta p(x, t)$. The velocity at $x=l$ (mouth aperture) is $u(l, t)$. In order to couple the water velocities with respect to the fish $(u(x, t))$ and the water velocities occurring in the earth-bound frame, we call the velocity at the mouth aperture in the moving frame $u(l, t)=u_{1}$.

The suction flow causes the profile to translate in an earth-bound frame with a velocity $U$. Also swimming may contribute to $U$. The water velocity in the mouth aperture is represented in the earth-bound frame by $u_{m}$. This is the actual velocity of the water. The relation between the water velocity $u_{1}$ in the moving frame and the water- and profile velocities in the earth-bound frame is $u_{1}=u_{m}-U$.

When suction is combined with forward translation a point of zero flow inside the profile can occur in an earth-bound frame. This is further discussed in D4.2.

At the mouth aperture of the fish $(x=l)$ a circular vortex filament with radius $h_{1}$ is situated. The flow of this vortex is only considered in and in front of the mouth aperture. The description of the flow pattern in front of the mouth aperture is valid for $U \geq 0 . u_{m}$ may in that case have any value (see D3.3).

At $x=0$ a valve ("opercular and branchiostegal valve") has been constructed, which opens at an instant $t=\tau$, depending on boundary conditions chosen or derived from water velocity or pressure. The flow behind the opercular slits $(x \leq 0, t>\tau)$ is bound by a free streamline sheet.

TABLE II. Input parameters and output quantities of the model. INPUT PARAMETERS:

\begin{tabular}{|c|c|}
\hline $\begin{array}{l}h_{1 \text { nul }} \\
h_{1 \max } \\
\alpha_{1} \\
t_{h_{1 \max }} \\
t_{\mathrm{vI}}\end{array}$ & $\begin{array}{l}\text { zero radius of "mouth aperture". } \\
\text { maximum radius of "mouth aperture". } \\
\text { shape coefficient of "mouth aperture". } \\
\text { time at which } h_{\text {imax }} \text { is reached (from } t=0 \text { ). } \\
\text { delay time of "mouth aperture" expansion. }\end{array}$ \\
\hline $\begin{array}{l}h_{2 n u l} \\
\text { etc. }\end{array}$ & idem, for "opercular region (valves)". \\
\hline $\begin{array}{l}l \\
\mathrm{a} \text { or } \mathrm{b}\end{array}$ & $\begin{array}{l}\text { mouth length. } \\
\text { ratio between translation of fish and water velocity in the mouth aperture in an } \\
\text { earth bound frame. }\end{array}$ \\
\hline$\tau$ & $\begin{array}{l}\text { time of opening of opercular valves. } \\
\text { time at which the mouth aperture is closed again. }\end{array}$ \\
\hline
\end{tabular}


FIG. 8

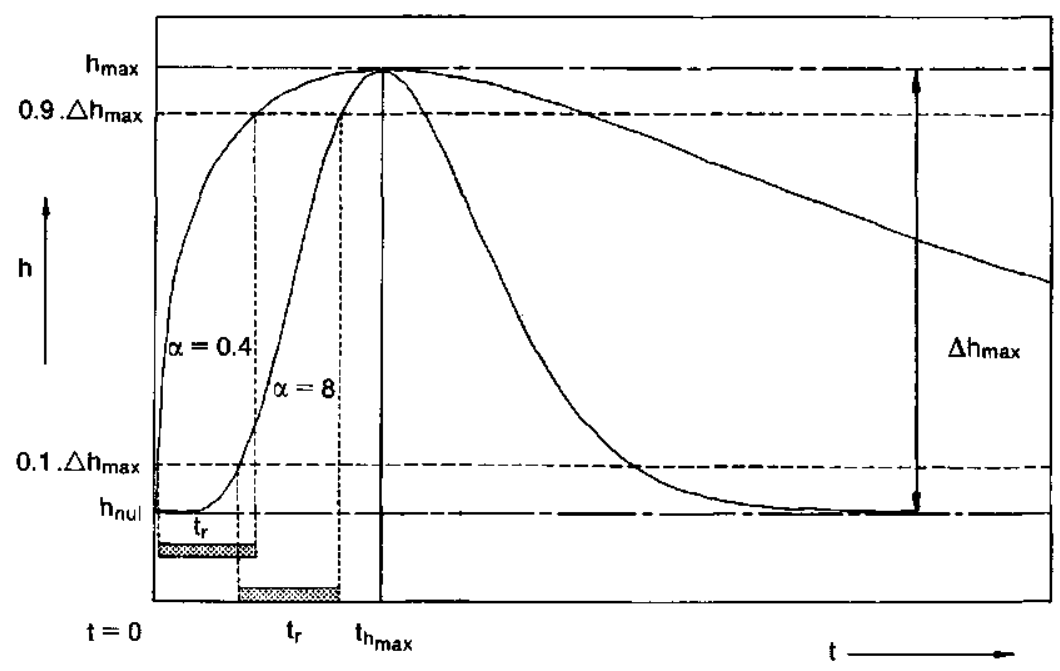

FIG. 8. Graph of profile expansions showing the equal risetime $\left(t_{r}\right)$ with different parameters $\alpha$.

Two different shapes can be distinguished. The transition between the two is reached for $\alpha=2.0$. The picture also demonstrates the difference in local curvature of the curves being the difference in local accelerations.

$h=$ profile radius, $t=$ time, $\alpha=$ shape coefficient. Further explanation in text (section D1.1).

A survey of the input parameters of the model is given in Table II. Model calculations produce the water velocities and pressures as a function of position and time, without and with opening of the opercular valve. The model is as far as pressure-calculations are concerned only valid for uni-directional flow $\left(u_{m} \leq 0, U \geq 0\right.$; see also D3.2, D4.2).

\section{Results.}

\section{D1. Profile Form AND -MOVEMENT.}

\section{D1.1. Definition and determination of profile excursions}

In the model a profile excursion is determined by three parameters: 1) The difference between the maximum profile radius and the profile radius at rest $\left.\left(\Delta h_{\max }\right), 2\right)$ The time interval (measured from an instant $\left.t=0\right)$ in which the maximum profile radius is reached $\left(t_{h_{\text {max }}}\right)$, and 3) A parameter $\alpha$ defining the shape of the movement curve (Fig. 8).

The problem is to determine these parameters accurately enough to calculate velocities and pressures from the movements registered on the film.

When $\Delta h_{\max }$ and $t_{h_{\max }}$ are kept constant, a low value of $\alpha($ i.e. $\alpha<2)$ causes 
the profile to expand with a steep slope which diminishes towards the maximum excursion.

At a high value of $\alpha$ (i.e. $\alpha>2$ ) the profile starts to expand very slowly, followed by an abrupt expansion just before $t=t_{h_{m} /}$. The risetime of the movement (defined as the period in which the profile expands from $h_{n u l}+1 / 10 . \Delta h_{\max }$ to $\left.h_{n u l}+9 / 10 . \Delta h_{\max }\right)$ can be the same for two movement curves characterized by both a low and a high value of $\alpha$ (Fig. 8). This implies that the average velocities of the water, generated during the expansion phase of these curves have a comparable magnitude. Because the second derivative of these two movement curves is different, the peak velocities of the water and the pressures considerably deviate from each other (see below, Fig. 10).

The parameters $\Delta h_{\max }$ and $t_{h_{\max }}$ can be measured directly from the films. The parameter $\alpha$ must also be determined. This was done by a least-squares approximation to the measured movement graph over a chosen time interval. The choice of the interval depends on the attention which one wishes to pay to a certain part of the graph.

Mostly only the ascending flank of the graph has been fitted (i.e. from $t=0$ to $t=t_{h_{\max }}$ ) because the most relevant part of the suction process takes place during the expansion of the fish's mouth. When movements in the buccal region were considered $(x=l)$, the graph was fitted from e.g. $t=0$ to $t=\tau$ (valve opening), or till $t=4 . t_{h_{\max }}$ (the end of the movement) or till the prey has been engulfed. In this way most of the measured graphs could be accurately approximated (i.e. within the errors of the measurements). Therefore the proposed formulation of the profile movements is adequate (Fig. 11).
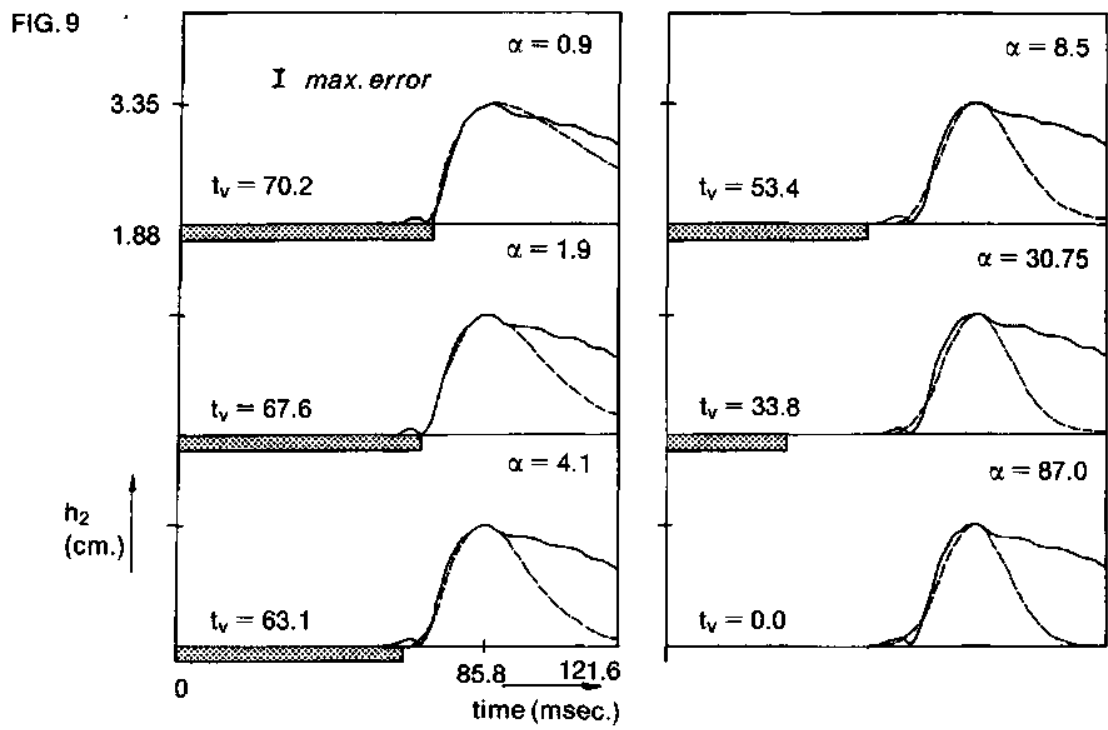

FIG. 9. Opercular excursion $\left(h_{2}\right)$ of Pterois fitted with different pairs $\alpha_{2}$ and $t_{v 2}$. Excursions (ordinate) are in $\mathrm{cm}$, time in msec. Further explanation in text (section D1.1). 
When a least-squares approximation to a movement graph is made over the time interval $\left[0, t_{h_{\text {max }}}\right]$, the obtained value of $\alpha$ depends strongly on the choice of the time point $t=0$. As this is undesirable the following procedure was carried out:

First, the parameters $\Delta h_{\max }$ and $t_{h_{\max }}$ were considered to form together a single parameter i.e. the point of maximum fish head excursion. The length of the time interval $\left[0, t_{h_{\max }}\right]$ is thereby not important but the whole ascending flank of the fish's head movement must be included in this interval. Second a delay time $t_{v}$ was defined being the time after $t=0$ where the part of the curve characterized by $\alpha$ starts, lying in $\left[0, t_{h_{\text {max }}}\right]$.

The fish's movement graph was now approximated with the least-squares method over the time interval $\left[t_{v}, t_{h_{\text {max }}}\right]$ for different values of $t_{v}$. In this way the movement graphs could be fitted, within the region of reliability of the measurements, with a set of curves characterized by a fixed combination of the parameters $\Delta h_{\max }$ and $t_{h_{\max }}$ and, for each curve, a pair of the parameters $\alpha$ and $t_{\mathrm{v}}$.

The movement curve is thus again determined by three parameters but the shape of the ascending flank can yet be varied independently of the risetime (Fig. 9).

That this is essential to calculate the pressure properly is shown in Fig. 10. The broad pressure range due to varying $\alpha$ implies that it is impossible to find the actual value of $\alpha$ from the measured movement only although the mathematical description of the movement graphs is valid. As pressures are essentially second derivatives of motion the fitting of the movement graphs should be carried out on the level of the accelerations. It is apparent that accelerations can not be deduced from distances measured in movie frames due to the large errors made in the measurement of the displacement data. Also e.g. Webb (1975) does recognize this. However he omits the range of errors in the accelerations he obtains.

Also accelerometer measurements will give rise to considerable errors because they influence the fish in its predatory behaviour, influence the acceleration of the head part on which they are mounted and because they are highly directional sensitive.

Lanshammar (1982) demonstrates the validity of the determination of even second derivatives from motion curves. However the data he uses are far more accurate than could be achieved in this study and in Van Leeuwen (in prep.).

A solution to obtain a proper model simulation of a suction act is to fit the fish's movements, to measure the pressure and to adjust by trial and error the profile movements until the measured pressure and the calculated pressure are in concordance with each other. As this procedure appears to be successful the model approximation is proven to be valid for the particular suction process and can be taken as a starting point for simulations by parameter variation.

Summarizing the following conclusions are drawn:

1) The head movements carried out by the fish during feeding are satisfactorily described by the proposed profile movements.

2) The description of a profile movement requires at least three parameters. Introduction of a fourth parameter enables a choice of the shape of the movement 
FIG. 10

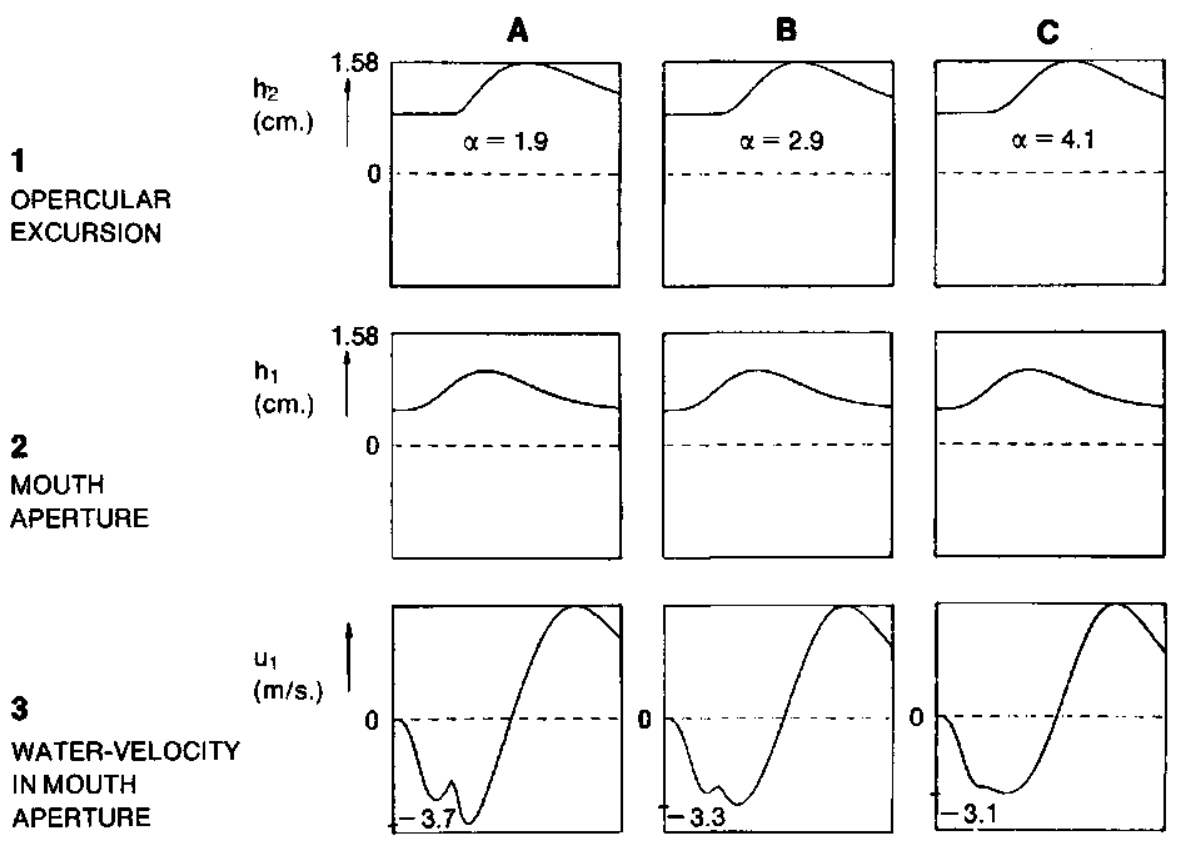

4

OPERCULAR

PRESSURE

(VALVE CLOSED)
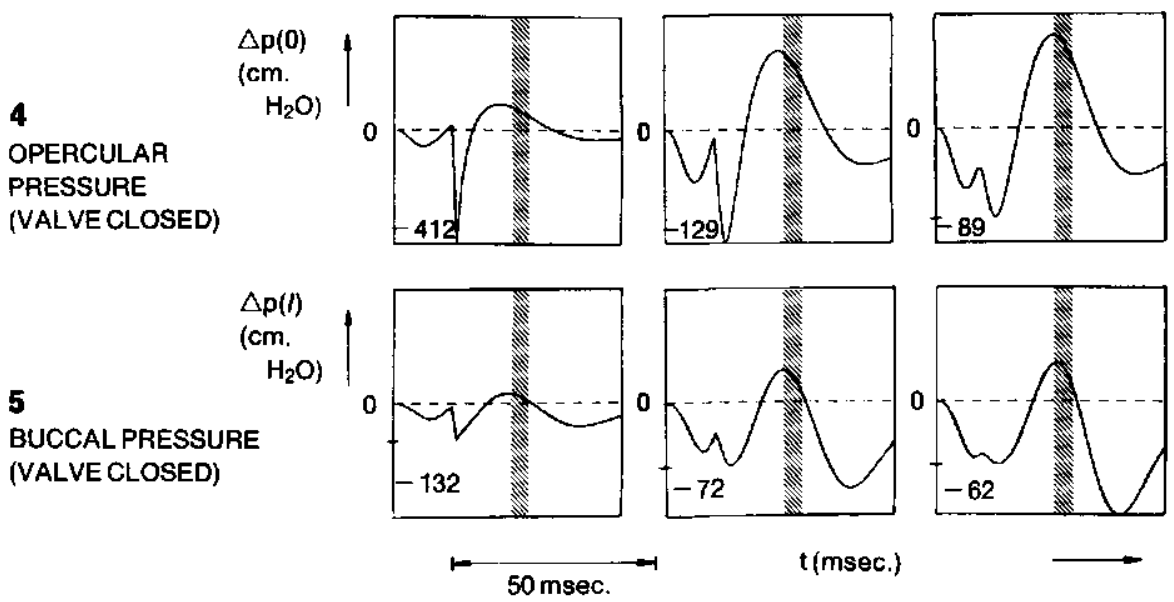

FIG. 10. Velocities and pressures generated by three profiles identical in buccal movement and differing from each other in the parameter $\alpha_{2}$ (opercular movement).

Although the movements are almost identical and the velocities are only slightly different, the pressures deviate considerably in shape and magnitude. The parameter $a$ (see sections $\mathrm{C} 4$ and D3.3) has the value 5. The cross-hatched bars denote the time after which pressure calculation is unaccurate.

$h_{1,2}=$ profile radius $(\mathrm{cm}), u_{1}=$ water velocity in mouth aperture $(\mathrm{m} / \mathrm{sec}), \Delta p=$ pressure ( $\mathrm{cm} \mathrm{H}_{2} \mathrm{O}$ ), $t=$ time (msec), $\alpha=$ shape coefficient. 
A

$\mathbf{B}$

C

D
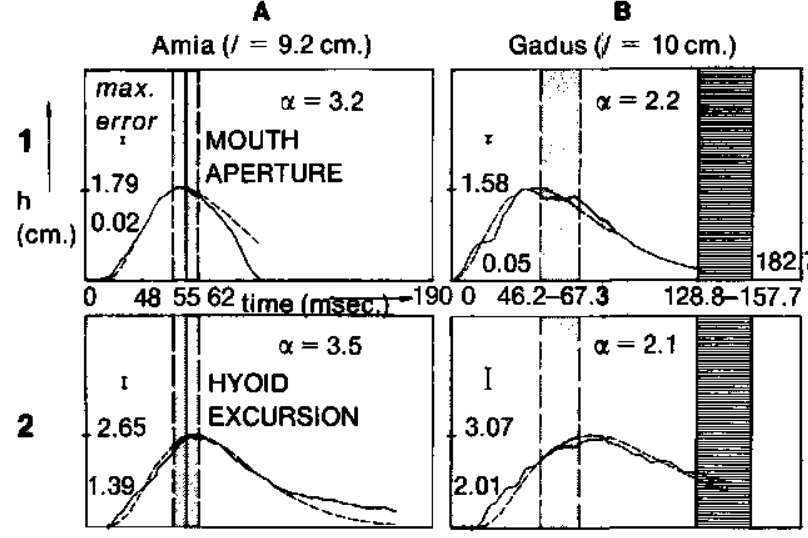

Stizostedion $(l=9 \mathrm{~cm}$.)

Pterois $(/=4 \mathrm{~cm}$.)
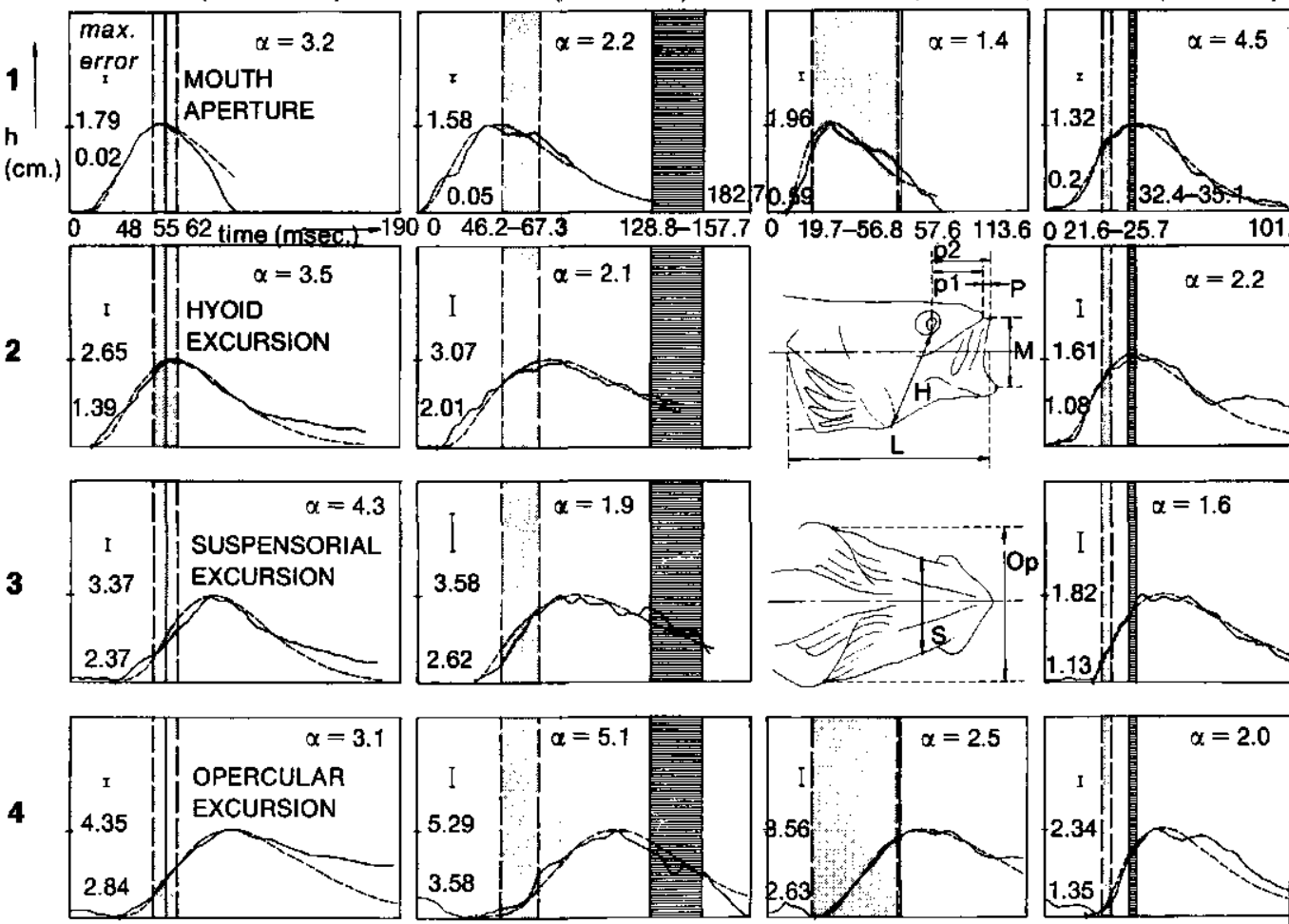

FIG. 11. Movement graphs (-) and fitted movement curves $(--)$ of the feeding of some fish species. Dimensions (ordinate) are in $\mathrm{cm}$, time is in msec. Time of opening valves: continuous lines or hatched area. Motion of prey into mouth aperture: dotted areas within broken lines (ref. Fig. 5). In the pictures B the line $157.7 \mathrm{msec}$ indicates the time at which the valves are halfway open. In the other pictures the corresponding lines designate the situation: valve fully open. Maximal errors indicated by vertical bars. Note the striking resemblance between theoretical and actual curves and initial adduction of the operculars.

Note that even these detailed motion graphs are inadequate to demonstrate the essential features of suction feeding (type of flow, role of swimming, relation movement -- preycapture, opening of the valve a.o.). Therefore further analyses are given in Fig. 3, 12, 13,17 and 22 .

The parameter $\alpha$ (shape coefficient) is determined according to section D1.1. $l=$ mouth length.

The parameters measured from the movie frames are indicated in the drawings of a fish head: $L=$ mouth length, $H=$ hyoid excursion, $M=$ diameter of mouth aperture, $S=$ suspensorium excursion, $O p=$ operculum excursion, $P=$ protrusion length, $P=p_{2}-p_{1}$. These values are also used in other figures and calculations. Refer also to Plate 1. 
m)
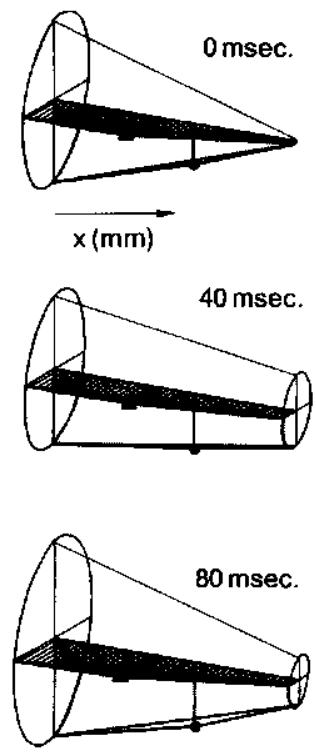

$120 \mathrm{msec}$.

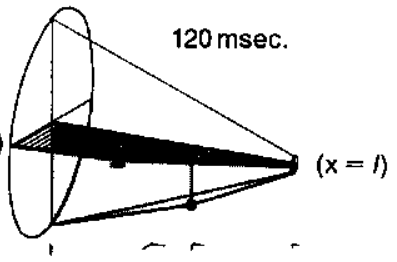

o

S $\mathrm{H}$

M

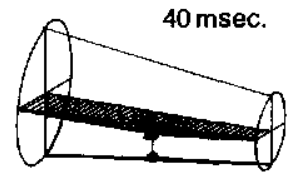

0 msec.
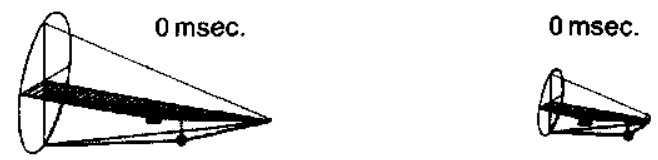

$40.3 \mathrm{msec}$.

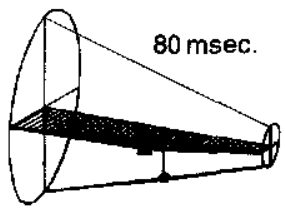

$67.2 \mathrm{msec}$.
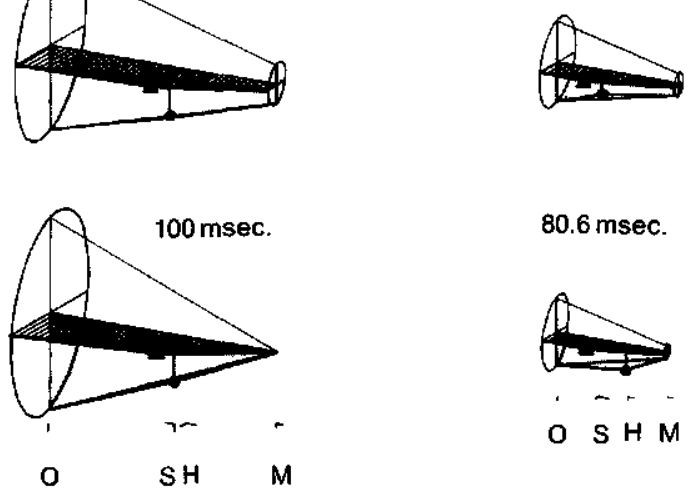

80.6 msec.

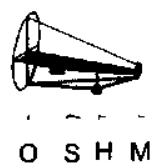

FIG. 12. Cone form of the fish's head at different times as determined from film frame analysis.

Dimensions (ordinate and abscissa) in $\mathrm{mm}$, time in msec. In $x=0$ the opercular radius is drawn, in $x=l$ the mouth aperture radius. The dots represent the radius at the hyoid, the triangles the suspensorial radius.

The maximum errors are indicated by horizontal and radial bars at the corresponding points with the marks $\mathrm{O}, \mathrm{S}, \mathrm{H}, \mathrm{M}$ to designate errors in respectively opercular-, suspensorial-, hyoid- and mouth-aperture excursions.

The graphs $A$ and $C$ are corrected for the width of the hyoid (respectively 6.4 and 3.2 $\mathrm{mm})$. Note the motion of the hyoid in $\mathrm{B}$ and $\mathrm{C}$ and the protrusion in $\mathrm{C}$.

The cone form is apparently a satisfactory description for the fish's mouth. Besides, the graphs demonstrate the rotational symmetry at the suspensorium-hyoid level.

$h=$ profile radius, $l=$ mouth length, $x=$ position inside the mouth along its axis, $t=$ time. 
curve independently of its risetime.

3) Because pressures are composed of the second derivative of motion it is impossible to predict peak values of water velocities and pressures from measured fish head movements.

Some examples of actual motion curves of different fish species together with the fitted profile excursions are shown in Fig. 11.

\section{D1.2. Corrections for the shape of the profile (Fig. 12)}

When the fish starts to suck, its mouth is not yet rotational symmetric but elliptical (Plate 1C, Fig. 3). Hence vertical measurements of the initial mouth aperture radius may give too small an estimate of the profile radius $h_{1}$ (see Fig. 11).

Tiny variations in mouth aperture cause enormous variations in velocities and pressures. Therefore a correction for the initial mouth aperture radius $\left(h_{1 \text { nul }}\right)$ has been made by making areas of the mouth apertures of fish and profile equal at $t=0$. With an approximation of the fish's mouth aperture by an ellipse the correction becomes $h=\left(r_{1} r_{2}\right)^{\frac{1}{2}}\left(r_{1}, r_{2}\right.$ : radii of ellipse of mouth aperture). With this correction calculated values of initial pressure and velocity agree much better with measured values (Table III; Van Leeuwen and Muller, in prep.).

Other necessary corrections dealing with details of fish-model differences are 1) a correction of the profile radii for the difference between outer and inner dimensions of the fish's mouth, 2) a correction for the depression of the mouth bottom (hyoid; Fig. 12) and 3) a correction for the "dead volume" formed by the gills. The latter correction is necessary because the actual caudal transverse area available to the flow is decreased by the gills. So the pressures occurring at the beginning of the suction process are more realistic and more extreme when this influence of the gills is taken into account.

This is done by e.g. reduction of the profile radius in the opercular region $\left(h_{2 n u l}\right)$.

TABLE III. Three simulations of the suction process of Amia showing the values of the water velocity in the mouth aperture and the buccal pressure. Note the dramatic decrease of the pressure values when the mouth aperture is adapted to a more real value $(108 \rightarrow 109)$.

Real peak pressures measured with a Millar transducer during the suction act of Amia: ca. 100 $\mathrm{cm} \mathrm{H}_{2} \mathrm{O}$ (buccal and opercular pressure). Further explanation in text (section D1.2).

$h_{\text {Inul }}=$ zero value of mouth aperture radius,

$h_{l \text { max }}=$ maximum value of mouth aperture radius,

$h_{\text {2nul }}=$ zero value of opercular radius,

$h_{2 \max }=$ maximum value of opercular radius,

$u_{\nu}=$ first peak of the water velocity with closed valves at $0.8 l$,

$\Delta p_{v}=$ first peak of the pressure at $0.8 l$.

\begin{tabular}{|c|c|c|c|c|c|c|}
\hline Code & $\begin{array}{l}\mathbf{h}_{\text {Inul }} \\
(\mathrm{cm})\end{array}$ & $\begin{array}{l}h_{\max } \\
(\mathrm{cm})\end{array}$ & $\begin{array}{l}h_{2 n u l} \\
(\mathrm{~cm})\end{array}$ & $\begin{array}{l}h_{2 \max } \\
(\mathrm{cm})\end{array}$ & $\begin{array}{l}u_{v} \\
(m / s)\end{array}$ & $\begin{array}{l}\Delta p_{v} \\
\left(\mathrm{~cm} \mathrm{H} H_{2} \mathrm{O}\right)\end{array}$ \\
\hline 100108 & 0.10 & 1.88 & 2.89 & 4.40 & -6.3 & -6088 \\
\hline 100109 & 0.50 & 2.28 & 2.89 & 4.40 & -4.3 & -391 \\
\hline 100116 & 0.50 & 1.80 & 2.69 & 4.20 & -3.0 & -202 \\
\hline
\end{tabular}


Table III presents a model simulation of an Amia-like profile without and with account taken for the corrections mentioned. All the above corrections fitting the model to the actual fish profile are executed within the maximum error of the measurements taken from the movies. These errors are indicated by vertical bars in all the figures.

\section{D1.3. The opercular and branchiostegal valve}

D1.3.1. Opening of the valve; consequences for fish head morphology and flow direction

When the opercular and branchiostegal valves open up the water may flow caudally or enter the opercular cavities through the opercular slits formed (in the fish's frame). As shown in D2.3 a caudally directed flow at the opercular slits considerably enlarges the flow into the mouth aperture and so the chance to capture the prey is greatly increased.

These expectations gained from hydrodynamical considerations are confirmed by studying the morphology of the fish's head. Such features are: the rounded off lips of the fish providing a turbulence free flow into the mouth aperture (Osse, 1969), the hydrofoil shaped gills adapted for minimal resistance for a caudally directed flow (see D3.2). The caudal thinning of the operculars and the acute edges of the opercular and branchiostegal valves eliminate stagnation points.

Also the pectoral girdle is streamlined in a caudal direction. All these features suggest that the fish strives to generate an unidirectional flow during its suction act without turbulences.

The time course and magnitude of this flow, primarily determined by the movements of the head and swimming movements, can be controlled by choosing the time of opening of the opercular valve (see D2.3). In this way the suction process can be attuned to specific situations.

That the maintenance of this caudally directed flow is the only sensible way to solve the fish's problem is apparent. Suppose that a rostrally directed flow occurs inside and relative to the fish's mouth. Then the resistance of all the elements mentioned above would vary in a highly uncontrolable way thus hampering the flow, causing much turbulences, and so greatly reducing the water velocity into the mouth aperture and successful prey capture.

\section{D1.3.2. Observed feeding types, their profile form and movement}

In Fig. 13 the time of opening of the opercular and branchiostegal valves $(t=\tau)$ is plotted against the time of maximal opercular abduction $\left(t_{h_{2} \max }\right)$ for a number of suction movements of different fish species.

This diagram demonstrates the restricted timing wherein a fish carries out its various movements during suction. It shows that the opercular and branchiostegal valves do not open at an arbitrary instant during expansion but that this instant is determined. Individuals with a certain age and size of a particular fish species have a particular feeding pattern to capture a certain type of prey. 
FIG. 13

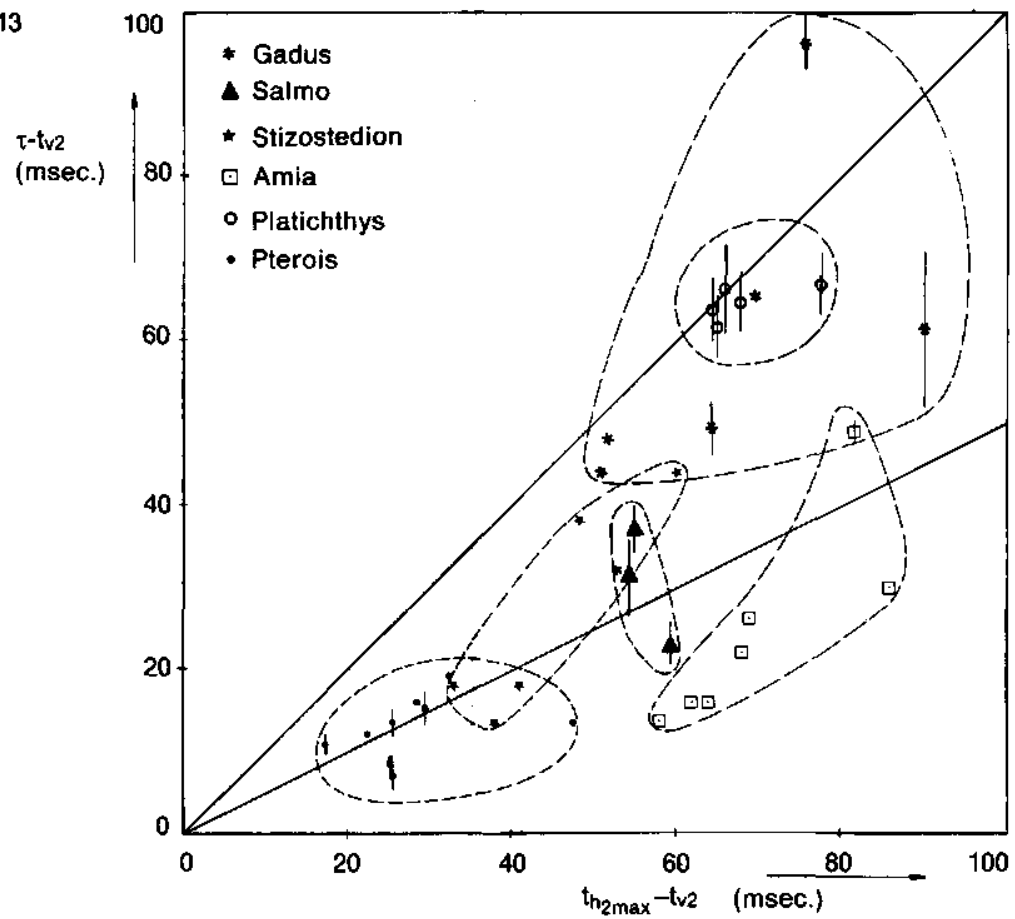

FIG. 13. Diagram showing the relation between the time of opening of the opercular and branchiostegal valves $\left(\tau-t_{v 2}\right)$ and the time of maximum opercular abduction $\left(t_{h_{2} \max }{ }^{-}\right.$ $t_{v 2}$ ). The moment of reference $t_{v 2}$ was chosen in order to refer the time of opening of the valves to the phase of the opercular abduction. In the following text this moment is always referred to.

The vertical lines indicate the duration of valve opening i.e. the period between the situation: valve just opened at a certain site to the situation: valve fully open.

Times in msec. The picture shows the determined region of valve opening for individuals of a certain age and size of a species.

Above the line $\tau=t_{h_{2 m a x}}$ suction takes place with closed valves. This occurs in e.g. syngnathids. Because the suction act in these fishes consists of two phases (viz. suction and transport of the prey) the region of $\tau$ versus $t_{h_{2 \max }}$ would move from the upper left corner of the diagram to the upper right corner (not drawn because of the large values of the concerning times; ref Plate $1 \mathrm{E}$ ).

The line $\tau=\frac{1}{2} . t_{h_{2 \max }}$ separates the feeding types high- $\tau$-suction and low- $\tau$-suction (see D1.3.1, D3.3.4). Low- $\tau$-suction ("velocity-suction") is found about and under this line; high- $\tau$-suction ("volume suction") is found above this line to the line $\tau=t_{h_{2} \text { max }}$. A continuous increasing efficiency of prey suction (see D3.3.4) is obtained starting from filtering (large $t_{h_{\text {max }}}$ ), via low- $\tau$-suction with swimming (intermediate $t_{h_{2 m a x}}: 50-200 \mathrm{msec}$ ) to low$\tau$-suction with protrusion of the jaws (low $t_{h_{2} \max }$ ). The opening of the valve appears a necessity in prey suction; the area above the line $\tau=t_{h_{2 m a x}}$ is hardly used. 
The relation with the prey has been demonstrated by Elshoud-Oldenhave (1979) for feeding movements of the pike-perch (Stizostedion).

The existence of different types of suction feeding is also apparent from Fig. 13. A comparison between Salmo (trout) and Pterois (lionfish) shows that the creation of the opercular slits in Salmo occurs at about twice the time Pterois needs. However in both species the valves open very early during the suction act, i.e. the main part of the abduction of the suspensoria and opercula occurs with open valves (Fig. 13).

By an early opening of the valves a small impulse is added to the water and the prey (in an earth-bound frame). The suction force $F$, generated by the expanding fish head and causing the water to accelerate, is only exerted during the short period between the start and $t=\left(\tau-t_{v 1}\right)$ when the valves are still closed. After the opening of the valves the fish can not generate a suction force of comparable or greater magnitude than with valves closed. The only option for the fish to manipulate the flow now is to change its head form as described in D2.3. When swimming supports suction efficiently (e.g. Salmo) the impulse added to the water may even reach zero. It is therefore advantageous for the fish to combine low- $\tau$-suction with swimming (low- $\tau$-suction was also called velocity-suction: Osse and Muller, 1980). Experiments carried out by Van Leeuwen (in prep.) show that during most snaps of Salmo a very small impulse is added to the water i.e swimming and suction compensate each other. Considerable swimming velocities together with suction result in a highly directed flow to the mouth (see D3.3). In the earth-bound frame the water in front of the mouth aperture and the prey will reach only very low velocities.

In the case of the lionfish also a small impulse is added to the water and the prey. The lionfish drives the prey in a corner or along a substrate with its enormous pectoral fins and then aims at the prey with the protruding jaws. Because of the strong and rapid protrusion of the premaxillae the flow, and so the motion of the prey relative to the mouth aperture, is also in this case highly directed (see D3.3). Thus, the rapid opening of the valves after the completion of jaw protrusion strongly reduces the suction of preyless water. A minimal impulse is spent to water, prey and predator.

An additional advantage of both ways of feeding just described is that the water in front of the fish's mouth aperture containing the prey is hardly moved and so the prey can not detect the approach of the predator by detecting the flow.

A fish without a well developed protrusion mechanism trying to catch a prey from a corner which prevents fast swimming movements has only one option left: move a large mass of water to obtain the prey. In that case the period $\left(\tau-t_{v_{1}}\right)$ is large (i.e. the valves open relatively late). This type of "volume suction" is found in e.g. Gadus (Osse and Muller, 1980). Here the impulse added to the water is great. The reduced swimming and the lack of protrusion causes a wide flow towards the mouth aperture (see D3.3) and a relative large amount of water without prey is sucked. This type of suction was observed for a large cod in a relative small aquarium.

Cod feeding in the open water also obtain their prey in the same way as the 
trout. The observation that in the above conditions a volume suction strategy is applied by the cod abundantly shows the importance as well as the adaptability of the choice of $\tau$.

\section{Dl.3.3. The construction of the gill cover as an adaptation to the type of suction feeding}

Primitive fishes (e.g. Protacanthopterygii, Elopiformes and Clupeiformes), possessing valves of plate-like, non-rotatable branchiostegal rays (McAllister, 1968), cannot keep their valves closed over a great abduction of suspensoria and opercula and feed by filtering (e.g. Engraulis) or low- $\tau$-suction with swimming (e.g. Salmo).

When the branchiostegal rays become aciniform and rotatable (as in the Paracanthopterygii) also high- $\tau$-feeding is possible (e.g. Gadus). So an extra option for feeding is added due to the valve construction.

With such a highly developed branchiostegal apparatus and the development of a protrusion mechanism as e.g in Acanthopterygii another feeding type viz. low- $\tau$-suction with protrusion is possible (e.g. Pterois). So a gradual increase of choices of feeding types is gained.

In the region in Fig. 13 where $t_{h_{2 \max }}$ is very small suction is often combined with dorso-rotation of the snout. An example of such a mechanism is found in syngnathids. In e.g. Entelurus (Plate 1E) the suction act consists of two separate phases:

1) a phase wherein a very rapid expansion of the head goes together with an extreme levation of the neurocranium (about 13 degrees) and so a dorso-rotation of the fish's snout. In this phase the prey is caught.

2) A phase wherein the prey is transported from the snout tip to the oesophagus. $t_{h_{2 \max }}$ is reached very late and the "valves" are in this extreme case opened a long time after this moment. So Entelurus sucks in fact with permanently closed valves. These "valves" in this species are grown together with the pectoral girdle leaving only a minute aperture for respiration.

Other long snouted fishes (Centriscidae, Macrorhamphosidae) probably open their valves very rapidly and thus combine the rapid dorso-rotation of the head with low- $\tau$-suction.

In Table IV a survey of the different types of suction described above with functional and morphological parameters is given. As is apparent from Fig. 13 these cases are extremes in a continuous range of options. Some other implications of the different types of suction will be treated later (D3.3).

\section{D2. Velocities; MAGNITUde AND DIRECTION.}

The following will give some insight in the determination of the water velocity inside the profile as a function of position and time.

D2.1. Cylinder with closed valve (Fig. 14)

Consider a cylindrical profile in its own frame of coordinates with a perman- 
TABLE IV. The most important extreme types of suction. Between these extremes a continuous range of options exist. This survey concerns the general line of advancement found in the teleosts. Other extreme specializations are also possible (see section D3.3).

\begin{tabular}{|c|c|c|c|}
\hline $\begin{array}{l}\text { Functional } \\
\text { criteria }\end{array}$ & $\begin{array}{l}\text { low- } \tau \text {-suction } \\
\text { with swimming }\end{array}$ & $\begin{array}{l}\text { low- } \tau \text {-suction } \\
\text { with protrusion }\end{array}$ & high- $\tau$-suction \\
\hline \multirow{3}{*}{$\begin{array}{l}\text { opening valve } \\
\text { phase difference } \\
\text { between buccal and } \\
\text { opercular expansion } \\
\text { role of swimming } \\
\text { field of fow in } \\
\text { the frame of the fish } \\
\text { habitat }\end{array}$} & $\begin{array}{l}\text { early } \\
\text { very small }\end{array}$ & $\begin{array}{l}\text { early } \\
\text { small }\end{array}$ & $\begin{array}{l}\text { late } \\
\text { big }\end{array}$ \\
\hline & $\begin{array}{l}\text { great } \\
\text { very directed }\end{array}$ & $\begin{array}{l}\text { small } \\
\text { very directed }\end{array}$ & $\begin{array}{l}\text { variable } \\
\text { undirected }\end{array}$ \\
\hline & open water & $\begin{array}{l}\text { from corners, } \\
\text { from bottom } \\
\text { with obstacles }\end{array}$ & $\begin{array}{l}\text { open water, } \\
\text { from corners } \\
\text { or bottom }\end{array}$ \\
\hline \multicolumn{4}{|l|}{$\begin{array}{l}\text { Morphological } \\
\text { criteria }\end{array}$} \\
\hline profile form & cylinder-like & cyl. or cone & cone \\
\hline $\begin{array}{l}\text { about } t_{h_{\text {Imax }}} \\
\text { streamline body }\end{array}$ & great & $\begin{array}{l}\text { no streamline } \\
\text { required }\end{array}$ & intermediate \\
\hline jaws & $\begin{array}{l}\text { rotatable, } \\
\text { biting }\end{array}$ & $\begin{array}{l}\text { protrusion, } \\
\text { no biting }\end{array}$ & $\begin{array}{l}\text { rotatable, } \\
\text { biting }\end{array}$ \\
\hline $\begin{array}{l}\text { branchiostegal } \\
\text { valve }\end{array}$ & not wide & intermediate & wide \\
\hline $\begin{array}{l}\text { taxonomical } \\
\text { groups }\end{array}$ & $\begin{array}{l}\text { Protacanthopt., } \\
\text { Paracanthopt., } \\
\text { Acanthopterygii }\end{array}$ & Acanthopterygii & $\begin{array}{l}\text { Paracanthopt., } \\
\text { Acanthopterygii }\end{array}$ \\
\hline
\end{tabular}

ently closed valve. When the cylinder expands during a time $\Delta t$ it fills with water. The water velocity at the valve is zero. At a small distance $\Delta x$ from the valve the water velocity is determined by the filling of the part of the cylinder (the "disk") between the valve $(x=0)$ and $x=\Delta x$. When the expansion of the cylinder has a value $\Delta A / \Delta t$, the filling of the involved disk is $(\Delta A / \Delta t) . \Delta x$. The latter quantity is thus the volume of water $(\triangle A . \Delta x)$ that fills the disk in a time interval $\Delta t$ i.e. the volume flow (flow rate). The water velocity at $x=\Delta x$ is obtained by dividing the volume flow by the area through which the water is passing i.e. $A_{t}$ (at instant $\Delta t$ ). So, the water velocity at $x=\Delta x$ and $t=\Delta t$ becomes:

$$
u_{v} \approx \frac{I}{A_{t}} \cdot \frac{\Delta A}{\Delta t} \cdot \Delta x
$$

The velocity at greater distances from the valve is obtained by summing the velocities generated by the filling of subsequent disks. For limit values of $\Delta A$ and $\Delta t$ tending to zero and integration with respect to $x$ the final formula for the water velocity is obtained (see Appendix I).

When the profile compresses the water flow is reversed. So, the sign (and thus 
FIG. 14

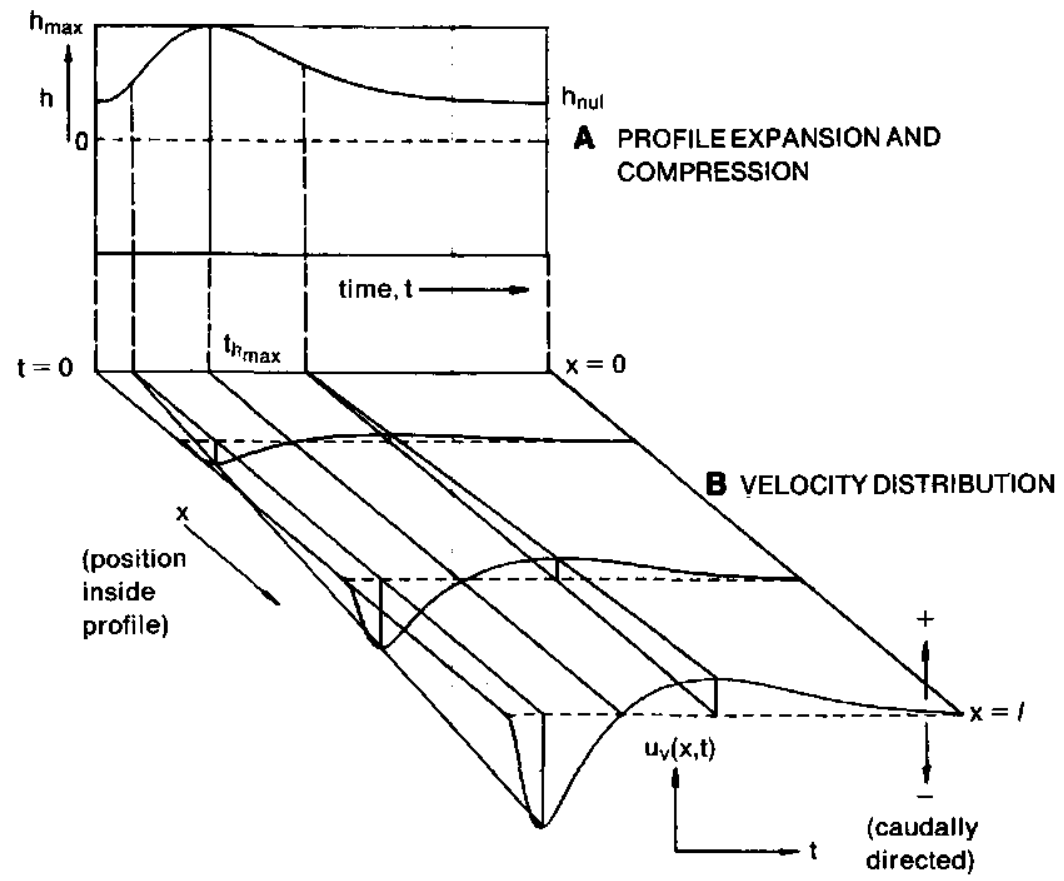

FIG. 14. The flow in a radially expanding and compressing cylinder with closed valve.

A: motion of the cylinder wall as a function of time.

B: the velocity $u_{v}$ as a fuction of position and time. A positive velocity is rostrally directed. At $t_{h_{\max }}$ the flow direction is reversed. The velocity distribution inside the cylinder is runninglinearly from $u_{v}=0$ at $x=0$ to the maximum velocity at $x=l$ ("mouth aperture"). Further explanation in text.

$h=$ profile radius, $h_{\text {nul }}=i$ idem at $t=0, h_{\text {max }}=$ maximum profile radius, $t=$ time, $x=$ position inside profile, $u_{v}=$ velocity without opening valve, $l=$ mouth length, $t_{h_{\text {max }}}=$ time of maximum excursion of the cylinder.

the direction) of the water velocity as a function of time is equal to the sign of the first derivative of the profile's movement curve and therefore the water velocity passes through zero at the time of the extreme value of the profile movement. The velocity distribution of the water inside the cylinder is running linearly from zero value at the valve to the maximum value at the mouth aperture

\section{D2.2. Cone with closed valve (Fig. 15)}

A more complex movement is obtained when a conical profile is considered. The valve is again kept closed.

Suppose the cone carries out the following movements:

First, the buccal region described by the mouth aperture radius $h_{1}$, carries out an excursion and the profile radius at the opercular valve remains constant (Fig. 15: A1-4,B3). When the mouth aperture regains its initial value the opercular 
valve $(x=0)$ to its maximum value at the mouth aperture $(x=l$; Fig. 15: B5).

In the case of the cylinder with similar and simultaneous movement of buccal and opercular walls only a single velocity peak during suction is present and the prey is sucked in one continuous movement. In the "biphasic" movement of the cone through separate actions of buccal and opercular walls the water velocity is double peaked during suction. Between those extremes a continuous range of movements is possible. In Fig. 15C and yet more in Fig. 15D buccal and opercular movements increasingly overlap in time. Evidently, single peaked velocity curves may be generated by an excursion of either the buccal or the opercular walls.

\section{D2.3. Opening of the valve}

D2.3.1. Manipulation of the flow by opening of the valve and with open valve.

When the opercular and branchiostegal valves open, the water velocity is not only determined by the filling of the profile but the volume flow through the opercular slits must also be taken into account.

From the equation of continuity (ref: Muller et al., 1982: form. 16-20) the following formula for the velocity at the mouth aperture is obtained:

$$
u_{n}(l, t)=u_{v}(l, t)+\frac{u_{n}(0, t) \cdot A(0, t)}{A(l, t)}
$$

$((t \geq \tau ;$ the formulas are numbered in Appendix I)

$u_{v}$ is water velocity without opening of the valve, $u_{n}$ is velocity with opening of the valve, $A$ is area of transverse section of the profile.

This formula shows that it is possible to increase the flow velocity into the mouth aperture by opening of the valve. To study this important phenomenon more precisely consider a prey sucking fish and suppose that he prey has not yet been caught at the moment the valve opens. The fish might try to increase the water velocity into (and so in front of) its mouth aperture. As appears from the above formula the only way to achieve this is allowing the water to stream out of the opercular slits i.e. to assign a negative value to $u_{n}(0, t)$. When $u_{n}(0, t)$ has reached a certain negative value the flow into the mouth aperture can be further increased by a continuing expansion of the opercular region i.e. enlargement of $A(0, t)$ (note that assumptions about $A(x, t)$ also influence $\left.u_{v}(x, t)\right)$.

Such an expansion however has only an advantageous effect if $u_{n}(0, t)$ maintains a negative value i.e. there is a continuous caudally directed flow out of the opercular slits. Otherwise the effect will be a decrease of the flow into the mouth aperture due to filling of the profile through the opercular slits. So, extra expansion of the opercular region may amplify the water flow into the mouth aperture but is restricted because continuing expansion of the opercular region may $u_{n}(0, t)$ cause to decrease in magnitude.

The velocity in the fish's mouth aperture is also enlarged when $A(l, t)$ decreases i.e. when the mouth aperture is diminished, this however can also result in a 
FIG. 16

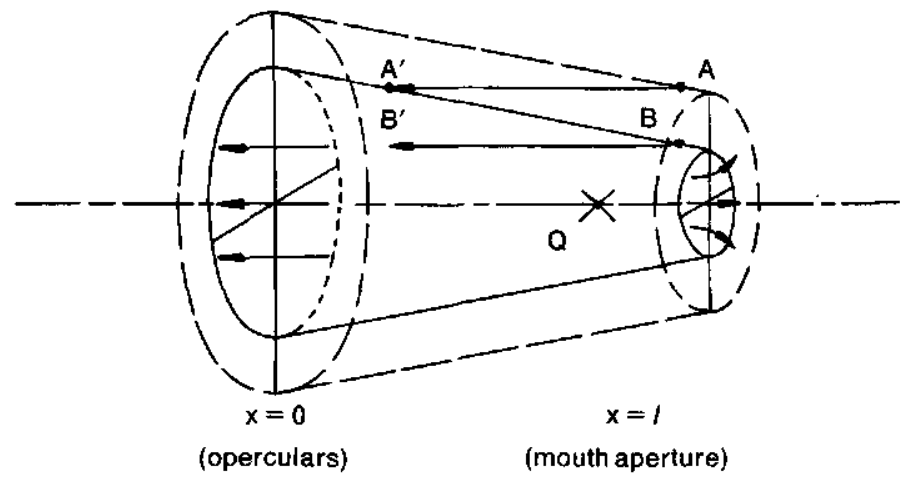

Fig. 16. Flow following from compression of a conical profile which is open at both ends.

The flow is drawn in the frame of the profile. At the point $A$ the profile radius has a value $h(A, t)$. After compression this radius is present in $A^{\prime}$. Analogously the point $B$ comes to lie at $B^{\prime}$. So water is forced by the wall in a caudal direction. Evidently, the water streams out of both openings of the profile. The caudally directed flow has a greater value than the flow to rostral. At the point $Q$ the fluid is at rest with respect to the profile. The position of $Q$ greatly depends upon previous events in the suction movements and the necessity to use unsteady flow formulae is evident. Further explanation in text (section D2.3.1).

decrease of $u_{n}(0, t)$. When the prey is not yet caught such a diminution will be unfavourable because the prey might be too large to pass the reduced mouth aperture and the conical inflow field in front of the mouth aperture narrows down allowing the prey to escape.

When the prey has already passed the mouth aperture the water velocities can be increased by fast closure of this aperture thus ensuring a caudal transport of the prey and preventing its escape. The morphological implication of this, in view of the broadened lower jaws, is a quite powerful jaw adductor muscle.

That even compression of the buccal region may contribute to a caudally directed flow is apparent from Fig. 16. When a conical profile is compressed the fluid inside is pushed to its wide end by the wall. Due to the compression of the profile fluid will flow outwards through both the apertures.

At a certain point (Fig. 16: $Q$ ) inside the compressing profile the net effect will be zero. If the buccal region compresses, possibly coupled with still an expansion of the opercular region, the point $Q$ will lie very close to or even in the mouth aperture and so a caudally directed flow is maintained or increased thus assisting in prey capture. This situation is frequently met.

( $Q$ will also be moved towards the mouth aperture due to the forward translation of the profile in an earth-bound frame; see D4.2, Fig. 23).

It appears from the experiments that the prey passes the mouth aperture when that aperture has reached its extreme value (Fig. 17). So, the behaviour of the fish exactly fits the hydrodynamical conditions discussed resulting in the suction of a minimal amount of preyless water. It will be apparent that the amount of sucked water can be several times the volume of the expanded head when 


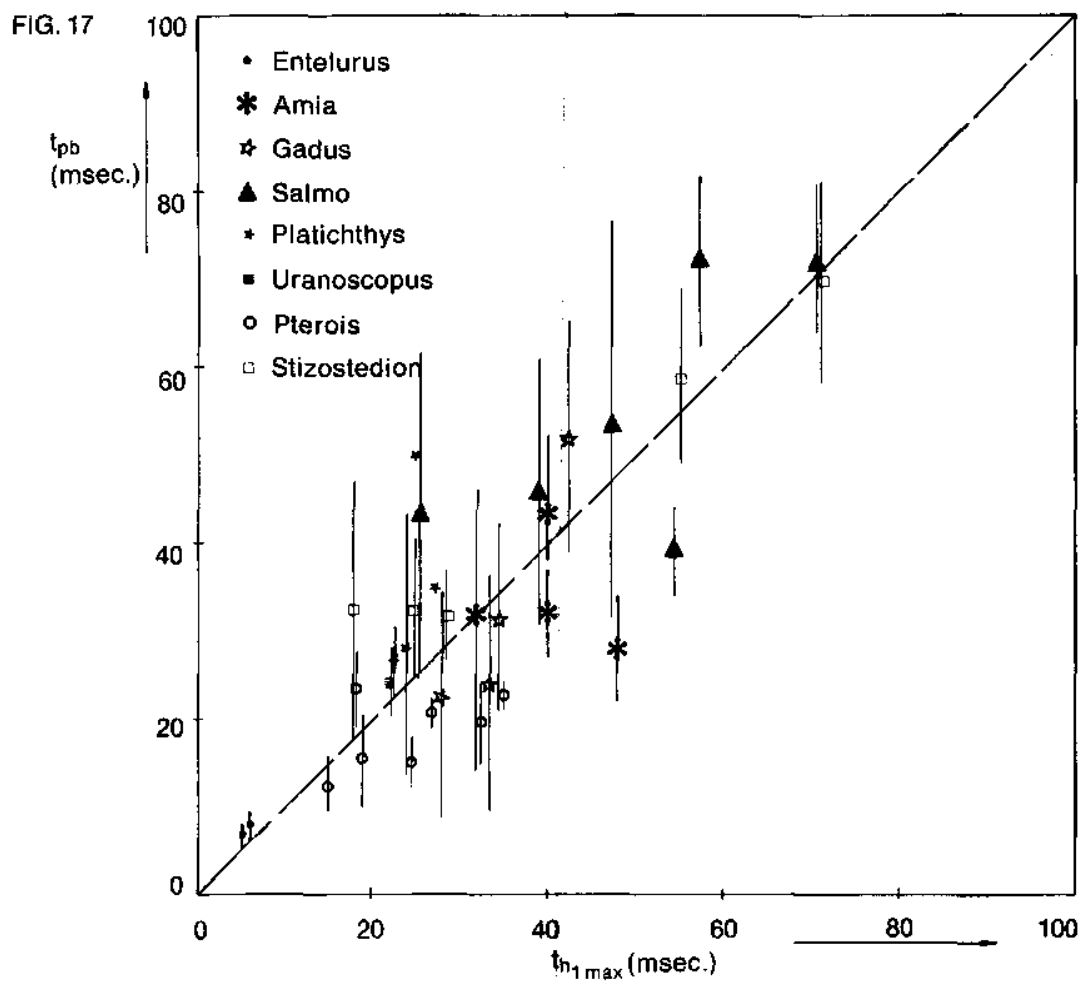

FIG. 17. Diagram showing that the prey is swallowed at the time of maximal mouth radius. The vertical lines indicate the time between entrance and disappearance of the prey. Note that in most of the depicted species the time range of prey capture is quite narrow whereas the open water feeders (Stizostedion, Salmo) have a wide range of timing their maximal mouth aperture. This is due to the also variable swimming velocity. So details of the suction act clearly mirror the ecological conditions of the species.

Data from different snaps of one individual of a species (Table I). $t_{p h}=$ time at which the prey is engulfed, $t_{h_{\max }}=$ time at which the maximum mouth aperture is reached. Times in msec.

the water is allowed to stream out of the opercular slits. This has been demonstrated by Van Leeuwen (in prep.) for the trout. Therefore it is useful to consider the conditions determining this outflow.

\section{D2.3.2. Conditions for outflow from the opercular slits.}

The velocity of the water in the mouth opening of an expanding profile with closed valve can be calculated from the volume increase, the area of the opening mouth and from the condition that at the valve no flow occurs i.e. the velocity is zero (in the frame of the profile). When the valve opens up inflow or outflow can occur, a zero velocity would be an exceptional case. To determine the velocity with opened valve the previous condition of zero flow must be replaced by 
FIG. 18

A

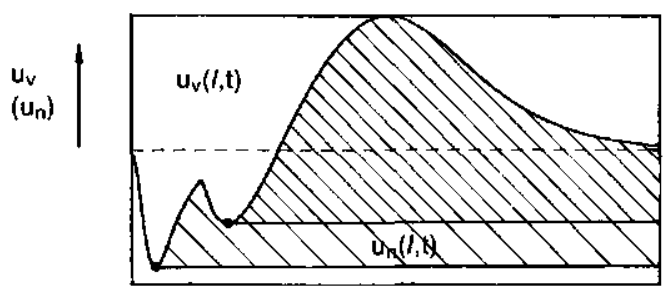

B

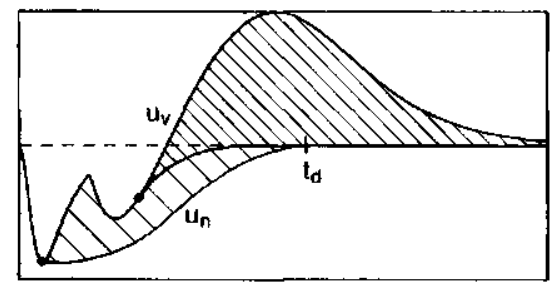

time, $\mathrm{t} \longrightarrow$

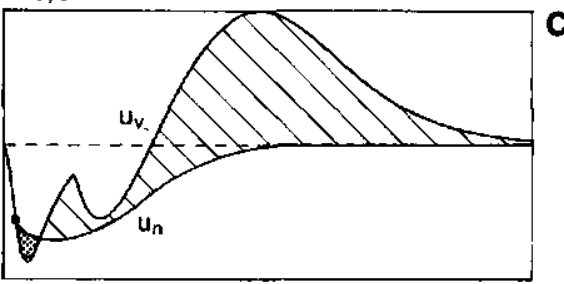

D
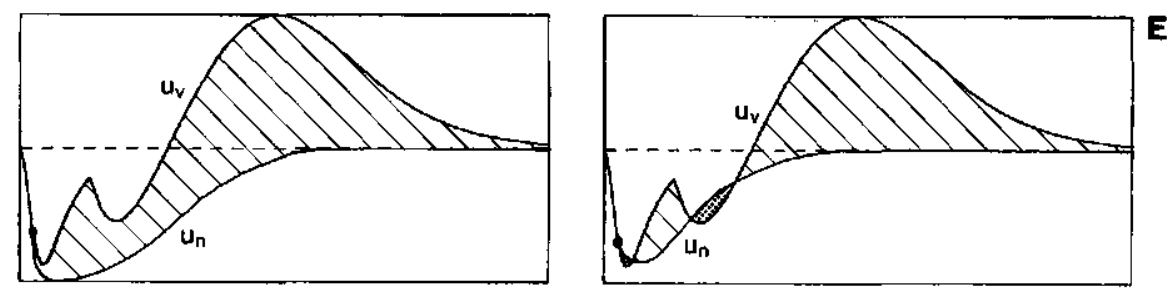

FIG. 18. The flow in the opercular slit determined from the flow at the mouth aperture. The large dots indicate possible times of opening of the valve $t=\tau$.

The cross-batched areas show the velocity of the water, which flows from the opercular slits after $t=\tau$, multiplied by the ratio of opercular and buccal expansion (see D2.3.1).

The dotted areas represent the flow entering the opercular slits. A series of options for the choice of the boundary condition is given:

A: constant boundary conditions $u_{n}(l, t)$, showing that due to the choice of a constant negative velocity in the mouth aperture after $t=\tau$ a caudally directed flow is maintained through the opercular slits (Muller et al., 1982).

B: More realistic boundary conditions involving closure of the mouth aperture (Van Leeuwen and Muller, in prep.). A caudally directed flow through the opercular slits is also achieved. However, the magnitude of this flow depends strongly on the chosen shape of the curve of $u_{n}$.

C: boundary condition crossing the velocity without opening of the valve when this valve opens very early; inflow occurs through the opercular slits.

D: avoidance of such an inflow by a negative increase of the boundary condition compared to the flow with valves closed.

$\mathrm{E}$ : inflow caused by crossing the first and/or the second velocity peak occurring during conical expansion. Further explanation in the text (section D2.3.2). $t=$ time, $u_{v}=$ water velocity without opening of the valve, $u_{n}=$ idem with opening of the valves, $l=$ mouth length. 
another condition, a boundary condition, stating at any place a velocity or a pressure.

When a velocity is chosen as a boundary condition, this velocity must have the same order of magnitude as the velocities which can be generated by the profile with valve closed. It must however within this range also significantly differ from the velocity at the concerning site with valve closed.

Muller et al. (1982) choosed the boundary condition by stating that for $t>\tau$ the water velocity in the mouth aperture $\left(u_{n}(l, t)\right)$ remains constant (Fig. 18A). The instant $t=\tau$ was then chosen to occur at an extreme value of the water velocity in the mouth aperture without opening of the valve, $u_{v}(l, t)$. This choice of the boundary condition was preliminary and intended to state the problem. A better approximation of the boundary condition is given by Van Leeuwen and Muller (in prep.). In the latter paper the closure of the mouth aperture (defined by an instant $t_{d}$ ) has been taken into account and also more flexibility was achieved to choose the instant $t=\tau$ (Fig. 18B).

A quantitative determination of the boundary conditions is not yet possible for the general case. Therefore, a qualitative approach is preferred by trying to derive graphically some conditions for outflow from the opercular slits. Consider therefore the equation (8) in another form:

$$
u_{n}(0, t)=\left[u_{n}(l, t)-u_{v}(l, t)\right] \cdot \frac{A(l, t)}{A(0, t)}
$$

This formula shows that the direction of the flow in the opercular slits is determined by the difference of the water velocity in the mouth aperture which occurs with opening of the valve $\left(u_{n}(l, t)\right)$ and the velocity which would occur if the valves would be kept closed $\left(u_{v}(l, t)\right)$.

Hence a flow through the opercular slits into the opercular cavities only occurs if $u_{n}(l, t)>u_{v}(l, t)$ as indicated in Fig. $18 \mathrm{C}$. As this reduces the suction velocity into the mouth aperture (see D2.3.1) it is advantageous for the predator to avoid this situation as shown in Fig. 18D.

In the case of the cylinder this can only be achieved by choosing a proper moment to open the valve, $t=\tau$. More flexibility is reached for a conical profile because manipulation of the flow after $t=\tau$ as described in D2.3.1 is possible. For motions which result in double peaked velocities (cf. Fig. 15) with valve closed $\left(u_{v}\right)$ there is however a chance that the velocity curve $u_{n}$ intersects the curve $u_{v}$ during the second peak.

Furthermore when the valve opens before the first peak of $u_{v}$ also intersection of $u_{v}$ and $u_{n}$ may occur resulting in a flow into the opercular slits during a short time (Fig. 18E). The latter is probably the flow mentioned by Lauder (1980b: p. 67). The occurrence of this flow must either be interpreted as a failure of the predator to generate the most effective suction movement or as a compromise by allowing a brief caudal inflow at an early time in order to generate a greater velocity into the mouth aperture during a later period. The results of Van Leeuwen (in prep.) prove that for Salmo gairdneri the latter possibility is applicable. 

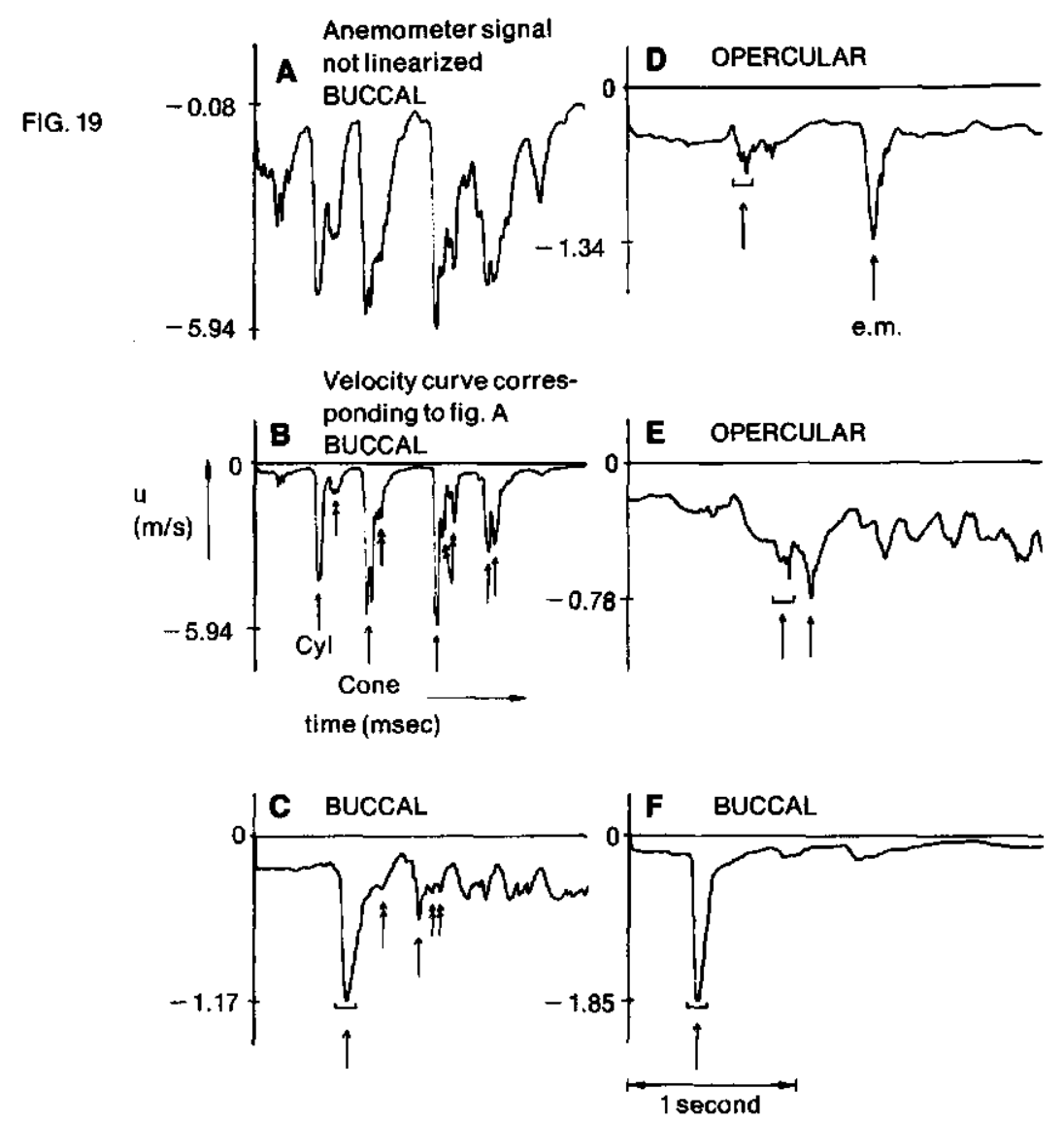

Fig. 19. Water velocity measurements in sucking trout (Salmo gairdneri; head length: $70 \mathrm{~mm}$ ).

The hot film anemometer probe was mounted inside the buccal cavity (at about $0.7 l$ ) or just behind the opercular slit (dorsocaudally). The signal was stored on tape (bandwidth $5 \mathrm{kHz}$ ) and sampled with an AD-converter at $2 \mathrm{kHz}$. The unlinearized curves (as an example: see A) were linearized with the aid of a measured and interpolated calibration curve. Care was taken for a proper level of this curve relative to the signal. After linearization the example shown in A becomes a velocity curve B. The presented curves posses a resolution of about $100 \mathrm{~Hz}$. This does not give rise to loss of information compared to the original curves. Velocities are in $\mathrm{m} / \mathrm{sec}$. The negative direction is to caudal.

The graphs present different snaps of the same animal. The single arrows indicate snaps of the fish, the double arrows designate handling movements. Example B is the most fast and extreme one. The animal carries out several subsequent snaps. These snaps go together with considerable swimming. The snap marked "Cyl" is like a cylindrical profile, "Cone" is like a conical one. Example C and F are relatively slow and weak suction movements. The snap marked e.m. in example $D$ is probably a cleaning movement and went together with an extreme dart of the fish.

Because the velocity starts to a negative direction and does not reach again a zero value, it can be concluded that no positive velocities are generated. When a zero value would be reached, it would be impossible to separate positive and negative velocities due to the unidirectional sensitivity of the probe. Because the probe is very sensitive for low velocities a zero passing would be easily determined. The velocity is always caudally directed. The negative starting level is probably caused by intensive respiration. Buccal and opercular velocities are of the same order of magnitude. 


\section{D2.4. Velocity measurements (Fig. 19)}

Measurements of the water velocity in and about the fish's mouth were carried out to check the velocities calculated using the model with the velocities actually occurring during prey suction.

In order to get a first impression about the magnitude of the water velocities occurring in front of the fish's mouth and caudally of the opercular slits, silverplated polystyrene spheres were added to the water with the prey (see B3) and the velocities were measured from the film. In Pterois the peak velocity at the mouth aperture is about $0.5-2.0 \mathrm{~m} / \mathrm{sec}$ and the maximal velocity at the opercular slit $0.1-0.5 \mathrm{~m} / \mathrm{sec}$. Apparently these measurements suffer from inaccuracy due to the required differentiation procedure. Furthermore, peak velocities are not detected because they easily fall within the $2.5 \mathrm{msec}$. interval between the movie frames and so are averaged over this interval with much lower velocities. Van Leeuwen (in prep.) optimized the method by applying stereoscopical techniques.

A complicated other technique is to measure the water velocities by inserting a hot film anemometer probe in the flow (see B3). Complications are due to calibrating procedures, contamination of the probe, unidirectionality of the probe and the adverse influence of the probe on the fish. The advantages of this method are: 1) an accurate measurement of a velocity curve as a function of time at a distinct position is obtained and 2) the flow can be measured also inside the fish's mouth. Fig. 19 provides some examples of velocity measurements inside the fish's mouth during suction acts of Salmo. The graphs present different snaps of the same animal. In Fig. 19B some successive fast feeding acts are recorded. Note that velocities reach values of up to $6 \mathrm{~m} / \mathrm{sec}$ for very short times. Typical peak-velocities are less than 1-2 m/sec.*

Similar velocities are recorded from the opercular area when the opercular slits are open. Note the differences in steepness of the velocity curves of Fig. 19B and $\mathrm{C}$.

The velocities always maintain a negative value. After feeding a value of about $10-30 \mathrm{~cm} / \mathrm{sec}$ is reached again. This value is reported as an average speed of the water during respiration (Holeton and Jones, 1975). The cylinder model fits best the trout's movements (Fig. 19B: Cyl) and during these movements the prey is captured. During food handling i.e. transport inside the buccal cavity movements are better described with a cone model (Fig. 19B: Cone).

As the recorded velocities and also the pressures (Van Leeuwen and Muller, in prep.) agree with model predictions these data prove that the model approach gives a quite satisfactory description of the feeding events (see D1.1).

\section{D2.5. Some morphological features as determinants of the flow (Fig. 20)}

\section{D2.5.1. Sealing of the opercular slits}

In Fig. 20A the water velocity distribution inside the mouth with valve closed

* In Fig. 2 (Osse and Muller, 1980) the depicted buccal velocity is three times less than indicated, due to wrong positioning of the calibration curve of the probe. Opercular values are correct. 
FIG. 20

A
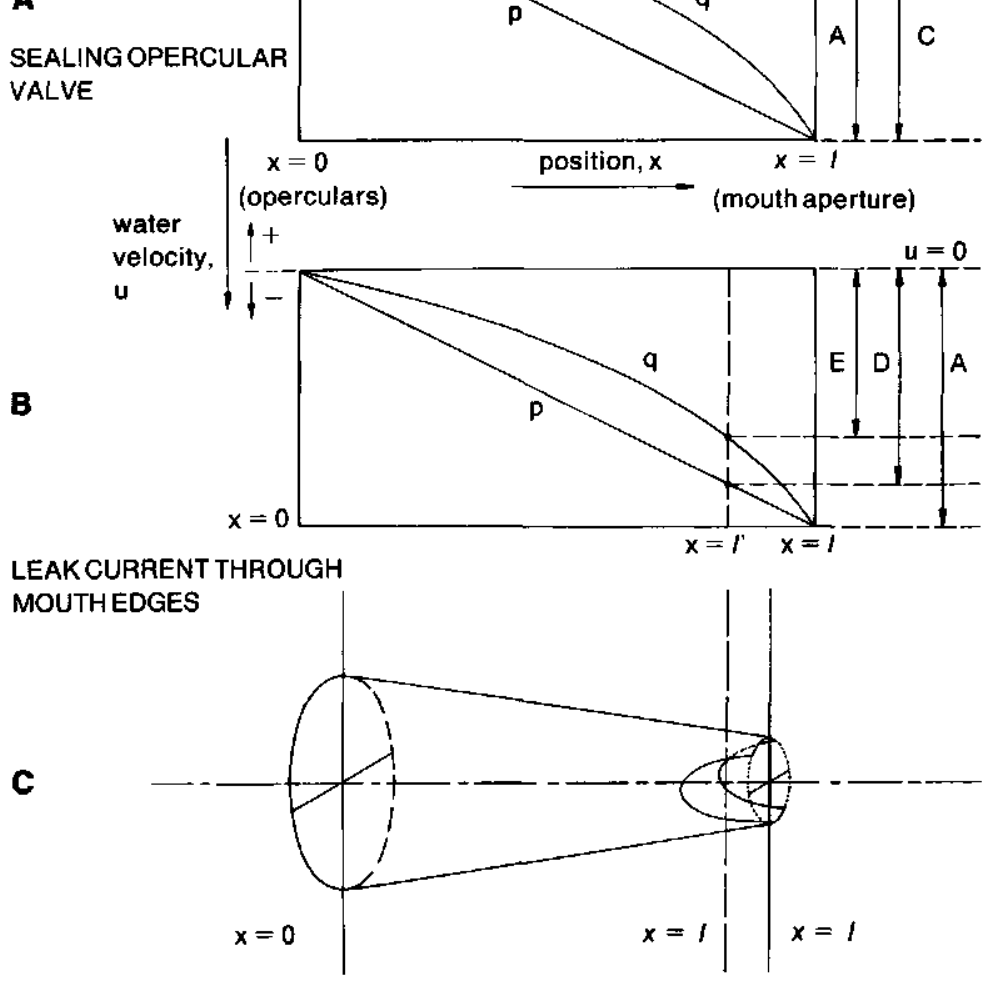

FIG. 20. Effects of leak currents through the mouth edges and the opercular slits on the water velocity into the mouth aperture. This figure is explained in the text (section D2.5).

is given both for a cylindrical (curve $p$ ) and a conical profile (curve $q$ ). It is supposed that the suction capacity of both profiles is the same and therefore the water velocity at the mouth aperture has a magnitude $u_{v}(l, t)=C$. Now, consider the case wherein a leak current of magnitude $u(0, t)=B$ through the opercular slits occurs. Then, the velocity curves can be translated vertically over a distance $B$ and the new axis of zero water velocity becomes $u^{\prime}=0$. The water velocity at the mouth aperture $(x=l)$ is thus reduced to a magnitude $A=C-B$ and the points of zero water velocity become respectively $P$ for the cylinder and $Q$ for the cone. So the effect of the suction is reduced. In this simplified scheme e.g. the variation of the gill resistance is not taken into account (see C3.5, D3.2). From the above it is apparent that an effective sealing of the opercular slits is a prerequisite for the functioning of a feeding mechanism by suction, especially with cone form. Besides, a complete sealing protects the delicate gills against 
a fast rostrally directed flow, fast as compared to the flow generated during respiration.

It is therefore not surprising that the gill cover developed very early in fish evolution from a system of valves attached to each individual arch (as in Climatiidae $\dagger$ : see Miles, 1971) to a single gill cover (as in Acanthodidae $\dagger$ ). Miles (1971) also argued that the feeding habits of acanthodians did, in the course of the evolution, change from a primitive type of filtering to a predatory behaviour, going together with an increase in swimming capacity (elongation of the body, development of body musculature). These deductions agree with our hydrodynamical considerations. A transition from filter feeding to low- $\tau$-feeding with swimming must go together with a much better sealing of the opercular slits in the beginning of the suction movement.

An increase in the efficiency of the suction mechanism requires a further perfectioning of the sealing capacity of the branchiostegal valves. So it is required that the valve closely follows the body curvature from lateral to ventral. The development of a dermal pectoral girdle in palaeoniscoids provides the surface to let the valve slide along during abduction. As, beside abduction of suspensoria and opercula, hyoid movements also largely contribute to the expansion, the valve must at the ventral side be quite flexible. Therefore the branchiostegals and operculars as a series of plates decrease in width from lateral to ventral in these fishes.

The change from low- $\tau$-feeding with swimming to high- $\tau$-feeding (volume suction) in teleosts is accomplished by the development of aciniform rotatable branchiostegal rays (see also Osse, 1976). In this case an enormous caudal expansion with a sealed valve and thus without caudal inflow is possible and so a great impulse can be given to the water containing the prey. The functional significance of the peculiar rostral extension at the ventral side of the branchiostegal slit is given by Van Leeuwen (in prep.).

\section{D2.5.2. Closure of the edges of the mouth aperture; protrusion}

Fig. 20B gives once again the water velocity distribution inside the mouth with closed valve for both a cylindrical and a conical profile with the same suction capacity (i.e. $u_{v}(l, t)=A$ ). Now, suppose that the mouth aperture of the profile is not formed by a circle at $x=l$ but that it possesses an irregular shape (Fig. 20C). Then "leak currents" do occur through these angles of the mouth aperture and the water velocity at $x=l$ would be similar to the velocity generated by a profile with a smaller length $l^{\prime}$. Or, reversing the argument: if one compares the water velocities at the mouth aperture of two profiles possessing respectively a length $l$ and a length $l^{\prime}$, a considerable reduction of the velocity at the mouth aperture to the value $D$ (cylinder) and $E$ (cone) in the latter profile is reached (Fig. 20B). The above reasoning demonstrates the hydrodynamical importance of closure of the mouth angles. The development of movable rotatable maxillaries with accompanying membranes in the holostean level (cf. Schaeffer and Rosen, 1961) is therefore an important structural adaptation to the suction feeding function. At present we are experimentally testing this statement by removing 
the maxillaries of a trout and measuring the effect on the water velocities, so attempting to reconstruct a palaeoniscoid type.

The above conclusions all apply to situations where a protrusion mechanism of the mouth aperture is present. This feature of e.g. the Acanthopterygii provides an enormous gain of the water velocity in and in front of the mouth aperture (in the fish's frame), especially when the mouth tapers to rostral. Besides, protrusion increases the directiveness of this suction flow and reduces the impulse given to the water (cf. D1.3.2 and D3.3.4).

\section{D3. VELOCITIES; THE SHAPE OF THE FLOW.}

\section{D3.1. Results of flow visualization}

Flow visualisation was applied for the following reasons:

1) To localize singularities in the flow in order to obtain a starting point for model construction (ref. C3.6).

2) To estimate the average water velocities occurring during a suction act at the mouth aperture and the opercular slits. This provides a check for the validity of the model approach for the internal flow (ref. D2).

3) To check the validity of the simplified model approximations for the external flow (ref. D3.3).

4) To obtain a boundary condition for the flow with open valve (ref. D2.3, D3.4, D4.4.2).

The visualization of unsteady flow demands that 1) the flow is consistently considered in the same frame of coordinates and 2) a distinction is made between streamlines and path lines (see also C2).

Although it may seem obvious that the flow must be considered relative to a definite frame of coordinates, in practice a confusion of frames occurs surprisingly rapidly (and without being perceived). This is illustrated by the following example. Suppose one is observing a ciné-film of a sucking fish. The fish sucks itself forward and, at the same time, the prey is moving into the mouth aperture (in the earth-bound frame). The flow in front of the mouth aperture will now appear to be bound by a "cone" whereas beside the fish there seems to be no flow of any importance. In this case of optical illusion the flow in front of the mouth aperture is considered relative to the fish. The flow next to the fish is however referred to the earth-bound frame. It is apparent that such a double interpretation of the flow may lead to errors. The consequent application of the flow with respect to the moving frame, having its origin in the mouth aperture, is apparent from Plate 4D,E,F and G (see D3.3.4).

When e.g. in the earth-bound frame a rapid lifting of the head of a pipefish occurs this is depicted in the moving frame as a reverse rotation of the body with respect to the axis of the head. An analogous reasoning must be applied when protrusion occurs; in the moving frame the body moves backwards.

In D3.3 (Fig. 21) it will be shown how the flow changes as a function of the time for different suction acts. 

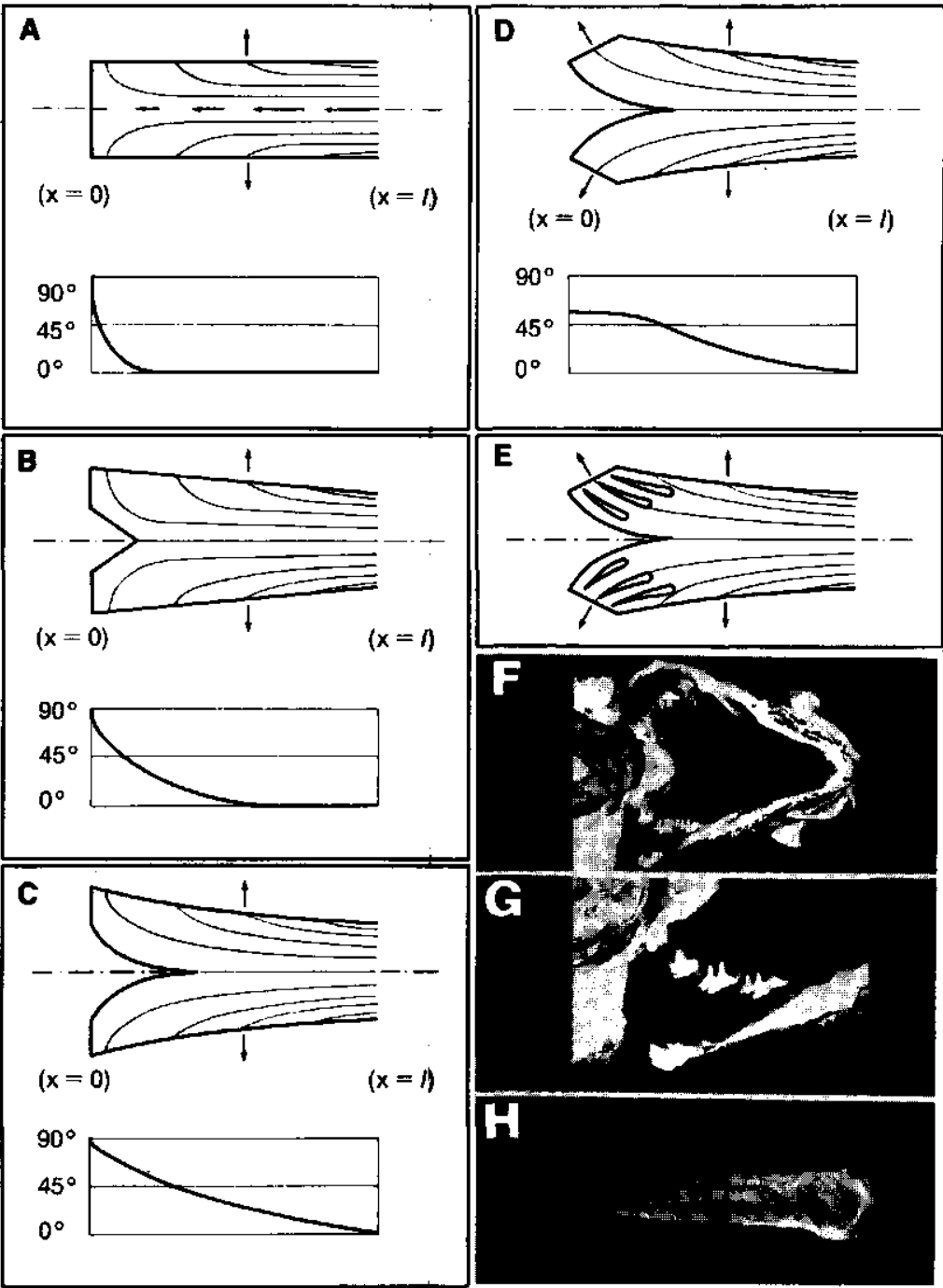

Plate 3. Streamline patterns inside and relative to different expanding profiles with graphs of the angles between streamlines and profile axis at the level $0.5 \mathrm{~h}$.

A profile form, resembling the fish's mouth shape, results when the variation of the local accelerations is minimized i.e. the angles between streamlines and axis. $x=0$ : opercular valves, $x=l$ : mouth aperture.

A: cylinder; abrupt variation of the angles occurs.

B: cone; a gradual increase in the curvature of the streamlines is obtained. A wedge (pectoral girdle, sternohyoideus) can be inserted in the low velocity region.

$\mathrm{C}$ : cone with progressive increasing radius to caudal; further smoothing of the curvatures of the streamlines. The pectoral wedge reaches further forward.

D: Expansion of the opercular valves has the effect that the angles do not reach 90 degrees. 
When the snout becomes very long (syngnathids) the angles tend to zero.

E: position of the gills along the streamlines. Note the increased angle of the caudal gill filaments with the body axis and the wedge form of the pectoral girdle.

F: actual profile form of a frozen section of Pterois (headlength $50 \mathrm{~mm}$ ) for comparison.

G: detail of the gill region.

$\mathrm{H}$ : hydrofoil shape of a gill arch of Salmo (length $7 \mathrm{~mm}$ ). Refer also Plate 1, Fig. 2 and

Fig. 6. Further explanation in text (section D3.2).

\section{D3.2. The flow inside the profile (Plate 3)}

To calculate the water velocity inside the mouth cavity the flow can be approximated by a parallel stream (see C3.5).

Here we will argue that the shape of the fish's mouth at every position causes a minimum of pressure drag. Consider therefore first the real flow inside and relative to an expanding cylinder with valve closed (Plate $3 \mathrm{~A}$ ).

In the $x$-direction the water velocity along the axis, $u_{v}(x, t)$, increases linearly from zero at $x=0$ to the maximum value at $x=l$ (see D2.1). The water velocity in the $r$-direction at the profile wall, $v_{v}(x, h, t)$, is constant as a function of $x$. In the remaining part of the field the actual water velocity $q$ has a direction determined by the relative magnitudes of $u_{v}(x, r, t)$ and $v_{v}(x, r, t)$ there, satisfying the relation $q^{2}=u^{2}+v^{2}$. This implies that the flow direction changes gradually from parallel to the profile wall anteriorly to more oblique to that wall at the opercular end of the profile. Thus the influence of the profile expansion on the flow direction is greater in the caudal parts of the profile than in the rostral parts.

Every change of the direction of a streamline requires an acceleration of the water. It is favourable to minimize the variation of the local accelerations i.e. the angles between streamlines and profile axis. This can be achieved by giving the profile a conical shape and by inserting a conical wedge inside the opercular cavity, actually formed by the pectoral girdle (Plate 3B).

A next step is to increase the radius of these cones non-linearly in a caudal direction (Plate $3 \mathrm{C}$ ) and to involve the motion of the valve in the suction movement (Plate 3D). In fish terms this non-linearity is realized by hinging the opercular from the already abducting suspensorium.

By optimizing the inner streamlining of a sucking profile in this way the actual form of a fish's mouth is closely approximated (Plate 3E, F). The technical analogue is the construction of e.g. a Borda's mouth piece from the flow through an aperture (Milne-Thomson, 1968: p. 312).

A body with minimum resistance to a flow is line- or plate-formed and oriented along the streamlines. Therefore the gills have to be situated along the streamlines during suction (Plate $3 \mathrm{E}$ ). The resistance of such a plate-formed body is however highly dependent on the flow direction. A minimization of this directional sensitivity results in the hydrofoil design. The fish's gills possess such a hydrofoil shape when they are folded together. So, they provide a minimum pressure drag at a site where the direction of the flow is changing continuously (in a caudal direction) during the suction (Plate $3 \mathrm{H}$ ). The direction of the filaments attached to one gill arch from dorsal to caudal changes in such a way that they are through the whole range parallel to the streamlines (Plate 1A, 1B, Plate 2G). 
FIG. 21

A

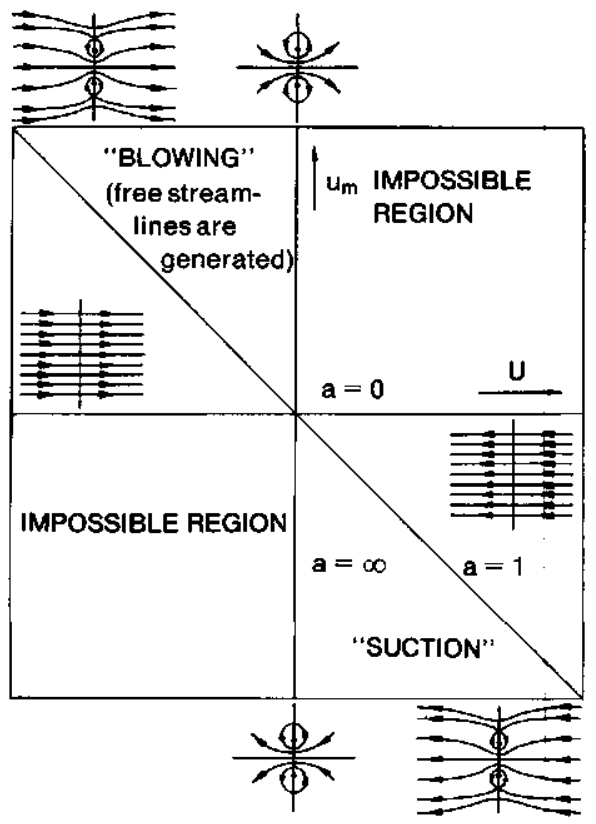

E

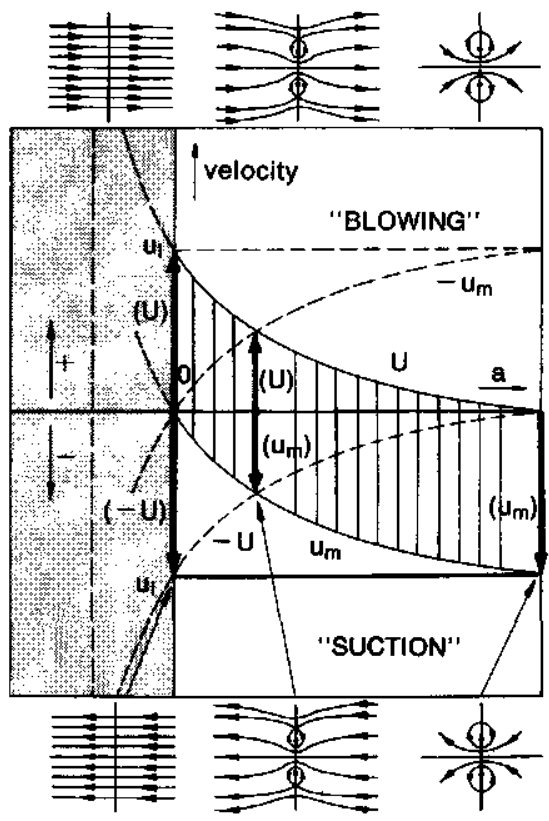

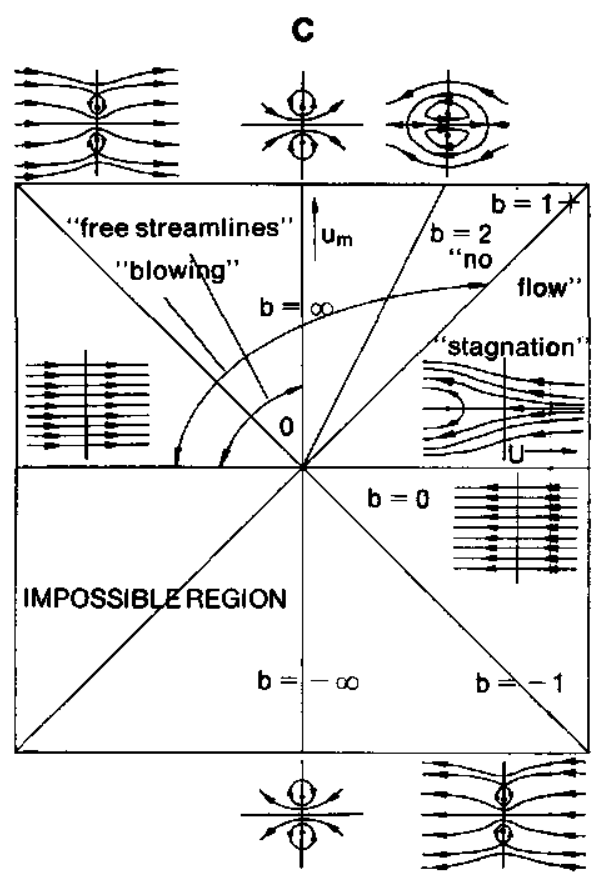

"BLOWING" D "SUCTION"

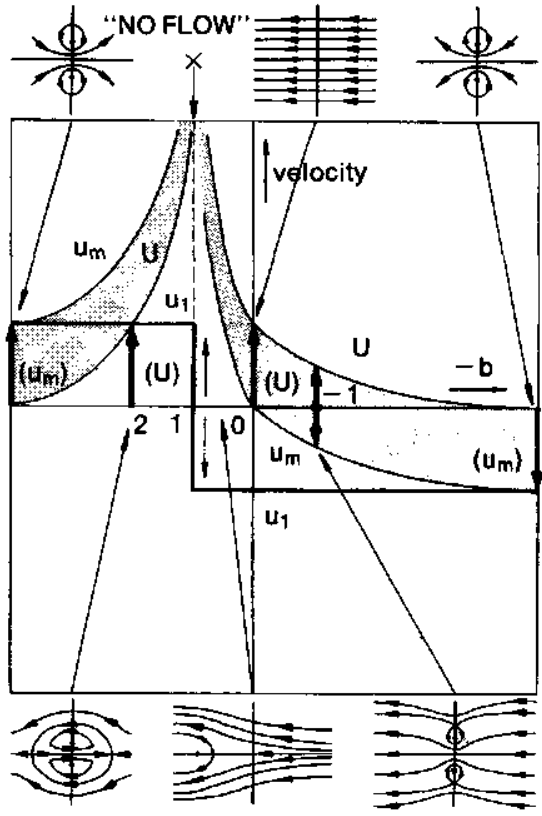




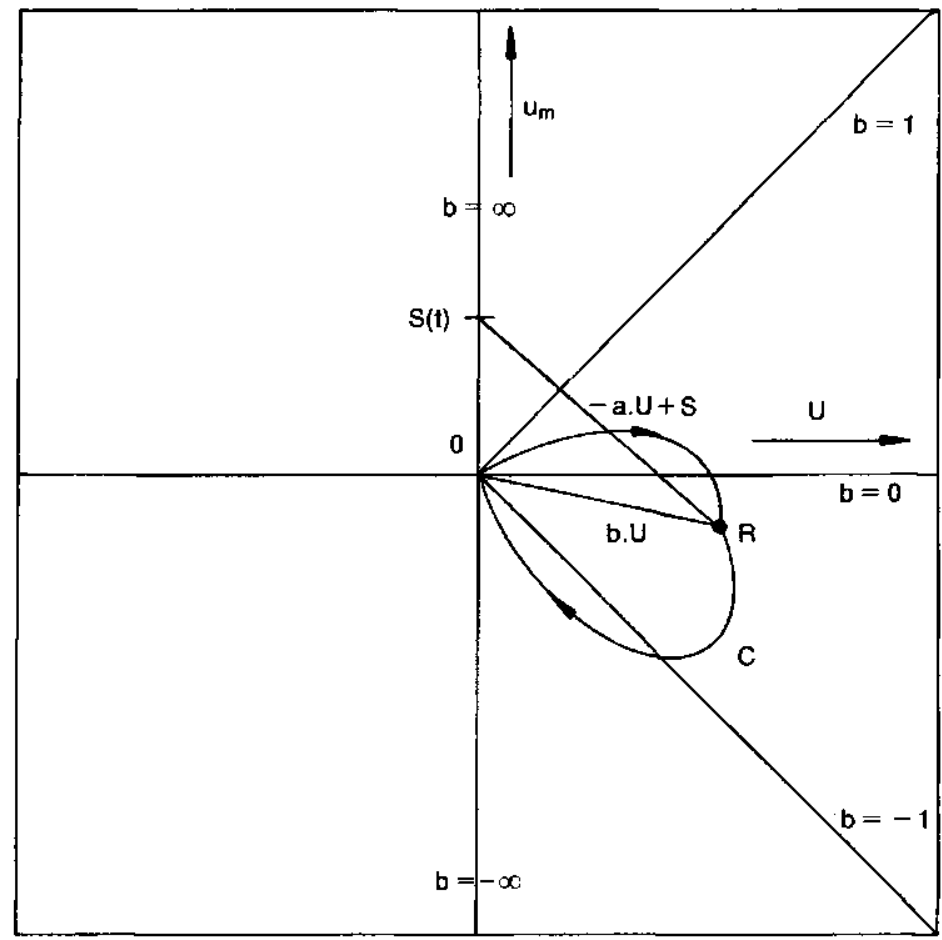

FIG. 21. Relative magnitudes of the water velocity in the mouth aperture $\left(u_{m}\right)$ and the velocity of the fish $(U)$ both in an earth-bound frame. The pictures of the flow are presented in the frame of the fish. The vertical lines in the flow diagrams indicate the plane of the fish's mouth aperture.

A: In this diagram the velocities in an earth-bound frame due to only suction are considered.

By suction the fish adds not only momentum to the water but also to its own body i.e. it sucks itself forward in an earth-bound frame. The relation between the velocity of the water in the mouth aperture $\left(u_{m}\right)$ and the velocity of the fish $(U)$ is described by $u_{m}=-a . U(a \geq 0)$. When $a$ is small, $u$ is small i.e the fish sucks itself over the hardly moving water. So, the flow relative to the mouth aperture is a parallel stream. Analogously, for large $a, U$ is small and the flow relative to the mouth aperture is undirected and can be represented by a vortex flow. For $a=1, u_{m}$ and $U$ are equal and a combination of a vortex and a parallel stream occurs.

When the directions of the velocity are reversed "blowing" occurs. Then, the flow relative to the mouth aperture is a jet bound by free streamlines. In the diagram potential-flow pictures are drawn to show the symmetry of suction and "blowing".

B: The components of the flow relative to the moving fish when only suction is considered.

The water velocity in the mouth aperture relative to the frame of the fish $u_{1}$ is obtained by subtracting the velocity of the fish $(U)$ from the water velocity in the mouth aperture $u_{m}$, so $u_{1}=u_{m}-U$. Taking a value for $u_{1}$, the fractions of $u_{m}$ and $U$ contributing to this value can be drawn for different values of $a$ i.e. for $a \rightarrow 0, u_{1}$ is approximated by the value $-U$ and for $a \rightarrow \infty, u_{1}$ is about $u_{m}$. Thus, the distance between the lines $u_{m}$ and $U$ is equal to the value of $u_{1}$. 
The broken lines indicate the relative magnitudes of the concerning velocities in the case of "blowing".

C: Analogous to diagram A but including swimming.

When both suction and swimming are taken into account the relation between $u_{m}$ and $U$ can be defined by $u_{m}=b . U$ (see section D3.3). In this relation the minus sign is omitted because $b$ may have any value.

The flow patterns obtained in the second and fourth quadrant of the picture are analogous to diagram A but yet swimming movements contribute to $U$. In the first quadrant where both $u_{m}$ and $U$ are positive the situation is more complicated. So e.g. for $0<b<1$ the value of $u_{m}$ is smaller than the value of $U$ viz. although stagnation of the prey occurs it will be engulfed at a certain instant. In the latter case the flow has a contracted shape in a positive direction.

For $b=1, u_{m}=U$; so the fish cannot catch the prey at all. For $b>1, u_{m}$ is greater than $U$; so the fish would blow out an extra amount of water.

$\mathrm{D}$ : This diagram is analogous to $\mathrm{B}$ but including swimming and thus gives the fractions of $u_{m}$ and $U$ contributing to $u_{1}$. Note the reversed $b$-axis.

For negative $b$ the relation between $u_{1}, u_{m}$ and $U$ is the same as in picture $\mathrm{B}$. The only difference is that $U$ contains also a component of swimming.

The shaded region shows again the value of $u_{1}$ between the lines of $u_{m}$ and $U$. These lines are in fact hyperboles which can be extrapolated to positive values of $b$.

For $b=1, u_{m}=U$ and $u_{1}=0$, so the lines of $u_{m}$ and $U$ are forced to run to the line $b=I$ asymptotically.

For values of $b<l$ the fish ingests water, so $u_{1}$ is negative. When $b>1$ the fish blows water and thus $u_{1}$ is positive and also the lines $u_{m}$ and $U$ have changed their position. When $b$ would have very high positive values $U$ would tend to zero and the fish would blow water with a velocity $u_{m}$ both in an earth-bound and a fish-bound frame.

E: With only suction the relation between $u_{m}$ and $U$ could be defined as $u_{m}=-a . U$. When also swimming occurs this relation can be extended to $u_{m}=-a . U+S=b . U$. The lines $-a . U+S$ and $b . U$ intersect at a point $R$. During the suction process this point describes a contour $C$ in the $\left(u_{m}, U\right)$-plane. From this contour the flow relative to the mouth aperture can immediately be determined as a function of time.

In the case when the fish protrudes its jaws, $U$ should preferentially represent the velocity of the mouth aperture (see also Fig. 22).

Further explanation in the text (section D3.3).

If however the flow reversed the situation would become quite unfavourable: the resistance of the gills will vary over a wide range and an unstable flow would result (see C3.5 and D1.3.1). The deformation of the distal parts of the filaments by the flow is seen in Plate $2: \mathrm{Gl}$.

It is probable that during the cough use is made of this effect to clean the gills (Osse, 1969). Muller et al. (1982: Fig. 9B) showed that during an actual suction movement of Pterois the gills are folded up, also when the valve is still closed.

When the flow direction is constant a hydrofoil shape is not necessary and a pointed form is permitted. This is the case for the wedge formed by the pectoral girdle because here a symmetrical flow is always present (Plate 3: E,F,G). In the region of this wedge hardly a flow would occur. So, the insertion of the sternohyoid muscle at this site does not seriously affect the flow. Its conical shape with long tendons to the hyoid can thus be considered as an adaptation to an unhampered suction flow. 
D3.3. The flow in front of the mouth aperture

In this section attention for the coordinate system used to define the velocity, either the earth-bound or the fish-bound frame, is essential.

\section{D3.3.1 The flow caused exclusively by suction}

In the earth-bound frame the mouth aperture of a sucking fish is approximated by a forward moving circular vortex filament. The velocity in the centre of the vortex is $u_{m}$, the velocity of the vortex $U$. Consider the case wherein the forward motion of the vortex is exclusively caused by the suction. Then, $u_{m}=-a . U(a \geq 0 ; a$ is a fuction of the time). When $a$ is large, $U$ approximates zero, so the vortex is hardly moving forward. When $a$ equals zero, $u_{m}$ is zero, thus the vortex sucks itself over the non-moving water.

Relative to the frame of the moving vortex the flow is approximated by a parallel stream with strength $-U$ for $a=0$, and a vortex with strength $-2 u_{m} h_{1}$ for $a$ tends to infinity (Muller et al., 1982). These considerations are depicted as a graph in Fig. 21A.*

In this scheme also the hypothetical case is drawn wherein the directions of $u_{m}$ and $U$ are reversed. Then, the vortex is blowing itself backwards (in the earth bound frame). In fact the fish will then generate a jet bound by free streamlines. This is a situation demonstrated by McCutchen (1977) where a fish is braking.

The fish generates a flow in and relative to its mouth aperture with velocity $u_{1}=u(l, t)$. Taking this velocity as a base for the relative magnitudes of the flow velocities in the earth-bound frame one gets the relation $u_{1}=u_{m}-U$. Fig. 21B shows the relative magnitudes of these velocities related to $u_{1}$ as a function of the parameter $a$ together with the corresponding pictures of the flow in the frame moving with the fish's mouth aperture.

\section{D3.3.2. The flow with suction and swimming}

The situation becomes more complex when forward swimming of the predator is taken into account. The separation of the effects of swimming and suction on the flow is virtually impossible. The analysis of the film frames provides only the relation between $u_{m}$ and $U$ including both suction and swimming by measuring the velocity of the predator $(U)$ and the velocity of the prey or the polystyrene spheres.

The latter relation can be expressed as: $u_{m}=-a \cdot U+S=b . U(a \geq 0, S \geq 0),(S$ is the swimming velocity). For $S=0$ one gets $b=-a$ : the original case wherein only suction played a role. Now, in the $\left(u_{m}, U\right)$-plane the following cases can be distinguished (Fig. 21C) $(U \geq 0)$ :

$b<0$ : The region analogous to Fig. $21 \mathrm{~A}$ : suction forward, but including the effect of swimming.

$b=0$ : In the earth-bound frame suction and swimming compensate each other thus water and prey stand still. This is e.g. approximately the case of a trout

* This schematic representation has no physical meaning for $a \rightarrow 0$, because $u_{J}$ depends on $a$ when $a$ is small. 
as measured Van Leeuwen (in prep.). Another example is a filter feeder which swims over its prey with permanently open opercular valves and which does not suck at all (e.g. Engraulis: O'Connell, 1972).

In the frame of the fish's mouth aperture a parallel stream with strength $-U$ is observed.

$0<b<1$ : In the earth-bound frame the fish pushes forward a volume of water. The velocity of the fish is however greater than the pushing velocity. So, the prey will be swallowed when the suction act lasts sufficiently long. However the more $b$ increases towards a value 1 , the more the moment of prey capture will be delayed. As the velocity in the frame of the fish's mouth aperture is largest at infinity, the streamline, separating the flow into the mouth from the flow along the fish, contracts in a positive direction i.e. when the distance to the fish's mouth aperture increases. The contraction is slight when $b$ approximates zero and strong and closer to the mouth aperture when $b$ approaches a value of $l$.

The flow drawn in Fig. 21 in the case of stagnation is simplified to a picture of a source and a parallel stream. In fact, the vortex at the fish's lips does not disappear and the flow is built up of this vortex (suction), a parallel stream (swimming) and a source (pushing by the valves).

$b=1$ : The water stands still relative to the moving mouth aperture. This is the case of a fish which does not suck but only swims forward with closed opercular valves. It will never be able to catch the prey!

$b>1$ : In the frame of the fish's mouth aperture the stagnation point comes to lie in front of the mouth aperture. For $b$ tends to infinity the stagnation point tends to an infinite position and the flow picture becomes a pure vortex. Because this vortex blows water free streamlines will be generated.

Reversion of the picture for values of $U<0$ is possible and partly indicated in Fig. 21C.

The relation between $u_{1}, u_{m}$, and $U$ as a function of the parameter $b$ for feeding by suction plus swimming is given in Fig. 21D (compare this figure with Fig. 21B).

The relation between $a$ and $b$ i.e. a survey of the relative contributions of suction and swimming is schematized in Fig. $21 \mathrm{E}$. In the $\left(u_{m}, U\right)$-plane the lines $u_{m}=-a . U+S$ and $u_{m}=b . U$ intersect at a certain point $R$ (note that $b$ must be smaller than $-a$ at each instant). During the time of the suction process this point $R$ describes a contour ( $C$ in Fig. 21E). This graph provides direct information about:

1) The balance between suction and swimming,

2) The type of suction applied (see D3.3.4),

3) The division of the impulse between water and fish,

4) How the prey is captured (overtaking, pure suction or both),

5) The shape of the flow as a fuction of the time.

Note that the real flow is in fact an unsteady flow. Therefore the above considerations are simplified and in fact they describe the flow as a series of steady situations. At this moment a flow description based on varying values of $a$ and $b$ 


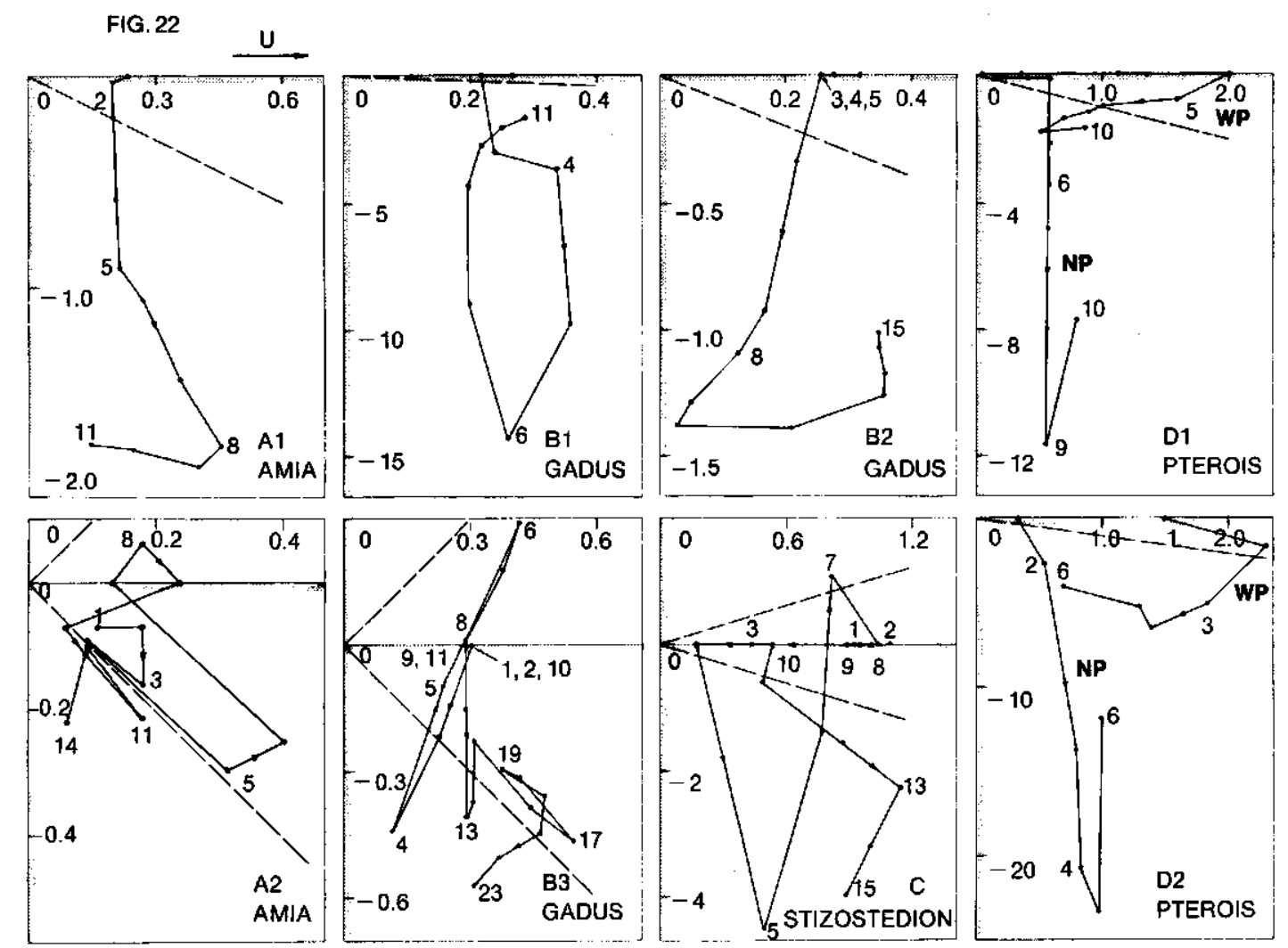

FiG. 22. ( $u_{m}, U$ )-graphs (ref. Fig. 21) for the suction process of various types of snaps of some fish species. $U$ is plotted along the abscissa, $u_{m}$ along the ordinate. Velocities are in $\mathrm{m} / \mathrm{sec}$. The animals are the same as in Plate 1, Table I. Different snaps of a species are of the same animal. Note that due to different scales the line $b=-1$ has a variable position. The time interval between the successive numbered points is $2.5 \mathrm{msec}$. The arrows indicate the direction of the suction process. $u_{m}$ is calculated from prey movements. Therefore maximum errors in $u_{m}$ are up to $50 \%$. The other maximum errors are less than $10 \%$. Even with these errors these pictures characterize the flow.

A1: Snap of Amia. This movement was so strong that the body could not be accelerated in the time available. So, a vortex-flow occurs.

A2: A weak suction movement allows the combination with swimming and shows a flow varying between a parallel stream and a vortex + parallel stream. Sometimes stagnation occurs.

B1,2: Analogous to Al but for Gadus. B 1 is a very strong movement, B2 a much weaker one. B3: Analogous to A2 for Gadus.

C: Analogous to A2 for Stizostedion. The pike-perch is able to maintain for a long time a parallel stream relative to its mouth aperture, but from time to time large deviations occur in which swimming or suction dominates (resp. points 7 and 5).

D1,2: Snaps of Pterois showing the effect of protrusion. The curves NP denote the situation if no protrusion were present. The graphs WP are the real ones occurring.

In order to obtain comparable graphs the value of $u_{l}$ without protrusion was kept approximately equal to the value of $u_{\text {I }}$ with protrusion. By protrusion thus a reduction of the impulse added to the water is achieved and also the flow relative to the mouth becomes more directed. Similar results were obtained for a comparison between a maximal constant protruded mouth and the actual case i.e. with variable protrusion. 
The following Table lists the data which allow a comparison of the above curves with the opening of the valves and the course of the entire suction act.

\begin{tabular}{lllll}
\hline graph & $\mathbf{t}_{\mathrm{b}}$ & $\mathbf{t}_{\mathrm{e}}$ & $\mathbf{t}_{\mathrm{h}_{1 \max }}$ & $\boldsymbol{\tau}$ \\
\hline A1 & 20 & 45 & 32.5 & 51 \\
A2 & 30 & 62.5 & $37.5-55$ & $41-43$ \\
B1 & 24 & 49 & 49 & 77.5 \\
B2 & 52 & 87 & 64.5 & $146-194$ \\
B3 & 42.5 & 97.5 & 62.5 & $159-182$ \\
C & 34 & 69 & 54.5 & 64 \\
D1 & 2 & 24.5 & 17 & $22-25.5$ \\
D2 & 4 & 16.5 & 24 & 27 \\
\hline
\end{tabular}

$\tau=$ time of opening of the opercular valves. $t_{b}=$ time at which the graphs begin. $t_{e}=$ time at which the graphs end. $t_{h}$ max $=$ time at which the maximum mouth aperture is reached. Times in msec. Note that the graphs end when the prey is engulfed. Opening of the valve occurs earlier (A2, C, D1) or later (A1, B1-3, D2) than this moment.

is impossible. We think however that the above description gives the essentials of the flow. Details about the transition of flow patterns however cannot be given. (For point 2, 3, and 4: see also D1.3).

Fig. 22 gives some examples for the suction process of different fish. In these examples the velocity $u_{m}$ is derived from particles moving close to the axis of the profile. Several limitations concerning the application of flow visalization techniques must be kept in mind.

Taking e.g. the quantity $\Delta b / \Delta t=$ constant as a limiting criterion, the region in which an accurate flow visualization is obtained can be directly designated in the $\left(u_{m}, U\right)$-diagram.

$u_{m}$ can be determined more accurately when a single sphere is followed in its 3-D-course. This is impossible even with film frames combining lateral and ventral views. Van Leeuwen (in prep.) has therefore developed a stereoscopic flow visualization technique.

By the combination of suction and translation of the fish together with a proper choice of the moment the opercular valves open, $t=\tau$, two important effects are accomplished:

1) The water containing the prey remains as stationary as possible in an earthbound frame.

2) Pushing the water away (in an earth-bound frame) is avoided; mostly suction is dominant.

Theoretically the two above effects can be achieved without an opercular valve. This is e.g. the case by swimming over the prey with permanently open valve (Fig. 7D). However in these cases the time needed for feeding is long and friction becomes a major factor. The water which would flow to caudal could also be stored in a flabby reservoir behind the opercular slits or forming the opercular cavities as e.g. was observed in Lophius.

Because the risk of pushing the water containing the prey is large in the very beginning of the suction act a strong initial suction movement with a closed 
TABLE V. The value of the parameter $b$ (section D3.3.2) calculated from the dimensions of the fish and calculated from the velocities of predator and prey during suction. Ref. also Fig. 22, Plate 4.

\begin{tabular}{lllll}
\hline species & $\begin{array}{l}\text { maximal mouth } \\
\text { aperture diam. } \\
(\mathrm{mm})\end{array}$ & $\begin{array}{l}\text { fish height } \\
(\mathrm{mm})\end{array}$ & $\begin{array}{l}\text { parameter } \mathrm{b} \\
\text { calculated } \\
\text { from dimensions }\end{array}$ & $\begin{array}{l}\mathrm{b} \text { about } \mathrm{t}_{\mathrm{h}_{\max }} \\
\text { from velocity }\end{array}$ \\
\hline Amia & 36 & 59 & -1.7 & +0.2 to -4 \\
Gadus & 32 & 59 & -2.4 & 0 to -7 \\
Stizost. & 39 & 55 & -1.0 & 0 to -1.2 \\
$\begin{array}{l}\text { Pterois } \\
\text { (with fins) }\end{array}$ & 26 & 86 & -9.9 & -8.8 to -11.9 \\
\hline
\end{tabular}

valve is a necessity. Opening of the valves at a later stage prevents pushing (see Van Leeuwen, in prep.).

\section{D3.3.3. The streamline of the fish}

The importance of streamline for aquatic locomotion is well known (Hertel, 1966). Also during prey capture it is important that the pressure drag is minimal when the fish advances with an open mouth. This situation is reached when the body fits the shape of the dividing streamline of the flow in front of the mouth aperture or at least falls within this streamline.*

The relation between the radius of the mouth aperture and the asymptote of the dividing streamline as a function of the parameter $a$ has been described by Muller et al. (1982). In the latter paper a constant value of $a$ has been assumed during a particular suction process (for reasons of simplicity). The moment during suction when the mouth aperture has its maximum value can be used to calculate the height providing an optimal streamline form of the fish (if $b$ is constant and negative). This relation between mouth aperture diameter and fish height is only directly applicable when a protrusion mechanism is absent. With protrusion the velocity of the protrusion must be subtracted from the velocity of the mouth aperture $(U)$ to determine $b$ and so the streamline pattern round the fish.

Table V gives some actual values of the maximum mouth aperture, the fish's height and the values of $b$ at these instants. These calculated values of $b$ do agree quite well with those derived from the velocities (cf. Fig. 22).

This means that, at least when the mouth aperture is maximal i.e. at the moment when the prey is actually captured, the streamline is such that the water flows along the fish's body and enters the mouth with minimum resistance. In other words, the pressure drag caused by the moving fish is minimal. So, at this critical

* From Fig. 6 it is apparent that the dividing streamline during suction has a greater radius about the fish than at infinity. However the relation between the height of the fish and the radius of the mouth aperture as described in Muller et al. (1982) holds because the water within the dividing streamline and the caudal free streamlines has still a considerable velocity. Only the velocity within the free streamline is very low and there the body of the fish can thus be inserted. Therefore, the effect of the expansion of the mouth on the streamlining of the fish has been neglected. 
PLATE 4

A. Engraulis

$\mathbf{b}=\mathbf{0}$

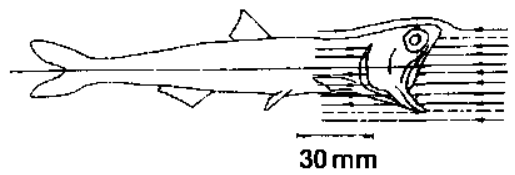

$b=0$

B. Gadus

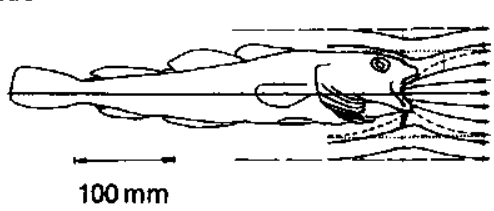

$b=-8$

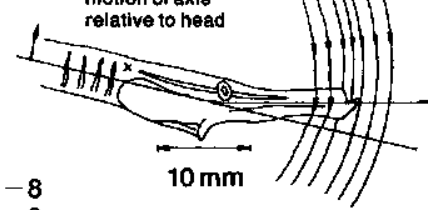

E. Macrorhamphosus

$\times$ motlon of axis

$100 \mathrm{~mm}$

C. Salmo

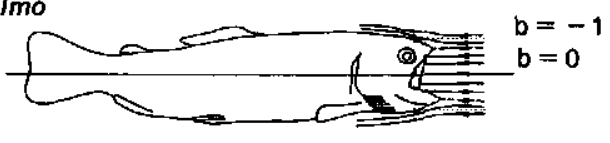

relative to head

$100 \mathrm{~mm}$

G. Pterois

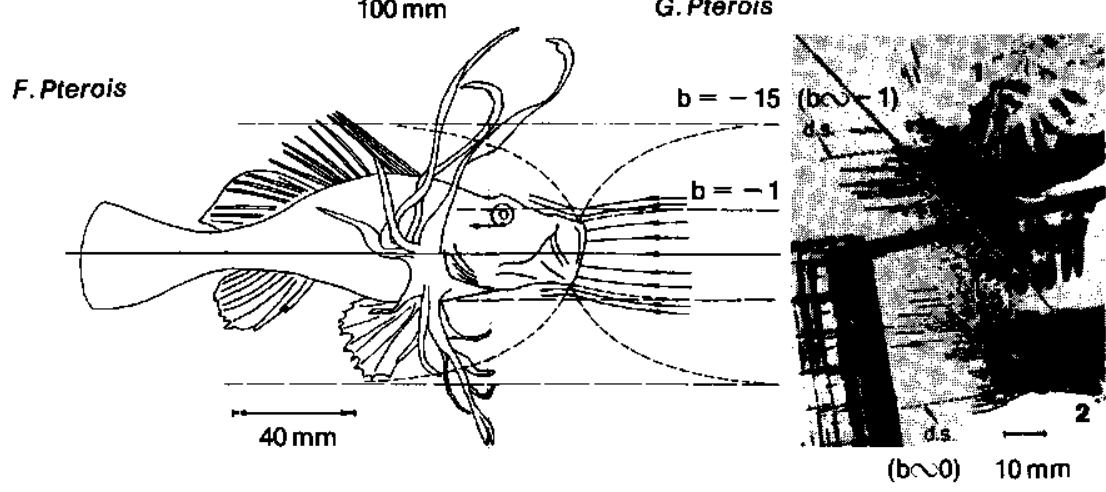

Plate 4. Flow in front of the mouth apertureand through the opercular slits compared to dimensions of the body of the fish for different types of suction feeding and filtering. The flow is shown relative to the fish's mouth aperture. The dotted and broken lines indicate the dividing streamline for different values of $b$.

A: Filtering by swimming through the water with open mouth and opercular valves.

B: High- $\tau$-suction. The flow is not directed and a large impulse is added to the water containing the prey. Average values of $b$ are 0 to -7 (at about the instant $t_{h_{\text {Imax }}}$ ).

C: Low- $\tau$-suction with swimming. The flow is highly directed and a very small impulse is added to the water containing the prey. $b$ is about zero to -1 .

$D$ : Suction with valves closed by very rapid rotation of the head. Due to the rapid translation of the mouth aperture $b$ is approximately zero and the water in front of the mouth does not move (ref. Plate 1E). The shaded area designates the region wherein the prey can be captured.

E: Analogous to D but valves early opened (not measured but observed in centriscids). Note the minute mouth aperture. When the volume of water ingested is the same as in $D$ an excursion over a larger angle can occur. On the other hand the motion must be yet more directed than in D.

F: Low- $\tau$-suction with protrusion. The body moves backwards relative to the mouth aperture. 
$b$ will be about -1 . The asymptote $b=-15$ shows the flow occurring without protrusion i.e. the flow remaining with respect to the fish's body. This flow encloses the fins.

G: Actual flow visualization in Pterois. Picture 1 shows the lateral, picture 2 the ventral side (through a mirror). The flow pattern has been reconstructed by printing three movie pictures over each other (resp. 19.1, 24.1 and $29.0 \mathrm{msec}$ ). Duration of the suction act is about $90 \mathrm{msec}$ (mouth closed). The flow has been visualized with polystyrene spheres. $d . s$. $=$ dividing streamline. $b$ varies between 0 and -1 . The diagonal line depicts the plane of the mouth aperture in the lateral picture.

moment the relation between forward speed, mouth diameter and maximum body height fit to obtain a flow along a streamlined body.

\section{D3.3.4. The flow related to the type of suction, the shape of the fish} and the construction of the mouth (Plate 4).

The separate parameters involved in suction feeding viz. head length, swimming velocity, maximum mouth diameter, maximum diameter at the valve, time courses of reaching these values, time difference between rostral and caudal expansion, streamlining of the body and opening of the valves have been treated separately or in an incomplete combination. A synthesis of all these parameters is illustrated in Plate 4 and outlined below. Although all these parameters allow an enormous amount of variation a certain classification of broadly outlined types of feeding is possible. These types are arranged in a sequence providing an increasing set of options for suction feeding (except pipette-feeding which is added as an example of a highly specialized suction system). This sequence corresponds with the classification of the orders of teleostean fishes as given by Greenwood a.o. (1966) and reflects well the adaptive levels of the feeding apparatus outlined by Schaeffer and Rosen (1961).

1) Filtering (e.g. Engraulis, Plate 4A).

$t_{h_{2 \max }}$ tends to infinity (permanently expanded mouth) and $\tau$ to zero (permanently open valves). The valves are not involved in this feeding type; so, a small width and a light construction of them will be sufficient (see below: type (3), for the opposite case). $u_{m}=0$; so, during feeding, no impulse is added to the water containing the food.

Relative to the mouth aperture a parallel stream $u_{1}=-U$ exists and the body height will approximate the diameter of the mouth aperture. The body musculature needed for swimming (and thus feeding) has to be packed up in a longitudinal direction i.e. within the asymptote of the dividing streamline. Because continuously swimming is a prerequisite to obtain the food in this way, the swimming apparatus is well developed and the body is also streamlined for this function (see Hertel, 1966).

This feeding type is restricted to the open water (O'Connell, 1972).

2) Low- $\tau$-suction with swimming (e.g. Salmo, Plate 4C).

$t_{h_{2 \max }}$ is $50-200 \mathrm{msec}, \tau \leq \frac{1}{2} t_{h_{2} \max }$ i.e the valves open relatively early (cf. Fig. 13; here and in the following the relation between $\tau$ and $t_{h_{2 \max }}$ has to be read as referred to the moment $t_{v 2}$.).

This is in accordance with the width of the valves (see D1.3.3). Because, with closed valves, the swimming compensates for the suction (see Van Leeuwen, 
in prep.), $u_{m}$ has low values or is even zero. The situation with open valves is described above (1), except for the fact that the head still carries out radial movements (see also Van Leeuwen, in prep.). Thus the impulse added to the water containing the prey during feeding is low or zero. $u_{1}$ is about equal to $-U$ and the flow relative to the mouth aperture is approximated by a parallel stream. Because the contour in Fig. $21 \mathrm{E}$ does not need to coincide exactly with the $U$ axis, stagnation and/or suction will occur at different instances during the feeding act (this has been experimentally verified by Van Leeuwen, in prep.). The body height approximates the maximum diameter of the mouth aperture. The musculature of the body is packed up longitudinally; because this feeding type requires a sudden and big acceleration (Webb, 1976), a more developed body musculature than in case (1) can be expected.

The feeding is restricted to the open water because forward swimming is a prerequisite for feeding.

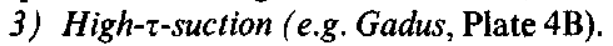

$\tau>\frac{1}{2} t_{h_{2 \max }}$ (cf. Fig. 13) i.e. the valves open relatively late. So, a great width is required to maintain contact between valves and body wall during abduction of suspensoria and opercula (see D1.3.3). Average values of $b$ are 0 to -7 (at about the instant $t_{h_{1 \max }}$ ), consequently $u_{m}$ has high values and a definite impulse is added to the water. The flow relative to the mouth aperture is composed of a vortex and a parallel stream and funnel-shaped. Also a pure vortex can occur (Fig. 22: B1, B2).

Therefore the body height can be greater than the maximum diameter of the mouth aperture. The prey can be obtained from a corner or along a substrate. In the open water low- $\tau$-suction with swimming is also possible.

4) Low- $\tau$-suction with protrusion (e.g. Pterois, Fig. 22: D1, D2; Plate 4F, G).

$\tau \leq \frac{1}{2} t_{h_{2 \max }}$ (cf. Fig. 13) and $t_{h_{2 \max }}$ is lower than $50 \mathrm{msec}$ i.e. the valves open relatively early.

The width of the valves can be small when exclusively this type of feeding is applied (e.g. Capros). When the width of the valves is relatively great also high- $\tau$ suction is possible. $u_{m}$ has low values; so, the impulse added to the water is low. Especially in fishes which have small valves and show a considerable protrusion during the suction act the gills occupy a relatively small volume (e.g. Zeus, Capros). This allows an unhampered flow to caudal through the wide opercularand gill slits.

During the feeding act large (Perca), intermediate (Pterois) or low (Capros) swimming movements are carried out in order to obtain the prey from respectively an environment in which relatively wide room is provided for swimming or one which contains many obstacles or small corners. This is concluded from direct observations of these species.

The origin of the moving frame lies in the mouth aperture. For considerations of water velocity in this frame it is unimportant whether this origin moves forward due to protrusion or due to motion of the fish as a whole. The advantage of protrusion compared to swimming is that only the mouth aperture is accelerated and the body remains rather stationary (in the earth-bound frame). So, 
not only the impulse added to the water containing the prey is greatly reduced but also a small impulse is added to the body and the water behind the fish.

Due to protrusion the velocity $u_{1}$ (i.e. relative to the mouth aperture) is very high i.e. between $-U$ and $-2 U$. Hence the time of suction can be reduced and therefore the impulse added to the water.

The effect of protrusion is shown in Fig. 22D giving the contours of the suction process of Pterois without and with protrusion. In the latter case the flow towards the mouth aperture is highly directed. This is confirmed by visualization of the flow, actually occurring during a suction movement of Pterois (plate 4G). The time in which the suction act takes place can be reduced as compared to cases involving considerable swimming $\left(t_{h_{2} \max }<50 \mathrm{msec}\right)$ because only the mouth aperture is pushed forward. Therefore the water velocity relative to the mouth aperture is high. Because protrusion occurs in the very beginning of the suction act water is being sucked with maximum mouth length.

Because the water velocity at the mouth aperture is proportional with (higher powers of) $l$ the effect of suction is increased compared to the case when no protrusion would occur. So, suction of a small volume of water with a very high velocity is possible.

According to the rate of translation of the fish's body the ratio between (maximum) body height and maximum mouth diameter runs from an intermediate value in Perca to a high value in Capros or Pterophyllum. The force required for sucking the water increases when high velocities are generated i.e. when the mouth is long and the mouth aperture is small.

This demands a well developed rostral epaxial and hypaxial musculature with e.g. long moment arms relative to the concerning head structures. This is again in accordance with a high body. The ratio of body length and maximum body height is also related to the translation of the body (swimming musculature) viz. high in Perca and low in Capros.

Fishes with protrusion mechanisms do not require extreme swimming movements to obtain a directed flow to the mouth. These fishes can thus feed in restricted spaces of the environment. Fast swimming acanthopterygians like Sphyraena do not possess a protrusion mechanism and feed in the open water. The case of Luciocephalus (Lauder and Liem, 1981) which has a strong protrusion and which also swims is discussed by Van Leeuwen (in prep.).

5) Pipette feeding. (e.g. Entelurus, Macrorhamphosus, Plate 1E. Plate 4D, E; see also D1.3.3).

The above types of suction feeding are directed along the body axis of the fish (this axis may be more or less curved as in e.g. Callionymus). Many pipefishes capture their prey by a sudden and very rapid rotation of their head (by levating their neurocranium), the mouth aperture is moved in an arc, perpendicular to the fish's main axis.

Accordingly, the velocity and the acceleration of the water relative to the mouth aperture are huge (respectively about $10 \mathrm{~m} / \mathrm{sec}$ and $1000 \mathrm{~m} / \mathrm{sec}^{2}$ for a $20 \mathrm{~cm}$ long Entelurus). Furthermore the values of these quantities increase when the snout length is greater (so, it is advantageous to increase the snout length when 
very rapid preys are to be captured). As the value of the pressure then dramatically increases (Fig. 28) the suction movements must be very forceful (this is probably accomplished by a click mechanism of the hyoid and the epaxial musculature).

Because the suction compensates the motion of the snout tip (Plate lE; so no stagnation occurs), $u_{m}$ is approximately zero and $u_{1}=-U$ ( $U$ is in this case the velocity of the mouth aperture due to rotation of the head). So, the flow relative to the mouth aperture is a parallel stream (Plate 4D, E). The flow picture drawn by Alexander (1967a) is only valid during transport of the prey from the snout tip to the oesophagus, thus during prey handling.

The comparison of feeding with protrusion and pipette feeding reveals important differences between both systems. This is the more remarkable because at first sight pipette feeders could be taken for fishes with permanently protruded mouth.

The small size of the mouth aperture in pipette feeding implies an even higher directional sensitivity than a system with protrusion. In the latter a range of prey sizes can be taken whereas pipette feeders can take only miniature food items.

Pipette feeders rotate their neurocranium very fast. This motion can be so fast because the mass to be rotated (moment of inertia), i.e. the snout, the water within it and the virtual mass, is quite low. Besides the snout is streamlined, laterally flattened in the direction of rotation. It is also advantageous to store the sucked water close to the centre of rotation of the neurocranial movement because in that case it hardly increases the moment of inertia of the snout.

Compared to feeding with protrusion two important differences exist viz. the streamline in pipette feeders is perpendicular to the long axis instead of parallel to it. Secondly the rapid dorso-rotation and the long snout allow a huge acceleration of the snout tip towards the prey.

When an equal volume would be ingested in Entelurus and Macrorhamphosus the latter will move its snout over a greater angle thus having the advantage of a larger initial distance between predator and prey. The angle of snout rotation in Plate 4E was obtained from manipulation with a fresh dead specimen and appeared to be limited by the ligament between the supra-occipital bone and the plate formed by the fused radials and dorsal vertebral processes. The camouflage generally found in pipefishes allows a close approach to the prey. Volume suction, earlier described for syngnathids (Osse and Muller, 1980), applies only to the whole feeding act including a long period of prey transport from the mouth tube to the oesophagus, but the initial food suction is very rapid and deals with a very small volume of water and with a low impulse added to the water containing the prey.

So this term is not adequate for the initial capture of food in syngnathids because the fast initial suction is a main feature of its specialization. The relation between pressures, construction of the gill cover and the shape of the gills as we described earlier remains valid. The advantage of a system with permanently closed valves as found in syngnathids is still unknown. 
Summarizing the above types of feeding in teleosts we conclude that snout length, protrusion, snout diameter, head expansion, swimming, prey size, initial distance of the prey to the snout tip and also the construction of the gill cover (see D4.4.1), the shape and opening of the valves (see D1.3.3), the shape of the gills (see Plate 3, Plate 5), and the size and action of the epaxial and hypaxial muscles form a closely interrelated set of form and motion characters (ref. Fig. 13,17 and 22).

Many other types of suction like those of bottom-dwelling Cypriniformes and Siluriformes, and also highly extreme ways to obtain the prey like oral shelling or paedophagy of Cichlidae (Barel, 1980) fall outside the scope of this study because the time course and the movements carried out suggest that hydrodynamical constraints are not primarily responsable for the morphological specializations.

\section{D3.4. The flow behind the profile}

When the opercular and branchiostegal valves open, water flows from the opercular cavities through the opercular slits to caudal in all the 20 suction acts of Pterois we analysed, relative to the moving frame (with origin at the opercular slits). Also in Platichthys (6 sequences) such a caudal flow occurs.

As discussed in D2.3.2 a small inflow, just after the opercular slits have been formed, is possible. This flow has been actually visualized by Van Leeuwen (in prep.) for Salmo gairdneri. Lauder (1980b: p. 67) mentioned a caudal inflow just after the opening of the valves in Lepomis. However he omitted to refer to the frame in which this flow occurred. At that instant the fish had a particular velocity (in an earth-bound frame) which might be higher than the velocity of the particles towards the opened opercular slit. His conclusion that inflow really occurs (in the moving frame) does therefore not follow logically from his observations.

A flow originating from an aperture is forming a jet bound by free streamlines (Milne-Thomson, 1968: Ch. XI). As illustrated in Fig. 6 this holds also for the case of the feeding fish. Free streamlines change their position when a pressure difference exists about them. Because we deal with unsteady flow such a streamline may move against a pressure gradient (see $\mathrm{C} 2$ ). The free streamlines constantly diverging i.e. moving to lateral and ventral behind the opercular slits of Pterois were shown in Muller et al. (1982: Fig. 9A). The conclusion is therefore justified that here the pressure inside the jet is higher than the pressure outside the jet. As the pressures behind the open valve can not be quantitatively derived from the flow there we choose the boundary condition from the velocity.

\section{D4. THE PRESSURES.}

\section{D4.1. The components of the pressure}

Calculation of the pressure requires the solution of the equation of motion (see C2). In this equation the pressure is composed of a velocity- and an acceleration term. 
In the earth-bound frame the pressure in the centre of the moving vortex was calculated to provide a boundary condition for the calculation of the pressures inside the profile. The forward motion of the profile causes an extra acceleration term and a mixed term (Muller et al., 1982: p. 67). Hence, the actual pressure is composed of six terms as is shown in the example of Fig. 24. The pressures are only calculated for zero- or negative values of the parameter $b$ i.e. in the fourth quadrant of the $\left(u_{m}, U\right)$-plane (Fig. 21). For $b>0$ the external flow changes and the vortex approximation has to be adapted. Note that pressure calculation in the fourth quadrant includes suction and swimming.

The equation of motion is a second order differential equation and its solution therefore requires two boundary conditions (either a velocity and a pressure or two pressures or velocities). For the flow concerning the moving vortex these conditions are $u=0$ and $p=p_{0}$ for $x=\infty$ (i.e. in the earth bound frame, at a great distance of the vortex the water velocity is zero and the pressure is equal to the ambient pressure). For the internal flow with valve closed the boundary conditions in the frame moving with the fish are $u_{v}(0, t)=0$ and $p_{v}(l, t)=p_{m}$ (i.e. the water velocity at the valve is zero and the pressure in the mouth aperture is equal to the pressure in the centre of the vortex). It has to be remarked that, for reasons of simplicity, no account has been taken for the protrusion. So, the length of the fish's head has been assumed to be constant and the velocity $U$ of the entire profile has been referred to the mouth aperture.

When the valve is open the boundary condition $p(l, t)=p_{m}$ holds but $u(0, t)$ is no longer defined. It proved to be very difficult to choose a second boundary condition for this case (Muller et al., 1982; Van Leeuwen and Muller, in prep; D2.3.2). The value of the pressure will be greatest in the very beginning of the suction process when the volume of the mouth is still small. In all the cases we studied by simulation and also in the experiments (see D4.3) the maximum values of the pressure and the major peaks occur before the valves have been opened. So, the mechanical load to the fish's head and some conditions for opening of the valve can be derived from the pressure occurring with closed valve. This condition is used in the next sections.

FIG. 23

$$
\begin{array}{cc}
\multicolumn{1}{c}{\begin{array}{c}
x=0 \\
\text { "opercular region" }
\end{array}} \\
\hline
\end{array}
$$

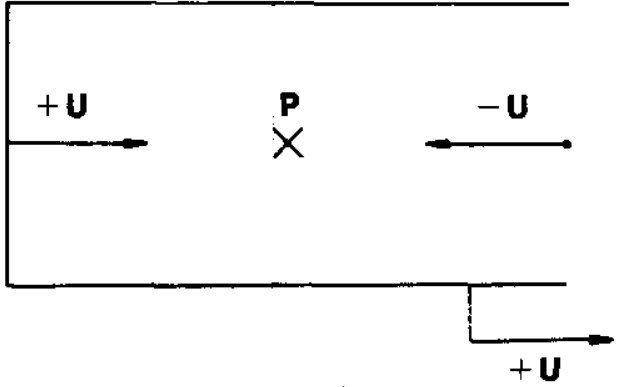

Fig. 23. The point of zero flow in an earth-bound frame results from a combination of suction by mouth expansion and pushing by translation of the body. Further explanation in section D4.2. 


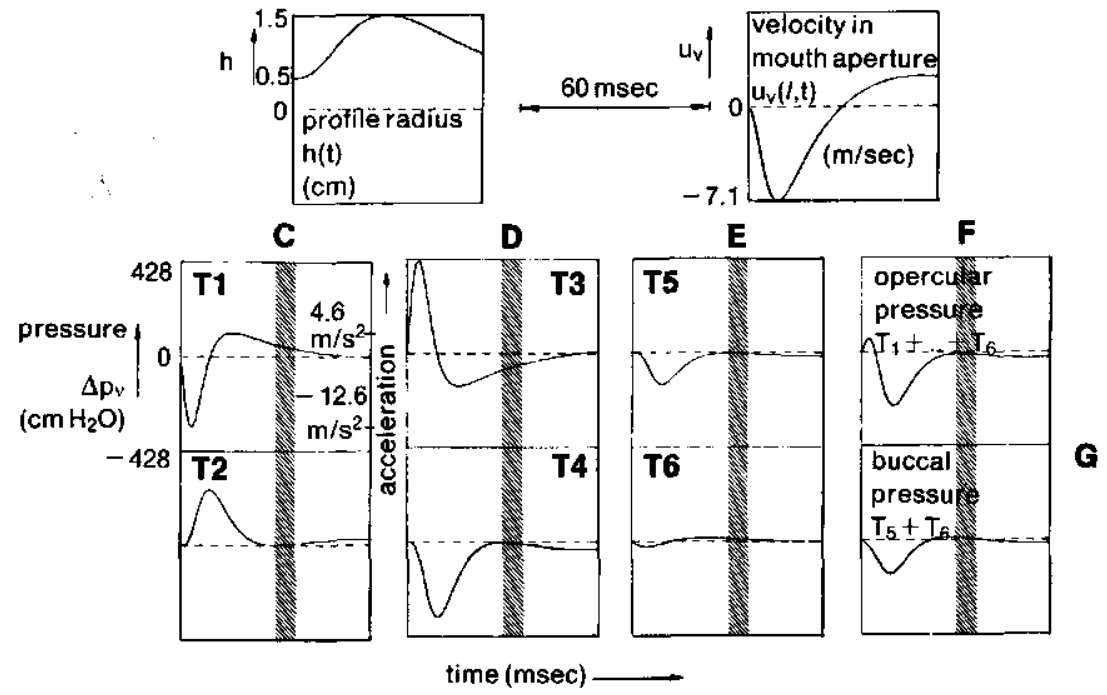

FIG. 24. Components of the pressure, $\Delta p_{v},\left(\mathrm{~cm} \mathrm{H}_{2} \mathrm{O}\right.$; all on the same scale) generated by a cylindrical profite, sucking itself forward $(a=0.5)$. Valves closed.

A: profile radius, $h(\mathrm{~cm})$.

B: velocity in mouth aperture, $u_{v}(l, t)(\mathrm{m} / \mathrm{sec})$.

$\mathrm{C}$ : internal pressure components at $x=0 ; \mathrm{T} 1$ : acceleration pressure, $\mathrm{T} 2$ : positive velocity pressure (Bernoulli). The acceleration in the mouth aperture follows the same curve as in $\mathrm{T} 1$. Values of this acceleration are indicated at the right side of the graph.

D: Pressures due to translation along the axis of the profile (at $x=0$ ); T3: positive acceleration pressure, T4: velocity pressure (mixed term).

E: Pressures at $x=l$ of the external flow, vortex + parallel stream; T5: velocity pressure, T6: acceleration pressure $\left(u_{l} h_{l}\right)^{\prime}$.

$\mathrm{F}$ : opercular pressure $(x=0)$ equal to sum of all components.

G: pressure at the m.a. $(x=l)$ equal to T5+T6. The cross-hatched bars indicate the time after which the pressure calculation becomes inaccurate.

For formula: see Appendix I.

\section{D4.2. The pressure as a function of the time}

Consider a fish sucking itself forward in an earth-bound frame with closed valves. Let the value of $b=-l$ i.e. the water velocity in the mouth aperture $u_{m}$ is equal but opposite to the velocity of the mouth aperture $U ;\left(u_{m}=-U\right)$. Because protrusion is neglected the water velocity at the valves is $+U$ and halfway the mouth no water is moving (Fig. 23). Because the fish is moving, the latter point changes its position continuously in the earth-bound frame. Note that in the moving frame the point of no water flow is at the opercular valves.

So the opercular valves are pushing water in a forward direction in an earthbound frame when water is sucked into the mouth. When the expansion of the mouth has just started, the mouth aperture is still small and consequently the 
acceleration of the fish due to suction high. This acceleration causes a positive pressure at the operculars (Fig. 24: T3). Due to expansion a negative acceleration pressure will occur at the same site (T1). The value of the acceleration pressure at that site which is initially by far the greatest of all pressure components is the sum of these pressure terms and thus depend on the ratio between translation and expansion.

For the cylinder, in the case for $b \in[0,-I]$, therefore a positive initial pressure is found at the operculars. Therefore a mechanism is required to keep the valves

FIG. 25

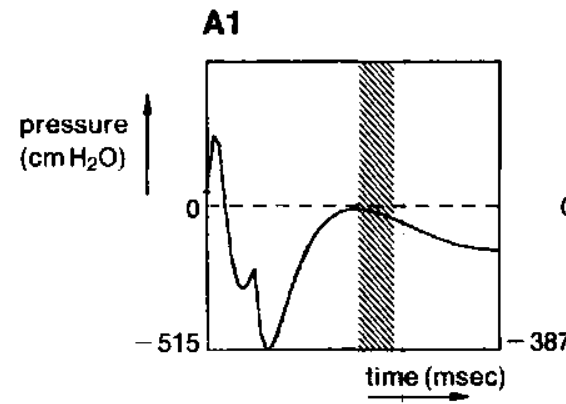

B1

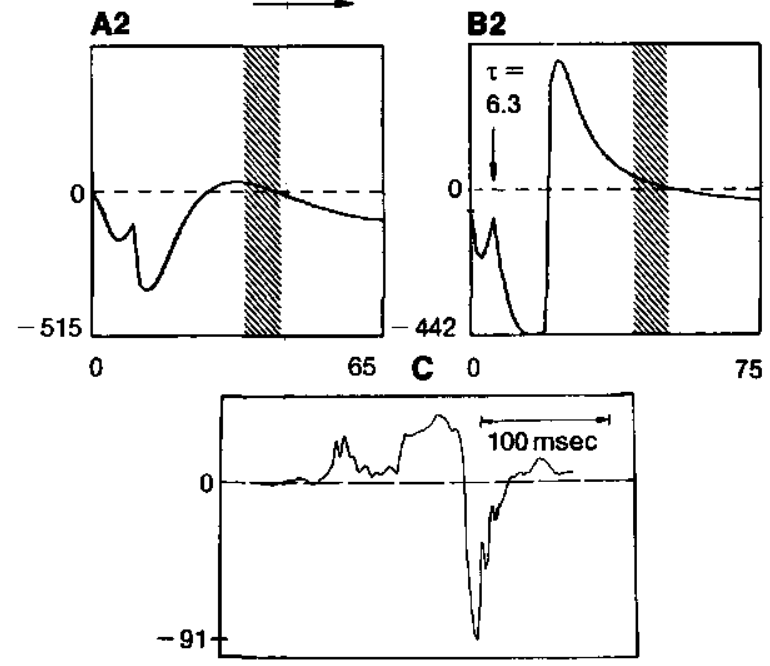

FIG. 25. Examples of pressure waveforms generated with a cone model. Pressures are indicated in $\mathrm{cm} \mathrm{H}_{2} \mathrm{O}$. The cross-hatched bars mark the time after which pressure calculation is unaccurate. A: Pressures of a simulation with a great translation-acceleration $(a=I)$. Al: opercular pressure $(x=0)$ showing the positive acceleration pressure followed by a negative phase. $\mathrm{A} 2$ : corresponding buccal pressure $(x=l)$ running from zero to negative values.

B: A simulation with a very small translation acceleration $(a=100)$. B1: "biphasic" opercular pressure due to asynchronous buccal and opercular expansion. The pressure first runs negative and shows several oscillations. B2: the same case as in B1 but now the valves open at $t=\tau=6.3 \mathrm{msec}$. C: Opercular pressure actually measured in a trout ( $\mathrm{Salmo}$ ); bandwidth $5 \mathrm{kHz}$ (Van Leeuwen and Muller, in prep.). Positive pressures are due to acceleration by swimming and by suction when the opercular valves are still closed. 
closed during this period. This is provided by activity of the $\mathrm{mm}$. adductores operculorum, as recorded by Osse (1969), often resulting in a slight adduction of the opercula (see Fig. 11). Lauder (1980a, b) did also report this adduction but lacked the data about the pressure components to give a logical explanation of this phenomenon. Nevertheless this single observation resulted in a statement about the general occurrence of biphasic activity of the $\mathrm{m}$. adductor operculi in all actinopterygian fishes (see section $\mathbf{E}$ : footnote).

The positive pressure peak at the operculars is soon outweighed by the negative velocity pressures due to the continuing expansion of the head. The acceleration pressure is related to the second derivative of the head excursion. Therefore it fluctuates more rapidly than the velocity pressure.

So, because the motion of the head is in the case of the cone modelled by two independent functions of the time, the pressure may show several lumps (Fig. 25). This figure also shows some other examples of the waveform of the pressure. We like to emphasize that the occurrence of positive pressure peaks does not imply that the direction of the flow is reversed (see $\mathrm{C} 2$ ). Therefore the explanation of the flow based on comparison of recorded pressures as given by Lauder $(1980 \mathrm{a}, \mathrm{b})$ is incorrect. This is also the case for his explanation of the pressure waveform by the "water-hammer-effect" because the pressure fluctuations concerned can also be generated when the mouth aperture does not close at all, and are evidently a direct consequence of accelerations of the head during suction.

The above description of the pressure as a function of the time is a general outline. The actual pressure waveform is subject to variation of the parameters which determine the shape and the motion of the fish's head during the suction process. When e.g. $b=0$ the positive pressure peak due to forward acceleration of the fish is maximal.

When $b$ has a large negative value this peak is small or absent. Large positive initial pressure peaks during extensive swimming have been reported by Lauder (1980b) for Lepomis and by Van Leeuwen and Muller (in prep.) for Esox and Salmo.

The fish may stress the muscles involved by the expansion of the head still keeping its mouth aperture closed. Then no flow is possible and a high negative pressure will be generated (b.e. in Fig. 25). Opening of the mouth results then in an enormous initial acceleration of the water into the mouth aperture. Thus, a negative pressure peak may precede the positive pressure peak due to acceleration of the fish. An analogous phenomenon may occur when suddenly a muscle activity is added to the running head motion e.g. a sudden abduction of the opercula (o.e. in Fig. 25), a sudden depression of the hyoid (see Elshoud-Oldenhave and Osse, 1976: p. 418). Till now we did not record such pressures. Note also the big differences which would occur between situations with closed (Fig. 25: B1) and open valves (B2).

\section{D4.3. The pressure distribution inside the mouth}

The pressure distribution inside the mouth is shown in Fig. 26A, B. The pres- 
FIG. 26
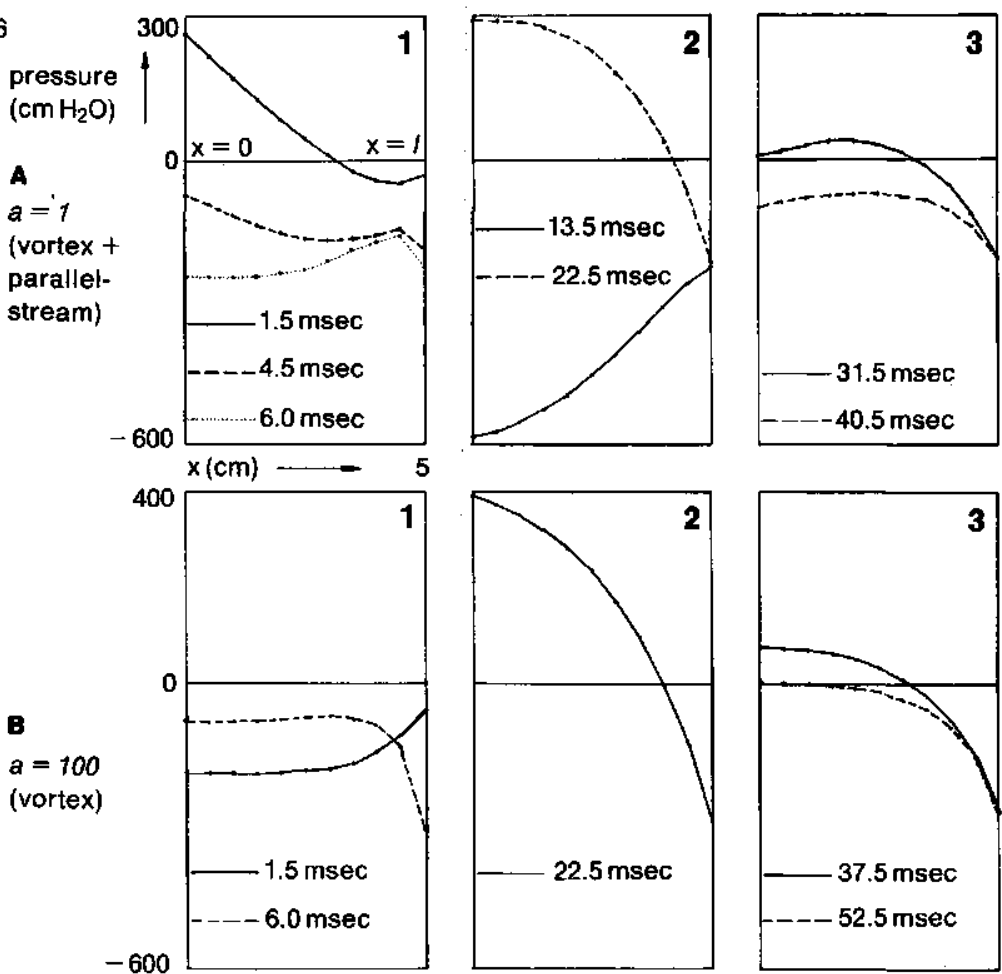

FIG. 26. Pressure distribution over the profile inside the mouth with opening of the opercular valves. Mouth length $5 \mathrm{~cm}\left(x=\eta\right.$. Velocities always negative. Pressures in $\mathrm{cm}_{2} \mathrm{O}$. The pressures, depending on the instant, are positive in the opercular region and negative in the mouth aperture or the opposite. Also the ratio in magnitude between opercular and buccal pressures is highly variable. $A$ and $B$ are separate simulations only differing in choice of the parameter $a ; 1,2$ and 3 represent successive moments during feeding acts.

sure distribution at later instants is in this figure represented in the successive pictures 1, 2 and 3. So, the pressure in the buccal cavity may be opposite to, equal to, lower than and higher than the pressure in the opercular cavities (due to the unsteady character of the flow). These results are consistent with the data obtained by Alexander $(1969,1970)$, Casinos $(1973,1974)$, Osse (1976), Van Leeuwen and Muller (in prep.) and Lauder $(1980 \mathrm{a}, \mathrm{b})$. It is apparent that the pressure distribution inside the mouth is also highly dependent on the suction movement carried out (Fig. 26). Hence, it is impossible to construct a valid model of the suction process based on pressure recordings (Lauder 1980a, b). This is also evident from Fig. 10.

The recording and interpretation of pressures is treated elsewhere in detail (Van Leeuwen and Muller, in prep.). Here only an example of an opercular pressure of the trout (Salmo gairdneri) is given in Fig. 25C. In this example the positive acceleration pressure and the oscillations in later phases of the nega- 


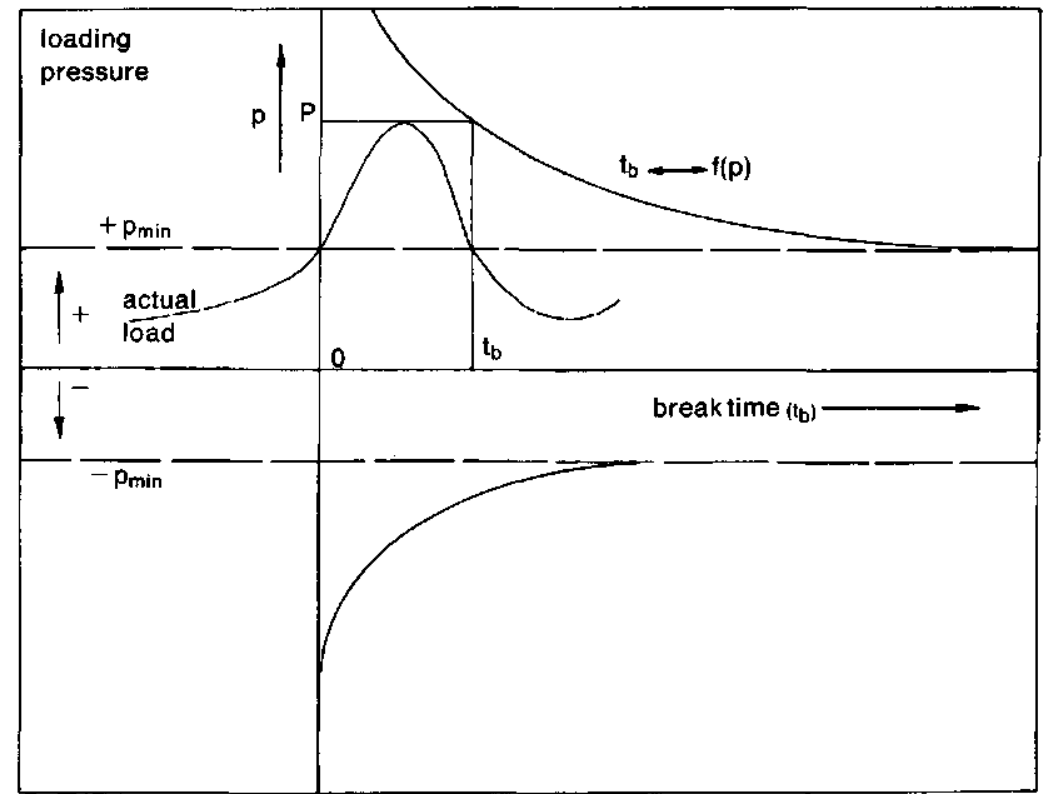

Fig. 27. Relation between loading pressure to e.g. an operculum and break time.

A structure subjected to a mechanical load deforms till it breaks. This means that a short-during load with a much higher value than a constant load may be applied to the structure without resulting in damage. So, when no damage may occur, a loading pressure $p(t)$ with a maximum value $\mathrm{P}$ may be at least a time $t_{b}$ above the pressure $p_{\min }$ which is the loading pressure which may be constantly withstood by the structure (see section D4.4.1).

tive pressure are apparent. This is a recording with a Millar transducer (see B4) giving accurate amplitude and phase details over a bandwidth of $0-5 \mathrm{kHz}$.

\section{D4.4. Pressure and fish head construction}

\section{D4.4.1. The mechanical load on the fish's head}

During the suction process the head structures are subject to very rapidly fluctuating pressures. The resistance to such an unsteady load may be largely different from the resistance to a constant load. This is explained as follows.

When a structure is loaded, it deforms till it breaks. The relation between the magnitude of the load and the instant at which the structure collapses is qualitatively sketched in Fig. 27 (Hoff, 1967; Koning and Taub 1933; Taub, 1933).

The pressure distribution occurring during suction inside the fish's mouth changes drastically as a function of the time. Therefore it is hardly possible to designate which structures of the head are most heavily loaded.

Fig. 28A gives the relation between pressures and profile length obtained from model simulations, leaving all other model parameters constant. Taking a cer- 
A

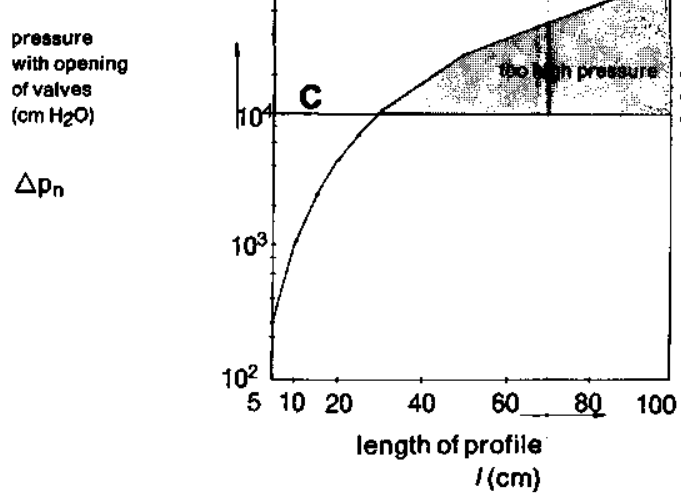

B

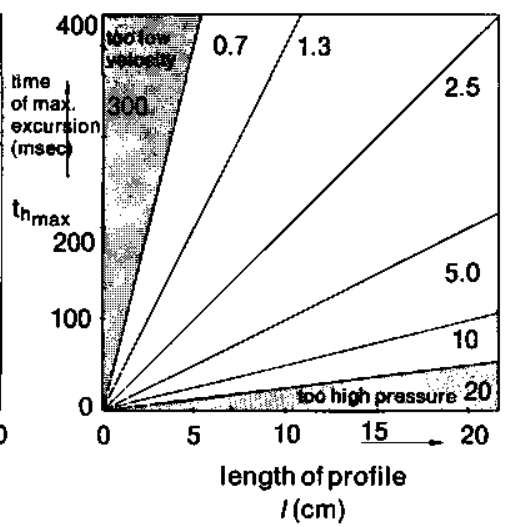

Fig. 28. A: Peak pressure as a function of profile length (from Muller et al., 1982). Above the arbitrary criterium $\mathrm{C}$ the construction of the head is too heavily loaded.

B: Velocity into "mouth aperture" of a profile with a definite size as a function of the profile parameters: mouth length $(l)$ and time of maximum excursion $\left(t_{h_{\max }}\right)$. The shaded areas indicate the probable regions where either the pressure becomes so high that the profile can not carry out any movement or is damaged, or the velocity too low to capture the prey.

tain criterium $C$ for the maximum pressure, a maximum mouth length results. Fig. 28B shows an analogous case, yet for the variation of two parameters. Here, the criterium $C$ allows the attuning of both mouth length and head motion. Another criterium of successful prey capture i.e. a minimal velocity of $0.7 \mathrm{~m} / \mathrm{sec}$. is added. In this way a range of possible suction processes is obtained by changing only these two parameters. When the limitations for the other concerning parameters are added the available range can be made very narrow. These theoretical considerations are fully confirmed when they are compared with the experimental data given in Fig. 13, 17 and 22.

The alteration of a single parameter (e.g. length, isometrical enlargement, expansion rate, initial mouth diameter, the parameter $b$ ) demands the change of all other parameters and results in a completely different suction process. Therefore it is possible to reconstruct for certain cases the entire suction process from only the head form (Van Leeuwen, in prep.).

Fig. 28A indicates that the maximum possible head length is about $30 \mathrm{~cm}$.. When the movements are slower (Fig. 28B) greater headlengths are possible. Together the conclusions point to a maximal headlength of sucking teleosts of about $40 \mathrm{~cm}$. Other feeding strategies e.g. filtering must be applied above this limit. As the pressure increases dramatically with a greater headlength in a growing fish, it is expected that the suction process must change with growth.

It has to be remarked that the above reasoning holds for the "maximal" suction process i.e. the process which takes place at the limit of the physical possibilities. The "actual" suction process is, within this limit, determined by the behavioural interaction of the predator and the prey. 


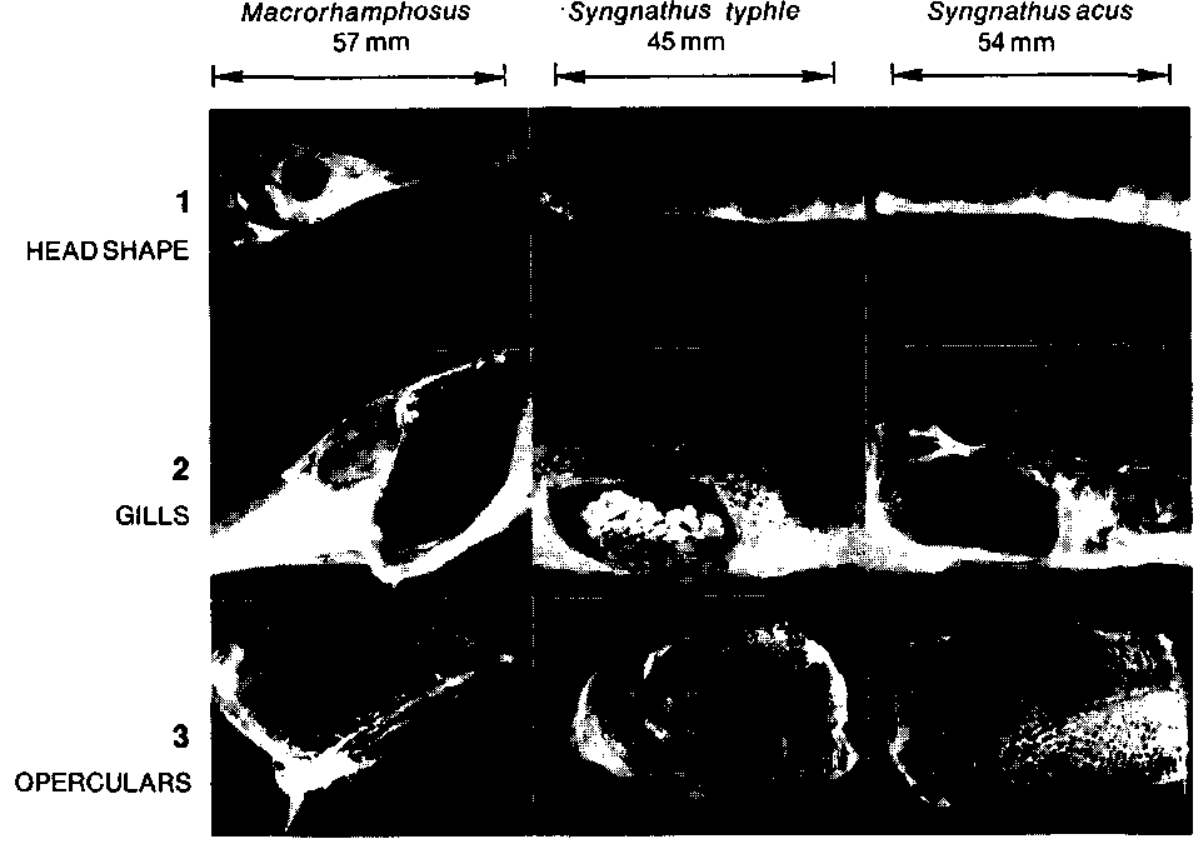

Plate 5. Head structure versus snout length.

In Synghnathus acus (C) the mouth tube is very long and narrow. Thus, the pressure inside the mouth reaches a high value during suction. Therefore the construction of e.g. the gill cover is very rugged (trabecular structure with ridges; great curvature).

When the snout is shorter and wider as in e.g. Synghathus typhle (B) the construction of the gill cover is less heavy. The fishes mentioned suck with opercular valves permanently closed. So, a streamlined shape of the gills is not necessary. Actually the gills are lobe-formed.

In Macrorhamphosus (A) the outflow from the opercular slits probably plays an important role and the valve will be opened early in the suction act. Because the resistance of the water flowing to caudal has to be low, the gills are highly streamlined. The gill cover is very thin and delicate in this case according to the low load when the valves are still closed. After the valves have been opened they will move due to the flow.

Thus, by studying such actual suction processes it is quite difficult to test whether the physical criteria, limiting the range, are well chosen.

An example of a strong variation of the parameters involved by the suction is found in the group of the Syngnathiformes. As mentioned these fish transport their prey during the second phase of the suction movement (see D1.3.3) from their snout tip to the oesophagus. This suction takes place with closed opercular valves. As mentioned above the pressure inside the opercular cavities will reach a higher value when the snout length increases (Fig. 28A). Comparison of species with different snout length shows that the construction of the operculars (ridges, curvature, thickness) is heavier when the snout length is greater (Plate $5 \mathrm{~B}, \mathrm{C}$; see also Osse and Muller, 1980). Here the effect of the variation in snout length on the pressure outweighes the compensation achieved by adjustment of the 
other concerning parameters. The peculiar structure of the gills has to be studied to determine if they are adapted to withstand these high pressures.

\section{D4.4.2. The opening of the opercular and branchiostegal valve}

During the suction movement the pressure at the (closed) opercular and branchiostegal valves fluctuates several times rapidly from negative to positive values and vice-versa. As the opening of the valves is an important event in the suction process (see D1.3, D2.3) the question is raised whether the instant $t=\tau$ is influenced not only by the expansion of the head but also by the water motion at the valves. The facts that during suction movements of some advanced fish species (e.g. Pterois) the valves open very rapidly i.e. within $2.5 \mathrm{msec}$. (see Fig. 11,13 ) and that the outflow is constantly diverging after $t=\tau$ (so the pressure is slightly positive inside the jet) suggest that tensions in the involved muscles (hyo-hyoideus inferior and superior, dilatator operculi and also the other expansion muscles, see Osse, 1969: Fig. 21) are built up and the valves open suddenly by the motion of the water. The advantage of this strategy is that, just before $t=\tau$, the velocity relative to and inside the entire profile (except $x=0$ ) was negative and the acceleration was acting in the same, negative direction thus providing an increase of the velocity in that direction. When the acceleration changes to a positive direction, the valve would be opened. So, due to the choice of such an opening time, the water streams outwards through the opercular slits because at $t=\tau$ the acceleration is zero (Fig. 24), the negative velocities average over the profile, (and are added to the flow due to swimming) and the braking influence of the positive accelerations, which would occur after $t=\tau$, is avoided. Another advantage of such a strategy is that a highly accurate timing of the actions of the muscles opening the valves is not required.

So, initial actions during suction feeding can in this way control accurately later events thereby optimizing the effects in terms of higher velocities and greater amounts of sucked water (in the moving frame).

\section{E. Discussion.}

The basis for this study forms the classical paper of Schaeffer and Rosen (1961). The highly complex form of the fish's head was related to the function, and the evolutionary change of the form was interpreted as an adaptation to the demands of a more and more predaceous way of feeding.

Alexander $(1967 \mathrm{a}, 1967 \mathrm{~b}, 1969,1970)$ presented the first quantitative approach to the suction feeding function by measuring pressures and treating the protrusion.

He also constructed, for the first time, some models concerning both suction and protrusion. However, as he remarked, his approach has to be regarded cautiously because the required approximations were kept as simply as possible (e.g. the effect of opening of the opercular and branchiostegal valves was not taken into account). 
Osse (1969) supported the study of fish head morphology by applying for the first time EMG-techniques in order to determine the actions carried out by the muscles during feeding. He stressed that a lot of parameters (e.g. the contractions of at least 15 pairs of muscles) are causing and influencing the motion of the fish's head during suction.

Additionally, he argued that the fish's head morphology with moving walls and bottom and protruding jaws is a system adapted to the feeding function, even in details as rounded-off lips.

Osse $(1973,1976)$ pointed out the importance of the branchiostegal apparatus for the feeding function.

Elshoud-Oldenhave and Osse (1976) and Elshoud-Oldenhave (1979) demonstrated the presence of different feeding strategies when different types of preys in different positions are captured for ruff (Gymnocephalus) and pike-perch (Stizostedion) (see also D1 1.3.2). However the interpretation of pressure, presented in the first paper, is still based on steady flow and therefore incorrect.

The contribution of Weihs (1980) did not help to obtain more insight into the suction process than already given by Alexander. His calculations deal merely with a combination of a sink and a parallel stream and not with a sucking and swimming fish. A reasoning leading from this model to a fish and estimates about the reality value of this model are lacking! So, e.g. the size of the mouth aperture (as a function of the time) is not defined, a constant flow through this aperture has been assumed, the opening of the valves has been overlooked, the effect of suction forward has not been taken into account, the balance between suction and swimming has not been mentioned, the protrusion has not been regarded, the contraction of the flow and the possibility of stagnation have been overlooked. This makes the relation with fish quite obscure.

The approach of Lauder (1980a, b) has already been discussed in C1, C2, C3.5, D1.3, D3.2, D4.2. Although interesting experimental data are provided the lack of fundamental insight into the effects of unsteady flow greatly reduces the value of his interpretation.

The present approximation of the suction process of fish stretches from calculations, applied to a simple cylinder, to the interpretation of behavioural patterns for capturing the prey. This approach provides:

1) A method giving a survey of important quantities concerning the suction, which can be actually measured (ref. e.g. Fig. 13, 17 and 22).

2) Results which can be tested in the actual situation e.g. results which can be falsified (like the statement that low- $\tau$-suction with swimming and protrusion do not go together).*

3) Results which deal with the suction process in its entirety like a) the coupling of the external flow with the unsteady flow, generated by the head expansion, b) its effect on forward suction, $c$ ) the forward swimming and d) the opening of

* An example of a statement which can not be falsified is the action of the adductor operculi in palaeoniscoids as hypothetized by Lauder (1980c: p. 312): "adduction of the operculum occurred in a biphasic pattern during the strike, the first phase occurring at the start of buccal expansion and the final phase following closure of the jaws." 
the opercular and branchiostegal valves.

All these events are joined in one complete view of suction feeding.

A difficulty arising from simulations with a model is that the results of these simulations can not directly be checked by measuring exactly corresponding fishes.

For example: the effect of change of profile-length on water velocities and pressures can be studied by model simulation. To compare these results with the suction process of e.g. a series of Syngnathiformes with different snout length also the accompanying differences in size and head motion must be taken into account.

This is extremely difficult as the distinction between effects due to parameter variation and effects due to compensating activities of the animal studied can not be made.

The model as well as the experiments, carried out to verify it, are subject to physical limitations. The number of parameters in the model may become too large or the calculations too complex. Also an experimental check is limited because our transducers distort the quantities to be measured. In the case of motion analysis distances can not be measured sufficiently accurately to obtain reliable values of accelerations.

However, when model and experiments consistently confirm each other in many different aspects of the process the validity of this view of the suction process is evident.

The energy spent during suction can only be estimated roughly because quantity and impulse of the moved water are unknown and also energy is used for swimming at the prey. Roughly the energy required for sucking of $1 \mathrm{~kg}$ water with a velocity of $10 \mathrm{~m} / \mathrm{sec}$ is only $50 \mathrm{~J}$ (ca. $10 \mathrm{cal}$ ). This is a very small quantity compared with e.g. the energy spent by the fish for the production of eggs (both energies taken over a year). Therefore we did not yet pay much attention to this subject. The relation between spent and taken-up energy starts to play a role when suction movements are carried out very frequently, combined with a continuous swimming activity, as in e.g. many characids and especially in young fishes.

The present model is a powerful tool to investigate the way in which adaptations are accomplished. Because of its sensitivity to changes of the parameters it provides limiting criteria from pressure and water velocity for head construction.

Furthermore, by regarding the effect of the variation of a single parameter to the other ones, the consequences of the adaptive alteration of this parameter can be studied (see D4.4). Therefore the model can be applied to judge the adaptive significance of morphological features in fossil fishes.

The model provides also insight in the different strategies of suction (see D1.3, D3.3, D4.4, Table IV). So, the difference of the feeding behaviour of the ruff and the pike-perch (see Elshoud-Oldenhave and Osse, 1976 and Elshoud-Oldenhave, 1979) can be easily explained with the model (see also Van Leeuwen and Muller, in prep.): 
Because the ruff possesses a well developed protrusion mechanism it is able to capture its prey from the open water (by high- $\tau$-suction) but also from a corner or from the bottom (by low- $\tau$-suction with protrusion). The pike-perch only obtains its prey by suction, coupled with biting in the open water; a delicate protrusion mechanism would be easily damaged by this feeding behaviour.

The difference in morphology and feeding behaviour of the, at first glance highly similar, sand-eels (Hyperoplus and Ammodytes; see Kayser, 1961) can probably also be explained in an analogous way.

The hypothesis of optimal design also designated as the minimum principle states that the minimal amount of material and energy has been applied for the construction of a structure adapted for a specific action. In our case of the suction mechanism we are able to quantify the action in terms of e.g. the velocity of water containing the prey flowing into the predator's mouth. The question arises for what level of intensity of action head structures are designed.

When training leads to considerable increase in performance as e.g. in the case of skaters (cf. Van Ingen-Schenau, 1981) the conclusion is unavoidable that during this training also morphological parameters of the construction changed to allow the increased performance. The constructional demands for a specific function must be investigated from a viewpoint of "close to optimal design" in which notion the direct response of the structure to increasing or decreasing demands of action must be included.

Finally it has to be remarked that the suction movement is not only determined by the coordinated muscle activity of the predator but also by physical restrictions of water motion and the pressures (the "hydrodynamical conditions"). Hence, if an evolutionary alteration of a structure (e.g. mouth length) changes these hydrodynamical conditions, this requires also a change of muscle actions. It also involves changes of the other parameters describing the fish's head morphology and motion; see D4.4). This process remains in swing until a new equilibrium is reached thus representing a different feeding pattern (ref. D1.3). 


\section{F. Acknowledgements.}

We wish to thank Ir. J.L. van Leeuwen for many discussions and suggestions. He also took the films of Amia, Salmo, and Platichthys.

We are indebted to Ir. J.H.G. Verhagen for excellent advise concerning the hydrodynamics.

Ir. M.R. Drost carefully analysed many fish head- and prey-motions and gave valuable comments about the parameters $a$ and $-b$.

Mr. A. Terlouw, Mr. B. van Schie, Mr. A. Ramakers and, again, Mr. van Leeuwen assisted with the experiments.

Mr. W.A. Valen assisted with photography and made some complicated drawings.

Mrs. Drs. M.J.W. Elshoud-Oldenhave is acknowledged for her permission to publish the scene of Stizostedion.

Our colleagues of the Department of Experimental Animal Morphology and Cell Biology are acknowledged for their contribution.

Much of the writing of this manuscript was supported by a grant from the Netherlands Organization of Pure Research (Z.W.O), obtained through BION (Biological Research in the Netherlands). 


\section{SUMMARY}

1. Suction feeding is the dominant way to obtain food in teleosts. Its high demands on structures due to the required velocities and forces leads to the expectation that a biophysical analysis will aid to reveal the adaptive significance of head and body structures related to this action.

2. A main factor in the development and perfection of mechanisms of prey suction is the pushing of water and prey by the approaching predator due to the high density of water.

3. To obtain the prey only the flow relative to the predator is important. This flow consists of components caused by suction, by forward motion due to suction and by swimming. Flow velocities are therefore calculated in the frame of the moving fish. They differ from flow measured in an earth-bound frame e.g. the aquarium. The distinction of these two systems of coordinates is an essential feature of the present approach.

4. A model is developed of flow in an expanding and compressing cylinder or cone, possessing an anterior opening ("mouth aperture") and a posterior expanding region ("opercular") with a moving branchiostegal- and opercular valve. The simplifications necessary in the fish to model transition are examined on their applicability. This is done for hydrodynamic (e.g. the role of friction) as well as for biological (e.g. influence of gills) abstractions.

5. The model features the interrelation between shape and movement of mouth aperture and opercular region, the moment of prey swallowing and valve opening, the influence of translation on the flow and the unsteady nature of the generated flow.

The distinction of a point of zero flow in an earth-bound frame facilitated the construction of streamlines and is a point of reference for the calculation of pressures.

6. The analysis of actual fish head motion from high-speed movies and the use of these measurements in model simulations necessitated complex procedures of curve fitting.

7. The flow in front of the fish towards its mouth, inside its buccal cavity, behind the valves and around the rest of the fish is united in one comprehensive flow picture. Problems of boundary values which must be chosen to describe the frontal and caudal flow are discussed.

8. To capture the prey the optimization of the amount of sucked water and of the velocity of the water into the fish's mouth is requested, together with a directed suction flow reducing the amount of sucked water not containing the prey. The former is increased when continuing head expansion can be performed with closed valves thus maintaining an antero-posterior flow. This solution requires long and rotatable branchiostegal rays. The conditions for outflow through the opercular slits after valve opening are discussed. 
9. The effect of leakage through the opercular valves and of inflow through notched mouth angles on the water velocities in the frontal mouth opening are presented. Morphological adaptations in these area's can be treated in their quantitative effect on flow velocity.

10. The internal form of the buccal cavity, the form of the promontory consisting of urohyal, sternohyoid muscle and pectoral girdle and the shape of the gills are explained as adaptations to a flow with only gradual changes in the direction of water accelerations.

11. A series of feeding types is distinguished based on the relative contributions of suction and forward motion with the time of valve opening as a third characteristic. Suction causes a flow to the mouth from all sides whereas swimming leads to a highly directed parallel flow.

12. Jaw protrusion greatly increases the flow velocity in the moving frame and has therefore similar effects as swimming to the prey. Due to protrusion the impulse added to the water can be kept at a low value. Protrusion besides increases the ecological versatility because it provides a highly directed suction flow in a habitat with e.g. many obstacles which prohibit fast swimming.

13. The accurate prediction of pressure changes in model studies is limited as pressures are proportional to the second derivatives of motion. Suction as well as forward motion contribute to pressure variations. Pressures and velocities calculated by simulating head length increase in the model demonstrate load increase during "growth" and suggest limits to which head structures are subjected. Combination of thus influenced factors suggest a restricted range of possible options.

14. Careful application of the above findings to existing schemes of the succession of types in the evolution of head construction in actinopterygian fishes strongly suggests that changes in jaw apparatus and opercular- and branchiostegal system improve the result of suction feeding and not only biting. 


\section{REFERENCES}

Alexander, R. McN. 1967a. Functional design in fishes. London; Hutchinson.

Alexander, R. McN, 1967b. The functions and mechanisms of the protrusible jaws of some acanthopterygian fish. J. Zool. Lond. 151, pp. 43-64.

Alexander, R. McN. 1969. Mechanics of the feeding action of a cyprinid fish. J. Zool. Lond. 159, pp. 1-15.

Alexander, R. McN. 1970. Mechanics of the feeding action of various teleost fishes. J. Zool. Lond. 162, pp. 145-156.

Ballintijn, C. M. 1968. The respiratory pumping mechanism of the carp Cyprinus carpio ( $L$ ). Thesis. Rijksuniversiteit Groningen, The Netherlands. 98 pp.

Barel C. D. N. 1980. Vergelijkend biologisch onderzoek aan cichliden. (In Dutch). Vakbl. Biol. 12, 60. pp. 228-239.

Blaxter, J. H. S. 1963. The feeding of herring larvae and their ecology in relation to feeding. Cal. Coop. Ocean. Fish. Invest., 10. pp.79-88.

Casinos, A. 1973. El mecanisme de deglució de l'aliment a Gadus callarias, Linnaeus 1758 (Dades preliminars). Bull. de la Soc. Catalana de Biologia, I (1), pp.43-52.

Casinos, A. 1974. Registres de la chute de pression de la cavité buccale chez quelque Gadiformes de nos côtes. XXIV-e Congr. Ass.-Plen. de Monaco, pp. 1-4.

Dullemeyer, P. 1974. Concepts and approaches in animal morphology. V. Gorkum, Assen, the Netherlands.

Elshoud-Oldenhave, M. J. W. 1979. Prey Capture in the Pike-Perch, Stizostedion lucioperca (Teleostei, Percidae): A Structural and Functional Analysis. Zoomorphology 93, pp. 1-32.

EJshoud-Oldenhave, M. J. W. and Osse, J. W. M. 1976. Functional morphology of the feeding -system of the Ruff, Gymnocephalus cernua (L. 1758)-(Teleostei, Percidae). J. Morph. Vol. 150, no. 2, pp. 399-422.

Fricke, H. W. 1973. Korallenmeer. pp. 177, 183. Belser Verlag, Stuttgart, 224 pp.

Gabe, I. T. 1972. Pressure measurement in experimental physiology. In: Cardiovascular Fluid Dynamics (ed. D.H. Bergel). Acad. press, London.

Greenwood, P. H. et al. 1966. Phyletic studies of teleostean fishes with a provisional classification of living forms. Bull. Am. Mus. Nat. Hist. 131/4 pp. 341-444.

Hertel, H. 1966. Structure-Form-Movement. pp. 124-140. Reinhold Publishing Corp, New York.

Hoff, N. J. 1967. Dynamic stability of structures. In: G. Herrmann: Dyn. stab. of struct. (proc.). Pergamon Press, Oxford. 313 pp.

Holeton, G, F. and Jones, D. R. 1975. Water flow dynamics in the respiratory tract of the carp (Cyprinus carpio L.). J. Exp. Biol. 63: pp. 537-549.

Ingen-Schenau, G. J. van 1981. A power balance applied to speed skating. Thesis. Vrije Universiteit, Amsterdam. The Netherlands. $126 \mathrm{pp}$.

Kayser, H. 1961. Der Bau und die Funktion des Kiefer- und Kiemenapparates von Knochenfischen der Gattungen Ammodytes und Callionymus. Zool. Beiträge. Neue Folge. Band 7. Drittes Heft. pp. 321-445. Duncker \& Humblot. Berlin.

Koning, C. and Taub, J. 1933. Stossartige knickbeanspruchung schlanker Stäbe im elastischen Bereich bei beiderseits gelankiger Lagerung. Luftfahrtforschung 10,17.

Koster, A. W. J. 1976. Interpolatie en approximatie mbv. Spline-functions. Enkele numerieke procedures. (in Dutch). Int. Rep. S105. Delft Hydraulics Laboratory, the Netherlands.

Lanshammar, H. 1982. On practical evaluation of differentiation techniques for human gait analysis. J. Biomechanics Vol. 15, No. 2, pp. 99-105.

Lauder, G. V. 1979. Feeding mechanics in primitive teleosts and in the halecomorph fish Amia calva. J. Zool. Lond. 187, pp. 543-578.

Lauder, G. V. 1980a. Hydrodynamics of prey capture by teleost fishes. Proceedings of the second Conference on Bio-Fluid Mech., Vol 2, pp.161-181. Plenum Press, New York.

Lauder, G. V. 1980b. The suction feeding mechanism in sunfishes (Lepomis): an experimental analysis. J. Exp. Biol. 88, pp. 49-72. 
Lauder, G. V. 1980c. Evolution of the feeding mechanism in primitive actinopterygian fishes: A functional anatomical analysis of Polypterus, Lepisosteus and Amia. J. of Morph. 163: pp. 283-317.

Lauder, G. V. and Liem, K. F. 1981. Prey capture by Luciocephalus pulcher: implications for models of jaw protrusion in teleost fishes. Env. Biol. Fish. Vol. 6, No. 3/4, pp. 257-268.

Leeuwen, J. L. van in prep. The relation between swimming and suction in the feeding mechanism of the rainbow trout; with general considerations for the actinopterygian system.

Leeuwen, J. L. van and Muller, M. in prep. The recording and interpretation of pressures in prey sucking fish.

Lessertisseur, J. et Robineau, D. 1969. Le mode de l'alimentation des premiers vertébrés et l'origine des mâchoires. Bull. du Mus. Nation. d'Hist. Natur. 2-e Série. Tome 41, No 6, pp. 1321-1347. Tome 42, No 1, pp. 102-121.

McAllister, D. E. 1968. The evolution of branchiostegals and the classification of teleostome fishes. Bull. Nation. Mus. of Canada 221, I-XIV: pp. 1-239.

McCutchen $\mathrm{Ch}$. W. 1977. Froude propulsive efficiency of a small fish, measured by wake visualization. From: Scale effects in animal locomotion. Acad. Press, London. pp. 339-363.

Merzkirch, W. 1974. Flow visualisation. Acad. Press, New York.

Milne-Thomson, L. M. 1968. Theoretical hydrodynamics, 5th edition, MacMillan Ltd., London.

Moy-Thomas, R. A. and Miles, R. S. 1971. Palaeozoic fishes. Ch. 4: Subclass Acanthodii. London. Chapman and Hall; Philadelphia: Saunders. 259 pp.

Muller, M. and Osse, J. W. M. 1978. Structural adaptations to suction feeding in fïsh. Proc. Zodiacsymp. "On Adaptation", pp. 57-60, Pudoc, Wageningen.

Muller, M., Osse, J. W. M. and Verhagen, J. H. G. 1982. A quantitative hydrodynamical model of suction feeding in fish. J. Theor. Biol., Vol. 95, no. 1, pp. 49-79.

Nelson, J. S. 1976. Fishes of the world. John Wiley \& Sons, New York, London. 416 pp.

Nyberg, D. W. 1971. Prey Capture in the Largemouth Bass. The Am. Midl. Naturalist, 86 (1), pp. 128-144.

O'Connell, C. P. 1972. The interrelation of biting and filtering in the feeding activity of the northern anchovy (Engraulis mordax). J. Fish. Res. Bd. Can. 29, pp. 285-293.

Osse, J. W. M. 1969. Functional Morphology of the head of the Perch (Perca fluviatilis L.): An electromyographic study. Neth. J. of Zool. 19 (3) pp. 289-392.

Osse, J. W. M. 1973. Form and function of the branchiostegal apparatus in Amia calva. Neth. J. of Zool. 23 (3): pp. 359,360.

Osse, J. W. M. 1976. Mécanismes de la respiration et de la prise des proies chez Amia calva Linnaeus. (abstract). Rev. Trav. Inst. Pêches Marit. 40 (3 et 4): pp.701,702.

Osse, J. W. M. and Muller, M. 1980. A model of suction feeding in teleostean fishes with some implications for ventilation. In Environmental physiology of fishes. M.A. Ali, edit. NATO-ASI. Series A. Life Sciences.

Schaeffer, B. and Rosen, D. E. 1961. Major adaptive levels in the evolution of the actinopterygian feeding mechanism. Am. Zoologist 1, pp. 187-204.

Taub, J. 1933. Stossartige knickbeanspruchung schlanker Stäbe im Elastischen Bereich. Luftfahrtforschung 10,65 .

Thompson, D. H. 1972. A survey of water tunnel flow visualization techniques. Aerodynamics Note 355. Dept. of supply Austr. Def. Scient. Serv.; Aeron. Res. Lab. pp.1-18.

Verhagen, J. H. G. 1967. The Impact of a Flat Plate on a Water Surface. J. of Ship Research, Dec., pp. 211-223

Webb, P. W. 1975. Acceleration performance of rainbow trout Salmo gairdneri and green sunfish Lepomis cyanellus. J. Exp. Biol. 63, pp. 451-465.

Webb, P. W. 1976. The effect of size on the fast-start performance of rainbow trout Salmo gairdneri, and a consideration of piscivorous predator-prey interactions. J. Exp. Biol. 65, pp.157-177.

Weihs, D. 1980. Hydrodynamics of suction feeding of fish in motion. J. Fish Biol. 16, pp. 425-433. 
APPENDIX I: Formulas.

(1) Thickness of boundary layer: $\delta=\sqrt{v T}$

(2) Condition for fish head dimensions: $H^{2}<<L^{2}$

If this condition is satisfied the model may be applied.

(3) Profile form (cylinder and cone):

$$
\begin{array}{ll}
h(x, t)=\frac{\mathrm{h}_{1}(t) \cdot x+h_{2}(t) \cdot(l-x)}{l} & x \in[0, l] \\
h_{1}, h_{2}>0 & , \quad h^{2}<<l^{2} \\
A(x, t)=\pi \cdot h^{2}(x, t) &
\end{array}
$$

(4) Profile movement (cylinder and cone):

$$
\begin{array}{r}
h_{*}(t)=h_{* n u l}+\Delta h_{* \max } \cdot\left[\frac{\left(t-t_{v *}\right)}{\left(t_{h_{*} \max }-t_{v *}\right)} \cdot \exp \left\{1-\frac{\left(t-t_{v^{*}}\right)}{\left(t_{h * \max }-t_{v *}\right)}\right\}\right]^{\alpha^{*}} \\
h_{*}(t)=h_{* n u l} \quad\left(t \leq t_{v *}\right) \\
\quad\left(t>t_{v *}\right) \\
*=1 \text { or } 2
\end{array}
$$

(5) Profile movement (cylinder):

$$
h(t)=h_{n u l}+\left(h_{\max }-h_{n u l}\right) \cdot\left[\frac{t}{t_{h_{\max }}} \cdot \exp \left\{1-\frac{t}{t_{h_{\max }}}\right\}\right]^{\alpha}
$$

(6) Water velocity (cylinder and cone) with closed valve in moving frame:

$$
u_{v}(x, t)=-\frac{1}{A} \int_{0}^{x} \frac{\partial A}{\partial t} d x \quad(t \leq \tau)
$$

(7) Water velocity (cylinder) with closed valve in moving frame:

$$
u_{v}(x, t)=-\frac{A^{\prime}}{A} x \quad(t \leq \tau)
$$

(8) Water velocity (cylinder or cone) with open valve in moving frame:

$$
u_{n}(x, t)=u_{v}(x, t)+\frac{u_{n}(0, t) \cdot A(0, t)}{A(x, t)} \quad(t>\tau)
$$

(9) Velocity of water along the axis in front of the mouth aperture (in earthbound frame):

$$
u=\frac{u_{m} h_{1}{ }^{3}}{\sqrt{\left\{\left(x-x_{m}\right)^{2}+h_{1}{ }^{2}\right\}^{3}}}
$$

(10) Relation between height of fish and diameter of mouth aperture:

$$
\frac{r_{\text {asymptote }}}{h_{1 \text { effective }}}=\sqrt{(a+1)} \quad(a \geq 0)
$$

(a may be replaced by $|b|)$.

(11) Relation between velocities in earth-bound frame and moving frame:

$$
u_{1}=u(l, t)=u_{m}-U
$$


(12) Relation between suction, swimming and translation:

$$
u_{m}=-a . U+S=b . U \quad(a \geq 0)
$$

(13) Relation between $u_{1}, u_{m}, U$ and $a$ :

$$
u_{1}=-(a+1) \cdot U=\frac{(a+1)}{a} \cdot u_{m} \quad(a \geq 0)
$$

(a may be replaced by $|b|$ ).

(14) Pressure inside the translating profile:

$$
\begin{aligned}
\frac{\Delta p_{v}(x, t)}{\rho}=\frac{\left(p-p_{0}\right)}{\rho}= & \int_{x}^{l}\left[\frac{\partial u_{v}}{\partial t}+u_{v} \frac{\partial u_{v}}{\partial x}\right] \mathrm{d} x \\
& \text { "internal pressure" } \\
& +\frac{u_{1}^{\prime}}{(a+1)}(x-l)+\frac{u_{1}}{(a+1)}\left(u_{v}-u_{1}\right) ! \\
& +\frac{1}{2}\left[\frac{1}{(a+1)^{2}}-1\right] u_{1}^{2}+\frac{a}{(a+1)}\left(u_{1} h_{1}\right)^{\prime} .
\end{aligned}
$$

APPENDIX II: Nomenclature.

$A \quad$ Area of transverse section of profile.

$a \quad$ Ratio between $u_{m}$ and $U$ with suction only.

$b \quad$ Idem, including both suction and swimming.

$h \quad$ Profile radius.

$h_{1} \quad$ Profile radius at mouth aperture.

$h_{2} \quad$ Profile radius at opercular region.

$h_{* \max }$ Maximal value of profile radius. $\quad *=1$ or 2

$h^{*}$ nut $\quad$ Minimal value of profile radius. $\quad *=1$ or 2

$H \quad$ Dimension of profile radius.

$l \quad$ Length of profile.

$L \quad$ Dimension of profile length.

$n \quad$ Number of animals (Fig. 1),

$p, P \quad$ Pressure.

$p_{0} \quad$ Hydrostatic pressure.

$p_{m} \quad$ Pressure in mouth aperture.

$r \quad$ Coordinate of radius (cylindrical coordinates).

$r_{1} \quad$ Horizontal radius of mouth aperture.

$r_{2} \quad$ Vertical radius of mouth aperture.

$S \quad$ Swimming velocity.

$t \quad$ Time. 


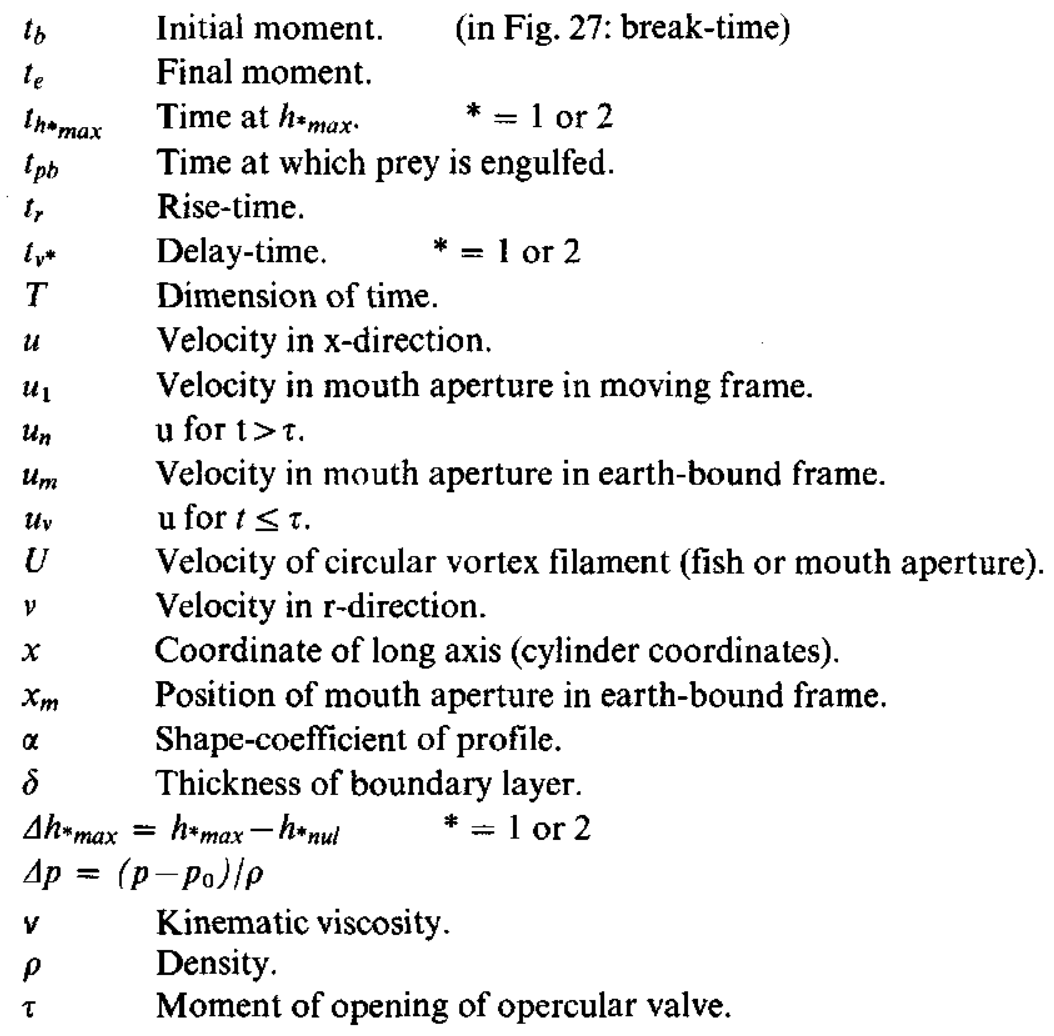


HOOFDSTUK 3

A Quantitative Hydrodynamical Model of Suction Feeding in Fish 


\title{
A Quantitative Hydrodynamical Model of Suction Feeding in Fish
}

\author{
M. Muller, J. W. M. Osse and J. H. G. Verhagen
}

Department of Experimental Animal Morphology and Cell Biology, Agricultural University, Zodiac Marijkeweg 40, 6709 PG

Wageningen, The Netherlands

(Received 6 April 1981, and in revised form 10 September 1981)

The model consists of an expanding and compressing rotational symmetric profile with prescribed movement. A posterior valve will open according to chosen boundary conditions. All calculations are based on unsteady flow as this is an essential feature of prey-sucking in e.g. $50 \mathrm{msec}$. Calculations prove that the effect of friction is negligible in typical suction acts. Movements of the profile were given in accordance with actual movement data. Experimental data from transducer measurements (pressure and velocity) of prey-sucking fish were used to test the model throughout its construction.

The external flow to the "mouth" and the translation of the profile caused by suction are modelled by combining a parallel stream with a circular vortex filament at the lips of the fish. Equations to calculate velocities and pressures, before and after opening of the posterior valve are given. The model provides evidence for a narrow range of possible combinations of size and movement characteristics, indicating possible restrictions in head construction of fish.

\section{Introduction}

The description of water flow in and about the mouth of a fish, sucking its prey, may give insight in the physical demands to which the construction of the fish head is subjected. It may also open a way to explain the evolution of the fish's sucking system and by this to gain insight in the enormous variety of fish head forms.

Till now, all authors, which described hydrodynamical processes during prey suction in fishes, presented their description using steady flow equations or drew conclusions from such flow (Alexander, 1967a, $b$; Osse, 1969; Elshoud-Oldenhave \& Osse, 1976; Lauder, 1980a, b; Pietsch, 1978; Weihs, 1980). However, a prey sucking fish expands its head in a very short time, e.g. in a lionfish (Pterois) $30-50 \mathrm{msec}$ and the prey is swallowed within $20 \mathrm{msec}$ with a velocity up to $10 \mathrm{~m} / \mathrm{sec}$. Therefore, the flow is highly unsteady and any hydrodynamic conclusions as to general mechanisms 
involved based on a steady flow picture are invalid. That the consequences of the unsteady character of the flow during prey suction are not drawn is apparent from (Lauder, 1980a). In his review on hydrodynamics of fish feeding he strongly suggests that there exists "inertial feeding" in fishes and derives evidence for this view by deducing the water velocities from the measured pressure differences in successive time intervals. First, inertial feeding according to Gans (1969) presupposes a fixed position of the prey with only moving the fish's head. This does occur in air but not generally in water. Second, the application of steady flow considerations is in contradiction with the concept inertial feeding. If pressure alterations during feeding are translated in changing velocities without due consideration to positive or negative accelerations, the derived velocities suggest a rapidly changing flow direction inside the fish's mouth within a few milliseconds. For such a flow to occur in reality enormous accelerations and thus forces (pressures) must be present. This time splitting of the events during feeding in phases without attention for the process of mouth enlargement and water flow as a whole results in invalid conclusions.

The essence of the procedure followed in our model is to derive the velocities of the water inside the mouth from the expanding and compressing profile of the fish's head, from velocities due to the forward motion of the profile as a whole through the water and from considerations of the flow in front of the fish's head. The pressures are then calculated from these velocities and the accelerations occurring (Muller \& Osse, 1978). In this paper the mathematics of the hydrodynamical model of unsteady flow will be presented. The biological background, the experimental verification and the conclusions drawn from the model are discussed elsewhere (Muller \& Osse, in preparation).

\section{Materials and Methods}

The equation of continuity and the equation of motion for water flow were solved in and around a rotational symmetric profile. Because of the complexity of the equations a FORTRAN-program of the model was made. The program was run on the DEC-10 system of the Agricultural University, Wageningen.

Both mathematical and numerical analysis were supported through helpful advises of the Delft Hydraulics Laboratory.

Radial movements of the profile were defined as analogues of measured suction movements of several fish species. The movement data were obtained from 400 frames/sec films of sucking fish.

To verify the calculated water velocities and pressures, measurements of these quantities were carried out during suction movements of free 
swimming fish, using miniature pressure and velocity transducers, which could be placed in adequate positions within the fish's mouth.

\section{Short Description of the Feeding Process (Fig. 1)}

To give some idea about a characteristic feeding process in fish, a short description of feeding in the lionfish (Pterois) is given. At the time $t=0$ the fish has approached the prey as close as possible and is almost at rest (Fig. 1(a)). Now the fish opens and protrudes its mouth, coupled with a slight adduction of suspensoria and opercula. The mouth aperture and buccal cavity become almost rotational symmetric. A minor amount of water is sucked in (Fig. 1(b)).

Next, the fish starts to suck by abduction of suspensoria and opercula, by depression of the mouth-bottom and elevation of the neurocranium. The prey is sucked in (not necessarily in this phase of the movement) and the branchiostegal membrane fans out between hyoid and pectoral girdle, initially forming a closed valve (Fig. 1(c,d,e)).

At a certain moment the branchiostegal valves open and water leaves the opercular slits (Fig. 1(f)). The opercula continue their outward movement even when the mouth is already closed (Fig. 1(g)). Finally, the opercula are adducted and the mouth is closed with still protruded premaxillaries (Fig. 1(h)).

During the suction process the fish sucks itself forward. Propulsive movements of body and tail may support this motion. Observations from films taken from other fish species (Amia, Entelurus, Gadus, Platichthys, Salmo, Spinachia, Taurulus, Stizostedion, Syngnathus and Perca) provide solid evidence for the view that the above process is in fact a general phenomenon in fishes.

\section{Hydrodynamics; Simplifying Approximations}

Before proceeding to modelling development let us consider some simplifying assumptions which can be adopted for the treatment of the hydrodynamical processes and calculations.

We searched for ways to reduce the complexity of the calculations maintaining however all the essentials of the suction process.

The following approximations fulfil these requirements and arguments for the validity of applying them are presented:

(1) friction has to be neglected;

(2) rotational symmetry of the sucking structures is demanded;

(3) the prey needs to behave as an element of the sucked fluid. 
(A)

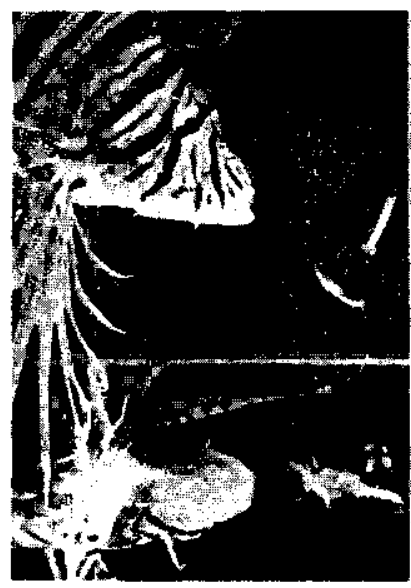

$\left(\begin{array}{l}\text { Q } \\ c \\ 0\end{array}\right) \quad 10$

20 (E)

25
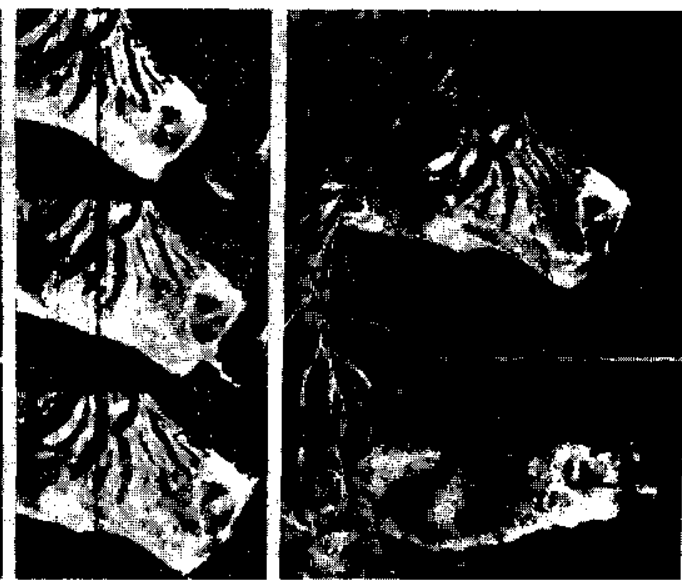

(F)

$32.5(G)$

$42.5(\mathrm{H})$

$62 \cdot 5$
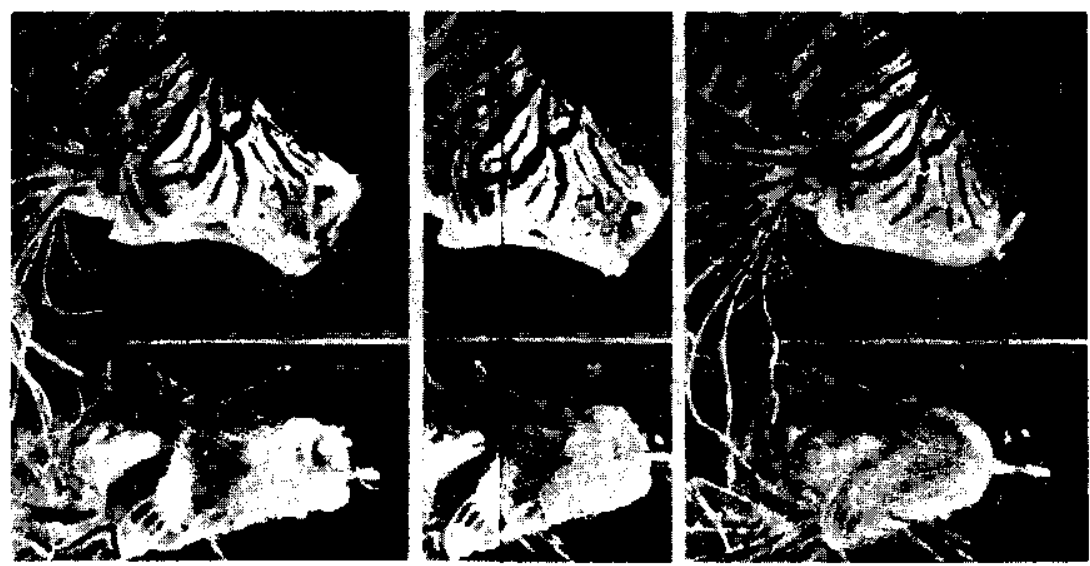

Fig. 1. Stages of the suction process in Pterois russelli (Bennett). The photographs are taken from $400 \mathrm{fr} / \mathrm{sec}$ film (exposure time $4000^{-1} \mathrm{sec}$ ). Both a ventral and a lateral view are given except in $\mathrm{B}, \mathrm{C}$ and $\mathrm{D}$. The dots in the pictures represent polystyrene spheres with density close to sea water density which provide accurate fiow visualisation. The numbers indicate the time in milliseconds from $\mathbf{A}: \boldsymbol{f}=0$. A: start position, $B, C$ and $D$ : suction, $E$ : maximum expansion of the head with cksed opercular and branchiostegal valves, $F$ : valves opened, G: maximum expansion of the head with open valves, $\mathrm{H}$ : mouth closed and protruded, valves still open. 
From the following it will be apparent that the short duration of the suction movement allows the first simplification.

When fluid flows through a tube, a boundary layer is built up (Fig. 2). In the boundary layer the velocity of the water varies between $u=0$ near the wall of the tube to $u=u$ towards its centre. In the central part of the tube potential (frictionless) flow with $u=u$ exists.

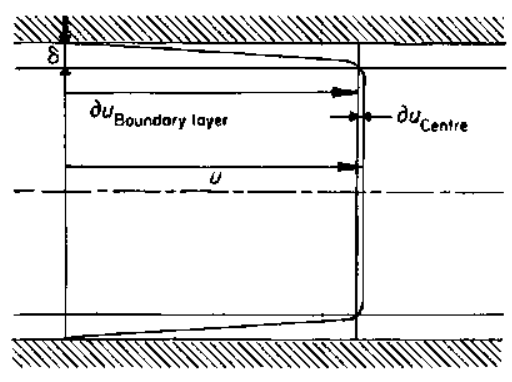

Fig. 2. Velocity profile of the flow in the fish's mouth tube. The dimension of the boundary layer is exaggerated. Explanation in text.

The Navier-Stokes equation in the $x$ direction is in cylindrical coordinates (Milne-Thomson, 1968)†:

$$
\frac{\partial u}{\partial t}+u \frac{\partial u}{\partial x}+v \frac{\partial u}{\partial r}=-\frac{1}{\rho} \frac{\partial p}{\partial x}+\nu\left(\frac{1}{r} \frac{\partial u}{\partial r}+\frac{\partial^{2} u}{\partial r^{2}}+\frac{\partial^{2} u}{\partial x^{2}}\right)
$$

in which $u$ is velocity in $x$ direction, $x$ co-ordinate of long axis of profile, $v$ radial flow velocity, $r$ co-ordinate of radius, $\rho$ density of water, $p$ pressure and $\nu$ kinematic viscosity.

For the suction process the following characteristic dimensions may be given.

\section{TABLE 1}

\begin{tabular}{ccc}
\hline Parameter & Dimension & Approximate value \\
\hline$x$ & $L$ & $6.0 \times 10^{-2} \mathrm{~m}$ \\
$r$ & $H$ & $2 \cdot 0 \times 10^{-2} \mathrm{~m}$ \\
$t$ & $T$ & $6.0 \times 10^{-2} \mathrm{sec}$ \\
$r$ (bound. layer) & $\delta$ & \\
\hline
\end{tabular}

† For symbols see Nomenclature. 
Furthermore is:

TABLE 2

$$
\begin{aligned}
& \nu \approx 10^{-5} \mathrm{~m}^{2} / \mathrm{sec} . \\
& \rho \approx 10^{3} \mathrm{~kg} / \mathrm{m}^{3}
\end{aligned}
$$

Inside the boundary layer friction plays an important role. The dimension of $\partial u / \partial r$ is there $L / \delta T$ and of $\partial^{2} u / \partial r^{2}: L / \delta^{2} T$. The dimension of $\partial p$ is $\rho\left(L^{2} / T^{2}\right)$ and the dimension of $v=\delta / T$. Note that here the velocities are considered with respect to the wall.

Inside the boundary layer the orders of magnitude of the subsequent terms in the Navier-Stokes equation (1) are compared by substitution of the characteristic dimensions in it:

$$
\frac{L}{T} \cdot \frac{1}{T}+\frac{L}{T} \cdot \frac{L}{T} \cdot \frac{1}{L}+\frac{\delta}{T} \cdot \frac{L}{\delta T}=-\frac{1}{\rho} \cdot \rho \frac{L^{2}}{T^{2}} \cdot \frac{1}{L}+\nu\left(\frac{1}{\delta} \cdot \frac{L}{\delta T}+\frac{L}{\delta^{2} T}+\frac{L}{T} \cdot \frac{1}{L^{2}}\right)
$$

or

$$
1+1+1=-1+\nu\left(\frac{T}{\delta^{2}}+\frac{T}{\delta^{2}}+\frac{T}{L^{2}}\right) .
$$

(Note that the numbers 1 in formulas (2) and (3) designate an order 1 of magnitude.)

Because it was stated that in the boundary layer friction is of importance, the underlined term in formula (2) must be of order 1.

Therefore:

$$
1=\frac{\nu T}{\delta^{2}}\left(1+1+\frac{\delta^{2}}{L^{2}}\right)
$$

Because $L / \delta \gg 1$, equation (3) reduces to:

$$
\delta=\sqrt{\nu T} \text {. }
$$

Substituting the characteristic values results in $\delta$ is $0.8 \mathrm{~mm}$. The thickness of the boundary layer may therefore be neglected, which implies the validity of calculations with neglection of friction. Even with a movement taking $200 \mathrm{msec}$ this procedure is justified.

It must be noted however that the above discussion presupposes that the fluid is at rest at $t=0$. Under these conditions a frictionless inflow in the mouth aperture will occur. The equations without friction are therefore only applicable to situations where suction movements follow a chase of the prey when the dimensions of the boundary layer are small compared to the dimensions of the head of the predator. 
Outside the boundary layer (in the centre of the tube) friction is of no importance. The Navier-Stokes equation without the friction term still has the term $v \partial u / \partial r$. To simplify later calculations an estimation of the dimension of $v \partial u / \partial r$ is necessary. We now proceed to consider the velocities with respect to the axis of the mouth tube. As $\partial u$ cannot be scaled in the $x$ direction it must be judged from velocity differences in the $r$ direction. To rotationfree flow applies (Milne-Thomson, 1968):

$$
\frac{\partial u}{\partial r}=\frac{\partial v}{\partial x} .
$$

The dimension of $v \partial u / \partial r$ is therefore $H^{2} / T^{2} L$. The terms $\partial u / \partial t$ and $u \partial u / \partial x$ may both be scaled by $L / T^{2}$.

The term $v \partial u / \partial r$ can only be neglected if $H^{2} / T^{2} L \ll L / T^{2}$ and therefore:

$$
H^{2} \ll L^{2} .
$$

It is apparent that in most fishes the shape of the mouth tube agrees with this condition.

Thus the Navier-Stokes equation can be reduced to:

$$
\frac{\partial u}{\partial t}+u \frac{\partial u}{\partial x}=-\frac{1}{\rho} \frac{\partial p}{\partial x},
$$

as long as the characteristic values considered in the above discussion on the role of friction are not in any important measure exceeded. In this form (equation (7)) the equation of motion will be applied to calculate the pressures in and near the profile.

The validity of the other two simplifying approximations, mentioned above appeared to be valid because of biological arguments (Muller \& Osse, in preparation). Here it will be sufficient to state that observations from high-speed movies of more than ten species of fish with among them highly asymmetrical flatfishes shows convincingly that a rotational symmetry of the sucking structures is rapidly obtained after the start of feeding. The last approximation viz. that the prey behaves as an element of the sucked water is in agreement with our observations and can be expected because the densities of prey and water correspond closely.

In view of the high flow velocities and low pressures measured the phenomenon of cavitation needs consideration. Not only has this phenomenon never been observed in the numerous experiments $(\approx 200)$ we carried out, it is also improbable to occur on theoretical considerations.

To determine the condition under which cavitation phenomena may occur an estimation of maximal negative pressures is required. These largest negative pressure peaks with respect to the environmental pressure are 
found in the highly unsteady beginning of the suction process. Then equation (7) may be written as:

$$
-\frac{1}{\rho} \frac{\partial p}{\partial x}=\frac{\partial u}{\partial t}
$$

Taking the following rather extreme values:

TABLE 3

$\begin{aligned} \Delta u & \approx 20 \mathrm{~m} / \mathrm{sec} \\ \Delta t & \approx 20 \mathrm{msec} \\ \Delta x & \approx 0.1 \mathrm{~m} \\ \rho & \approx 10^{3} \mathrm{~kg} / \mathrm{m}^{3}\end{aligned}$

we obtain for $\Delta p$

$$
\Delta p \approx-10^{5} \mathrm{~N} / \mathrm{m}^{2} \approx-1 \mathrm{~atm} .
$$

During $20 \mathrm{msec}$ the pressure in the buccal and opercular cavities will be close to $0 \mathrm{~atm}$. Therefore it seems to be improbable that the water will break and cavitation occurs.

A similar conclusion will result if equation (7) as a whole is considered.

\section{The Model}

\section{(A) OUTLINES OF THE PROCEDURE}

Within the above discussed limits, the equation of continuity and the equation of motion are solved for a given rotational symmetric profile $h(x, t)$ of length $l$ with dictated movements.

Actually we choose first a cylindrical and later a conical profile form. The cylinder provides a relatively simple analytical solution of water velocities and pressures (see Appendix), while in the case of the cone a more complex but also a realistic movement can be simulated. As it is however impossible to give a simple analytical solution for the cone model computer-simulation was applied.

At one end of the profile $(x=0)$ a valve ("opercular and branchiostegal valve") has been constructed, which opens at a moment $t=\tau$, depending on different boundary conditions (derived from pressure or velocity). As a result of the flow, generated by the radial movements, the profile will also be sucked forward along its axis. 
The combination of the forward suction of the profile and the inflowing water results in a flow in front of the "mouth aperture" $(x>l)$. From this flow the pressure in the mouth aperture $(x=l)$ was calculated, thus providing a boundary condition for the calculation of the pressures inside the profile.

After opening of the opercular valve $(t>\tau)$ also a field of flow had to be defined "behind" the moving profile $(x<0)$. Considering that here flow through an aperture occurs, we constructed a field of a parallel stream, bound by an approximately cylindrical free streamline sheet.

(B) PROFILE FORM AND PROFILE MOVEMENT

The profile form (Fig. 3), cylinder or cone, may be defined as:

$h(x, t)=\frac{h_{1}(t) . x+h_{2}(t) .(l-x)}{l} \quad x \in[0, l], \quad h^{2} \ll l^{2}, \quad h_{1}, h_{2}>0, \quad t \geq 0$

in which $h_{1}$ is the profile radius at the mouth aperture, $h_{2}$ the profile radius at the opercular valve and $l$ the profile length.

$$
A(x, t)=\pi \cdot h^{2}(x, t)
$$

where $A$ is the area of transverse section of profile.

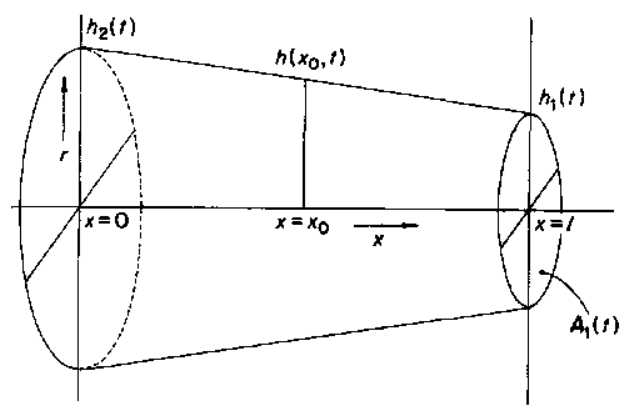

FIG. 3. Model of fish head. This profile is expanded and compressed during suction. At $x=0$ the opercular and branchiostegal valve is localized, at $x=l$ the mouth aperture. The graphs in Fig. 4 describe profile movements. Further explanation in text.

For $h_{1} \neq h_{2}$ one gets a conical profile, for $h_{1}=h_{2}$ a cylindrical one.

The profile movement (Fig. 4) is defined as an expansion, followed by a compression of the profile. A function which describes such a movement 


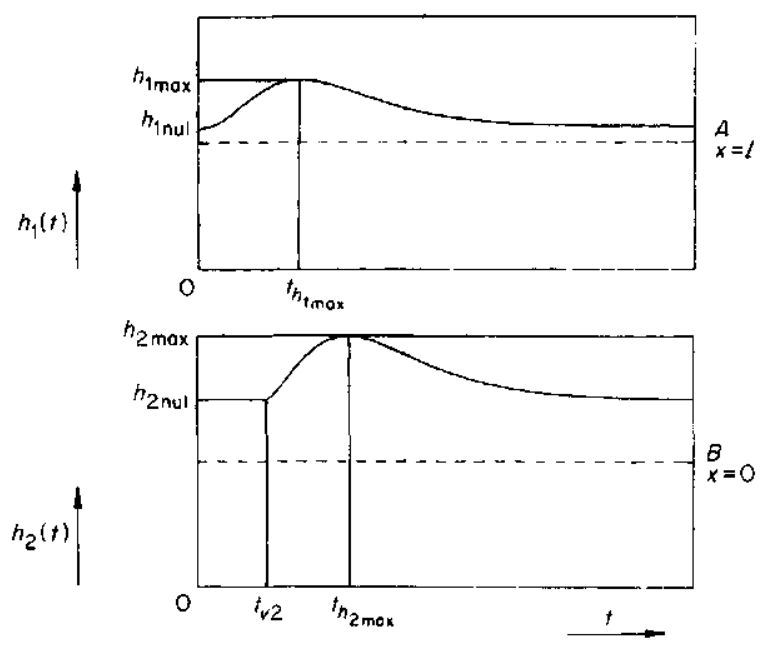

FIG. 4. Profile movements. A: movement of mouth aperture, B: movement of opercula.

has been chosen as follows:

$$
\begin{gathered}
h_{*}(t)=h_{*_{\mathrm{nul}}}+\Delta h_{*_{\max }} \cdot\left[\frac{\left(t-t_{v^{*}}\right)}{\left(t_{h_{\text {max }}}-t_{v^{*}}\right)} \cdot \exp \left\{1-\frac{\left(t-t_{v^{*}}\right)}{\left(t_{h^{*} \max }-t_{v^{*}}\right)}\right\}\right]^{\alpha^{*}} \\
\left(t>t_{v^{*}}\right) \\
h_{*}(t)=h_{* \text { nul }} \quad\left(t \leq t_{v^{*}}\right)
\end{gathered}
$$

where $\Delta h_{*_{\max }}=\left(h_{*_{\max }}-h_{*_{\text {mal }}}\right)$ and:

$$
\begin{gathered}
t, t_{v^{*}} \geq 0, \quad t_{h_{\text {max }}}>t_{v^{*}}, \quad h_{*_{\text {nul }}}>0 \\
h_{*_{\max }}>h_{*_{\text {nul }}}, \quad \alpha^{*} \geq 0
\end{gathered}
$$

where $h_{*_{\text {nul }}}$ is minimal value of profile radius, $h_{*_{\max }}$ maximal value of profile radius, $t_{v^{*}}$ the delay time between expansion of $h_{1}$ and $h_{2}$ and $\alpha$ the expansion coefficient of the profile.

The index $*$ from the parameters in the equations (11) and (12) may be 1 to define the movement at $x=l$ (mouth aperture) or designate a 2 to obtain the movement at $x=0$ (opercular region).

Formulas (11) and (12) give a description of the dictated profile movement. Most of the measured fish head movements could be fitted with this function. 
(C) VELOCITIES

(a) Velocities inside the profile

The velocities of the streaming fluid are obtained from the equation of continuity in cylindrical co-ordinates (Milne-Thomson, 1968):

$$
\frac{\partial u}{\partial x}+\frac{1}{r} \frac{\partial(v r)}{\partial r}=0
$$

The streaming motion inside a profile with $h^{2} \ll l^{2}$ will be approximated by a parallel stream. Therefore $u$ will be constant in the $r$ direction and $\partial u / \partial x$ will also be independent of $r$. By integrating equation (13) with respect to $r$, we get:

$$
v=-\frac{1}{2} r \frac{\partial u}{\partial x}
$$

The radial velocity of the profile wall is:

$$
v=\frac{\mathrm{d} h}{\mathrm{~d} t}=\frac{\partial h}{\partial t}+u \frac{\partial h}{\partial x} .
$$

Substituting equation (15) in equation (14) and taking into account $h=$ $\sqrt{A / \pi}$ (see equation (10)) we find after some algebra for the equation of continuity:

$$
\frac{\partial A}{\partial t}+\frac{\partial(u A)}{\partial x}=0
$$

Integrating equation (16) to $x$, inside the profile, gives:

$$
u(x, t)=-\frac{1}{A} \int_{0}^{x} \frac{\partial A}{\partial t} \mathrm{~d} x+\frac{u(0, t) \cdot A(0, t)}{A(x, t)} .
$$

With closed opercular valve (for $t \leq \tau$ ) no water will flow through the opercular slits and therefore $u(0, t)=0$. Thus, we calculate the velocities inside the profile with opercular valve closed with the equation:

$$
u_{v}(x, t)=-\frac{1}{A} \int_{0}^{x} \frac{\partial A}{\partial t} \mathrm{~d} x \quad(t \leq \tau) .
$$

When the opercular valve is opened $(t>\tau)$, we get from equations (17) and (18):

$$
u_{n}(x, t)=u_{v}(x, t)+g(x, t) \quad(t>\tau)
$$


The function $g(x, t)$ is defined by:

$$
g(x, t)=\frac{u_{n}(0, t) \cdot A(0, t)}{A(x, t)} .
$$

In order to determine this function, the velocity of the water in the opercular slit $u_{n}(0, t)$ has to be defined. Section $\mathrm{D}$, pressures, explains the problems involved in deriving this velocity from the pressure at $x=0$. In order to obtain the required boundary condition $\left(u_{n}(0, t)\right)$ from the velocity at $x=l$ we stated that after opening of the opercular valve the fish (profile) is unable to continue the generation of an appreciable force for sucking itself forward. A flow of water entering the mouth is however maintained for some time after valve opening. Because of the lack of friction the profile will then continue to move forward with a constant velocity, resulting in a constant flow through the mouth aperture (see section D). As discussed previously (section 4) friction will become an important factor in the actual situation several hundreds of milliseconds after the start of the suction movement. This does not need further comment because we focus in the process of prey capture not on prey handling and swallowing. Other movements of the fish with fins, body or tail are not further commented here but discussed in Chapter 6 and Muller \& Osse (in preparation).

The boundary condition for the velocity becomes now:

$$
u_{n}(l, t)=u_{v}(l, \tau) \quad(t \geq \tau) .
$$

From equations (19)-(21) we obtain then for $g(x, t)$ :

$$
g(x, t)=\left[u_{v}(l, \tau)-u_{v}(l, t)\right] \frac{\boldsymbol{A}(l, t)}{\boldsymbol{A}(x, t)} .
$$

To avoid discontinuities in the pressure, the moment $t=\tau$ must be chosen at an extreme value of the velocity in the mouth aperture (see also 4). Other choices of $u_{n}$ for $t>\tau$ and of the moment $t=\tau$ are possible but lead to unnecessary complications.

(b) Velocities outside the profile (Fig. 5)

As the profile sucks itself forward in an earth-bound frame, a parallel stream will occur, relative to the frame of the profile.

At large distances the mouth aperture of the fish may be regarded as a sink (Fig. 5(a), see also Alexander, 1967a, b; Weihs, 1980). However in this case, the internal flow (a parallel stream) is hardly to couple with the external one (the sink) because of the acute angles in the streamlines, which will occur in the mouth aperture of the fish. A better approximation is obtained when the mouth aperture is regarded as a dipole (Fig. 5(b)). Both 


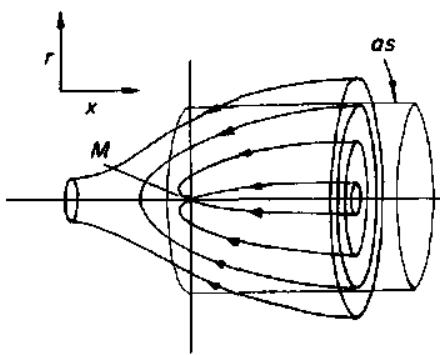

(A)

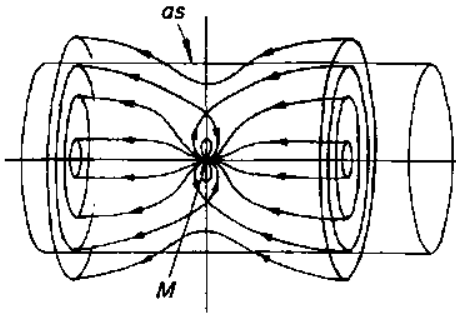

(B)

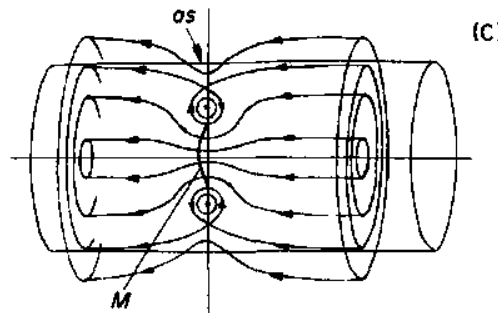

FIG. 5. Fields of flow in front of the mouth aperture, relative to the frame, moving with the fish. A: combination of sink and parallel stream, B: dipole and parallel stream, C: circular vortex filament and parallel stream. M: mouth aperture of fish, as: asymptote of dividing streamline. Note the positions of the singularities. Further explanation in text.

the sink and the dipole model explain accurately the observation that the fish aims at the prey (see p. 64 Osse \& Muller, 1980).

However, still the disadvantage remains that the singularity of the field of flow lies at the most important place of this field, i.e. in the mouth aperture. Therefore, we finally choose a circular vortex filament as an approximation of the mouth aperture. The singularities then lie outside the flow in the lips of the fish, and coupling between internal and external flow is excellent (Fig. 5(c) also see Muller \& Osse, 1978).

The stream function $\psi$ of a circular vortex filament is (Milne-Thomson, 1968):

$$
\psi=\frac{K r h_{1}}{4 \pi} \int_{0}^{2 \pi} \frac{\cos \omega \mathrm{d} \omega}{\sqrt{\left(x^{2}+h_{1}^{2}+r^{2}-2 h_{1} r \cos \omega\right)}}
$$




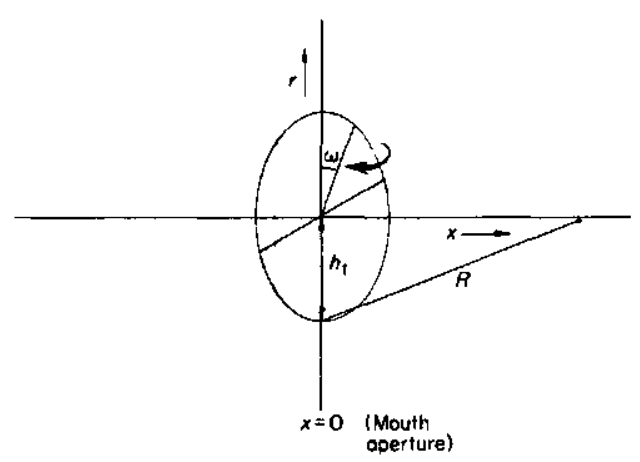

FIG. 6. A circular vortex filament with the parameters used in formula (23). Explanation in text.

where $K$ is the strength of the vortex and $\omega$ is the angle in cylindrical co-ordinates. Note the direction of the flow and that $x=0$ represents here the mouth aperture of the fish (Fig. 6). Near the $x$ axis, this expression is reduced to:

$$
\psi=\frac{K h_{1}^{2} r^{2}}{4 \sqrt{\left(x^{2}+h_{1}^{2}\right)^{3}}}
$$

The velocity in the $x$ direction becomes:

$$
u=-\frac{1}{r} \frac{\partial \psi}{\partial r}=\frac{-K h_{1}^{2}}{2 \sqrt{\left(x^{2}+h_{1}^{2}\right)^{3}}}
$$

which reduces for $x=0$ (mouth aperture of the fish) to $u_{m}$ :

$$
u_{m}=-\frac{K}{2 h_{1}} \text {. }
$$

The streamline of a fish is not only important during locomotion but also during suction. In the first case a minimum friction drag is important, in the second case a minimal pressure drag is favourable. The calculation of the dividing streamline, separating the flow into the mouth from the flow around the fish head gives the optimal ratio between mouth diameter and the overall height of the fish body. The stream function of the combination of a circular vortex filament and a parallel stream is presented in Fig. 7(a).

For large $x$ the circular vortex filament may be approximated by a dipole with strength $\mu$ :

$$
\mu=\frac{K h_{1}^{2}}{4} \text {. }
$$


(A)

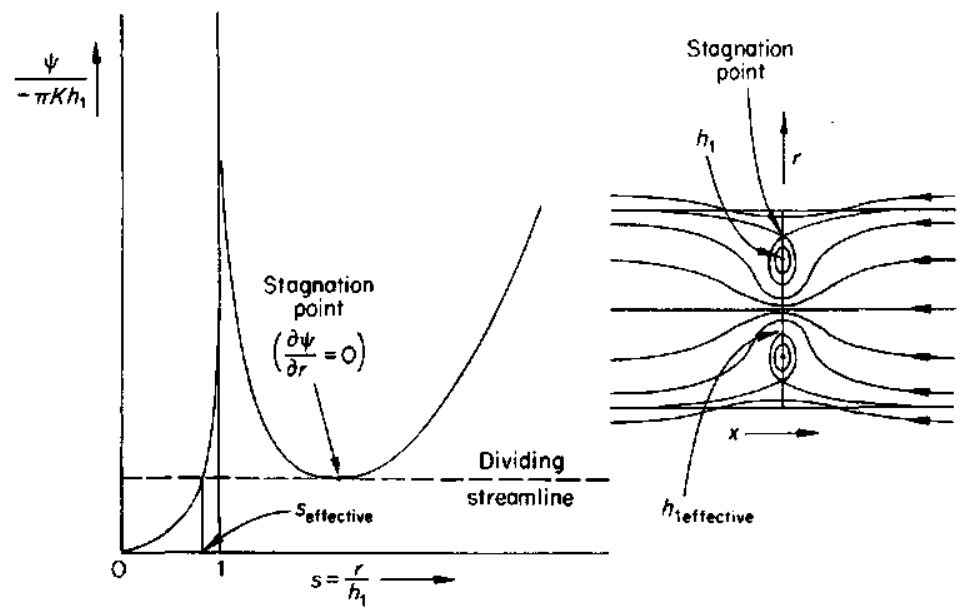

FIG. 7. A: stream function of the combination of a circular vortex filament and a parallel stream in the plane of the (moving) mouth aperture of a fish as a function of the normalized radius. The value of the dividing streamline is indicated on the ordinate. The value of the stream function is infinity at the vortex singularity. The minimum value of the stream function for $r>h$, indicates the stagnation point (the velocity there is zero). B: streamline pattern of the combination of the circular vortex filament and the parallel stream.

This is easy to derive from equation (24), because this stream function reduces for large $x$ to the stream function of a dipole. Substitute therefore in equation (24) $R=\sqrt{x^{2}+h_{1}^{2}}$ and equation (27). The result will be:

$$
\psi=\frac{\mu r^{2}}{R^{3}}
$$

which is the stream function of a dipole with strength $\mu$.

Combining the dipole with a parallel stream with strength $U$ (stream function $\psi=-\frac{1}{2} U r^{2}$ ) one gets a field of flow from which the dividing streamline approaches an asymptote for large $x$ (Fig. 5). The radius of this asymptote is:

$$
r_{\text {asymptote }}=\sqrt{3 \sqrt[3]{\frac{\mu^{2}}{U^{2}}}}
$$

Within the dividing streamline the water will flow into the mouth aperture of the fish. Water outside this streamline flows along the fish. An approximation of the "effective maximum radius" (see Fig. 7) of the mouth aperture may be derived by taking equal the volume flow of the dipole for large $x$ 
with the volume flow of the vortex filament for $x=0$ (here the mouth aperture).

Carrying out this calculation with $u_{m}=-a \cdot U,(a \geq 0$, for explanation see equation (35)) results in:

and:

$$
h_{1 \text { effective }}=h_{1} \sqrt{\frac{3 \sqrt[3]{a^{2} / 4}}{(a+1)}} \quad(a \geq 1)
$$

$$
\frac{r_{\text {asymptote }}}{h_{1 \text { effective }}}=\sqrt{(a+1)} \quad(a \geq 1) .
$$

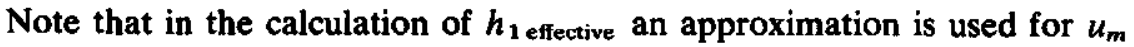
(equation (26)). In fact $u_{m}$ depends on $r$.

When $a=1\left(\rightarrow u_{m}=-U\right)$ the velocity of the fish due to suction is equal to the velocity of the water entering the mouth aperture. We find then $h_{1 \text { effective }} \approx 0 \cdot 97 . h_{1}$ and $r_{\text {asymptote }} \approx 1 \cdot 41 . h_{1}$ effective.

Formula (30) is not valid for values of $0 \leq a<1$. In that case it is impossible to express $h_{1 \text { effective }}$ with a simple formula and it is necessary to calculate the dividing streamline of the circular vortex filament accurately. This is done by expansion of equation (23) in the following series (cf. Abramowitz \& Segun, 1965):

$$
\psi=-2 K h_{1}\left[\frac{\left(s^{2}+1\right)}{(s+1)} \log \frac{(4 s+4)}{(s-1)}-(s+1)+\operatorname{order}\left[(s-1)^{2} \log \frac{1}{(s-1)}\right]\right] .
$$

(The normalized radius of the vortex filament $s=r / h_{1} \approx 1$ ). The stagnation points and thus $r_{\text {asymptote }}$ and $h_{1 \text { effective }}$ can be calculated if the stream functions of the vortex and of the parallel stream are added. Then the following formula is applied to find the stagnation points:

$$
-\frac{1}{r} \frac{\partial \psi}{\partial r}=0 .
$$

The calculation results for $a=1$ in $h_{1 \text { effective }} \approx 0.94 . h_{1}$ and $r_{\text {asymptote }} \approx$ $1 \cdot 74 . h_{1}$ effective. This demonstrates the validity of the application of equation (30) for $a=1$. For $a=0 h_{1 \text { effective }}$ and $r_{\text {asymptote }}$ converge to $h_{1}$.

For most pelagic fishes the parameter " $a$ " will be of order 1 . In this case only water in front of the mouth will be sucked. Then the error, which is made by taking in the calculations $h_{1}$ instead of $h_{1}$ effective will be some per cents.

The ratio of total height of the fish body and the mouth aperture may be found from equation (31) because then the fish is optimally streamlined. 


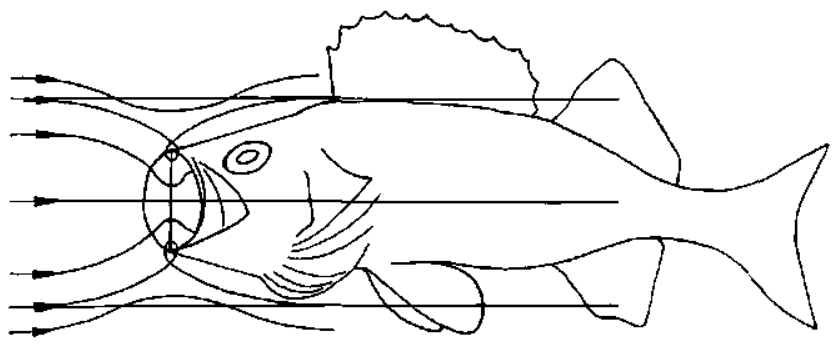

FIG. 8. Streamline pattern during suction feeding in a generalized teleost (Perca). If the streamline of the body is in accordance with the ratio between $u_{m}$ and $U$ (parameter $a$ ) a minimum pressure drag is obtained. The figure represents a value of " $a$ " of order 1 .

In this way a picture is obtained about a "generalized" fish profile (Fig. 8). In the above considerations about the combination of the vortex and parallel stream the origin of the frame is the centre of the mouth aperture of the fish. This frame moves with velocity $U$.

For pressure calculations, however, it is required to know the velocities of the water in an earth-bound frame. Therefore consider a circular vortex filament, moving with velocity $U$ in such a frame. The radius of the filament is $h_{1}$ and its positive position $x_{m}$. The velocity at $x_{m}$ is $u_{m}$.

The velocity of the water near a point of the $x$ axis is:

$$
u=\frac{u_{m} h_{1}^{3}}{\sqrt{\left\{\left(x-x_{m}\right)^{2}+h_{1}^{2}\right\}^{3}}} .
$$

This is easily derived from equations (25) and (26). Note that both $u_{m}, x_{m}$ and $h_{1}$ are functions of the time and $x$ is here the position abscissa in the earth-bound frame.

\section{(c) Coupling of velocities inside and outside the profile}

In order to couple the calculations in the earth-bound frame and in the frame, moving with the fish, we assumed as a first approximation that the ratio " $a$ " between the translation velocity of the circular vortex filament and the water velocity in its centre is constant during the suction act. This is expressed as follows:

$$
u_{m}=-a . U \quad(a \geq 0, \text { see section (b)) }
$$

If " $a$ " is small, the mass of the fish is small with respect to the moved mass of water and the forward motion of the fish due to suction will be great. We then get mainly a parallel stream in the mouth aperture. If " $a$ " is very large the fish is heavy with respect to the sucked water. It will 
As is apparent from the equation describing the pressure inside the moving and expanding or compressing profile (equation (43)) three mutually dependent parts can be distinguished. The first term describes the calculation of that part of the pressure as a whole due to flow of water in the expanding or compressing profile. The second and third terms add to this the pressures due to the forward movement of the expanding or compressing profile and the last two terms give the component of the pressure due to the external flow in front of the mouth. Note that each of the three components of the pressure is composed of a velocity pressure (Bernoulli) and an acceleration pressure.

\section{(c) Pressure calculation with open valve}

In order to calculate the pressure with open opercular and branchiostegal valves $(t \geq \tau)$ first the approximation will be considered, whereby the field of flow for $x \leq 0$ (behind the profile) will be bound by a cylindrical free streamline sheet. This being the situation the pressure at the opercular slits is equal to the environmental, hydrostatic pressure $p_{0}$. A sound hydrodynamical reason to suppose a pressure other than $p=p_{0}$ at the opercular slits does not exist in our opinion. When a slender (unidimensional) body moves through a frictionless fluid, thereby not disturbing this fluid, the pressure at its flanks is equal to the hydrostatic pressure. On the contrary, when such a body is placed in a stream the pressure causing the fluid to move is measured at its flanks. The equation of motion (7) becomes:

$$
-\frac{1}{\rho} \frac{\partial p}{\partial x}=\frac{\partial\left(u_{n}+U\right)}{\partial t}+\left(u_{n}+U\right) \frac{\partial\left(u_{n}+U\right)}{\partial x} .
$$

The calculation of the pressures will now include the following steps. First, integrate equation (44) using one of the two boundary pressures ( $p_{0}$ or $p_{m}$ ) at one of the openings of the profile. An equation in $g(x, t)$ (see equation (20)) will be the result.

Next determine $g(x, t)$ by substituting the remaining boundary pressure in the obtained pressure equation. The function $g(x, t)$ will then be determined by a first order, non linear differential equation and the pressure equation will then be fully known.

Several attempts to follow the above procedure were unsuccessful. One of the principal reasons most probably is that the two boundary conditions i.e. the pressures in $x=0$ and $x=l$ are defined at a very short distance of each other. This leads to instability as the following example may illustrate.

The pressure in the mouth aperture generally has a negative value because of the high velocities there during profile expansion. When the boundary condition prescribes the pressure at the opercular slits to be kept at a value 
$p_{0}$, there are forces, braking the flow towards $x=0$ and much later even generating positive velocities. In that case the model becomes instable and gives velocities and pressures tending to infinity. In order to avoid the above mentioned difficulties, we decided to derive the boundary conditions from the velocity. It was thereby stated, that after opening of the opercular valve the fish is unable to generate a considerable translating force by continuing profile expansion or compression. Therefore, for $t>\tau, U$ is a constant. Because of equations (35) and (36) $u_{1}$ has also a constant value.

In order to avoid discontinuities in the pressure, the opercular valve must open at an extreme value of the velocity $u_{1}$. This boundary condition is mentioned above (see equation (21)).

The values of $u_{n}$, defined by equations (19) and (22) are substituted in equation (43). The result is an analogue pressure equation in $u_{n}$ for $\Delta p_{n}(x, t)$. No values of the pressures in and outside the opercular valve, measured simultaneously at the time of its opening, are available.

It is considered highly probable however that the opening of the opercular valve is caused by a combination of direct muscle forces (evidence from EMG, see Osse, 1969) and indirect forces due to a positive internal pressure on the operculars.

These theoretical considerations gain some support from the observation in the movie pictures that polystyrene spheres in the flow (see Muller \& Osse, in preparation) show a jetlike diverging flow from the opercular slit (Fig. 9(a)). This flow can only be caused by a pressure in the jet exceeding the value of the ambient pressure.

\section{(E) DISCRETIZATION PROCEDURE}

The functions $h(x, t), u(x, t)$ and $\Delta p(x, t)$ are functions of position and time.

To make them available for computer simulation, they must be mapped on two-dimensional arrays with position points $x_{i}$ and time points $t_{i}$. As differentiation in time was applied a high number of $t_{i}$ points was required to obtain the necessary accuracy.

A solution to obtain this high number of time points which also saved memory space was to split up the time axis in a hundred intervals and to carry out the calculation for each successive interval. For the same reason a combination of calculations was preferred at every available opportunity, e.g. $u_{v}$ was directly calculated from $h$, without storing information in arrays.

The difference formulae, which have been used are (Stiefel, 1961):

$$
f^{\prime}(t) \equiv[f(t+\Delta t)-f(t-\Delta t)] / 2 \Delta t,
$$


$\Xi$

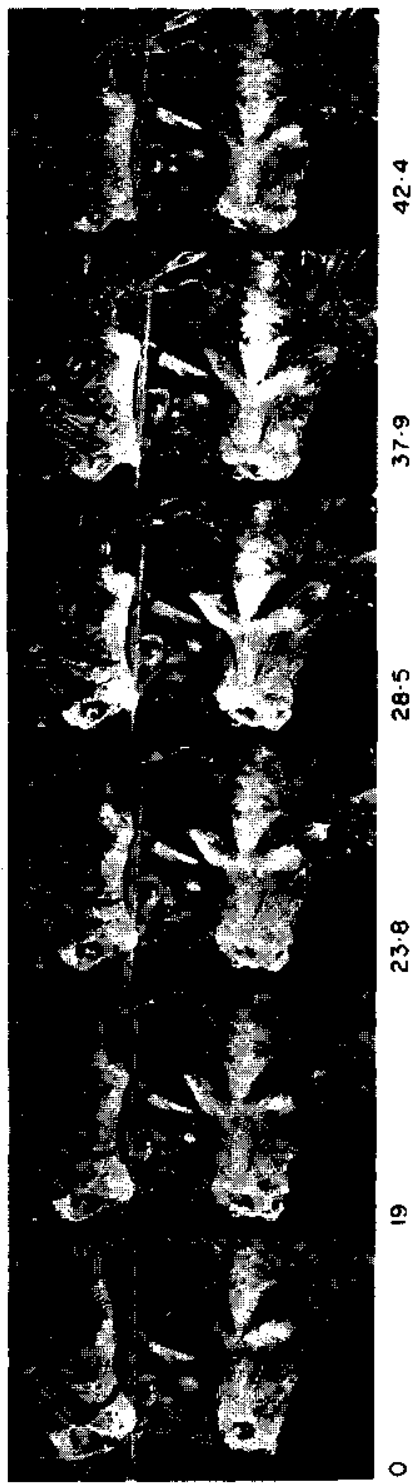

$\underline{m}$
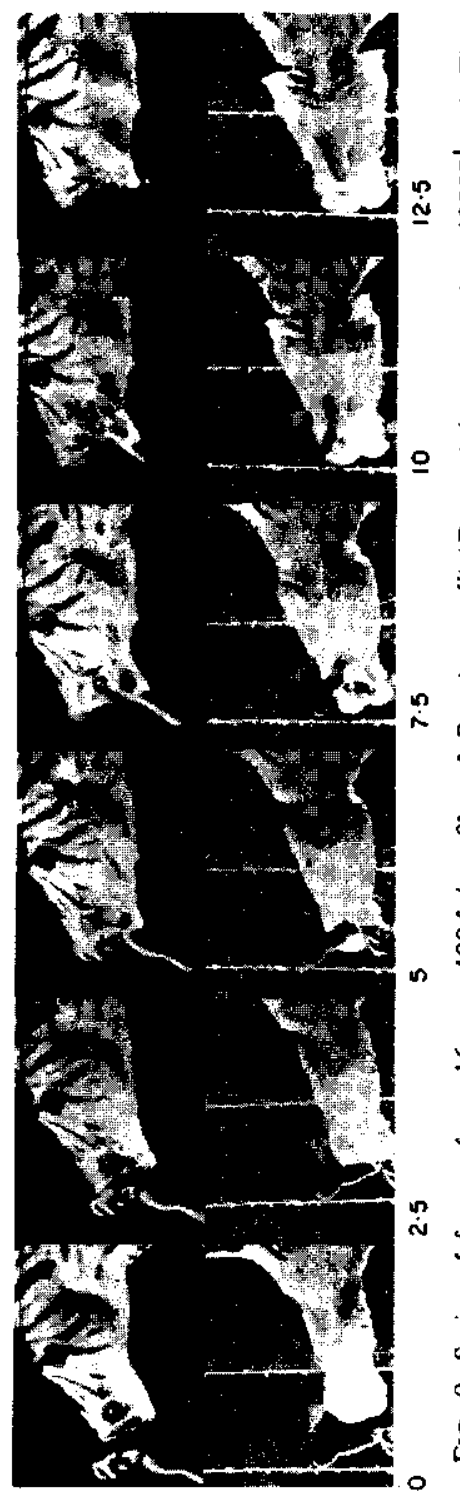

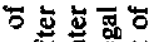

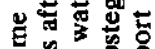

点哭总 它 遇 i。 8 \% 年

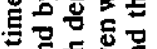

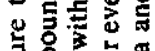
要边

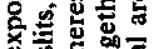

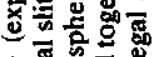
亏 议 는 包究视 三

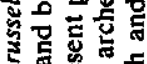
政 홍

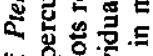
등용. 통호을

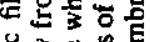

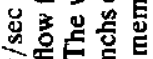

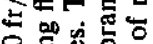
号要焉 हีํㅝㄹ 安送 割

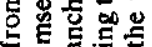
.5 政它

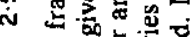
。象总 \& 氖焉总志 人雪

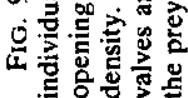


in the centre of the array and

$$
f^{\prime}(t) \equiv[-3 f(t)+4 f(t+\Delta t)-f(t+2 \Delta t)] / 2 \Delta t,
$$

for the left side of the array and

$$
f^{\prime}(t)=[3 f(t)-4 f(t-\Delta t)+f(t-2 \Delta t)] / 2 \Delta t,
$$

for the right side of the array. Integration was carried out with:

$$
\int_{x_{1}}^{x_{n_{1}}} f(x) \mathrm{d} x \equiv \sum_{i=2}^{n_{1}} \frac{1}{2} \cdot \Delta x \cdot\left[f\left(x_{i-1}\right)+f\left(x_{i}\right)\right] .
$$

Non-linear differential equations of the first order were solved by defining the initial value of a function $f(t)$ in the point $t_{i}$, calculation of the slope of $f(t)$ in $t_{i}$ and calculation of $f\left(t_{i}+\Delta t\right)$. Repetition of this process for each interval produced $f(t)$. The accuracy of all the above calculations was of order $(\Delta t)^{2}$ and $(\Delta x)^{2}$. To determine the required time and space steps, simulation runs were carried out with different array sizes of the functions involved. For second power convergence the contraction formula of Banach (Kuipers \& Timman, 1972) must be satisfied:

$$
d\left(y_{n}, \xi\right) \leq \frac{\Theta^{n}}{(1-\Theta)} d\left(A^{*} y_{0}, y_{0}\right) \quad(0<\Theta \leq 1) .
$$

The application of this formula is elucidated using the following scheme:

\begin{tabular}{cccccl}
\hline Number of time points $\rightarrow$ & $n_{2}$ & $2 n_{2}$ & $4 n_{2}$ & \\
\hline Number of position points & & & & & \\
$\downarrow$ & & & & & \\
$n_{1}$ & $y_{0,0}$ & $y_{0,1}$ & $y_{0,2}$ & $\rightarrow$ & Limit value $y_{0, \infty}$ \\
$2 n_{1}$ & $y_{1,0}$ & $y_{1,1}$ & $y_{1,2}$ & $\rightarrow$ & Limit value $y_{1, \infty}$ \\
$4 n_{1}$ & $y_{2,0}$ & $y_{2,1}$ & $y_{2,2}$ & $\rightarrow$ & Limit value $y_{2, \infty}$ \\
& $\downarrow$ & $\downarrow$ & $\downarrow$ & & $\downarrow$ \\
& Limit & Limit & Limit & $\rightarrow$ & Limit of limit \\
& value & value & value & & values $y_{\infty, \infty}$ \\
& $y_{\infty, 0}$ & $y_{\infty, 1}$ & $y_{\infty, 2}$ & $=$ Analytical solution $\xi$ \\
\hline
\end{tabular}

Let the numerical solutions of a certain problem be $y$ and the analytical solution $\xi$. The distance between $y$ and $\xi$ after $n$ operations $A^{*}$ (e.g. enlargement of the number of array points $n_{1}$ or $n_{2}$ ) is given by equation (49). However the system parameter $\Theta$ is generally unknown. This parameter can be estimated by comparing the successive calculated values $y_{0}$, $y_{1}, \ldots, y_{n}$. 
These values approximate the limit value of $y$ after $n$ operations $A^{*}$. The limit values of $y$ in the two directions of enlargement of respectively $n_{1}$ and $n_{2}$ converge in respectively the $n_{2}$ and $n_{1}$ direction to $\xi$. When in such a way an estimation of $\xi$ has been made, it is possible to specify accurately the process error for a calculation with chosen $n_{1}$ and $n_{2}$.

The steps of time and space must be taken small enough to obtain a sufficiently accurate numerical solution. On the other hand they may not be chosen too small, because of the fact that noise will be generated (Fig. 10). In order to avoid this and in order to keep the processing time

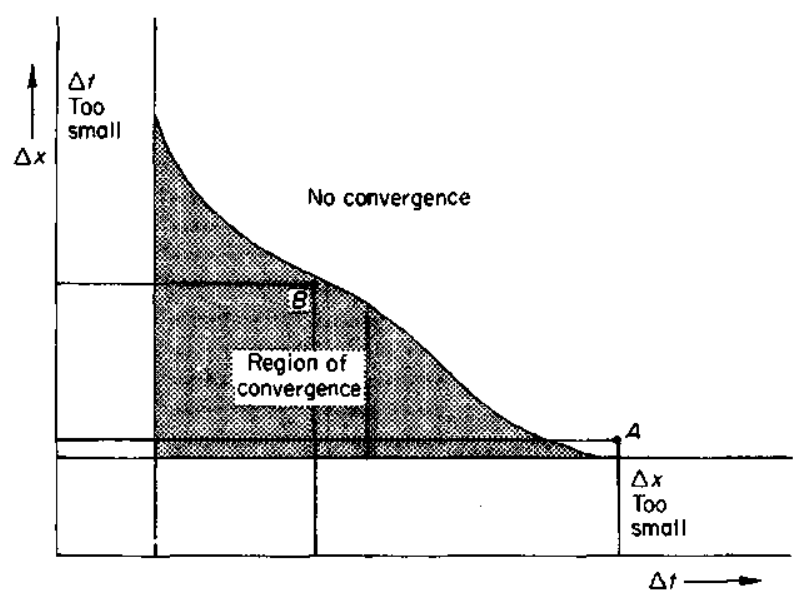

FIG. 10. Region of convergence of the numerical approximation of functions which are dependent on time and position. Only for a limited range of pairs of the time steps $\Delta t$ and the space steps $\Delta x$ a valid approximation of the involved functions is attained. The point $A$ falls outside the region of convergence although the space step $\Delta x$ is sufficiently small. The point $B$ falls in the region of convergence although not very small values of $\Delta t$ and $\Delta x$ are chosen. Taking too small time and space steps will result in the generation of noise. To keep the calculations accurate and as short as possible, time and space steps must be preferentialiy chosen close to point $B$.

to a minimum, we finally accepted a process error of less than $2 \%$. To avoid errors in the calculation of peaks we used the rule, that peak values did only exist if formed by at least five points. Similarly at values close to $t=0$ we avoided too acute angles in the approximation of such a limit value.

The program required finally seven calculation-arrays of $[40,1000]$ points. The required memory space was about $54 \mathrm{~K}$ words and the processing time round 1 min. 


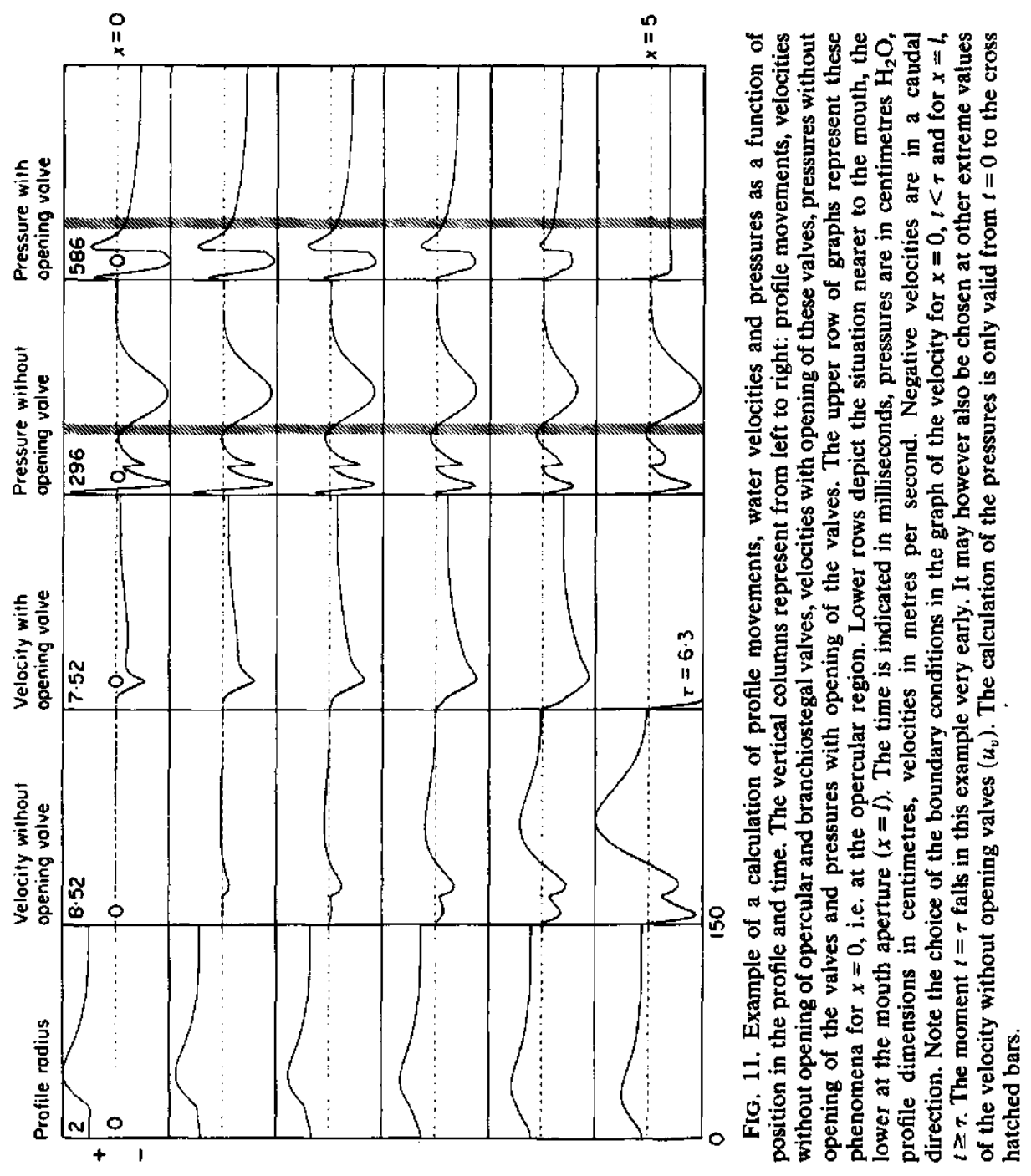




\section{Discussion}

The biological results of the model study are extensively described in (Muller \& Osse, in preparation). Therefore here only some remarks on the applicability of the model will be given.

The model allows the calculation of the time courses of pressures and velocities of the water during a fast dictated profile expansion and compression of a rotational symmetric fish profile (Fig. 11). This provides insight in the physics of suction, i.e. the understanding of the sequence of events in time and place in quantitative terms occurring during prey capture in fish.

We considered this knowledge an essential prerequisite to generate hypotheses on the biological meaning of fish head structures as adaptations for suction feeding. Comparison of in vivo measurements of fish movements, water velocities and pressures with model results provided checks on our model approach of fish suction feeding. In this way the model has been tested and adjusted according to experiences.

The relation between chosen movement and calculated velocity and pressure gives insight in the ways in which the profile is able to move. By defining a criterion either for the velocity or for the pressure or for both, one finds for a certain profile a rather narrow range of possible movements. The amplitudes of movements, the phase relations between movements of profile parts, profile velocities and profile proportions are factors in a complex process and they therefore may not be chosen independently of each other. Most combinations of these variables lead to absurd water velocities or pressures.

Thus, by variation of dimensions or velocities of the profile one may formulate (applying a certain insensitive criterion of water velocity or pressure) converging demands to which the profile is subjected. The following example shows this.

Figure 12 gives the peak pressure in the opercular region as a function of the profile-length if all other parameters are hold constant. From the strong increase of the pressure, we conclude that the profile construction near the opercula can be expected to be more ruggedized with increasing profile-length. The other possible conclusion is that only length increase without changes in other parameters is impossible. The architecture of a fish head is thus subjected to size, strength and velocity criteria derived from the feeding function. In the pipefishes we found indeed a correlation between increased snout-length and rigidity of the gill cover when a series of species is compared (Osse \& Muller, 1980). The time span between start and the moment $t=\tau$, when the opercular valve opens, defines different types of suction. For small $\tau$ a type of suction is obtained, characterized 


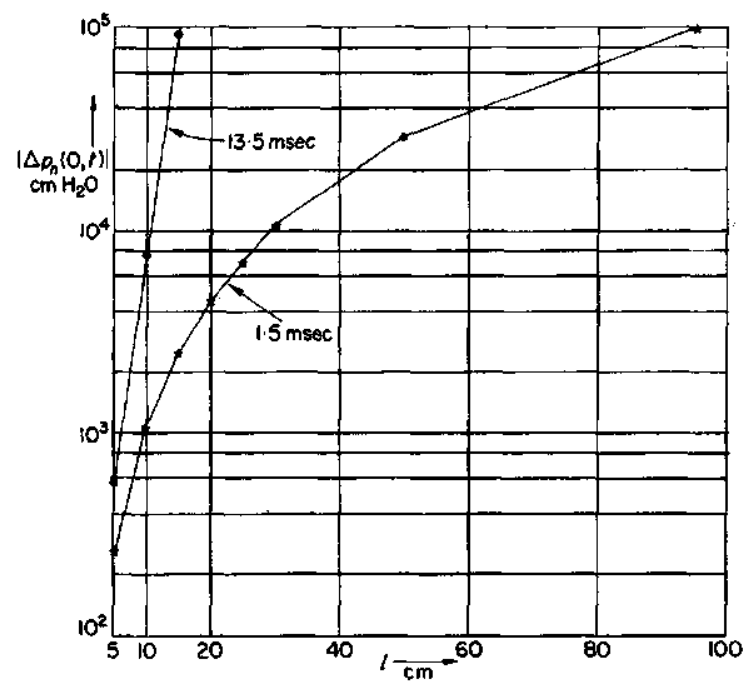

FIG. 12. Model simulation of the influence of increase of profile length on pressure. Other form and movement parameters are held constant. The time courses of the profile movements, water velocities and pressures of the profile with length $I=5 \mathrm{~cm}$ are represented in Fig. 11 . The largest values of negative $\left(C_{-}\right)$) and positive ( $\left.-\downarrow\right)$ pressures are drawn. The arrows indicate the moments when the pressures occur. Note the extreme increase in pressure with increasing profile length. This indicates that only a narrow range of profile lengths is possible in nature with a chosen set of form and movement parameters.

by giving only a small impulse to the water. We call this "velocity suction". When $\tau$ is large, the mouth and opercular cavities first fill with water before the opercular valve is opened. This we call "volume suction". These are qualitative extremes in a continuous series of options. Both types of suction do imply different constructional demands for the fish-head. In the trout velocity suction is observed, the main abduction of the operculars takes place with open valves while in the cod an enormous volume increase of the opercular cavities occurs with the valves still closed (Muller \& Osse, in preparation).

Another application of the model is to extrapolate from the dimensions of dead or fossil material the range of maximal movements of the fish head and therefore the probable suction process as a whole. In this way, the evolution of fish systems for suction feeding may be studied.

The present study provides a first quantitative approximation for the highly complex problem of the unsteady flow during suction feeding connecting events in buccal and opercular cavities and the flow in front of the mouth aperture in one continuous approach. Several problems however need further attention, e.g. the boundary condition problem for pressure 
and velocity. The influence of the prey on the flow has not been included, neither the distance from which a prey can be sucked. This important problem is dealt with by Weihs (1980). In his view the forward motion of the predator enhances the chance that a prey is caught. However, this is only valid when the ratio between sink strength and forward motion is of order 1 . When the forward motion is high relative to the sink strength only water near the axis will be ingested. Therefore a distinction must be made between translation of the fish by sucking itself forward and translation movements generated by fins, body and tail. In the first case no stagnation point will be formed at the snout tip, in the latter this may occur. This approach is described in Muller \& Osse (in preparation).

Furthermore Weihs assumes a constant rate of water intake and permanently closed opercular valves. As explained above this is not a valid approach. Only after initial suction and the opening of the opercular valves a constant flow rate can be expected. In that case, however, the total volume sucked is greatly increased.

In the model presented here the role of the gills in the flow pattern is not taken into account (see Lauder, 1980a, $b$ ). Arguments for the latter view originate from movie studies. The hemibranchs belonging to one arch are always seen folded together, e.g. through the transparent mouth bottom when the opercular is still closed in Pterois (Fig. 9(b)). Lauder (1980a) explains the difference between buccal and opercular pressure (respectively -650 and $-150 \mathrm{~cm} \mathrm{H}_{2} \mathrm{O}$ in Lepomis) by the presence of a high resistance formed by the gills (p. 177). This explanation is obtained by comparing buccal and opercular pressure curves in successive time intervals (see page 50). The present model approach explains the occurring differences between buccal and opercular pressures directly from the unsteady flow without having to assume a high resistance of the gills.

The nearly steady flow over the gills during respiration in fish is maintained by differences in pressure of circa $1 \mathrm{~cm} \mathrm{H}_{2} \mathrm{O}$ between buccal and opercular cavities (Ballintijn, 1968). The gill filaments of adjacent arches apparently do not form a high resistance to the flow over the gills, otherwise this pressure difference would not produce any flow. Besides a low gill resistance reduces the energy needed for the respiratory pump and can therefore be expected.

Lauder $(1980 b)$ writes on p. 66: "Opercular cavity pressures generally average one-fifth the buccal pressures due to the high gill resistance which functionally segregates the mouth cavity". This would mean that a pressure difference of $500 \mathrm{~cm} \mathrm{H}_{2} \mathrm{O}$ could be obtained due to the high gill resistance. It is in our view inconceivable that such a wide range of resistance can be achieved in the gills. Besides, the adaptive significance of such a sudden 
high gill resistance in the middle of a suction feeding act, limiting the amount of sucked water by obstructing the flow to the opercular cavities seems to be absent.

The role of suction feeding in the determination of form requirements in a fish-head is important in our view. This does not exclude considerable influence of other functions (respiration, streamlining, camouflage, etc.) on this form. Therefore we now apply the model on a variety of Teleostei. Both the variation in profile movement and the implications of the hydrodynamical demands to the head-construction are analysed.

We wish to thank Ir. K. D. Maiwald (Delft Hydraulics Laboratory) for his help with the numerical problems and the valuable discussions. Much of the writing of this manuscript was supported by a grant from the Netherlands Organization of Pure Research (Z.W.O.), obtained through BION (Biological Research in the Netherlands).

\section{Nomenclature}

$A=A(x, t)=\pi h^{2}(x, t)$ area of transverse section of profile

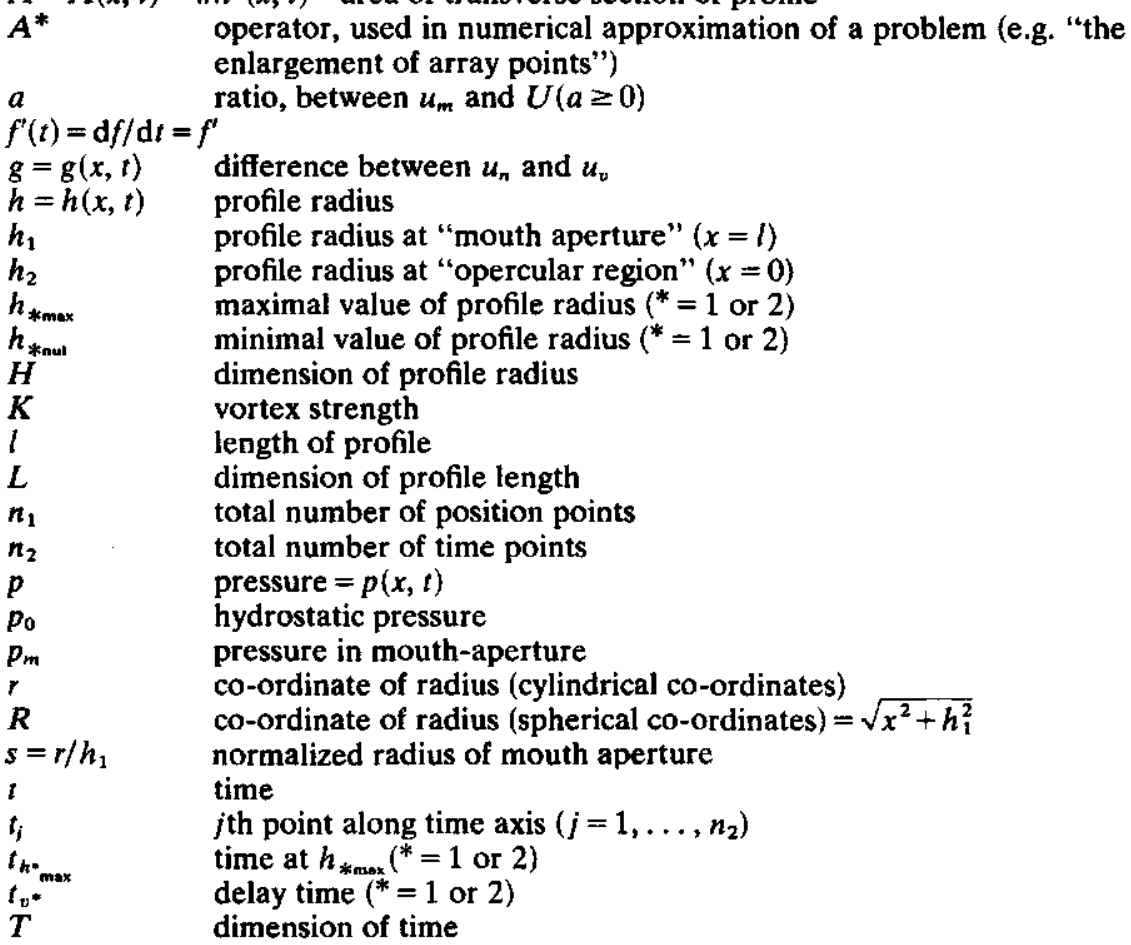




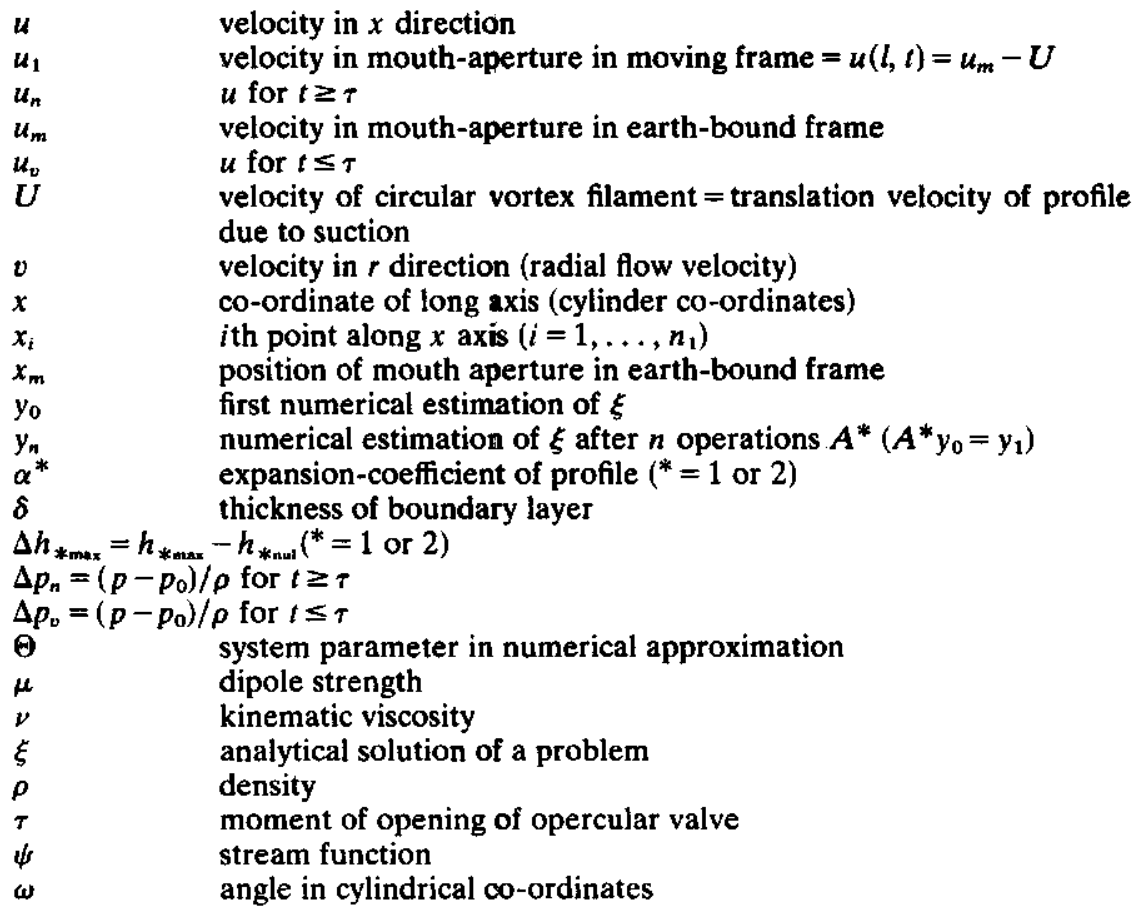

\section{REFERENCES}

Abramowitz, M. \& SEgun, 1. A. (1965). Handbook of Mathematical Functions. New York: Dover.

ALEXANDER, R. McN. (1967a). Functional Design in Fishes. Hutchinson: London.

ALEXANDER, R. McN. (1967b). J. Zool. Lond. 151, 43.

BaLlintuN, C. M. (1968). The respiratory pumping mechanism of the carp Cyprinus carpio (L). Thesis. RU Groningen, The Netherlands.

Elshoud-Oldenhave, M. J. W. \& Osse J. W. M. (1976). J. Morph. 150, 399.

GANS, C. (1969). Copeia 4, 855.

KUIPERS, L. \& TIMMAN, R. (1972). Handboek der Wiskunde deel 3. Haarlem: Scheltema en Holkema.

LAUDER, G. V. (1980a). Hydrodynamics of prey capture by teleost fishes. Proceedings of the Second Conference on Bio-Fluid Mechanics. New York: Plenum Press.

LAUDER, G. V. $(1980 b)$. J. exp. Biol. 88, 49.

MiLNe-Thomson, L. M. (1968). Theoretical hydrodynamics. 5th edition, London: MacMillan.

MulleR, M. \& OSSE, J. W. M. (1978). Structural adaptations to suction feeding in fish. Proc. Zodiac-symp. "On Adaptation", pp. 57-60, Wageningen: Pudoc.

Muller, M. \& OSSE, J. W. M. (in preparation). Hydrodynamics of suction feeding in fish. OSSE, J. W. M. (1969). Neth. J. of Zool. 19, 289.

OSSE, J. W. M. \& MULLER, M. (1980). A model of suction feeding in teleostean fishes with some implications for ventilation. In: Environmental Physiology of Fishes (M. A. Ali, ed.) NATO ASI. Series A. Life Sciences. 
Pietsch, Th. W. (1978). Copeia 2, 255.

STIEFEL, E. (1961). Einführung in die Numerische Mathematik. Stuttgart: Teubner Verlag. WEIHS, D. (1980). J. Fish Biol. 16, 425.

\section{APPENDIX}

Formulas of cylinder model (conditions: see general formulas)

$$
\begin{gathered}
h(t)=h_{\mathrm{nul}}+\left(h_{\max }-h_{\mathrm{nul}}\right) \cdot\left[\frac{t}{t_{h_{\max }}} \cdot \exp \left\{1-\frac{t}{t_{h_{\max }}}\right\}\right]^{\alpha,} \text { and }(11) \text { from equations } \\
A(t)=\pi \cdot h^{2}(t), \text { from equation (10) } \\
u_{v}(x, t)=-\frac{A^{\prime}}{A} x, \text { from equation (18) } \\
u_{n}(x, t)=-\frac{A^{\prime}}{A} x-\left[\frac{A^{\prime}(\tau)}{A(\tau)}-\frac{A^{\prime}}{A}\right] \cdot l, \text { from equations (19) and (22) } \\
\frac{\Delta p_{v}(x, t)}{\rho}=\left[\frac{A^{\prime}}{A}\right]^{\prime}\left[\frac{1}{2} x^{2}-\frac{x l}{(a+1)}-\frac{l^{2}}{2} \frac{(a-1)}{(a+1)}\right] \\
+\left[\frac{A^{\prime}}{A}\right]^{2}\left[-\frac{1}{2} x^{2}+\frac{x l}{(a+1)}-\frac{l^{2}}{2} \frac{(2 a+1)}{(a+1)^{2}}\right]-\frac{2 a l h^{\prime \prime}}{(a+1)}
\end{gathered}
$$

from equation (43). 


\section{DANKWOORD}

Een proefschrift heeft vaak het karakter van een wetenschappelijke verheerlijking van één persoon. Was het vroeger wellicht het geval, dat een onderzoek werkelijk door één persoon werd gedaan, tegenwoordig komt een dergelijk werk tot stand door samenwerking van veel mensen. De mensen, die aan dit werk hebben bijgedragen, wil ik hier graag bedanken.

- In de eerste plaats wil ik mijn ouders bedanken voor de gelegenheid, die ze mij hebben geboden om deze opleiding te volgen en voor de steun, die ik van hen heb ontvangen.

- Jan Osse, een promotor heeft het niet gemakkelijk als hij zo'n eigenwijze en ongemakkelijke klant in huis haalt. Ik wil je hierbij bedanken voor de initiëring van dit werk, voor de lessen in de morfologie en voor de stimulerende invloed, die van je is uitgegaan.

- Jan Verhagen, alle keren, dat ik bij je langs kwam om advies over hydrodynamische problemen, voelde ik mij een leerling, die zijn huiswerk slecht had gemaakt. Ik beschouw het als een eer, dat je mijn co-promotor wilt zijn. Als dank zou ik je willen adviseren om iets minder bescheiden te worden!

- Johan van Leeuwen, kameraad en mede-oprichter van de sub-sektie: "Hydrodynamics...". Op een biologisch lab is een biofysikus toch wel een beetje eenzaam. Door jouw aanwezigheid heb ik me niet als een gastarbeider met taalproblemen hoeven voelen. I thank you very much!

- Klaus Maiwald, sommige mensen zijn huiverig voor numerieke wiskunde. Ik nu ook! Je hebt me niet alleen om de voetangels en klemmen van de numerieke benadering heen geleid, maar ook nog programmeren geleerd. Voor het eerste ben ik je dankbaar, voor het tweede weet ik het nog niet...

- Maarten Drost, in feite was jouw doktoraal-onderwerp toch iets té simpel. Daarom ben ik blij, dat je voor je promotie-onderzoek het moeilijkste onderwerp hebt gekregen! Wie " $a$ " zegt, moet ook "-(-b)" zeggen. Ik wil je bedanken voor de fijne samenwerking.

- Arie Terlouw, Ben van Schie en Albert Ramakers wil ik bedanken voor hun technische assistentie en voor de prettige samenwerking.

- Gert van Eck, met bewondering heb ik gezien hoe jij micro-problemen tot MACRO-problemen reduceert. Al was jouw raad bij mij niet aan het verkeerde adres, toch heb ik wel eens last gehad van buffer-overflow.

$\square \#$ BDN\$KT; bedankt!

- Wim Valen maakte op deskundige wijze vele foto's en moeilijke tekeningen (hoewel ik mijn eigen visje tóch mooier vind!).

- Naast de mensen, die ik hier persoonlijk heb bedankt, wil ik mijn kollega's van de vakgroep Experimentele Diermorfologie en Celbiologie, i.h.b. van de sektie Morfologie, bedanken voor hun samenwerking en vriendschap, voor de bescherming, die ik tijdens mijn onderzoek op administratief terrein heb genoten, voor het vertrouwen in mij m.b.t. het onderwijs en voor het geduld m.b.t. 
mijn promotie. Verder wil ik hen erop wijzen, dat sommige gerookte Pro-acanthopterygii (e.g. Salmo) aanzienlijk smakelijker zijn dan dito cypriniden. Deze laatste groep vissen is overigens met de beste wil van de wereld niet eetbaar te maken! 


\section{CURRICULUM VITAE}

Mees Muller werd op 27 augustus 1948 geboren in 's Gravenhage. Na een boeiende periode van Montessori- en gewoon lager onderwijs te Voorburg en Delft, meldden zijn ouders hem hoopvol aan bij het Grotius-Gymnasium te Delft. Helaas was de studie der klassieken niet voor hem weggelegd en na een solide onderbouw deed hij in 1968 eindexamen HBS-B aan de Thorbecke-HBS te Zwolle.

Het Ministerie van Defensie was zo vriendelijk om Mees af te keuren voor de Militaire Dienst. Voor deze ontwapenende geste betuig ik deze instelling mijn hartelijke dank!

Vanaf 1968-1974 heb ik Biologie gestudeerd aan de Rijksuniversiteit te Groningen. Het kandidaatsexamen, richting B1, Zoologie (W-N-S) behaalde ik "met genoegen". Daarna namen Prof. Dr. J.W. Kuiper en zijn medewerkers mijn opleiding in de Biofysika ter hand. Op het Natuurkundig Lab. heb ik leren begrijpen, waarom ik de Biologie zonder de steun van de Fysika zo'n ongrijpbare wetenschap vond. Tijdens mijn, zeer prettige, doktoraalperiode heb ik, naast het hoofdvak Biofysika, tevens de bijvakken: Hoofdstukken uit de Wiskunde en Elektrofysiologie gedaan.

Daarnaast heb ik nog diverse kursussen gelopen, o.a. Elektronen-mikroskopie, Instrumentmaken, Mariene Biologie, Systematiek van Lichenen en Elektrofysiologie. Op 26-nov-1974 studeerde ik "cum laude" af.

$\mathrm{Na}$ de universiteit ging ik naar de hogeschool, teneinde het hier beschreven onderzoek uit te voeren, hetgeen o.m. in dit proefschrift resulteerde. Prof. Dr. J.W.M. Osse heeft mij met kunst en vliegwerk in dienst van diverse instanties kunnen houden: eerst de LH (1/2 j.; vanaf begin 1975), daarna ZWO ( 1 j.), overgenomen door BION (3 j.; afgesloten eind 1979) en daarna wéer de LH (nu ca. $3 \mathrm{j}$.). Op dit moment ben ik in dienst bij de LH als wetenschappelijk medewerker voor de helft van de tijd.

Naast mijn wetenschappelijke aktiviteiten heb ik mij intensief bezig gehouden met muziek en (volks-)dans. Ik ben verslaafd aan muziek; heb 17 jaar piano gespeeld, waarbij vooral de lessen van P. Berman een diepe indruk op mij hebben gemaakt.

Tien jaar geleden ben ik overgestapt op de Macedonische en Bulgaarse muziek. i.h.b. de doedelzak uit die streken, de "gajda". Begrip van deze muziek, de volksaard en kultuur van dit gebied heb ik mij o.a. kunnen verwerven door kennis van de Macedonische en, in mindere mate, de Bulgaarse taal.

Mees Muller.

Hackettweg 45, 6871KP Renkum. 